\title{
Design, favela e ativismos: experiências e aprendizados com a Redes da Maré no Rio de Janeiro
}

BRUNA FERREIRA MONTUORI

SÃO PAULO

2018 

UNIVERSIDADE DE SÃO PAULO

FACULDADE DE ARQUITETURA E URBANISMO

PROGRAMA DE PÓS-GRADUAÇÃO EM ARQUITETURA E URBANISMO

Design, favela e ativismos: experiências e aprendizados com a Redes da Maré no

Rio de Janeiro

\section{BRUNA FERREIRA MONTUORI}

SÃO PAULO | 2018 

BRUNA FERREIRA MONTUORI

\section{Design, favela e ativismos: experiências e aprendizados com a Redes da Maré no Rio de Janeiro}

VERSÃO ORIGINAL

Dissertação apresentada à Faculdade de Arquitetura

e Urbanismo da Universidade de São Paulo, como requisito parcial para obtenção do grau de Mestre em Ciências, pelo programa de Arquitetura e Urbanismo.

Área de Concentração: Design e Arquitetura

Orientadora: Professora Dra. Maria Cecilia Loschiavo dos Santos

Exemplar revisado e alterado em relação à versão original, sob responsabilidade da autora e anuência da orientadora. A versão original, em formato digital, ficará arquivada na Biblioteca da Faculdade.

São Paulo, 21 de maio de 2018 
Autorizo a reprodução e divulgação total ou parcial deste trabalho, por qualquer meio convencional ou eletrônico, para fins de estudo e pesquisa, desde que citada a fonte.

E-mail da autora: brumontuori@gmail.com

Esta pesquisa contou com o auxílio da FAPESP - Fundação de Amparo à Pesquisa do Estado de São Paulo | Processo No: 2016/16585-6

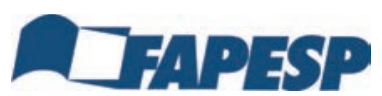

Créditos adicionais:

Acervo fotográfico: Douglas Lopes

Edição e tratamento de imagens: Romullo Fontenelle

Base cartográfica: Camila Aquino

Projeto gráfico: Bruna Montuori

Revisão textual: Tiago Abe

Catalogação na Publicação | Serviço Técnico de Biblioteca

Faculdade de Arquitetura e Urbanismo da Universidade de São Paulo

Montuori, Bruna Ferreira

Design, favela e ativismos: experiências e aprendizados com a Redes da Maré no Rio de Janeiro/ Bruna Ferreira Montuori; orientadora Maria Cecilia Loschiado dos Santos. - São Paulo, 2018. $236 \mathrm{p}$.

Dissertação (Mestrado) - Faculdade de Arquitetura e Urbanismo da Universidade de São Paulo. Área de concentração: Design e Arquitetura

1. Design. 2. Colaboração. 3. Rio de Janeiro. 4. Favela. 5. Ativismo. I. Santos, Maria Cecilia Loschiado dos, orient. II. Título. 
Só se pode chegar a um design verdadeiro quando se identificar a cultura brasileira. $O$ conceito de desenvolvimento só faz sentido se visto dentro da cultura.

Aloisio Magalhães, 1978 



\section{Agradecimentos}

Apesar desta dissertação sair das mãos de uma única autora, esse trabalho só pode ser realizado graças ao empenho de muitas pessoas que acreditaram no potencial dessa pesquisa e no encontro do design com a Maré. Por isso, gostaria de agradecer a todos que de alguma forma disponibilizaram o seu tempo, atenção e cuidado e contribuíram neste processo de aprendizado tão enriquecedor.

À minha orientadora Maria Cecilia Loschiavo dos Santos, por sempre abrir portas e acreditar em uma prática de fazer design mais humana e democrática, além do seu apoio, conselhos, conversas e confiança durante toda a pesquisa. Agradeço pelas lutas diárias dentro e fora de sala de aula, seu carinho e atenção em minha trajetória como pesquisadora.

À Fundação de Amparo à Pesquisa do Estado de São Paulo (FAPESP) pelo suporte ao longo do trabalho, incluindo seu apoio para participar de uma conferência internacional durante o ano de 2017. Ao Programa de Apoio à Pós-Graduação da CAPES que também viabilizou esta oportunidade única. À Faculdade de Arquitetura e Urbanismo da Universidade de São Paulo que abriu suas portas para minha pesquisa e a Maré e permitiu que essa rica ponte entre São Paulo e Rio de Janeiro fosse estabelecida.

Ao professor, amigo e parceiro de trabalho Marcos L. Rosa por toda cumplicidade, apoio total durante a pesquisa, orientações e a transferência contínua de conhecimento que só trouxeram excelência ao meu trabalho e me permitiram amadurecer como pesquisadora e profissional. Agradeço pela oportunidade de trabalharmos juntos, a me apresentar a uma forma de fazer cidade que eu nunca imaginei possível e a confiança em mim desde o nosso trabalho no DBUAA.

À professora Zoy Anastassakis por ter me estimulado a realizar esta pesquisa de mestrado no momento que eu mais precisava e por ter me introduzido a antropologia, 
área de pesquisa que me apaixono cada vez mais. Agradeço por todas as conversas, orientações e ensinamentos, além do cuidado e abertura no LaDA/ESDI/UERJ como espaço de apoio e troca.

A Geisa Lino, por sua parceria, amizade e disponibilidade durante toda a pesquisa de mestrado, por ter me recebido de braços abertos e ter confiado em mim. Agradeço pelas conversas, os aprendizados e risadas, por me dar autonomia no seu cotidiano de trabalho e se abrir para aprender comigo e com o design. Sempre admirarei a sua energia, força e garra que fazem o seu trabalho ser único no Complexo da Maré.

A Douglas Lopes, por seu carinho, amizade e confiança, por ter me ensinado tanto sobre a Maré e ter se engajado no trabalho desde o início. Agradeço por todas as trocas, conversas, aprendizados, encontros e risadas, pelos cafezinhos, passeios de bicicleta em busca de materiais inusitados e toda a mão na massa na Maré. Sem dúvida é um exímio designer e fotógrafo e graças a isso esta dissertação tem fotografias tão especiais.

A Alberto Aleixo, pelas conversas e histórias, pelo carinho e gentileza, sua abertura e disponibilidade. Sou uma grande admiradora do seu trabalho e mesmo os poucos momentos em que estivemos juntos foram de grande aprendizado.

A toda Redes da Maré e seus colaboradores que sempre me receberam com carinho e atenção durante a realização do trabalho: Mariane Rodrigues, Yuri Lobo, Marcos Diniz, Luanna Senna, Paulinho, Roberto França, Inês Salles, Daniel Remlik, Rodrigo Maré, Carlos Marra, Henrique Gomes, Maurício e Gabriela Lino. Aos parceiros externos à Redes, porém sempre presentes: a equipe do Muda Maré, Renan Braga, todos os participantes da oficina de marcenaria, a equipe do galpão Bela Maré, Gilberto Vieira e Clara Sacco do Data Labe. À Eliana Sousa Silva que, embora tenhamos nos comunicado pouco, foi uma pessoa que me permitiu compreender a Maré por outras lentes e aprender muito com o território. Sua contribuição ainda que a distância foi imprescindível.

Ao amigo e parceiro de oficinas Vinicius Mesquita, por todas as trocas e aprendizados, pela disponibilidade e carinho no desenvolvimento de atividades na Maré. Agradeço por toda a confiança e dedicação a este trabalho com o mesmo espírito "puquiano" mesmo depois de formados. 
Aos professores que colaboraram nesta jornada por meio de conversas, conselhos e orientações, sou extremamente grata pela sua disponibilidade e atenção: José Luiz Mendes Ripper, Rosana Vasques, Chiara Del Gaudio, Tatiana Salkurai, Marcos da Costa Braga, Bárbara Szaniecki, Jorge Langone, Luiza Novaes, Cid Antunes e Joy Till.

Às amigas e parceiras de pesquisa Viviane Nicoletti e Ana Julia Melo por todos os estudos, conversas e cumplicidade. Agradeço por todos os nossos encontros, discussões e aprendizados, as denúncias ao patriarcado e a luta por um design que nos representa. São em mulheres, pesquisadoras e profissionais como vocês que eu me inspiro todos os dias.

Aos amigos Marina Harkot, Gabriel Figueiredo e Paula Hori por todas as depressões coletivas e reclamações que tanto me ajudaram a superar os momentos difíceis da pesquisa de mestrado. Agradeço pelas conversas, o carinho contínuo e a parceria.

Aos amigos Marcelo Paiva e Michelle Benedet, que foram imprescindíveis na minha aterrissagem à FAU e foram exímios orientadores durante o processo seletivo. A Maíra Fernandes, por ter me salvado inúmeras vezes e me apoiado incondicionalmente durante o processo, incluindo sua participação na Maré. A Romullo Fontenelle, por conversas esclarecedoras e salvadoras da dissertação, além do cuidado e atenção com as imagens do trabalho. A Camila Aquino por todo o trabalho com a cartografia da dissertação e a sua paciência com mapas cariocas desordenados. Ao querido Artur Kim Shum pelos almoços e conversas sobre cidade, design e arquitetura.

A Lia Assumpção por todo apoio, conversas, almoços, áudios, telefonemas desesperados, orientações de um minuto e levantamentos de auto estima. A Amanda Carvalho pela nossa parceria e ajuda mútua na pesquisa. A Antonia Muniz pelas trocas acadêmicas, ajuda mútua nas diferentes fases das nossas pesquisas e a nossa reaproximação pelo mestrado. A Pedro Caetano Eboli por nossas conversas, leituras e compartilhamento de bibliografias. Às parceiras e amigas do LaDA/ESDI/UERJ pelas conversas, participação na Maré e todas as trocas ricas entre o Rio e São Paulo: Cristina Ibarra, Mariana Costard, Liana Ventura, Bibiana Serpa e Flavia Secioso.

A toda equipe da 11aㅡ Bienal de Arquitetura, sempre muito atenciosa, a qual pude compartilhar toda a minha trajetória e contar com o apoio contínuo. Aos amigos do APE 
- Estudos em Mobilidade por todos os momentos em que estivemos juntos e aprendizados que tanto me auxiliaram a entrar na FAU-USP.

À minha querida Nathalia Amatto que mesmo diante de todos os obstáculos e desafios esteve sempre ao meu lado me dando forças. À amiga Renata Gaui, por estar sempre ao meu lado mesmo na distância, me dar apoio em vários momentos e me inspirar constantemente. À amiga Amanda Russo, por todas as conversas, abraços e momentos de apoio, seu ânimo e gentileza que sempre me estimularam nesta trajetória.

À minha parceira de todos os momentos Ana Carolina Resende, por todo o seu apoio desde o início do trabalho, por compartilhar comigo todas as dificuldades, ideias, dramas, inseguranças, além das conquistas e vitórias. Agradeço por cozinhar para mim nos momentos mais difíceis, na qualificação e na entrega da dissertação, além de nossas discussões contínuas tão enriquecedoras.

À família Abe, por todo o carinho ao longo dos anos. A Paula Kaori Abe por seu cuidado, amor e respeito. A Giulia Abe, por todas as companhias, conversas sobre design e psicologia, risadas e parceria nestes últimos dois anos.

À minha família, por acreditar em mim, sempre me dar força para conquistar os meus sonhos e ser tão compreensiva nos meus momentos de ausência e correria. Agradeço a minha mãe por ser minha eterna melhor amiga e me passar a sua garra e energia para realizar esta pesquisa de mestrado. Agradeço ao meu pai pelas conversas, ensinamentos, amizade e suporte que sempre iluminaram o meu caminho. A Jackie, por todo seu carinho e envolvimento no processo, pelas nossas conversas e cumplicidade. Ao meu irmão amado Guilherme, por me lembrar que às vezes precisamos parar de fazer dever e devemos nos divertir e descansar, além do seu carinho e amor. À minha avó Heloísa, por todo apoio e torcida, amizade e cuidado, por propiciar momentos únicos e me fortalecer nos momentos difíceis.

Finalmente, a Tiago Abe, a pessoa que me deu a mão, me permitiu sonhar grande junto com ele e desbravar o mundo. Agradeço por ser meu melhor parceiro, companheiro de todos os momentos, por tudo que passamos juntos neste período, da Tailândia à Costa Rica, de perto ou de longe, por ser a pessoa que mais acreditou em mim e atrás 
das cortinas se entregou de coração ao meu trabalho. Agradeço com todo meu amor por abraçar o design como se fosse a sua própria profissão e mesmo de fora, sobrecarregado de trabalho, por ter lido cada palavra, linha e texto, por todos os comentários, além de discussões e ideias. Agradeço por me fortalecer nos momentos de medo e insegurança e também pelos momentos de alegria e celebração, esta dissertação é só o começo da nossa parceria. 



\section{Resumo}

As iniciativas comunitárias em assentamentos urbanos informais e áreas periféricas metropolitanas vêm resistindo por décadas questões de vulnerabilidade social por meio da cultura, arte, educação e outras práticas que resultam em engajamento social e transformações espaciais. Neste sentido, a presente pesquisa escolheu como recorte a atuação de um coletivo de ativistas culturais - ativos nos eixos "Arte e Cultura", "Desenvolvimento Territorial" e "Comunicação" - da organização não governamental Redes da Maré. Trata-se de uma iniciativa comunitária que atua desde 2007 em diversos espaços de uso coletivo do Complexo da Maré, um agrupamento de dezessete favelas localizadas na Zona Norte da cidade do Rio de Janeiro. Este estudo de base experimental qualitativa tem como objetivo apresentar aspectos relevantes levantados em três etapas de colaboração realizadas no Complexo da Maré nos últimos dois anos de pesquisa. A partir da vivência e da troca de experiências e aprendizados da designer pesquisadora em parceria com coordenadores, funcionários e participantes da iniciativa, o trabalho apoiou-se em abordagens do design social participativo, codesign e design anthropology. Com foco nas formas de improvisação e os modos de cooperação presentes em ações que permeiam as atividades da iniciativa, esta pesquisa buscou gerar aprendizados e reflexões para designers e arquitetos brasileiros no intuito de suscitar caminhos para processos de co-criação no espaço urbano por meio de abordagens processuais, experimentais e colaborativas. Além disso, a investigação almeja dar relevância às práticas populares e periféricas nos espaços de uso coletivo da metrópole e, paralelamente, enriquecer o campo de atuação do design no âmbito informal e urbano.

Palavras-chave: Design e Cidade, Codesign e co-criação, Rio de Janeiro, Favela, Complexo da Maré 



\section{Abstract}

The community initiatives in informal urban settlements and metropolitan suburban areas have been resisting questions of social vulnerability by way of culture, art, education and other practices that result in social engagement and spatial transformation for decades. In that sense this study chose as its subject the action of a collective of cultural activists - active in the axis "Culture and Art", "Territorial Development" and "Communication" - of the non-governmental organization Redes da Maré. This community initiative acts since 2007 in diverse spaces of collective use in Complexo da Maré, a grouping of seventeen favelas located in the north side (Zona Norte) of the city of Rio de Janeiro. This practice-led research study has the objective of introducing relevant aspects that emerged from three phases of collaboration executed in Complexo da Maré in the past two years of research. From the day to day exchange of knowledge and living experiences of the design researcher partnering with coordinators, staff and participants of the initiative, the research was supported by social participatory design, codesign and design anthropology approaches. Focusing on forms of improvisation and modes of cooperation present in actions that permeate in the initiative's activities, this research study sought to generate learning and reflections for brazilian designers and architects with the purpose of opening pathways for co-creation processes in the urban space by way of procedural, experimental and collaborative approaches. Furthermore, the investigation aims to give relevance to popular and suburban practices in the metropolitan spaces of collective use, and in parallel enrich the field of action of informal and urban design.

Keywords: City and Design, Codesign and co-creation, Rio de Janeiro, Favela, Complexo da Maré 



\section{LISTA DE FIGURAS}

Figura 1: mapa de percurso de deslocamento de Botafogo até o Centro de Artes da Maré na cidade do Rio de Janeiro, Complexo da Maré, Rio de Janeiro.

Fonte: autora da dissertação, 2018. $-31$

Figura 2: comunidades do Complexo da Maré, Rio de Janeiro.

Fonte: Guia de Ruas da Maré, 2014. $-72$

Figura 3: mapa do Complexo da Maré, Rio de Janeiro.

Fonte: Camila Aquino e autora da dissertação, 2018. $-74$

Figura 4: Nova Holanda com vista para o Morro do Timbau.

Fonte: fotógrafo Douglas Lopes, 2017. 85

Figura 5: Nova Maré e a sua arquitetura. Fonte: fotógrafo Douglas Lopes, 2017. 86

Figura 6: exemplos de usos e apropriações na Nova Maré, tais como a caixa d'água que vira piscina e a garagem que vira restaurante. Fonte: autora da pesquisa, 2017.

Figura 7: Feira livre na Nova Holanda, Complexo da Maré.

Fonte: fotógrafo Douglas Lopes, 2017.

Figura 8: estrutura da Redes da Maré, seus eixos de atuação, projetos e responsáveis.

Fonte: elaborado pela autora, 2018 94

Figura 9: linha do tempo Redes da Maré com alguns de seus feitos desde 2012.

Fonte: elaborado pela autora em colaboração com Geisa Lino, 2017. 96

Figura 10: mapa da Maré, os espaços utilizados pela Redes da Maré e suas especificações. Fonte: elaborado pela autora, 2017. Foto 1 de Luiza Xavier; foto 2 de Elisângela Leite; fotos 3, 4 e 8 de Douglas Lopes; fotos 5, 6 e bibliotecas da autora; foto 7: DBUAA. 101

Figura 11: Vista da Avenida Brasil na Passarela 8. Fonte: autora da dissertação, 2017.___113

Figura 12: processo de construção do triciclo multimídia a partir de uma bicicleta de carga. Fonte: fotógrafo Douglas Lopes, 2016. 115

Figura 13: equipe reunida na $1^{\underline{a}}$ Rodada de Cicloativismo.

Fonte: fotógrafo Douglas Lopes, 2016. 118

Figura 14: trajeto de deslocamento da Lona Cultural até a Praça do Parque União com o triciclo multimídia. Fonte: elaborado pela autora da dissertação, 2018. 120

Figura 15: grupo preparado para o passeio ciclístico ao redor do triciclo multimídia. Fonte: fotógrafo Douglas Lopes, 2016. 121

Figura 16: A cicloativista Sarah Alves ensinando jovens a montar uma bicicleta do zero na frente do CAM. Fonte: fotógrafo Douglas Lopes, 2016. 
Figura 17: transformando pallets de madeira em um jardim vertical.

Fonte: fotógrafo Douglas Lopes, 2016. 124

Figura 18: estrutura de telão montada na área externa em frente ao CAM.

Fonte: fotógrafo Douglas Lopes, 2016. 128

Figura 19: Todos atentos a projeção de vídeo. Fonte: fotógrafo Douglas Lopes, 2016. 131

Figura 20: montagem coletiva do jardim vertical na área externa ao CAM.

Fonte: fotógrafo Douglas Lopes, 2016. $-132$

Figura 21: Produção das bombas de sementes. Fonte: fotógrafo Douglas Lopes, 2016._-_133

Figura 22 passeio ciclístico do CAM até o Parque Ecológico da Maré.

Fonte: fotógrafo Douglas Lopes, 2016. $-134$

Figura 23: arremeçamento de bombas de sementes no Parque Ecológico.

Fonte: fotógrafo Douglas Lopes, 2016. 134

Figura 24: trajeto que parte do CAM até a Lona Cultural.

Fonte: elaborado pela autora, 2018. $-141$

Figura 25: trajeto que parte da passarela nove (Rua Teixeira Ribeiro) até a Lona Cultural.

Fonte: elaborado pela autora, 2018. 143

Figura 26: outros caminhos que aprendi para me deslocar sozinha pela Maré.

Fonte: elaborado pela autora, 2018. $-145$

Figura 27: entrada da Lona Cultural Herbert Vianna na Rua C.

Fonte: autora da dissertação, 2017. 147

Figura 28: intervenções nos muros da Lona Cultural.

Fonte: fotógrafo Douglas Lopes, 2014. 148

Figura 29: interior dos muros da Lona Cultural Herbert Vianna.

Fonte: autora da dissertação, 2017. 148

Figura 30: interior da Biblioteca Municipal Jorge Amado.

Fonte: autora da dissertação, 2017._-_-_- 148

Figura 31: varal de trabalhos infantis. Fonte: fotógrafo Douglas Lopes, 2017. 151

Figura 32: aula sobre a Malala no dia internacional da mulher.

Fonte: fotógrafo Douglas Lopes, 2017. 151

Figura 33: processo de montagem do muro 'Meu sonho para a Maré é...'

Fonte: autora da dissertação, 2017. 153

Figura 34: resultado final do muro 'Meu sonho para a Maré é...'

Fonte: elaborado pela autora, 2017. 154

Figura 35: Centro de Artes da Maré. Fonte: fotógrafo Douglas Lopes, 2017. 156 
Figura 36: interior do Centro de Artes da Maré. Fonte: fotógrafo Douglas Lopes, 2017.__156 Figura 37: concerto de música do cantor africano Zola Star.

Fonte: fotógrafo Douglas Lopes, 2017. 159

Figura 38: algumas referências levantas na plataforma Pinterest.

Fonte: captura de tela da página web Pinterest, 2017. 165

Figura 39: bancos com solda de garrafa pet.

Fonte: imagem extraída da página web Pinterest, 2017. 166

Figura 40: caixas presas com prendedores de papel.

Fonte: imagem extraída da página web Pinterest, 2017. 166

Figura 41: papel com frase "Este lugar precisa de..." utilizado como suporte para geração individual de ideias. Fonte: autora da dissertação, 2017. 172

Figura 42: participantes exercitando a geração de ideias para o CAM.

Fonte: autora da dissertação, 2017. 172

Figura 43: participantes olhando as referências projetadas em uma parede do CAM.

Fonte: autora da dissertação, 2017. 174

Figura 44: desenhos de experimentação com materiais disponíveis no CAM.

Fonte: autora da dissertação, 2017. 175

Figura 45: experimentando as poltronas, sua altura e posicionamento para o melhor conforto. Fonte: autora da dissertação, 2017. 176

Figura 46: experimentação da espacialidade dos banheiros do CAM.

Fonte: autora da dissertação, 2017. 176

Figuras 47: Marcha Contra Violência na Maré. Fonte: fotógrafo Douglas Lopes, 2017._-_177

Figuras 48: praça infantil no local da fronteira entre a Nova Holanda e a Nova Maré. Fonte: fotógrafo Douglas Lopes, 2017 178

Figura 49: Mesquita e Lopes colocando os pallets no 'burro sem rabo'.

Fonte: autora da dissertação, 2017. 179

Figura 50: Mesquita carregando o 'burro sem rabo' com pallets em cima.

Fonte: autora da dissertação, 2017. 179

Figura 51: ferro-velho na Maré. Fonte: autora da dissertação, 2017. 180

Figura 52: materiais na calçada prontos para a produção e construção.

Fonte: autora da dissertação, 2017. 181

Figura 53: participantes da oficina ativos na construção do sofá itinerante.

Fonte: autora da dissertação, 2017. 181

Figura 54: Gomes e Lopes fixando o sofá itinerante. Fonte: autora da dissertação, 2017.__182 
Figura 55: participantes trabalhando juntos na pintura das peças produzidas.

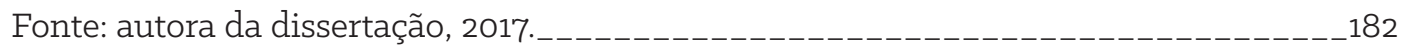

Figuras 56 e 57: momentos finais de construção coletiva e resultado dos objetos construídos. Fonte: autora da dissertação, 2017. 183

Figuras 58 e 59: momentos finais de construção coletiva e resultado dos objetos construídos. Fonte: autora da dissertação, 2017. 184

Figura 6o: triciclo multimídia sendo utilizado em uma exposição de fotografias, como aparato de exposição. Fonte: autora da dissertação, 2017.

Figura 61: sofás em uso para evento de celebração no CAM.

Fonte: fotógrafo Douglas Lopes, 2017. 212

\section{LISTA DE QUADROS}

Quadro 1: conceitos análogos e suas definições. Fonte: desenvolvido pela autora.

Fonte: autora da dissertação, 2017. 195

\section{LISTA DE SIGLAS}

BOPE - Batalhão de Operações Policiais Especiais da PMERJ

CAM - Centro de Artes da Maré

CEASM - Centro de Estudos e Ações Solidárias da Maré

CODE - Center for Codesign Research

DBUAA - Deutsche Bank Urban Age Award

DA - Design anthropology

ESDI/UERJ - Escola Superior de Desenho Industrial, Universidade do Estado do Rio de Janeiro

FAPESP - Fundação de Amparo à Pesquisa do Estado de São Paulo

FAU/USP - Faculdade de Arquitetura e Urbanismo da Universidade de São Paulo

FFLCH/USP - Faculdade de Filosofia, Letras e Ciências Humanas da USP

IBGE - Instituto Brasileiro de Geografia e Estatística

LaDA/ESDI/UERJ - Laboratório de Design e Antropologia da ESDI/UERJ

PMERJ - Polícia Militar do Estado do Rio de Janeiro

PUC-Rio - Pontifícia Universidade Católica do Rio de Janeiro

SEBRAE - Serviço Brasileiro de Apoio às Micro e Pequenas Empresas 


\section{Sumário}

Introdução

Contextualização do estudo 25

O percurso da pesquisa 35

O trabalho em processo: buscando as respostas no campo 37

Capítulo 1. O Design atento ao território e sua postura ativista

1.10 descolamento das práticas tradicionais de design: qual prática estamos buscando? 52

1.2 Uma postura ativista no design 62

Capítulo 2. Contextualização: o Complexo da Maré e suas lideranças comunitárias 71

2.1 Um breve histórico do Complexo da Maré 71

2.2 A Maré, seus espaços e seu cotidiano 84

2.3 A Redes de Desenvolvimento da Maré: a ação em rede no território 90

2.4 De Coletivo Maré para Redes da Maré: entre autonomia e organização 100

Capítulo 3. Processos de experiências e aprendizados na Maré 105

3.1 Escolha de abordagens 106

3.2 Visitas ocasionais: aprendendo com quem já faz 112 
3.2.1 Conhecendo os parceiros da Redes da Maré e suas formas de fazer 117

3.2.2 Treinando a observação participante 126

3.2.3 Táticas e técnicas do corpo na Maré 129

3.2.4 Reflexões e aprendizados 134

3.3 Imersão no Complexo da Maré: reconhecendo o território 135

3.3.1 Configuração de uma rotina de pesquisa no território 136

3.3.2 Adentrando espaços e a busca por autonomia 140

3.3.3 A Lona Cultural Herbert Vianna 146

3.3.4 Vivências na programação da Lona Cultural 149

3.3.5 Centro de Artes da Maré 155

3.3.6 Vivências na programação do Centro de Artes da Maré 158

3.3.7 Reflexões e aprendizados 160

3.4 Da observação para a ação: a proposição em demandas locais 162

3.4.1 Programação para oficina de construção-teste

no Centro de Artes da Maré 164

3.4.2 Entre improvisação e apropriação:

a oficina de marcenaria e construção teste 169

3.4.3 Reflexões e aprendizados 182

\section{Capítulo 4. As diferentes formas de colaboração} e o desafio da co-criação 187

4.1 Aspectos relevantes sobre colaboração levantados na investigação 187

4.1.1 A colaboração por meio de práticas espontâneas de design 188

4.1.2 A colaboração por meio da cooperação, do aprendizado e das táticas 191

4.1.3 A colaboração por meio do desenho coletivo e da improvisação 196

4.1.4 A colaboração por meio da correspondência 199

4.1.5 A colaboração por meio da intuição e da articulação 204

4.1.6 A colaboração por meio da performatividade 209

4.2 Desdobramentos após o término do processo narrado 211

4.3 Observações sobre a colaboração em diálogos externos 214

Considerações finais 219 




\section{Introdução}

\section{Contextualização do estudo}

O antropólogo britânico Tim Ingold frequentemente inicia suas obras convidando seu leitor a pegar em sua mão e segui-lo através de suas narrativas que constroem caminhos teóricos e empíricos, quase como se estivesse contando uma história. No mesmo rumo, apresento esta pesquisa de mestrado como uma longa narrativa, na qual convido leitores a percorrerem comigo o processo que vivenciei nos últimos dois anos de trabalho em parceria com ativistas culturais do Complexo da Maré, um conjunto de dezessete favelas na Zona Norte da cidade do Rio de Janeiro.

A pesquisa partiu de indagações pessoais com relação à participação de designers brasileiros na transformação e requalificação de espaços urbanos. Como uma profissional graduada em design de produtos, proveniente da PUC-Rio, escola em que me graduei e que possui um largo histórico associado à participação em design em sua grade curricular ${ }^{1}$, sempre estive atenta às questões urbanas e sociais e o modo como o design lidava com elas.

No ano de 2013, ano final de graduação, tive a oportunidade de trabalhar como assistente de pesquisa no prêmio alemão Deutsche Bank Urban Age Award Rio 2013 (DBUAA), o qual, ao lado do então curador Dr. Marcos L. Rosa, atuei em um mapeamento que analisava práticas espaciais realizadas por iniciativas articuladas em rede 
no espaço urbano². Este mapeamento teve como resultado um levantamento de mais de 150 iniciativas que atuavam na melhoria de espaços de uso coletivo na Região Metropolitana do Rio de Janeiro3.

Estas eram majoritariamente compostas por atores da sociedade civil que, por meio de atitudes de resiliência urbana, propiciavam novas configurações espaciais e sociais para moradores e frequentadores, tais como hortas urbanas, atividades educacionais, grupos de dança, música, teatro e arte, entre muitos outros. Tal fenômeno, estudado por Rosa (2015, p. 160, tradução nossa) em sua tese de doutorado, aponta que as "iniciativas comunitárias indicam a habilidade de cidadãos apresentarem soluções para desafios colocados pela vida cotidiana, e o uso da criatividade para transformar e multiplicar os recursos existentes"4.

Opostas à lógica monofuncional da cidade e, sistemas urbanos modernos, as iniciativas realizam um trabalho de base, "de baixo para cima", considerando as relações locais, as técnicas, a vocação das comunidades e outros aspectos que promovem um efetivo engajamento e transformação social em longo prazo. O termo "de baixo para cima”, ou como referenciado na língua inglesa 'bottom up', é utilizado por Rosa (2011, p. 14), para designar ações realizadas pela sociedade civil na escala local, ou seja, uma atitude distinta ao modo de planejamento 'top-down', "de cima para baixo", observado majoritariamente e caracterizado pela implementação do desenho local para o espaço urbano com base em decisões políticas centralizadas e distantes da realidade local.

Entre as 150 iniciativas mapeadas, duas foram contempladas pelo prêmio: a comunidade Vila Autódromo, da Zona Oeste, e o Coletivo Maré, da Zona Norte da cidade. Ainda durante a organização do prêmio, que contava com uma fase de quatro meses

\footnotetext{
2. Em sua tese de doutorado, o arquiteto Dr. Marcos Rosa desenvolve uma plataforma de pesquisa, na qual desenha um método para compreender a imensa quantidade de iniciativas existentes na região metropolitana de São Paulo, a sua capacidade de uso e transformação espacial através de camadas - entre as estruturas permanentes às pessoas e coisas -, e a sua articulação em rede em meio às largas infraestruturas urbanas. Para mais informações veja Rosa, 2015.

3. Cf. Rosa, M. L.; Montuori, B. F. DBUAA Rio 2013: Field Work Report. Berlin, 2013.

4. No original: "community-based initiatives indicate the ability of citizens to present solutions to challenges posed by everyday life, and use creativity to transform and multiply existing resources".
} 
de pesquisa em campo, incluindo visitas a iniciativas por toda a cidade ${ }^{5}$, me aproximei da segunda iniciativa com o intuito de conhecer o seu trabalho e encorajá-los a se inscrever. Independente e com seus membros provenientes da própria Maré ${ }^{\text {, o }}$ grupo havia iniciado atividades pontuais em espaços livres do território, incluindo o Pontilhão Cultural, projeto que conquistou os jurados do DBUAA e os conferiu o segundo lugar no prêmio. Pontilhão Cultural é um espaço livre ocupado embaixo do viaduto em que passa a Avenida Governador Carlos Lacerda, popularmente conhecida como Linha Amarela. Anteriormente dominado por uma facção criminosa e afetado pelo contínuo despejo de lixo, foi transformado e utilizado para fins culturais e pedagógicos por membros do Coletivo Maré, em parceria com o coletivo Skate Maré, moradores e frequentadores locais.

Na época, o grupo era coordenado por dois moradores: Geisa Lino e Alberto Aleixo. Ambos nasceram e cresceram no Complexo da Maré e viveram boa parte de suas infâncias e adolescências convivendo, participando e atuando em atividades realizadas pela Redes de Desenvolvimento da Maré, popularmente conhecida como Redes da Maré7, organização da sociedade civil presente desde 2007 no território. Embora houvesse uma grande aproximação do Coletivo Maré com a Redes da Maré, em um primeiro momento reconheci o primeiro como independente do segundo, no entanto, conforme a pesquisa se desenvolveu compreendi que ambos eram co-dependentes, visto que algum tempo depois que o Pontilhão Cultural foi nomeado como vencedor, os membros do Coletivo Maré foram convidados a trabalhar na Redes como um de seus tecedores. ${ }^{8}$. Uma vez que Lino, Aleixo e outros membros do Coletivo Maré se colocaram como atores da Redes da Maré, cunhei a pesquisa com o nome da iniciativa

\footnotetext{
5. O propósito da pesquisa de campo no DBUAA foi identificar, conhecer, mapear, aproximar-se e encorajar tais iniciativas enquanto não-arquitetos ativos na transformação e qualificação urbana a participar do prêmio que contemplava cem mil dólares para os vencedores.

6. Opto por utilizar o termo Maré ao me referir ao Complexo da Maré, visto que é a forma falada no cotidiano local.

7. Adoto o nome Redes da Maré na dissertação, por se tratar da forma comum como seus colaboradores se referem à organização.

8. O termo "tecedor" é utilizado entre funcionários, voluntários e participantes da organização Redes da Maré. Cunhado por Eliana Sousa Silva, diretora da Redes, a ideia de tecer o território é pautada na extensiva articulação que a ONG tem por todo o território e sua capilaridade entre os diversos públicos que atende.
} 
ao invés do coletivo a partir de uma decisão conjunta entre Lino e eu. De todo modo, a relação entre o Coletivo Maré e a Redes da Maré será abordada no segundo capítulo desta dissertação, o qual traço uma breve contextualização do Complexo da Maré e apresento a estrutura da Redes da Maré.

Após a experiência profissional no DBUAA, somada ao período entre 2014 e 2015 em que estive em São Paulo, imersa no mercado de trabalho na área de design, notei o distanciamento existente entre profissionais da área com relação a questões complexas diárias ${ }^{9}$ presentes em metrópoles como Rio de Janeiro e São Paulo. Assim, diversos questionamentos com relação à atuação de profissionais, acadêmicos e estudantes de design com a cidade real foram surgindo: há designers atuando diretamente na cidade com as pessoas? Por que os espaços em que designers atuam são, em sua maioria, privados, privilegiados e sem envolvimento com questões de urgência na metrópole? Por que designers são majoritariamente associados ao mercado de luxo e a produção de bens autorais? Por que designers não estão envolvidos em decisões urbanas junto com outros atores como urbanistas, engenheiros, economistas e administradores e são associados a meros prestadores de serviço?

Outro ponto questionado foi o distanciamento entre o design e a arquitetura no âmbito profissional e acadêmico, visto que os tópicos 'cidade' e 'espaço urbano' ainda são diretamente associados à arquitetura e o urbanismo no que toca a ação projetual. Ao ingressar na pós-graduação da Faculdade de Arquitetura e Urbanismo da USP, observei a separação existente entre essas áreas, ainda que os tópicos de pesquisa e debate fossem extremamente relacionados ${ }^{10}$. Todavia, ao analisar trabalhos como

9. Me refiro a questões complexas diárias como a desigualdade social urbana, a precariedade de serviços públicos, a falta de direitos fundamentais e qualidade de vida, a falta de segurança pública, entre outros.

10. A FAU-USP baseava seu ensino numa ideia de projeto total a partir de seu currículo de 1962, que habilitava o arquiteto a projetar de objetos ao espaço urbano. No entanto esta base pedagógica foi limitada com a implementação do currículo mínimo de design, baseado no currículo pleno da ESDI/ UERJ e implementado em 1969 pelo Conselho Federal de Educação, que exigia que o curso de desenho industrial tivesse outras frentes de ensino que inflariam demasiadamente o currículo da arquitetura. Esta fase demarca o início da separação histórica entre os campos de design e arquitetura no Brasil, separação que culminaria em meados dos anos 1970 com a criação da APDINS-RJ (Associação Profissional dos Desenhistas Industriais do Rio de Janeiro), especialmente porque buscava-se valorizar e legitimar o campo do design, com a intenção de regulamentá-lo. Embora a intenção de separação 
'Handmade Urbanism' e ‘Urbanxchanger' de Rosa e Weiland (2013; 2017), os projetos do coletivo britânico Assemble (2017), a parceria acadêmica entre docentes da FAUUSP e comunidades de catadores de São Paulo (Santos; Salkurai, 2017), os projetos de codesign desenvolvidos pelo Laboratório de Design e Antropologia da ESDI/UERJ (Anastassakis; Szaniecki, 2016) e a base curricular da PUC-Rio em suas primeiras disciplinas de projeto na graduação (Couto in Oliveira et al., 2017), optei por evitar a separação entre áreas, visto que em ambas há pessoas com um mesmo objetivo comum: trabalhar com pessoas ao invés de para pessoas. Com este intuito, adotei a concepção de design sugerida pelo designer Victor Margolin (2007), também utilizada internacionalmente, a qual designers são uma classe composta por profissionais com habilidades para o desenvolvimento de projetos, sejam estes designers, arquitetos, urbanistas ou engenheiros.

Neste sentido, ao observar a potencialidade de ação coletiva (Thorpe, 2011), isto é, a capacidade de cooperação para promover transformação espacial e qualidade de vida (Rosa, 2015), exercida por membros da Redes da Maré, indaguei-me sobre como designers poderiam aprender e colaborar com grupos que já atuavam no espaço urbano. Este processo revelou que designers não precisavam criar projetos do zero ou reconfigurar espaços de acordo com referências estrangeiras, mas sim conhecer quem já costurava o tecido urbano e a partir deste ponto colaborar de acordo com as demandas já compreendidas por quem usa, atua e transforma os espaços.

Poucos meses antes de iniciar a pesquisa de mestrado, fui até a Maré encontrar-me com Lino e lá conheci Douglas Lopes, autor do acervo fotográfico apresentado neste trabalho. Neste momento eu ainda era pouco familiarizada com o território e por isso Lino me explicou o caminho da minha casa, localizada no bairro de Botafogo,

tivesse como objetivo a não precarização do seu ensino, Braga (2011) afirma que que a classe de designers cariocas responsável pela APDINS-RJ advogava por uma cisão entre as duas áreas em virtude do modo como desenho industrial era ensinado nas faculdades de arquitetura e a partir do currículo mínimo instaurado na ESDI/UERJ, definido como nacional. "A APDINS-RJ denunciava que ‘a questão não é ensinar desenho industrial e comunicação visual para arquitetos, mas sim capacitá-los legalmente para a prática, de forma precária, da atividade.' Segundo Valéria London, a proposta que a APDINS-RJ passou a defender era a de que as disciplinas de Desenho Industrial, para os cursos de Arquitetura, não tivessem o caráter formativo, e sim informativo" (Ibid., p. 163). Cf. Braga, 2011. 
até o Centro de Artes da Maré1, localizado na Rua Bittencourt Sampaio, número 181, Complexo da Maré. Embora já tivesse visitado a Maré diversas vezes, esta era a primeira vez que eu ia sozinha ao local utilizando transporte público.

O percurso (figura 1) - que será descrito algumas vezes ao longo do texto - iniciou-se no metrô de Botafogo, onde peguei o trem até a estação Cidade Nova e em seguida peguei um ônibus chamado 'parador', que seguia pela Avenida Brasil e, ao invés de seguir direto pela pista central, parava em todos os pontos da via.

Desde criança, a Avenida Brasil era reportada pelo meu círculo social como um lugar de perigo: assaltos, violência, dependentes químicos, grupos criminosos, tráfico de drogas, armas e outros aspectos que estereotipavam a região. Embora eu tivesse em mente que milhares de pessoas percorriam este trajeto cotidianamente, segui o caminho com medo e insegurança, enraizados devido anos de relatos negativos sobre o lugar. Ao chegar ao Centro de Artes da Maré (CAM), localizado entre as passarelas nove e dez da Av. Brasil, me comuniquei com Lino e como recomendado peguei uma moto-taxi até as proximidades da Lona Cultural Herbert Vianna, onde Lino se encontrava. Naquele momento, a fronteira de disputa entre facções criminosas ${ }^{12}$ era frequente no cruzamento entre as ruas Principal e Ivanildo Alves, localização exata da Lona Cultural. Ainda sem compreender esta dinâmica, fui com o moto-taxista até um ponto próximo, que se recusava a avançar, o que me deixou um pouco apreensiva.

Ao chegar à Lona Cultural encontrei Lino, que organizava os materiais infantis do projeto 'Nenhum a Menos ${ }^{13}$ e se preparava para uma reunião de equipe com outros funcionários da Redes da Maré. Coordenadora do espaço desde 2015, Lino é responsável pela sua organização, pelos cuidados com a infraestrutura e produção cultural e pela gestão de funcionários, voluntários e participantes. Ao vê-la atarefada, conversa-

11. Também referenciado como CAM, sigla para Centro de Artes da Maré.

12. O termo 'facção criminosa' refere-se a grupos armados envolvidos com tráfico de drogas e armas. Me aproprio aqui deste termo, pois é o mesmo utilizado por moradores da Maré.

13. O projeto Nenhum a Menos é direcionado para crianças de seis à oito anos e nove a doze anos com o intuito de promover a reinserção escolar e complementação pedagógica para crianças da Maré, com especial foco à crianças da comunidade Nova Maré, reconhecida como de baixo Índice de Desenvolvimento Humano, de acordo com Alberto Aleixo, atual Diretor da Redes da Maré. 0 projeto será detalhado no terceiro capítulo da dissertação. 

mos brevemente sobre a minha pesquisa e perguntei se poderíamos fazer uma parceria, na qual eu acompanharia seu trabalho e algumas atividades da Redes da Maré durante um período determinado e me colocaria à disposição para desenvolvermos algo que fosse relevante para a organização. Lino concordou com a troca proposta e se colocou aberta para a minha participação e vivência no território, sempre disponível para diálogos, trocas e aprendizados, permitindo inclusive a ampla divulgação de seu trabalho, trajetória e atuação na Redes da Maré na dissertação.

É importante ressaltar que apesar de contar com o apoio, empenho e esforço de diversas pessoas neste caminho, a intenção de realizar a pesquisa no âmbito da Redes da Maré foi inteiramente minha. Friso este fato, pois entrei neste contexto com uma postura de auto-convite, em que o único e possível caminho para a minha inserção era por meio de um viés informal, sem laços institucionais, recursos formais, suporte e nem contratos firmados. Por conta disso, acredito que embora o processo tenha sido menos estruturado, ele foi livre e sem amarras formais, me dando autonomia para escolher caminhos e tomar decisões.

Neste sentido, por meio da minha familiaridade com a base pedagógica de design da PUC-Rio, cunhada de 'Design e Parceria', como descrita pela professora Dra. Rita Couto $(1991)^{14}$, optei por firmar uma parceria com Lino e, consequentemente, com Lopes, a fim de direcionar o caminho de pesquisa. Ainda em processo de estruturação entre diferentes abordagens, tais como Design para Inovação Social (Manzini, 2008; Manzini, 2015) e o Design Social Participativo da PUC-Rio (Couto, 1991), a pesquisa, de base qualitativa e experimental, tomava sua forma conforme eu me aproximava do objeto de estudo.

14. Além de Couto (1991) pode-se compreender a concepção de Design e Parceria também por meio do artigo de Renata Araujo (in Oliveira et al., 2017, p. 19-28). Segundo Araujo (Ibid., p. 23)“Com a reforma curricular e a implantação de um novo currículo no ano de 2007, a metodologia de Design em Parceria foi consolidada como base para a disciplina DSG 1001 Projeto Básico Contexto e Conceito, de forma que todos os alunos no primeiro período vivenciam essa prática projetual. Uma abordagem social, que procura fugir do cunho assistencialista, com ações conjuntas entre as pessoas, e não de uma pessoa para a outra. Uma busca pelo trabalho cooperativo sem hierarquias. Um fazer "com" e não "para". O convite do Design em Parceria é para que esse processo com foco no ser humano seja compartilhado e parta da realidade vivida por um ou mais indivíduos. Que seja vivida também pelo designer, junto com o indivíduo ou um grupo, que deem sentido ao projetar. A solução de design é resultado e consequência desse processo". 
A partir deste ponto, no início do ano de 2016, iniciei meu diálogo com Geisa Lino, Douglas Lopes, Alberto Aleixo e outros tecedores com o objetivo de pesquisa de compreender como designers e pesquisadores poderiam colaborar com iniciativas comunitárias como a Redes da Maré. A cada visita que eu fazia, ainda que de maneira esporádica, notava como o grupo era totalmente autossuficiente e lidava com questões complexas do território que iam além das minhas habilidades como designer. Em razão disso, notei a necessidade de me aproximar com uma abordagem mais focada na observação, atenção e compreensão, de modo que eu pudesse aprender com aquelas pessoas e compreender aquele território antes de colaborar com ele.

Com auxílio da Professora Dra. Zoy Anastassakis ${ }^{15}$ tive acesso às abordagens de design anthropology (DA), em português 'design e antropologia', e codesign, termo reduzido para design colaborativo de acordo com o Center for Codesign Research (2018), que ampliaram meu campo de visão com relação às vivências na Maré e deram suporte para a realização da pesquisa. Em paralelo, me apoiei também no design social participativo, abordagem na qual fui formada na graduação e que tem a participação como premissa na prática projetual. Ao longo da dissertação relatarei em profundidade as abordagens que utilizei e sua relação direta com cada um dos processos vivenciados.

Por esta trajetória, o trabalho consolidou seu objetivo geral em como revelar aspectos relevantes acerca de experiências e aprendizados vivenciados em processos de colaboração, com base na parceria feita com ativistas da organização Redes da Maré, sobretudo quanto às formas de usar, improvisar, cooperar e transformar os espaços de uso coletivo no Complexo da Maré. Trato aspectos relevantes aqui como: posturas que possam facilitar o engajamento e a participação, modos de compreender as relações de poder e hierarquia nos processos colaborativos, particularidades que contribuam no entendimento do contexto, sentimentos úteis durante experiências de colaboração em campo, entre outros tópicos que foram levantados a partir de experiências e

15. Zoy Anastassalkis é designer pela ESDI/UERJ, mestre e doutora em antropologia pelo Museu Nacional, é professora titular e diretora da ESDI/UERJ e coordenadora do LaDA/ESDI/UERJ. Nosso primeiro contato foi em sala de aula na PUC-Rio quando assisti sua disciplina História do design brasileiro. Durante a pesquisa de mestrado, Anastassakis acompanhou e co-orientou não oficialmente o trabalho ao lado do Dr. Marcos Rosa e a orientadora Dra. Maria Cecilia Loschiavo dos Santos. 
aprendizados e serão abordados nos dois capítulos finais. Quanto ao termo 'ativista"16, o utilizo a fim de reforçar o caráter de resistência cotidiana existente no trabalho de cada um dos membros da organização, marcado por constantes conflitos, disputas e desafios, mas também por generosidade, cuidado e esperança.

Acredito ser relevante mencionar que este trabalho é um processo contínuo que não chegou a um fim - no meu ponto de vista, quase que uma antítese da noção de projeto - visto que o meu intuito foi e ainda é deixar processos vivos nas mãos de quem fica no lugar de trabalho, como evidenciado por Gatt e Ingold (in Gunn et al., 2013). O substantivo processo carrega diversas definições relevantes para este contexto: "ação ou operação contínua e prolongada de alguma atividade; curso, decurso, seguimento", ou "sequência contínua de fatos ou fenômenos que apresentam certa unidade ou se reproduzem com certa regularidade; andamento, desenvolvimento", ou ainda "método empregado para se fazer alguma coisa; maneira, procedimento" (Michaelis, 2018). No entanto, a definição de processo aqui adotada se delineia a partir da concepção elaborada por Ingold (2016) de que a vida, suas relações e encontros fazem parte de uma grande malha, e cada pessoa, coisa ou lugar são linhas que se encontram e formam nós. Estes nós evidenciam momentos de troca e aprendizado, porém não fazem com que as linhas se acabem ou terminem, ao contrário, elas continuam vivas, promovendo outros momentos, outras trocas e outras vivências ${ }^{17}$.

Desta maneira, processo representa uma série de encontros e vivências que geram aprendizados e experiências para novos encontros e vivências, que não param ou terminam, mas vão ao longo da vida (Id., 2012), ainda que hajam hiatos de tempo ou intervalos.

O processo é transversal à absolutamente tudo que ocorre enquanto são feitos e desfeitos os nós da malha da vida social, e está presente em nossa capacidade de se deixar levar pelos movimentos e crescimentos vitais inerentes ao ser humano (Ingold, 2016, p. 10-15).

Considerando cada momento vivido uma parte do processo, que foi se enriquecendo ao longo do tempo como narro no terceiro capítulo, hoje o reconheço como um meio para entender a prática de design no âmbito coletivo e urbano, de modo que as

16. Em Rosa (2015) os ativistas são reconhecidos como agentes locais, ou agentes articuladores do contexto que realizam ações e promovem redes no território.

17. Ibid., p.10. 
respostas vão surgindo nos próprios nós e em seus interstícios. Assim, por meio deste trabalho me objetivo levantar reflexões e suscitar caminhos para designers brasileiros que trabalham ou anseiam trabalhar com projetos de design no espaço urbano por meio de abordagens e técnicas experimentais que envolvam habilidades de atenção, aprendizado, troca e colaboração.

No que toca a colaboração trata-se de um substantivo que se refere ao "ato ou efeito de colaborar, de trabalhar em conjunto; cooperação, ajuda" segundo o dicionário Michaelis (2018). Aqui, é utilizado especialmente em sua variação como adjetivo, dado no termo 'colaborativo'. Para este trabalho, esse termo é pensado à luz da ideia de "desenhar coisas juntos" - do inglês 'drawing things together'-, descrito pelo historiador da ciência Bruno Latour (2009), que será discutida ao longo da dissertação. Tratase de pensar a prática envolvendo a presença de pessoas que darão continuidade ao processo mesmo quando o profissional ou pesquisador não está presente (Gatt; Ingold in Gunn et al., 2013).

Com base nestas observações cautelosas, esta investigação dá relevância às práticas populares nos espaços de uso coletivo da metrópole, lançando luz às suas forças transformadoras, às suas articulações entre atores que dão vida a encontros e trocas e o seu domínio e conhecimento sobre o território que vão muito além das forças totalizantes e hegemônicas. Em paralelo, a investigação buscou valorizar uma atuação do design no âmbito informal e urbano, que ultrapassa as amarras industriais e tecnocráticas, o compromisso com o capital e o sistema de nomenclaturas que define quem está ou não apto a construir a cidade. A seguir, descrevo brevemente como foi realizado o percurso do trabalho e, na sequência, apresento como esta dissertação foi organizada e onde cada conteúdo está localizado.

\section{O percurso da pesquisa}

Como citado, após a minha primeira ida a Maré, poucos meses antes de iniciar a pesquisa de mestrado, estabeleci um primeiro contato com Lino de forma que a nossa comunicação fosse iniciada. Ao longo do primeiro ano de trabalho, realizei disciplinas na FAU-USP junto às imersões teóricas e sistematizei conteúdos necessários para to- 
das as imersões em campo, especialmente com relação à compreensão do contexto da Maré e sua formação social, cultural e geográfica, bem como em abordagens experimentais no design que fossem úteis na investigação.

Neste sentido, levantei teorias e abordagens que pudessem evidenciar caminhos práticos, mas também aprendizados vivenciados por outros pesquisadores que pudessem iluminar o meu processo. Assim, compilei estes materiais e fui a campo pela primeira vez em junho de 2016, quando iniciei minhas participações em eventos temporários coordenados por Geisa Lino, envolvendo o Centro de Artes da Maré e a Lona Cultural Herbert Vianna. Ao longo do segundo semestre de 2016 frequentei essas atividades pontuais e pude compreender como ocorria a dinâmica espacial naquele contexto. Pude entender quais eram os espaços mais usados e quais eram as relações entre os atores centrais e seus parceiros, a fim de visualizar a rede articuladora existente, a qualidade das atividades, as ferramentas empregadas, entre outros aspectos úteis para visualizar o que já se fazia no local.

Nesta primeira fase, apenas acompanhei as atividades utilizando meios como a observação participante e anotações. Após essas experiências, notei que era preciso mais tempo em campo para compreender o contexto, o que me fez retornar para a Maré com o intuito de realizar uma segunda fase de investigação, isto é, acompanhar por um mês as atividades diárias e conhecer melhor o território. Este período ocorreu em março de 2017 e saiu completamente dos meus planos e expectativas, o que me obrigou repensar inteiramente a pesquisa, porém me levaram a uma oportunidade de colaboração, a qual me coloquei a frente para organizar junto a Lino e Lopes.

Esta proposta de atividade colaborativa na Maré me levou a terceira e última fase de campo, a qual foi realizada com o apoio do designer do grupo O Formigueiro, Vinícius Mesquita. Realizamos uma oficina de marcenaria de quatro dias no Centro de Artes da Maré no mês de maio de 2017, que gerou diversas questões e aprendizados sobre o desafio da co-criação e as diferentes formas de colaboração, discutidos no capítulo quatro.

Após esta experiência, me debrucei sobre a imensidade de reflexões levantadas neste processo e, apenas em outubro de 2017, retornei a Maré para observar os desdobramentos da atividade realizada e escutar depoimentos e impressões dos parceiros sobre 
o processo. Entrelaçado a todas essas vivências, realizei diversas imersões teóricas, especialmente com apoio do meu grupo de estudos 'Por um design relacional', formado em 2016 com as pesquisadoras Ana Julia Melo Almeida, doutoranda da FAU-USP, e Viviane Mattos Nicoletti, mestranda da FAU-USP, ambas também orientadas pela Professora Dra. Maria Cecilia Loschiavo dos Santos.

Concluo os dois anos de mestrado com esta dissertação, que apresenta as peculiaridades de cada uma das etapas vividas em campo e seu entrelaçamento com bibliografias e outras experiências, necessárias para compreender as formas de colaboração possíveis em um trabalho de cunho participativo. No tópico a seguir, apresento a organização da dissertação, a divisão de capítulos e a literatura de base utilizada em cada um deles, levando em consideração a caracterização desta pesquisa, isto é, qualitativa, experimental e exploratória, que não visa avaliar resultados, mas sim refletir sobre processos.

\section{O trabalho em processo: buscando as respostas no campo}

Uma vez que o processo vivenciado ocorreu de forma não linear, já que todas as experiências foram imprevisíveis, é inviável relatá-lo de maneira rigorosa, pontual e em uma estrutura metódica. No entanto, procuro narrá-lo cronologicamente e com atenção a cada momento em que recortes e delimitações foram organicamente estabelecidos na forma em me deixei levar pelas vivências naquele local com aquelas pessoas, como sugerido por Ingold (2016). O território e seu caráter vivo, emergencial e latente impossibilitou raciocínios pré-concebidos, porém elucidou a necessidade de uma postura flexível, na qual eu estivesse preparada para as imprevisibilidades que vinham ao meu encontro.

Assim, busco apresentar nesta dissertação a minha perspectiva com relação à atuação da Redes da Maré partindo de três caminhos sugeridos pelo antropólogo Bronislaw Malinowski1 ${ }^{18}$ (in Castro, 2014, p. 113-114), que são:

18. Bronislaw Malinowski (1884-1942) foi um antropólogo polonês que estudou na Inglaterra, referência na área da antropologia por suas pesquisas de campo e o trabalho etnográfico. De acordo com o autor Celso Castro (2016, p. 93), embora não tenha sido o primeiro a realizar esta forma de fazer pesquisa, "entrou para a tradição antropológica como uma espécie de 'inventor' desse método de pesquisa, em particular na sua dimensão de 'observação participante' da vida dos nativos". 
1. A organização da iniciativa e a autonomia de sua cultura, isto é, um esboço da estrutura organizacional, atores, espaços usados, projetos, parceiros e outros itens relevantes na compreensão local;

2. Uma compilação de relatos vividos baseados em interações, trocas e aprendizados com pessoas do local de acordo com o cotidiano da iniciativa, as atividades realizadas, os participantes e beneficiados e a relação de pertencimento com a Maré;

3. Uma compilação de depoimentos, narrativas características e pronunciamentos típicos, isto é, a linguagem, costumes e rituais.

O primeiro caminho é apresentado no capítulo dois, sobre o contexto da Maré e da Redes da Maré, enquanto o segundo e o terceiro são apresentados ao longo dos capítulos três, sobre o processo, e quatro, sobre a relação das vivências com a literatura da pesquisa. Detalho como estes caminhos são apresentados nos capítulos após apresentar os questionamentos que nortearam a pesquisa. Objetivamente, busco por estes caminhos apresentar o ponto de vista dos atores, sua relação com a vida no local e sua visão de mundo ${ }^{19}$. Embora esta seja uma pesquisa em design e arquitetura, busquei na antropologia meios que ampliassem o caráter exploratório do trabalho, tais como: a observação participante, registros frequentes em um diário de campo e coleta de dados. Estes recursos foram imprescindíveis tanto na macro-visualização da iniciativa quanto na micro, isto é, de uma visão holística para percepções minuciosas que contribuíram imensamente no processo.

É importante mencionar que Malinowski possuía uma relação com os sujeitos investigados completamente diferente da minha. A ideia de sociedade em tribos compostas por nativos não se aplica a esta pesquisa e o distanciamento entre pesquisador e sujeito são amplamente reduzidos. No meu caso, o grupo estudado encontra-se em um contexto similar ao meu: falamos a mesma língua, compartilhamos muitas referências culturais, vivemos em uma metrópole, levamos uma vida conectada e em rede, visto que, assim como eu, a grande maioria das pessoas com quem estive possui telefone celular ou computador com acesso à internet, tem acesso a conteúdos culturais, serviços públicos e privados - independente de sua qualidade -, bem como tem obrigações 
como qualquer outro cidadão na cidade. Evidentemente, há um ponto macro de distanciamento, e este está na diferença social econômica que nos separa. Eu não nasci, cresci ou frequentei a favela até trabalhar no prêmio DBUAA, me aproximar de Lino e realizar esta pesquisa. Venho de um espaço de privilégios separador que sempre generalizou a imagem da favela como lugar de violência e outros estereótipos que caíram por terra conforme realizei a pesquisa.

Seguindo a linha de Malinowski ${ }^{20}$, apoio-me na ideia de que "o autor é ao mesmo tempo seu próprio cronista e o historiador, enquanto suas fontes sem dúvida são facilmente acessíveis, mas também supremamente esquivas e complexas; elas não estão corporificadas em documentos materiais, fixos, mas no comportamento e na memória de homens vivos". Diferente do antropólogo, que dedicou anos de trabalho observando diferentes povos, tribos e suas culturas, esta pesquisa foi desenvolvida em um período de tempo limitado, o que me obrigou selecionar partes específicas para investigação, tais como nicho de atores, espaços e atividades específicas.

Todavia, vale mencionar que a minha aproximação à antropologia ocorreu a fim de buscar meios que me auxiliassem a levantar reflexões sobre os aprendizados no que se refere ao fazer colaborativo com ativistas da Maré. Em razão disso, valho me da linha de pensamento de Ingold (2013), que repensa a prática antropológica como espaço para observação participante, abrindo mão de uma prática descritiva incessante, em que o profissional não se deixa levar pelas vivências com o outro. Esta observação participante é baseada nas ideias propostas no livro 'Making'21, as quais o autor advoga que a prática é a própria antropologia em si, ou seja, um estudo com as pessoas e não sobre as pessoas. Esta postura requer que a prática seja transformadora e permita que o conhecimento venha de dentro, por meio da correspondência entre o pesquisador e os sujeitos estudados.

Ao traduzir este raciocínio para o design, foi possível pensar em uma prática projetual que abre espaço para vivências e aprendizados contínuos, que se mantém vivos nas mãos dos meus parceiros, livre de obrigações com resultados e produtos finais.

\footnotetext{
20. Ibid., p. 96.

21. Ingold, op. cit., p. 1-15.
} 
Seguindo este ponto de vista, preocupei-me em vivenciar experiências no local apenas realizando relatos ao final de cada encontro. Isto possibilitou um entendimento mais detalhado do contexto, visto que as peças sobre como funciona a organização iam se encaixando como um quebra-cabeça. Com a liberdade de 'afetar-me em campo', pude trabalhar questões mais profundas como o sentimento de diferença social e econômica e as relações hierárquicas a fim de encontrar uma relação de alteridade entre mim e eles.

Iniciei a pesquisa com dois espaços em mente para a investigação: a Lona Cultural Herbert Vianna e o Pontilhão Cultural. No entanto, ao realizar as primeiras visitas a Maré, observei que o uso de espaços era bem mais complexo e que havia uma separação de uso entre espaços permanentes e efêmeros, a qual entro em detalhes no segundo capítulo. Assim, abri mão de focar em espaços específicos e optei por seguir meus parceiros Lino e Lopes nas atividades em que atuavam cotidianamente, compreender o trabalho que realizavam, sua natureza e o público envolvido, e oferecer ajuda de acordo com as minhas limitações.

Desta forma, tomei como ponto de partida a ação coletiva realizada pelos parceiros de pesquisa que evidenciavam transformação e requalificação de espaços na Maré. Para a arquiteta britânica Ann Thorpe (2011), a ação coletiva pode representar formas de resistência que desafiam poderes institucionais e outras formas de autoridade. Ao pensar na ação coletiva como meio para a transformação do território da Maré, formulei alguns questionamentos como pontos referenciais, de maneira que me auxiliassem durante cada visita in loco:

Que atividades realizadas pelos parceiros da Redes da Maré transformam e qualificam os espaços por eles ocupados e como elas o fazem? Quais são as características principais de cada um dos espaços ocupados e quais são as suas diferenças?

O que pode emergir de processos colaborativos entre eu, designer-pesquisadora, e ativistas locais parceiros durante atividades que transformam espaços da favela? Que ferramentas facilitam esse processo? Quais são as potencialidades e os maiores desafios? 
O que o design entende por participação em projetos realizados pela sociedade civil? O que designers que atuam e já atuaram em projetos participativos em espaços urbanos podem relatar como experiência?

A partir destas perguntas, apresento um apanhado de reflexões levantadas em experiências e aprendizados que partem da minha perspectiva como pesquisadora após uma série de vivências na Maré ao longo dos anos de 2016 e 2017. Nesta trajetória me apoiei em diversas referências teóricas provenientes de campos distintos do conhecimento que foram além do design e da arquitetura, tais como antropologia, sociologia e pedagogia, e levei em consideração fontes primárias e secundárias que alimentaram o trabalho.

Contudo, o cerne está nas vivências em campo, pois somente nelas pude compreender a aplicação de abordagens do design e da arquitetura na prática, o que se compreende por design na perspectiva das pessoas com quem estive em contato e como a minha figura era reconhecida ali. Para tanto, reconheço e legitimo aqui cada uma das pessoas com quem troquei informações e escutei histórias como fontes primárias do trabalho, pois sem elas a teoria utilizada seria esvaziada e desconectada.

As leituras, sempre complementares às trocas em campo, me auxiliaram a compreender o que vem sido amplamente discutido no âmbito acadêmico em design, arquitetura e urbanismo, dentro e fora do Brasil. Ao mesmo tempo, a cada experiência, diálogo e interação na Maré, ficava evidente para mim como estas áreas de estudo eram alheias àquele contexto, visto que eram associadas principalmente à funções solucionadoras de problemas e embelezadoras de coisas e espaços. Compreendi na troca contínua entre estar imersa na literatura e estar imersa em campo, como vivenciar aquele ambiente era uma grande oportunidade de aprendizado para se compreender a minha postura em relação às decisões urbanas e projetuais, o reflexo da história política, social e cultural no campo do design nos dias atuais, o emprego da colaboração nas práticas projetuais contemporâneas, e os caminhos para os quais a cultura do projeto está se enveredando. Todas essas informações são apresentadas no primeiro capítulo da dissertação "O design atento ao território e sua postura ativista".

Uma vez que o trabalho tomou uma postura flexível, o estado da arte da pesquisa é apresentado ao longo dos capítulos entre narrativas sobre a Maré, visto que cada mo- 
mento foi suportado por autores específicos em temas distintos e de épocas diferentes. Dois eixos estruturais serviram de base para a organização teórica da pesquisa: (1) A Redes da Maré, suas formas de ação e seu contexto no espaço urbano, e (2) a relação do design com a cidade, seu caráter social e colaborativo na prática contemporânea.

No primeiro eixo, abraço uma literatura que me auxiliou a compreender a construção social do espaço na Maré, sua formação histórica, o nascimento da iniciativa, seus desdobramentos no território, seus atores e suas formas de agir, improvisar, usar e transformar espaços no local. No segundo eixo, utilizo uma literatura que abarca discussões acerca do papel da profissão e do profissional, a relação de projetos de design com foco social e no espaço urbano, referências históricas que envolvem design colaborativo, bem como atuais abordagens de design que envolvem colaboração, sua aplicação e impacto no espaço urbano.

Ao total, são quatro capítulos que foram divididos pelos títulos: (1) O Design atento ao território e sua postura ativista, (2) Contextualização: o Complexo da Maré e suas lideranças comunitárias, (3) Processos de experiências e aprendizados na Maré, (4) As diferentes formas de colaboração e o desafio da co-criação.

O primeiro capítulo ilustra o contexto cultural, político, social e econômico em que este trabalho foi inserido, a postura política adotada para realizá-lo e a sua relevância para o campo do design e da arquitetura atualmente, dentro e fora do Brasil. O texto conta com aportes teóricos do autor equatoriano Alberto Acosta (2016) e suas críticas a noção de desenvolvimento moderno; do economista indiano Amartya Sen (2010) e sua perspectiva de desenvolvimento como liberdade; do antropólogo colombiano Arturo Escobar (2016) e a crise do desenho moderno e as diferenças de foco entre o design para o Norte Global e Sul Global; dos designers Aloisio Magalhães (1998; 2014) e Richard Buchanan (1992) sobre a responsabilidade social do design em problemas complexos; os indianos Rahul Mehrotra (1998) e Gayatri Spivak (2010) e suas reflexões para uma atitude atenta ao contexto durante a prática; Jacques Ranciére (2010), Paola Jacques e Fabiana Britto (2015) sobre a relevância de se reconhecer outras formas de inteligência e alteridade; Adam Thorpe e Lauren Gamman (2011) e a atitude responsiva no design; Carl Di Salvo (2009), Elizabeth Sanders e Pieter Stappers (2008), Johan Redström (in Gunn; Donovan, 2013) e outras referências que englobam os último trin- 
ta anos sobre o papel do profissional nos âmbitos sociais, informais e colaborativos; Zoy Anastassakis e Barbara Szaniecki (in Smith et al., 2016) em práticas coletivas no design; e Ann Thorpe (2011), Tau Ulv Lenskjold, Joachim Halse e Sissel Olander (2015) e Guy Julier (2013) acerca de uma postura ativista no design.

No segundo capítulo faço uma breve contextualização do Complexo da Maré, sua história e formação, sua separação na metrópole do Rio de Janeiro, a construção social do seu espaço, suas dinâmicas sociais atuais e seu cotidiano, suas potencialidades como território informal, porém articulado e vivo. Além disso, faço uma introdução completa sobre a organização da Redes da Maré, como descrito no primeiro ponto mencionado na estrutura de Malinowski, o qual apresento a anatomia da organização, sua história, suas estruturas hierárquicas, seus coordenadores e atores, sua atuação e articulação no território e os espaços que utilizam e seus atributos. Termino o capítulo abordando sobre a transição da pesquisa de investigação ao Coletivo Maré para Redes da Maré.

Para tanto, me apoio em literaturas de Paola Jacques (in Varella et al., 2002) que atuou e estudou o território da Maré; Ermínia Maricato (1996) e Marilena Chauí (2001) que envolvem a produção do espaço urbano brasileiro; Sérgio Abrahão (2008) e a relação do espaço público e o espaço político; Alba Zaluar e Marcos Alvito (2006) acerca da história e construção de identidade da favela; Michel De Certeau (2014) e o espaço como lugar praticado; Milton Santos (2014) e o entendimento do território em rede; Marcos Rosa (2015) e a articulação e apropriação do território em meio as infraestruturas de larga escala e a noção de espaços coletivos; e Mehrotra (2008) e a concepção de cidades cinéticas. A respeito da Redes da Maré (2018), me debruço sobre conteúdos como o site da iniciativa, produções bibliográficas de Eliana Sousa Silva (2015), fundadora da organização, bem como a publicação Solos Culturais, desenvolvida por Caio Gonçalves Dias e Jorge Luiz Barbosa (2013), o Observatório de Favelas (2018), organização focada em estudos das favelas metropolitanas e o Guia de Ruas da Maré (2014) e suas informações geográficas, sociais e históricas. Conto também com contribuições de teses e dissertações que ampliaram o conhecimento sobre a iniciativa e a própria Maré, especialmente em referências históricas.

No terceiro capítulo apresento o processo que vivenciei na Maré, as abordagens em que me apoiei e, em seguida, três importantes etapas: (3.1) 'visitas ocasionais', a qual 
discorro em parte sobre o segundo ponto de Malinowski, além das minhas primeiras aproximações e meu entendimento sobre o contexto; (3.2) 'imersão no território', item em que narro sobre a minha vivência durante o mês que acompanhei o trabalho da iniciativa in loco e abordo a outra parte do segundo e, também, integralmente o terceiro tópico de Malinowski; por fim, a etapa (3.3) 'da observação para a ação', momento em que há uma transição entre a minha postura como observadora participante para propositora no espaço do Centro de Artes da Maré e narro duas atividades colaborativas vivenciadas, suas reflexões e questionamentos. Ao final de todas as etapas faço uma breve reflexão sobre a prática colaborativa e seus desafios.

Neste capítulo me apoio inicialmente em abordagens que utilizei e com que me envolvi: o design anthropology, por meio de conteúdos organizados por Wendy Gunn (et al., 2013; Donovan, 2012), Rachel Smith (et al., 2016) e outros, o codesign, por meio de teses e artigos desenvolvidos no Center for Codesign Research (CODE), o design social participativo, por meio de conteúdos de Rita Couto (1991). Em seguida, nas etapas vivenciadas em campo, uso aportes da antropologia como Marcel Mauss (2003) e as técnicas do corpo; Michel De Certeau (2014) e as táticas urbanas; William Foote-Whyte (in Guimarães, 1975) e a técnica de observação participante; Tim Ingold (2016) e Caroline Gatt (in Gunn et al., 2013) sobre trocas de correspondência entre designers e ativistas e posturas para uma outra prática de design e antropologia;

No quarto capítulo retomo as reflexões levantadas das etapas descritas no capítulo anterior, apresentando diferentes camadas em que a colaboração foi interpretada no processo vivenciado. Estas camadas são apresentadas em subtópicos e trazem os aspectos relevantes evidenciados durante a pesquisa. Na sequência apresento os desdobramentos do trabalho em campo e algumas observações posteriores ao processo narrado. Finalmente, coloco reflexões e observações levantadas em duas entrevistas realizadas com a pesquisadora Chiara Del Gaudio sobre o tema da colaboração em design, assim orientando o fechamento do trabalho.

Alguns autores são fundamentais neste capítulo: da antropologia conto com Arturo Escobar (2016), abordando sobre vernacular; Tim Ingold e Elizabeth Hallam (2007) e as diferentes formas de improvisação; Tim Ingold e Caroline Gatt (in Gunn et al., 2013) sobre a concepção de foresight e a correspondência; Marcel Mauss (2003) e seu ensaio 
sobre a dádiva; e Michel De Certeau (2014) e as táticas e estratégias. Da sociologia conto com Richard Sennett (2013a; 2013b) e seus conteúdos envolvendo o aprendizado colaborativo nas práticas manuais e os rituais de cooperação; e Bruno Latour (2001; 2009) e a sua teoria ator-rede no entendimento das articulações no território e a noção de projetar coletivamente. Da educação conto com Paulo Freire (1996) e sua atenção ao diálogo e a autonomia; Do design e da arquitetura conto com Maria Cecilia Loschiavo dos Santos (2003) no que se refere ao design espontâneo diante de condições precárias urbanas; Chiara Del Gaudio, Carlo Franzato e Alfredo de Oliveira (2014) e o tempo como fator relevante em processos de colaboração; Rita Couto (1991) e o enfoque social no design; Sophie Wolfrum e Nikolai Brandis (2015) e suas discussões sobre urbanismo performativo; Kristina Niedderer (2007) e sua concepção sobre o objeto performativo; e por fim Zoy Anastassakis e Bárbara Szaniecki (in Smith et al., 2016) e as concepções de protótipo e provótipo. Somado a esses utilizo como referência algumas exposições, dissertações de mestrado e teses de doutorado que circulam os temas debatidos. 


\section{CAPÍTULO 1}

\section{O design atento ao território e sua postura ativista}

Antes de iniciar a narrativa sobre a Maré e as vivências por lá percorridas, reconheci necessário ilustrar os contextos cultural, político, social e econômico em que este trabalho foi inserido, a postura política adotada, a relevância atual da pesquisa, dentro e fora do Brasil, diante dos campos do design e da arquitetura e o tipo de design que este trabalho se baseou para realizar processos. Em um momento de luta e resistência, em que educação pública vem sendo corroída pouco a pouco e há ameaças de cortes no âmbito da pesquisa e desenvolvimento ${ }^{22}$, realizar pesquisas que ultrapassam os muros da universidade é um grande desafio.

Este trabalho está situado em um contexto de emergência, "que reclama a importância das práticas de representação como espaços de disputas abertas para imaginar futuros diferentes da desigual situação presente" (Anjos in Travessias, 2017). Como respondemos a crise? Após anos de buscas pela desconstrução e fragmentação de discursos modernos, já concluímos que o progresso e o racionalismo não podem sozinhos solucionar questões complexas humanas. Em tempos de turbulência política e econômica, tal qual coloca a pesquisadora Donna Haraway (2016), em que agendas hegemônicas segregacionistas se impõem e querem homogeneizar diferenças culturais para atender demandas mercadológicas (Escobar, 2007) utilizando o medo, o ódio e o consumismo

\footnotetext{
22. O jornal $\bigcirc$ Globo publicou no início do ano de 2018 sobre a ameaça do Conselho Nacional de Desenvolvimento Científico e Tecnológico (CNPq) de corte de até cem mil bolsas de estudo para pesquisadores até o fim de 2017 por conta de corte de repasses do Governo Federal, fato que amedronta universidades e pesquisadores de todo o país. Disponível em: <https://oglobo.globo.com/sociedade/ educacao/ameaca-de-corte-no-financiamento-do-cnpq-para-100-mil-bolsas-preocupa-cientistas-21667267\#ixzz57Hz59H6U>. Acesso em: 10 Fev. 2018.
} 
massificado, "até quando vamos esperar que o progresso tecnológico resolva nossos enormes problemas?" (Acosta, 2016, p. 36).

Para o equatoriano Alberto Acosta (2016), a raiz de nossos problemas está na concepção da palavra desenvolvimento - seja ele econômico, social, industrial ou de outra natureza. $O$ autor advoga que o discurso totalizante promovido pela palavra apenas traveste nossa posição de colônia, periférica em relação à cultura eurocêntrica e inferior em termos sociais e econômicos. Para ele ${ }^{23}$, enrijecemos nossa capacidade de visão acerca das virtudes e atitudes comunitárias tradicionais, de modo que hoje

\begin{abstract}
negamos inclusive nossas raízes históricas e culturais para modernizar-nos imitando os países adiantados. Assim, negamos as possibilidades de uma modernização própria. O âmbito econômico, visto a partir da lógica da acumulação do capital, domina o cenário. A ciência e a tecnologia importadas normatizam a organização das sociedades. Neste caminho - de mercantilização implacável - aceitamos que tudo se compra, tudo se vende. Para que o pobre saia de sua pobreza, o rico estabeleceu que, para ser como ele, o pobre deve agora pagar para imitá-lo: comprar até seu conhecimento, marginalizando suas próprias sabedorias e práticas ancestrais.
\end{abstract}

Em outra perspectiva, oposta e complementar ao mesmo tempo, o economista indiano Amartya Sen (2010, p. 16) vai por outro caminho, no qual compreende o desenvolvimento como um "processo de expansão das liberdades reais que as pessoas desfrutam". Sen ${ }^{24}$ compreende que para atingir o tão sonhado desenvolvimento é necessário que sejam removidas "as principais fontes de privação de liberdade: pobreza e tirania, carência de oportunidades econômicas e destituição social sistemática, negligência dos serviços públicos e intolerância ou interferência excessiva de Estados repressivos".

Para o autor ${ }^{25}$ uma visão genérica contra os mercados é tão incoerente quanto ir contra o diálogo entre as pessoas. "A liberdade de trocar palavras, bens ou presentes não necessita de justificação defensiva com relação a seus efeitos favoráveis, mas distantes; essas trocas fazem parte do modo como os seres humanos vivem e interagem em sociedade".

\footnotetext{
23. Ibid., p. 51-52.

24. Sen, 2010, loc. cit.

25. Ibid., p. 20.
} 
Já nas ciências sociais, Guattari (2012, p. 12) coloca uma posição mais holística em relação aos dois autores, quando afirma que há um paradoxo no desenvolvimento contínuo dos meios técnico-científicos. Para o autor, o avanço técnico e científico vive a dicotomia entre a sua capacidade de resolver problemáticas ecológicas e sociais, mas, ao mesmo tempo, a incapacidade das forças de poder de se apropriar de tais meios e torná-los operativos.

Esta compilação de visões propicia uma orientação inicial sobre a postura política adotada neste trabalho, que não ambicionou travar um caminho unívoco, ou advogar por uma crítica pronta, mas sim enxergar múltiplas perspectivas. Essas me auxiliaram no reconhecimento das potencialidades existentes na Maré, um território de contradições, que cotidianamente forja formas de agir descolonizadas da 'cidade formal' ${ }^{26}$, por meio da improvisação, habilidades locais, cooperação e a informalidade espacial. Simultaneamente, os constantes conflitos dificultam que o território adquira emancipação a fim de explorar e ampliar suas qualidades e atributos e fomentar suas atividades culturais, sociais e econômicas.

Ao transpor estas perspectivas de outras áreas do conhecimento para o âmbito do design e da arquitetura, vivemos um momento em que somos duplamente afetados: seja em nossa incapacidade de construir uma visão plenamente autóctone na prática projetual, ou na falta de reconhecimento do campo, em que ainda somos vistos como prestadores de serviço ou embelezadores de coisas, espaços e pessoas ao invés de profissionais engajados politicamente na promoção de qualidade de vida urbana e social.

Quanto mais lidamos com dificuldades trabalhistas e o baixo reconhecimento dos dois ofícios, maior é a complexidade para engajar esforços em atuações focadas em diferenças sociais e problemas cotidianos urbanos e para ter uma atitude responsiva no trabalho que vai além de lutar pelos nossos direitos. Proveniente de um contexto privilegiado, ingressei na PUC-Rio em 2009, momento em que me deparei pela primeira vez com uma maior diversidade social e econômica no espaço de aprendizado. Hoje, com as inúmeras ameaças de cortes de investimento para educação, percebo o cenário atual em crise, o que pode afetar diretamente na produção acadêmica a espaços externos à favela que são planejados e organizados por uma ordem centralizadora, o Estado. 
respeito da cultura material brasileira, o desenvolvimento rural e urbano do país, e o empoderamento e a autonomia em espaços desprivilegiados.

Somado a isso, a segregação existente entre as formas de se pensar o projeto ainda impede que os campos do design e da arquitetura sejam mais unidos e complementares. Na PUC-Rio, adquiri uma visão projetual humana, plural, participativa e situacional, que me permitiu enxergar além da minha capacidade criativa e solucionadora de problemas, realmente levando em conta os usuários no processo de projeto, porém desprovida de uma consciência política urbana, especialmente com relação a políticas públicas e o planejamento urbano. Quando ingressei no mestrado na FAU-USP, tive o privilégio de participar de aulas sobre planejamento urbano, paisagismo e habitação, que focavam diretamente na construção e transformação de um espaço urbano mais justo e igualitário, porém ainda pouco envolvido em uma visão centrada na figura humana e a sua experiência na cidade. A complementariedade acadêmica de ambas as escolas permitiu que o meu trabalho crescesse imensamente e me fez enxergar como ambos os lados possuem grupos que estão caminhando para um mesmo propósito: promover qualidade de vida na cidade por meio de uma prática de projeto que reconhece o outro, dá a ele voz de expressão e o percebe como ator no processo projetual.

Após participar da conferência internacional 'Design For Next', organizada pela European Academy of Design ${ }^{27}$, e assistir diversas apresentações de pesquisadores de diferentes países, pude notar que os propósitos encontrados nas duas escolas que estudei têm se valorizado cada vez mais no design e na arquitetura. Esta valorização ocorre em inúmeros projetos e investigações atuais, especialmente entre novas gerações de designers e pesquisadores que reconhecem a necessidade de compartilhar o processo projetual com atores do contexto (Sanders; Stappers, 2008). Embora participação e a colaboração nos campos projetuais não sejam práticas recentes de estu$\mathrm{do}^{28}$, profissionais do século XXI têm estado mais próximos e atentos às experiências

27. O European Academy of Design é uma organização focada em pesquisa e desenvolvimento em design desde 1994. Em 2017 a organização realizou a conferência Design For Next na Faculdade de Arquitetura Valle Giulia na universidade Sapienza em Rosa, Itália. Para mais informações ver: <http://www.designfornext.org/about.html>. Acesso em: 18 Set. 2017. 
co-criativas, especialmente para futuros mais resilientes e sustentáveis ${ }^{29}$. Ou como colocam os pesquisadores Elizabeth Sanders e Pieter Stappers ${ }^{30}$,

As novas gerações estão tendo um tempo mais fácil em distribuir e compartilhar o controle e a propriedade. Essa mudança de atitude é amplamente possível porque a internet deu voz a pessoas que anteriormente não faziam parte das conversas. Mas demorará algum tempo até que a cultura predominante aceite o compartilhamento de ideias igualitárias. Também é difícil para muitas pessoas acreditar que são criativas e se comportam de acordo. O co-design requer uma iniciativa criativa por parte de toda a equipe: pesquisadores, designers, clientes e as pessoas que, em última instância, se beneficiarão da experiência de projetar junto. ${ }^{31}$

Reconhecendo-me parte desta nova geração de designers engajada na coprodução da cidade a partir da ação coletiva experimental com ativistas da Maré, advogo a seguir por outra forma de fazer design, descolada das práticas tradicionais e alinhada ao contexto complexo presente. Permeando esta argumentação, faço uma breve contextualização crítica da atuação projetual e apresento aspectos que sugerem a relevância deste trabalho no âmbito do design e da arquitetura diante do momento atual de crise.

apresenta um levantamento histórico das principais formas de participação no campo, com referências de Nigel Cross, que discute a participação no projeto desse 1975, o Symposium for Social Need, desenvolvido em 1976 pela Royal College of Art, os adventos do Participatory Design, originário da Escandinávia, entre outros. No âmbito da arquitetura, Marcos Rosa (2015) apresenta em sua tese um panorama sobre participação em arquitetura e urbanismo desde a década de 1960, dando relevância aos trabalho de Sérgio Ferro, Flávio Império e Rodrigo Lefebvre, do 'Grupo Arquitetura Nova', os trabalhos de Nabil Bonduki e Raquel Rolnik na década de 1980, que pensavam na geografia social urbana e o papel das assessorias técnicas, tais como USINA e Peabiru.

29. Cf. Niedderer, K. Mindful design as a driver for social behaviour change. Proceedings of the IASDR Conference 2013. Tokyo, Japan: IASDR, 2013.

30. Sanders; Stappers, op. cit., p. 9

31. No original: "The new generations are having an easier time in distributing and sharing the control and ownership. This change in attitude is largely possible because the internet has given a voice to people who were previously not even a part of the conversations. But it will take some time before the predominant culture accepts egalitarian idea sharing. It is also difficult for many people to believe that they are creative and to behave accordingly. Co-designing requires creative initiative on the part of the entire team: researchers, designers, clients, and the people who will ultimately benefit from the co-designing experience". 


\subsection{0 descolamento das práticas tradicionais de design: qual prática estamos buscando?}

Enquanto o Norte Global busca maneiras experimentais e conscientes de desafiar questões sócio-políticas relacionadas a futuros mais sustentáveis, o Sul Global ainda se vê desafiado por conflitos sociais de habitação, compartilhamento de espaço público, invasão e exploração de terras e falta de autonomia social, como abordado por Escobar (2017, p. 32-63) em seu recente artigo. Em países latino-americanos, jovens designers estão envolvidos em práticas de design colaborativo mais conscientes dos resultados de se realizar coletivamente, ao invés de levar seus usuários como meros objetos passivos de estudo ${ }^{32}$.

Para Escobar (2016, p. 50-52) "o design está inextricavelmente ligado às decisões sobre o tipo de vida que vivemos e os mundos onde os vivemos"33. O autor afirma que estamos em um momento em que as atividades projetuais estão se abrindo mais para campos das ciências humanas, tais como a geografia e a antropologia, de modo que profissionais vêm aplicando

novos métodos [que] enfatizam a investigação nas fases iniciais do processo, com o designer como facilitador e mediador ao invés de um especialista; concebendo o design como eminentemente centrado no usuário, participativo, colaborativo e radicalmente contextual; eles tentam tornar inteligíveis e conhecedores os processos e estruturas que nos cercam, para induzir aos usuários uma alfabetização ecológica e de sistemas; etc. Acima de tudo, (...), há uma tentativa de construir visões culturais alternativas como motores da transformação social através do design. ${ }^{34}$

32. Sanders; Stappers, op. cit., p. 11.

33. No original: "El diseño está inextricablemente ligado a las decisiones sobre el tipo de vidas que vivimos y los mundos donde las vivimos".

34. Ibid., p. 52. No original: “Los nuevos métodos destacan la investigación en las fases iniciales del proceso, com el diseñador como facilitador y mediador más que como experto; conciben el diseño como eminentemente centrado en el usuario, participativo, colaborativo y radicalmente contextual; tratan de hacer inteligibles y cognoscibles los procesos y estructuras que nos rodean, para inducir en los usuarios un alfabetismo ecológico y de sistemas; etcétera. Por encima de todo, volviendo a la cuestión normativa, existe un intento por construir visiones culturales alternativas como motores de transformación social a través del diseño". 
No contexto do Sul Global, mais especificamente no Brasil, a desigualdade e as questões sociais complexas são problemas da vida cotidiana. Os 'problemas complexos' (da língua inglesa 'wicked problems') elucidados por Rittel e Webber (1973) e discutidos por Richard Buchanan (1992), ainda prevalecem e representam desafios para designers que almejam trabalhar ou pesquisar com contextos desiguais, seus habitantes, suas demandas, sonhos e esperanças.

Cinquenta anos atrás, antes mesmo de Buchanan, Aloisio Magalhães (1998, p. 8-12) abordou sobre a responsabilidade social no design ao questionar: o que o desenho industrial pode fazer pelo país? Acreditava-se que estes mesmos problemas seriam resolvidos por meio da cultura popular articulada a prática projetual (Magalhães in Leite, 2014). Nas palavras de Escobar (2016, loc. cit.) "muitas vezes o objetivo dos designers era melhorar os bens produzidos em massa e a qualidade de vida das pessoas através do uso de novos materiais e técnicas”35.

No entanto, o cenário enfrentado hoje - carregado de heranças políticas e sociais do período ditatorial e da cultura projetual moderna - sequer aproxima-se ao que o designer pernambucano havia pensado para designers brasileiros, isto é, mais democrático e atento as questões sociais e culturais nacionais. Além do design no país não ser considerado um meio para viabilizar soluções democráticas, especialmente para estratos sociais desprivilegiados, muitos profissionais saem a campo para trabalhar com pessoas comuns e seus problemas e demandas da vida cotidiana, mas sem preparação para se envolver no domínio público.

Ao passo que designers lidam cada vez mais com resistências cotidianas e comportamentos interpessoais, observei, por meio desta pesquisa de mestrado, que precisamos compreender melhor nossos atos em relação aos diferentes sistemas sociais. Antes de engajarmos puramente em atitudes propositivas, é necessário reconhecer a alteridade existente nas trocas e colocar a nossa perspectiva como projetista sob parâmetros de

35. Escobar, 2016, loc. cit. No original: "muchas veces el objetivo de los diseñadores era mejorar los bienes producidos en masa y la calidad de vida de la gente a través del uso de nuevos materiales y técnicas. En estas prácticas es posible ver una preocupación incipiente con la relación entre el diseño y la política (...)". 
diferença, em que todos os diferentes tipos de inteligência são legitimados com o mesmo valor, tal qual foi abordado pelo filósofo francês Jacques Ranciére (2002).

Compreender a alteridade está na capacidade de reconhecimento do outro, de maneira que os diálogos sejam horizontais tanto no lado de cá quanto de lá, ainda que as forças de poder tenham que ser repensadas. O designer Gui Bonsiepe (2011, p. 38) sugere que a alteridade é a "palavra que significa colocar-se no lugar do outro na relação interpessoal, com respeito e consideração, valorização etc. É um princípio filosófico que significa trocar seu próprio ponto de vista pelo do outro".

Realizar ações pautadas na alteridade é ainda um desafio em processos de colaboração, especialmente porque designers e arquitetos são ainda celebrados como as figuras portadoras da inovação, especialistas, capazes de solucionar problemas de vários tipos e escalas. Maria Cecilia Loschiavo dos Santos (2003) sugere que além do conceito de design pautado no culto dos produtos e em sua literatura histórica, "há outro sentido (...) que corresponde às práticas realizadas em bases espontâneas por pessoas desprovidas (...) visando sua sobrevivência. Não se trata mais da celebração do star design, mas sim a celebração da habilidade humana de fazer design, mesmo sob condições extremamente difíceis".

Compreende-se por este raciocínio que uma educação para atenção necessária para a leitura de situações complexas, como advogada por Ingold (2001), ainda é pouco desenvolvida na formação de profissionais, ou como coloca a pesquisadora Lucrécia Ferrara (2002, p. 52) ao referir-se diretamente ao âmbito do projeto que:

O projeto mostra ao desenho sua dimensão social interessada e interesseira que lhe permite superar os condicionantes da tecnologia dos materiais e seus procedimentos. Esta dimensão social, mais uma vez, transforma competência do saber fazer no desempenho de saber por que se faz, com a atenção flexível daqueles que estão à espreita, observando os caminhos inventivos disponíveis; nessa tarefa o projeto é claramente atenção, observação e comparação entre projetos e usos.

A necessidade de afastamento das práticas racionalistas no design é evidenciada a partir da constante mudança no papel de profissionais, especialmente por meio de práticas contínuas de colaboração, o que requer uma revisão crítica sobre os impac- 
tos gerados em ações sociais e participativas no design. A socióloga indiana Gayatri Spivak (2010, p. 43) sugere que "a prática radical deve estar atenta a esse duplo sentido do termo representação, em vez de tentar reinserir o sujeito individual por meio de conceitos totalizadores de poder e de desejo". Considerando suas palavras, reconhecemos que não se trata de desenvolver apenas processos de design, envolvendo colaboração e mudança de comportamentos. Trata-se de evitar a inserção de interpretações afirmadas pelo status quo como o melhor caminho para alcançar progresso, crescimento e desenvolvimento ${ }^{36}$ e potencializar as ações que já estão envolvidas com preocupações reais, questões existentes já aprofundadas ou emergentes não formuladas.

Todavia, é possível compreender o modo como o modelo econômico capitalista sempre afetou a nossa consolidação cultural, principalmente a popular, de modo que fôssemos treinados a nos espelhar prioritariamente nos estilos de vida europeu e estadunidense. Segundo Canclini ${ }^{37}$, "as culturas subalternas são impedidas de um desenvolvimento independente ou alternativo, pois reorganizam sua estrutura social e linguagem de acordo com a produção e o consumo, para se adaptarem ao desenvolvimento capitalista" e ainda "(...) as culturas subalternas populares são resultado de uma apropriação desigual do capital cultural, uma elaboração própria de suas condições de vida e uma interação em conflito com os setores hegemônicos" 38 .

O mesmo vale para a construção da formação pedagógica brasileira em design, que foi apoiada em referências alemãs de ensino em design. José Luiz Mendes Ripper, professor emérito da PUC-Rio, conta que até o horário das aulas e atividades de laboratório eram idênticas às da Bauhaus, ao passo que nem o clima tropical brasileiro era levado em consideração na formulação acadêmica ${ }^{39}$. Magalhães (1998, p. 11), ator relevante na luta por um ensino de design verdadeiramente brasileiro, especialmente nas décadas de 1960 e 1970 como professor na ESDI/UERJ, coloca que "a carência de originalidade deu lugar à exuberante presença da cópia e o gosto mimético por outros valores culturais".

36. Escobar, op. cit., p. 44-45.

37. 1989, passim, tradução nossa.

38. No original: "la particularidad de las culturas populares no deriva sólo de que su apropiación de lo que la sociedad posee es menos y diferente; también de que el pueblo genera en su trabajo y su vida, formas específicas de representación, reproducción y reelaboración simbólica de sus relaciones sociales". 39. Cf. Montuori in Braga; Ferreira, 2017, p. 79-99. 
Com base nestas constatações e diante de um contexto de disparidades sociais de larga escala e de crise energética e ambiental como pautas constantes, surgem as questões: qual o papel social de designers brasileiros nesta atual interface sócio-econômico-política turbulenta? Como estes podem agir e contribuir para a sua cidade como profissionais e cidadãos? Ou como Fezer (2010, tradução nossa) coloca:

Ao fazer referência à 'cidade', tanto como processo e como o cotidiano - como uma dimensão concreta da realidade - o propósito de projeto será refletido novamente: como seria o design se fosse inspirado por uma abordagem aberta, processual, micropolítica, intervencionista, comunicativa e participativa que se relaciona com a vida urbana cotidiana? Seria destinado a ser apenas um elemento na colonização mercantilizada dos espaços sociais, ou poderia ser uma ferramenta estratégica com um caráter político e social que pode contribuir essencialmente para uma cidade social? $4^{\circ}$

O design, reconhecido frequentemente no campo da ciência e tecnologia, vai muito além do processo de projeto de um produto (físico ou digital), pois se trata de uma ciência social aplicada ${ }^{41}$. Este ponto de vista, aqui adotado, quer evidenciar que o projeto de design deve levar em consideração as vivências, demandas, necessidades e desejos dos usuários, valorizando sua história e a cultura local a fim de quebrar com as imposições de consumo massificantes colocadas pela mídia e o mercado.

No entanto, muito além de propor e executar soluções direcionadas para usuários, questiono o papel e a responsabilidade social da profissão no que diz respeito à proposição participativa e inclusiva, especialmente em contextos de complexidades sociais, como o da Maré. Magalhães (1965 in Leite, 2014, p. 36-37), ao abordar a posição do artista contemporâneo diante de mudanças sociais na década de 1960, afirmou que "a posição do artista em nosso tempo teria que ser revista. No momento, o que interessa

40. No original: "how would design look if it were inspired by an open, processual, micro-political, interventionist, communicative, and participatory approach that relates to everyday urban life? Would it be destined to be merely an element in the commodified colonization of social spaces, or could it be a strategic tool with a political and social character that can make an essential contribution to a social city?".

41. Dado evidenciado pela Professora Dra. Maria Cecilia Loschiavo durante sua aula na disciplina

'O Design Posto em Questão' na FAU-USP em 28 de agosto de 2015. 
é a larga informação, o coletivo. Não tem mais sentido no nosso mundo o artista fazer objeto único, o quadro desligado do contexto social no qual ele vive" ${ }^{\prime \prime 2}$.

Por uma perspectiva semelhante, direcionada a atuação de profissionais em contextos urbanos desiguais, o arquiteto e pesquisador indiano Rahul Mehrotra ${ }^{43}$ (1998, p. 7, tradução nossa) é claro quando fornece uma perspectiva sobre a distância dos profissionais e seu papel em ambientes urbanos complexos durante seus estudos e projetos em Mumbai:
Arquitetos e designers que trabalham nestes contextos urbanos agora estão lidando com uma gama inteira de problemas e questões sociais, culturais e econômicos que muitas vezes são estranhos às suas profis- sões. Na práxis convencional, o arquiteto profissional não se envolve neste conjunto mais amplo de questões, mas opta por operar com a es- pecificidade de um local, no processo, muitas vezes se desconectando do contexto de prática maior. $\mathrm{O}$ crescimento urbano sem precedentes é um desafio para os profissionais de design para redefinir seu papel na sociedade. ${ }^{44}$

Para ambos os autores, sejam artistas, designers ou arquitetos, há uma urgência de participação e inserção no contexto social e político, de forma que suas atividades evitem práticas isoladas, descontextualizadas e vazias. Lidamos com um contexto no qual designers enfrentam a necessidade de integração por outros caminhos, que vão além do desenho técnico e industrial - limitado para profissionais de campos criativos e majoritariamente importado de países centrais. Assim, vale-se da ideia de que o campo do design é estruturalmente pautado em atividades sociais, já que está inserido socialmente, seja na sua forma institucionalizada ou popular (Cardoso, 2010, p. 51). Todavia, a troca entre os designers, a cidade e as práticas populares ainda precisa avançar muito no Brasil, como coloca Magalhães (1998, p. 11):

42. Ibid., p. 37..

43. Cf. Mehrotra, R. Working in Bombay: The City as Generator of Practice. Anytime, June, p. 64-69, 1998. Disponível em: <http://www.rmaarchitects.com/essays/working-in-bombay.pdf>. Acesso em 11 Out. 2016.

44. No original: "Architects and designers working in these urban contexts are now dealing with an entire gamut of social, cultural, and economic issues and problems that are often alien to their professions. In conventional praxis the professional architect does not engage in this wider set of issues but rather chooses to operate with the specificity of a site, in the process often becoming disconnected from the larger context of practice. Unprecedented urban growth is challenging design practitioners to redefine their role in the society". 
(...) nossa posição no domínio do Desenho Industrial pode oferecer, através da ótica abrangente que o modelo [econômico e político] nos proporcionou, condições de reconceituar a própria natureza da atividade que nasceu voltada apenas para a solução de problemas emergentes da relação tecnologia/usuário em contextos altamente desenvolvidos, a bitola estreita da relação produto/usuário nas sociedades eminentemente de consumo.

Este raciocínio também ganhou corpo com a quebra do tradicional formato de se fazer design, que segue a regra na qual profissionais projetam e depois usuários usam, para a inserção do usuário como parte do projeto, dando voz a ele para sugerir, opinar, testar e construir junto. Este raciocínio, ampliado pelo pesquisador Johan Redström (in Gunn; Donovan, 2012, p. 83, tradução nossa) sugere:

Ao passo que o design e a pesquisa em design certamente atravessaram um longo caminho desde os primeiros dias do desenho industrial para produção em massa e consumo em massa, nós ainda lutamos com a articulação de relações entre projetar e usar que se diferencia significativamente de um entendimento que primeiro designers projetam, depois usuários usam. ${ }^{45}$

Assim, este trabalho direcionou seu olhar para um design voltado para práticas sociais e democráticas, expandidas para além do projeto técnico industrial mercadológico e aproximadas das realidades sociais do país e da cultura popular do centro às bordas. Este viés representa uma reorientação do foco tradicional e cultural do campo, que migra do seio das atividades econômicas neoliberais (Julier, 2013) para uma atitude que estimula junto aos usuários "mudanças que venham de dentro" e possam "ensaiar novos cenários" (Lenskjold et al., 2015).

Aproximar designers de iniciativas comunitárias permite o reconhecimento das ações realizadas por grupos como a Redes da Maré no âmbito do projeto, não apenas gerando visibilidade à sua atuação na transformação urbana e social, mas na promoção de um intercâmbio de aprendizados. Ao mesmo tempo, tal aproximação abre espaço para que cada vez mais designers atuem de forma integradora, reconhecendo o saber fazer verna-

45. No original: "whereas design and design research certainly have come a long way since the early days of industrial design for mass-production and mass-consumption, we still struggle with articulation of relations between design and use that differ significantly from an understanding that first designers design, then users use". 
cular de transformação do espaço urbano que já existe e já está consolidado. Desta forma, advogo por uma prática de design que visa alcançar a emancipação dos usuários nos processos projetuais, em oposição à ideia que coloca a prática apenas como uma medida para resolução de problemas. Assim, não há apenas uma emancipação dos usuários, mas do próprio profissional, visto que seu papel "pode parar na descoberta e articulação da questão - [em que] identificar e expressar o problema não perpetua necessariamente o papel do design (...)"'46, como sugere o pesquisador Carl Di Salvo (2009, p. 60).

No momento em que designers se libertam da responsabilidade de chegar a um resultado concreto em projetos colaborativos, o cerne do trabalho passa a ser o processo e assim, o caminho passa a ser mais rico em termos de aprendizados, experiências e reflexões - especialmente no que se refere à autocrítica. Em razão disso, este trabalho focou inteiramente no processo, enquanto os resultados foram apenas um dos aspectos de reflexão acerca das experiências colaborativas. Ferrara (2002, passim) coloca que o "designer é o criador da percepção dos novos processos relacionais entre as várias linguagens que estão presentes no cotidiano", e sem seu resgate reflexivo, o desenho "se submete à tecnologia dos materiais e dos procedimentos que lhe são inerentes e prescritivos ou à esterilidade da competência técnica (...)", passando "a ser seu único parâmetro, seu único valor".

Para tanto, a prática projetual orientada prioritariamente na figura do usuário (ser humano) ou no resultado do espaço construído acabam por desconectar-se da situação em que se vive e seus entraves cotidianos. Desta forma, acreditou-se necessário reconhecer durante o processo a existência de questões específicas e situacionais, que englobam a complexidade do contexto e toda a rede de atores, humana e não humana. Reforçando esta ideia, as designers Janzer e Weinstein (2014) sugerem que as atuais práticas projetuais, focadas apenas no ser humano ou no ambiente construído, devem migrar para uma orientação associada à situação em que se vive, de modo que o design priorize o pertencimento da comunidade sobre o processo e a participação inclusiva, na qual a voz da comunidade é levada em consideração a todo momento.

46. No original: "Problem definition, as commonly conceived, implies the identification of a matter that can and should be addressed by design. However, (...) the role of the designer may stop at the discovery and articulation of the issue - identifying and expressing the issue does not necessarily perpetuate the role of design and the designer". 
Sanders e Stappers (2008) tocam neste ponto ao fazer uma retrospectiva acerca da abordagem de design centrado no usuário, iniciada nos anos 1970 e pulverizada nos anos 1990, considerada a mais útil no desenvolvimento de produtos para consumidores. Contudo, os autores ${ }^{47}$ reconhecem que atualmente a abordagem não pode abordar a escala de complexidade dos desafios que enfrentamos hoje:

Já não estamos simplesmente projetando produtos para usuários. Estamos projetando para as experiências futuras de pessoas, comunidades e culturas que agora estão conectadas e informadas de maneiras inimagináveis (...). Estamos passando do design de categorias de 'produtos' para projetar o propósito das pessoas. $4^{48}$

Ao projetar o propósito das pessoas, profissionais correm o risco de tomar para si toda a responsabilidade do processo, algo comumente visto e ainda recente nas reflexões revisadas em estudos de design. Em razão disso, valeu-se também de uma postura responsiva no design, que ao invés de colocar toda responsabilidade nas mãos do profissional como mediador, o integra ao projeto como parte integrante, ator participante. Esta concepção, sugerida pelos pesquisadores Adam Thorpe e Lorraine Gamman (2011), evidencia que as decisões tomadas são uma resposta ao contexto, a partir da colaboração de vários atores, assim sustentando múltiplos agenciamentos. Deste modo, o design carrega uma abordagem fraternalista em oposição à paternalista, reconhecendo que o profissional contribuirá de acordo com o contexto e as suas habilidades, e assumirá um agenciamento e responsabilidade similares ao de outros atores no processo.

No encontro dessas diversas camadas que compõe a postura crítica buscada neste trabalho, delineada a partir das reflexões apresentadas, concluo este tópico por meio do caminho que venho desenhando junto com as designers Ana Julia Almeida e Viviane Nicoletti, que acredita em uma prática de design que é relacional. A ideia de relacional nasceu a partir de estudos interdisciplinares, a fim de repensar os moldes da prática projetual tradicionais, na tentativa de humanizá-la e flexibilizá-la.

47. Ibid., p. 10.

48. No original: "We are no longer simply designing products for users. We are designing for the futures experiences of people, communities and cultures who now are connected and informed in ways that were unimaginable (...). We are moving from the design of categories of 'products' to designing for people's purposes". 
Tal abordagem relacional foi abordada na cultura com a atuação do antropólogo Roy Wagner (2010) que questiona a objetividade absoluta aplicada a grupos culturais em pesquisas de campo, uma vez que seus aspectos subjetivos variam de acordo com sua estrutura e suas especificidades. Para o autor ${ }^{49}$, cada cultura é uma manifestação específica equivalente a qualquer outra, podendo ser entendida por meio da "relatividade cultural" ${ }^{\circ}$. Neste sentido, o autor propõe que antropólogos adotem uma objetividade relativa, ao invés de absoluta, ao olhar para uma cultura estudada, visto que "a compreensão de uma outra cultura envolve a relação entre duas variedades do fenômeno humano; ela visa a criação de uma relação intelectual entre elas, uma compreensão que inclua ambas" ${ }^{\prime 1}$.

A troca entre antropólogos e seus campos de estudo pode ser trazida ao campo do design em seu viés de atuação e proposição com diferentes grupos sociais. A ênfase dada à objetividade absoluta no design funcionalista é aqui contestada segundo a noção de “objetividade relativa", já que esta "pode ser alcançada descobrindo quais são (...) as maneiras pelas quais nossa cultura nos permite compreender uma outra e as limitações que isso impõe a tal compreensão"52.

Na cultura popular da favela, vale-se da inventividade e criatividade local a fim de solucionar problemas. Em razão disso, o aspecto relacional em situações de encontro e interações com a Redes da Maré, apresentou-se como um caminho para a troca de aprendizados. Podemos pensar, portanto, em uma ideia de "design relacional" "53, que apoia-se na conciliação e reconhecimento do outro, para então, possibilitar experimentações coletivas, levando em conta a alteridade no processo. Assim como coloca

49. Wagner, op cit., p. 40.

50. Segundo Wagner (2010, p. 40) "uma vez que toda cultura pode ser entendida como uma manifestação específica ou um caso do fenômeno humano, e uma vez que jamais se descobriu um método infalível para "classificar" culturas diferentes e ordená-las em seus tipos naturais, presumimos que cada cultura, como tal, é equivalente a qualquer outra. Essa pressuposição é denominada "relatividade cultural".

51. Ibid., p. 40.

52. Ibid., p. 39.

53. Esta ideia foi proposta durante discussões do grupo de estudos, formado pela pesquisadora, a mestranda Viviane Nicoletti e a doutoranda Ana Julia Melo, durante leituras dos autores Roy Wagner, Marcel Mauss, Tim Ingold, Jacques Ranciére, Bruno Latour e outros. 
Wagner ${ }^{54}$ “a ideia de 'relação' é importante aqui, pois é mais apropriada à conciliação de duas entidades ou pontos de vista equivalentes do que noções como 'análise' ou 'exame', com suas pretensões de objetividade absoluta".

Deste modo, esta construção apoia-se em uma prática plural e situacional que está imersa em nossa "capacidade de apreensão dos rituais cotidianos daquele com quem se trabalha junto; na habilidade em promover emancipação intelectual, por meio do reconhecimento do lugar de fala e na igualdade de conhecimentos e diferentes sistemas de valores; nos modos de cooperação e aprendizado mútuo; e nas trocas contínuas que visam seu equilíbrio através da alteridade e reciprocidade"55.

Estas reflexões teóricas me auxiliaram na construção da pesquisa, principalmente no que se refere adotar um fazer em design que se permite e se deixa levar pelas circunstâncias, desafios e potencialidades do contexto que se trabalha. A seguir desbravo a postura que reconheci necessária para os movimentos atuais no design, explorando sua agilidade e raciocínio.

\subsection{Uma postura ativista no design}

À medida que esta prática relacional é buscada, os meios de atuação de designers vão sendo transformados naturalmente, de modo que outras formas de fazer sejam possíveis. Todavia, esta reorientação faz com que designers adotem uma postura nem sempre intrínseca ao seu trabalho: o ativismo. Diferente dos atores da Redes da Maré, que há anos desempenham papéis de resistência no território, designers não são formados para exercerem uma postura ativista. Mas, de uma forma geral, o que é agir como um ativista?

Em seu artigo 'Defining Design as Activism' - em português 'Definindo o Design como Ativismo' - a arquiteta Ann Thorpe (2011) faz um apanhado sobre a noção de ativismo e, na sequência, apresenta uma série de tipos de ativismos possíveis no design que envolvem múltiplas frentes de ação. Assim, a autora coloca que o "ativismo envolve a

54. Wagner, op cit., p. 40.

55. Trecho extraído de artigo submetido à Revista Arcos da ESDI/UERJ com autoria de Almeida, Montuori e Nicoletti. 
ação que faz reivindicação de mudança em nome de um grupo injustificado, excluído ou negligenciado - [que] é conduzido pela identificação de uma irregularidade ou problema que precisa ser alterado"56. De acordo com o pesquisador Tim Jordan (2002) o ativismo pode ser descrito como um compromisso moral, já que busca promover uma visão para uma sociedade melhor.

Por esta lógica, pensar o design através de lentes ativistas reposiciona a prática em um lugar de fala e ação que resiste às estruturas dominantes e procura meios viáveis de atuação que vão além dos funcionais, racionalistas ou solucionador de problemas. No caso deste trabalho, reconheci a minha postura ativista ao me auto convidar no âmbito da Redes da Maré, a fim de aprender e possivelmente colaborar com os parceiros da pesquisa Geisa Lino e Douglas Lopes, evitando imposições ou a introjeção de uma prática de design indesejada e totalizante.

Neste caminho, reconheci ao longo do processo a urgente necessidade de democratizar o design e as suas atividades como uma busca por abertura do campo, a fim de trazê-lo publicamente. Isto ocorreu em vista das inúmeras vezes em que percebi a prática projetual associada à resolução de problemas imediatos, ao embelezamento de coisas e a outros aspectos que menciono no terceiro capítulo ao falar do processo. Em contato com não-designers, notei o quanto a atividade projetual é desconhecida e desligada de um caráter político e social e que cabe a nós, pesquisadores, profissionais e estudantes, lutar por este reconhecimento em uma dimensão social ampla, não apenas para elites, grupos acadêmicos e espaços privilegiados, mas em um alcance maior que é baseado na vida cotidiana.

No caso da Redes da Maré, suas atividades são colocadas a público a todo momento. Sua ampla articulação social, cultural, política e principalmente digital permite que um público maior possa interagir com a sua atuação no território, quase como um convite frequente para pessoas de dentro e de fora. Um exemplo foi a realização da Marcha Contra Violência na Maré que aconteceu em 24 de maio de 2017 na Rua Principal, a qual tive oportunidade de acompanhar. A ampla participação de morado-

56. No original: "Activism involves taking action that makes claim for change on behalf of a wronged, excluded or neglected group - it is driven by the identification of a wrongdoing or problem that needs changing". 
res da Maré, atores da Redes da Maré, parceiros externos, jornalistas, artistas e outras figuras públicas e a extensiva divulgação na mídia tiveram como objetivo mostrar aos cidadãos cariocas e brasileiros o que efetivamente ocorre na Maré e que a urgência pela paz é de interesse coletivo. Embora estejamos falando de um contexto de emergência que não pode servir como base de comparação, perceber e aprender com esta postura me sinalizou empiricamente o vazio do campo em termos sociais e culturais e a necessidade de colocá-lo a público como meio de transformação social e urbana.

A ideia de trazer o design a público segue o sentido posto por Hannah Arendt (2007, p. 59) que sugere "que tudo que vem a público pode ser visto e ouvido por todos e tem a maior divulgação possível", já que "para nós, a aparência (...) constitui a realidade". O entendimento de público possui diversas interpretações, especialmente no que se refere a espaço público e esfera pública, no entanto, adoto o viés de público com a intenção de atentar-me para demandas em contextos reais, isto é, com foco no fazer projetual e não relacionado ao espaço estático ${ }^{57}$. Desta forma, o questionamento de que designers brasileiros poderiam pensar e co-projetar a cidade partindo da escala e da percepção humana - contribuindo por sua vez no desenho urbano - foi ampliado. Ao evidenciar a necessidade de democratização pública do design (Di Salvo, 2012), procurei formas alternativas de trabalho que fossem processuais, experimentais, reflexivas e atentas.

Apesar da imensidão de pesquisas envolvendo os temas design e cidade, por meios gráficos, fotográficos, técnicos, ilustrativos, analíticos e críticos, o vazio da profissão em relação a decisões políticas, econômicas, sociais e culturais no espaço da cidade ainda é presente. No Brasil, a democratização do design vem sendo discutida há décadas no que toca a busca por um design pautado em referências da cultura popular, caso das trajetórias profissionais e acadêmicas de Aloisio Magalhães e Lina Bo Bardi5 ${ }^{8}$.

57. O arquiteto pesquisador Eugenio Queiroga aborda em tese de doutorado um panorama sobre o entendimento de conceitos como esfera pública, esfera privada, espaço público e espaço privado e promove a discussão sobre público no que tange o sentido espacial do conceito, por meio de autores como Hannah Arendt e Jürgen Habermas. Cf. Queiroga, 2012.

58. A pesquisadora Zoy Anastassakis afirma que "Em Lina, assim como em Aloisio, pensar arquitetura e design também implicava em um forte envolvimento com as questões relacionadas ao patrimônio cultural, e do que poderia se chamar de "cultura popular"' (Anastassakis, 2012). 
Magalhães, com a sua forte atuação no Centro Nacional de Referência Cultural, lutava por um design com raízes brasileiras e bases industriais no âmbito da ditadura militar. Já Bo Bardi abriu mão de atuar em frentes modernistas para compreender as bases de artesanato popular no país, provando sua resistência especialmente quando lutou para desenvolver uma escola de design na Bahia e foi impedida pelo governo militar em que Magalhães lidou durante a sua atuação (Anastassakis, 2014).

Outros grupos, como a Associação Brasileira de Desenhistas Industriais (ABDI) e a Associação Profissional dos Desenhistas Industriais de Nível Superior do Rio de Janeiro (APDINS-RJ), também marcaram a história do design na luta pelo seu reconhecimento e legitimação. Ambos lutaram por um currículo completo e buscaram a regulamentação da profissão através de décadas ${ }^{59}$ entre impasses e disputas políticas.

Na arquitetura ${ }^{60}$, a postura ativista pode ser revisitada a partir dos trabalhos de Sérgio Ferro, Flávio Império e Rodrigo Lefebvre, nomes do 'Grupo Arquitetura Nova', que repensavam a prática isolada do arquiteto para uma que fosse mais coletiva, especialmente no canteiro de obras. Além desses, os trabalhos de Nabil Bonduki, Raquel Rolnik e Ermínia Maricato debruçaram-se desde a década de 1980 sobre o planejamento urbano por meio da concepção de uma geografia social urbana baseada em uma construção espacial coletiva. A postura de resistência é também evidenciada através da atuação de assessorias técnicas na construção de habitações de interesse social, caso dos grupos Usina e Peabiru.

Análogo às assessorias, outro exemplo é o trabalho do arquiteto e antropólogo Carlos Nelson Ferreira dos Santos durante o projeto de urbanização de favela em Brás de Pina, no Rio de Janeiro. O pesquisador Sérgio Abrahão (2008, p. 112), ao se debruçar sobre o trabalho de Santos, afirma que o arquiteto só poderia gerar "uma crítica específica da sociedade urbana se trabalhasse como agente consciente, metendo-se dentro dela, (...) para que algumas de suas expressões dominadas e reprimidas viessem à tona". Nesta direção, no seu contato com associações de moradores de favelas,

59. Cf. Braga, 2011.

6o. As referências a seguir podem ser acompanhadas em profundidade a partir da tese de doutorado de Marcos Rosa (2015). 
Santos ${ }^{61}$ buscou aprender "através da observação de suas práticas e do registro direto de seus discursos qual era sua realidade e oferecer-lhes em troca contribuições possíveis dentro de seus campos específicos de conhecimento".

No design internacional há diversos casos em que a disrupção no projeto pode ser reconhecida. Um exemplo é o projeto de colher de leite em pó desenvolvido por Gui Bonsiepe, que por meio de sua atuação na Organização Internacional do Trabalho no Chile, na década de 1960, auxiliou famílias na medição de leite diária necessária para crianças, sem que faltasse ou houvesse consumo excessivo (Mollenhauer in Miettinen, 2007). A disrupção em um único objeto permitiu que toda a cadeia alimentar infantil, baseada no leite fornecido pelo Estado, fosse transformada e melhor distribuída ${ }^{62}$. Este caso apresenta um tipo de ativismo no qual a disrupção ocorre por meio de um objeto que conseguiu promover uma prática de consumo sustentável e equilibrada.

Na arquitetura internacional, como coloca o pesquisador Guy Julier (2013, p. 223), os anos 1970 foram marcados pela ideia de 'arquitetura comunitária', "em que os usuários finais de planejamento e construção teriam um papel ativo na especificação da forma, configurando a co-criação e o design participativo"63. Um exemplo é a forma de trabalho do arquiteto Walter Segal no Reino Unido em meados de 1979. O arquiteto buscou de forma anárquica uma série de princípios inovadores de construção para que moradores de Lewisham, no sudeste de Londres, pudessem construir suas próprias casas no modelo de habitação britânico da época de acordo com o seu próprio gosto (Harper, 2015). Em um curta-metragem produzido pelo Architectural Foundation (2015), moradores da época expressam a relação de pertencimento e comunidade gerados a partir do formato de trabalho colaborativo promovido por Segal, ainda presente nos dias atuais. Um de seus colaboradores, Jon Broome coloca que Segal conseguiu "reduzir o design e a arquitetura à sua essência de um modo que possibilitou que as pessoas pudessem construir por conta própria"64.

61. Abrahão, 2008, loc. cit.

62. Ibid., p. 32-39.

63. No original: "wherein end-users of planning and building would have an active role in specifying form, itself configuring co-creation and participatory design".

64. No original: "reducing design and architecture to its essentials in a way that enabled people to build for themselves". Dizeres extraídos do curta-metragem "Walter's Way. The Anarchist Housing 
É interessante notar que todos esses exemplos carregam uma postura disruptiva na sua atuação, visando uma transformação de base que não gera simplesmente soluções inovadoras para problemas ${ }^{65}$, mas que impactam a prática projetual e o envolvimento social em longo prazo ao manter todos os atores ativos mesmo após a conclusão do projeto ou legitimando a prática profissional. Estas características são vitais ao que Thorpe (2011, p. 6, tradução nossa) descreve como "design ativismo", um movimento que "clama por mudanças, por meio do uso de métodos não convencionais, especialmente a disrupção de práticas regularmente reproduzidas, sistemas e estruturas de poder institucionalizado ou dominante". Uma vez que não há uma tradução elaborada ou oficializada, para esta pesquisa compreende-se o movimento como uma prática ativista por meio do design, a fim de alcançar meios disruptivos que propiciam outros caminhos de atuação e colaboração.

Debatido por diversos autores, o conceito é relativamente recente - pós anos 2000 - e vem sido discutido amplamente nos âmbitos do design e da arquitetura ${ }^{66}$. Para Julier (2013, p. 216), o movimento emergiu a fim de contestar a cultura de design comercial dominante, que apoia e promove o neoliberalismo, com o intuito de elucidar práticas com modelos alternativos.

Entre diversas abordagens de design ativismo investigadas, aquela abordada pelos designers escandinavos Lenskjold, Halse e Olander (2015) destacou-se por conta de seu alinhamento com a pesquisa. Para os autores, o design ativismo se apoia no conceito de 'devir menor' dos autores Deleuze e Guattari, que buscam evitar que interesses dominantes sobressaiam. Assim, atores de diferentes estratos sociais podem participar e

Estate". Disponível em: < http://www.architecturefoundation.org.uk/programme/2015/walter\%E2\%80\%99s-way-the-anarchist-housing-estate>. Acesso em: 10 Jan. 2018.

65. Nas palavras de Thorpe (2011, p. 1, tradução nossa). “Embora o 'bom' design geralmente trabalhe para provocar mudanças, em suas formas dominantes, o bom design (útil, rentável, bonito, significativo) geralmente não constitui ativismo em nome de grupos excluídos ou negligenciados. Em vez disso, constitui melhorias gerais para o cotidiano que são mais frequentemente adquiridas através do consumo privado, acessadas de acordo com a capacidade de pagamento do consumidor, quer o consumidor seja um indivíduo, empresa ou outra entidade".

66. Alguns autores são referência nesta temática, tais como Bryan Bell e Katie Wakeford (2008), Daniel Barber (2005), Alastair Fuad-Luke (2009), Thomas Markussen (2013), Guy Julier (2011), Tal Ulv Lenskjold (et. al., 2015), entre outros. 
discutir sobre o presente e possíveis futuros em relação ao tema debatido. Para tanto, este formato de design ativismo pode ocorrer por meio de princípios táticos ${ }^{67}$ do codesign, em que a experimentação é utilizada para trabalhar a especulação de desejos e cenários futuros ${ }^{68}$.

Embora o âmbito dinamarquês seja pautado em parâmetros sociais de menor desigualdade, pude notar práticas similares à sugerida pelos autores em situações brasileiras contemporâneas. Entre essas, destaco a atuação ativista de estudantes, docentes e funcionários da ESDI/UERJ que vêm juntos trabalhando e buscando caminhos alternativos para manter a escola viva mesmo com as drásticas condições impostas pelo Governo do Estado do Rio de Janeiro (Anastassalkis, 2018), como a falta de pagamentos e infraestrutura para a universidade. Destaco também a disciplina da FAU-USP 'Design para Sustentabilidade', na qual as professoras Dra. Maria Cecilia Loschiavo dos Santos e Dra. Tatiana Sakurai estabeleceram uma parceria com uma cooperativa de catadores da cidade de São Paulo, que lutam pela sua resiliência e reconhecimento. Esta troca é disruptiva, especialmente no âmbito acadêmico, visto que as docentes convidam catadores para participar das bancas de avaliação dos alunos e estes, por sua vez, participam do processo projetual ao longo do semestre (Santos; Sakurai, 2017).

Adicionalmente, cito o projeto realizado na Vila do Rosário, localizada na região metropolitana do Rio de Janeiro, pelos pesquisadores Marcelo e Andrea Júdice junto a moradores e a associação de moradores local que, por meio de ferramentas de codesign, buscaram solucionar a distribuição de informação acerca da tuberculose epidêmica (Neto; Castello-Branco in Miettinen, 2007, p. 32-53). Destaco também a parceria realizada pelo LaDA/ESDI/UERJ e o SEBRAE no Morro dos Prazeres, que colocou estudantes da escola para atuar junto com moradores por meio de processos envolvendo DA e dispositivos que estimulavam o diálogo (Anastassakis; Szaniecki in Smith et al., p.121-138), travado a partir de um certo momento, em vista dos interesses comerciais do SEBRAE, que ultrapassavam o processo de DA.

\footnotetext{
67. Tático pode ser compreendido aqui de acordo com a abordagem de Michel De Certeau (2014), que reconhece as táticas como ações/atitudes/formas de fazer que subvertem as estruturas sociais, opostas as estratégias, definidas por instituições de poder ou autoridade.
}

68. Lenskjold, op cit., p.71. 
Um ponto interessante que reúne cada um desses casos e expressa suas fraquezas e resistências em comparação ao contexto escandinavo está na dificuldade relacionada à interação com as estruturas de poder das instituições trabalhadas. Algumas criam entraves, caso do Governo do Estado e o SEBRAE ${ }^{69}$, ao não fornecerem infraestrutura, recursos e suporte para a realização de ações entre o âmbito acadêmico e o público. Outras sofrem entraves de instâncias superiores e são prejudicadas atrapalhando o desenvolvimento do processo colaborativo, caso da cooperativa de catadores em São Paulo e a associação de moradores na Vila do Rosário, ao lidarem com poucos recursos e falta de legitimação do poder público.

Julier (2013) nos dá uma explicação pertinente para estas relações imbricadas, a partir de sua leitura sobre o impacto do neoliberalismo na sociedade e sua capacidade de manipulação e flexibilidade em diferentes contextos. $\mathrm{O}$ autor ${ }^{70}$ coloca que o termo neoliberalismo é relativamente recente, pautado na prática econômica do liberalismo clássico de 1920 e cunhado em meados dos anos 1970 quando ganhou força diante de crises econômicas. Assim, estrutura-se a partir da desregulação de mercados, privilegiando forças mercadológicas livres da intervenção estatal; da privatização de empresas públicas; de interesses financeiros em detrimento à comunitários, civis, sociais e ambientais; e da ênfase na competitividade e no individualismo, bem como práticas de empreendedorismo.

No caso dinamarquês é possível perceber como as relações promovidas no âmbito público são mais práticas e menos imbricadas em aspectos políticos neoliberais, enquanto em países como o Brasil, conforme apontado por Julier ${ }^{71}$, o neoliberalismo só ganha espaço, perpetuando uma cultura de design mercadológica. Enquanto o contexto escandinavo carrega um histórico de design participativo baseado nas instituições de trabalho, pensar práticas experimentais de design democráticas é um caminho mais curto em comparação ao contexto latino americano, ao passo que pesquisadores escandinavos já propõem práticas que vão além de experimentações de codesign em

69. É importante mencionar que estes entraves são de escalas muito diferentes, já que o Governo do Estado deixou milhares de professores e funcionários sem pagamentos por meses a fio, enquanto o SEBRAE apenas optou por uma frente de atuação determinante diversa ao LaDA/ESDI/UERJ.

70. Ibid., p. 217.

71. Julier, op. cit., p. 226-227. 
âmbito institucional, para o âmbito público. Pesquisadores do CODE (Binder et al., 2015, p. 153) colocam que

O Codesign hoje ultrapassa o local de trabalho, as relações industriais e o quadro institucional para a 'democracia no trabalho' e se engaja com diversos públicos emergentes como ator em 'experimentos de design democrático' e deve encontrar uma maneira de se conectar com os marginalizados por infraestruturas hegemônicas. ${ }^{72}$

Embora exista uma maior aproximação dos dinamarqueses ao âmbito público, estes também lidam com entraves dentro de seu próprio núcleo de interesses no design, que nem sempre sustentam tais abordagens em consonância com a determinação governamental. Um exemplo é o fim do mestrado em codesign no CODE, visto que o interesse no curso era majoritariamente de estudantes estrangeiros, o que fez com que o governo impedisse a continuação do curso na universidade.

Portanto, compreende-se que realizar práticas experimentais democráticas é ainda um grande desafio no âmbito público que estamos inseridos. Ao reclamar a distância existente entre o público, o institucional e o cívico, é preciso pensar em atuações de design que promovam reflexão e mudança de percepção dos tomadores de decisão sobre futuros possíveis, seja a partir de negociações, processos dialógicos e/ou princípios táticos.

Embora estas observações só ganhem forma efetivamente na narrativa de processos vivenciados na Maré, elas são importantes para situar o leitor sobre a postura que foi adotada na pesquisa e como foi necessário trabalhar as minhas expectativas enquanto designer com relação aos parceiros na Maré. Uma vez que a postura ativista no design foi aqui explicitada, abro uma saída para próximo o capítulo, no qual apresento o contexto da Maré, seu cotidiano e a Redes da Maré. O próximo capítulo situará efetivamente o local em que inseri a minha postura ativista como designer e será o primeiro passo para introduzir a narrativa sobre as vivências em campo.

72. No original: "Codesign today goes beyond the workplace, industrial relations and the institutional framework for 'democracy at work' and engages in and with diverse emerging publics as an actor in 'democratic design experiments', and it must once again find a way to connect with those marginalised by hegemonic infrastructures". 


\section{CAPÍTULO 2}

\section{Contextualização: o Complexo da Maré e suas lideranças comunitárias}

\subsection{Um breve histórico do Complexo da Maré}

O Complexo da Maré, pano de fundo da Redes da Maré, teve seu desenvolvimento nas margens da Baía de Guanabara ao final da década $1930^{73}$ e é composto hoje por dezessete comunidades (figura 2), que foram oficializadas como bairros em $1994^{74}$. Estas são: Morro do Timbau (1940), Baixa do Sapateiro (1947), Conjunto Marcílio Dias ou "Kelson" (1948), Parque Maré (1953), Parque Roquete Pinto (1955), Parque Rubens Vaz (1961), Parque União (1961), Nova Holanda (1962), Praia de Ramos (1962), Conjunto Esperança (1982), Vila do João (1982), Vila do Pinheiro (1989), Conjunto Pinheiro (1989), Conjunto Bento Ribeiro Dantas ou “Fogo Cruzado" (1992), Nova Maré (1996) e Salsa e Merengue (2000). O termo favela, aqui usado, é o mesmo utilizado por moradores e pesquisadores do Complexo da Maré75.

Sua geografia é pouco acidentada, praticamente toda plana, com praias, mangues e portos que serviram de inspiração para o seu nome "Maré". Seu território é atual-

73. A pesquisadora Claudia Silva (2006, p. 29) relata em sua dissertação que o Morro Timbau foi a primeira comunidade formada e relata que "Dona Orozina, mulher negra, migrante e viúva, teria sido a primeira pessoa a construir um barraco na parte alta e vazia do morro, dando início ao processo de ocupação da Maré, na década de 1940". Cf. Silva, 2006.

74. Para mais informações acesse o Guia de Ruas da Maré, 2014. Disponível em: <http://redesdamare.org.br/blog/noticias/versao-atualizada-do-guia-de-ruas-da-mare/>. Acesso em: 20 Jul. 2017.

75. Ao longo da pesquisa alterno entre os termos favela e comunidade. O primeiro em função da prática comum de discurso na Maré, o segundo com a intenção de falar sobre uma comunidade de pessoas que compõe aquele espaço reduzido, que não se configura como bairro, já que a Maré já foi oficializada como bairro em 1994. 
mente concentrado entre duas grandes rodovias, a Avenida Brasil e a Via Expressa Presidente João Goulart - popularmente conhecida como Linha Vermelha - e é atravessado por uma terceira, a Avenida Governador Carlos Lacerda - popularmente conhecida como Linha Amarela (figura 3). Vizinho ao campus da Universidade Federal do Rio de Janeiro, localizada na Ilha do Fundão, e ao Aeroporto Internacional Antônio Carlos Jobim (Galeão), seu território carrega uma história de resistência e grande diversidade cultural com raízes do Nordeste brasileiro, Minas Gerais e também do próprio Rio de Janeiro, especialmente de remoções de antigas favelas como Esqueleto, Praia do Pinto, Morro da Formiga e outras (Redes da Maré, 2010).

Segundo Pasternak (2006, p. 186), "a favela no Brasil é um fenômeno, predominantemente, metropolitano (...)" e de acordo com o IBGE, em 2010, 88,2\% dos domicílios de aglomerados subnormais - termo formal utilizado ${ }^{76}$ - estão presentes em regiões metropolitanas, sendo que 19\% estão na região metropolitana do Rio de Janeiro. Neste ínterim, o Complexo da Maré, de acordo com o Guia de Ruas da Maré (2014)77, reúne uma população de mais de 130 mil pessoas, correspondentes a cerca de 40 mil domicílios, tomando o posto de "maior complexo carioca de favelas"78.

76. De acordo com os pesquisadores Jailson de Souza e Silva e Jorge Luiz Barbosa (in Barbosa; Dias, 2013) há uma homogeneização no modo como as favelas são representadas, que em suas palavras, trata-se de uma maneira banal, especialmente por conta de suas definições associadas apenas as suas carências e ausências. Para os autores (Ibid., p. 32) "A definição do IBGE, aglomerado subnormal, busca caracterizar diferentes tipos de territórios, tais como favelas, invasões, grotas, baixadas, comunidades, vilas, ressacas, mocambos, palafitas, entre outros" baseadas no Centro do Distrito Federal de 1948, totalmente associado a formas de ocupação densas, desordenadas e generalizadoras. Apenas em 2010, o Ministério das Cidades passou a definir as favelas como assentamentos precários e informais. Para os autores (Ibid., p. 33) "essa precariedade caracteriza-se por vários aspectos: pela irregularidade fundiária e/ou urbanística; pela deficiência da infraestrutura; pela ocupação de áreas sujeitas a alagamentos, deslizamentos e outros tipos de risco; pelos altos níveis de densidade dos assentamentos e das edificações combinados à precariedade construtiva das unidades habitacionais; pelas enormes distâncias percorridas entre moradia e o trabalho associadas a sistemas de transportes insuficientes, caros e com alto nível de desconforto e insegurança; além da insuficiência dos serviços públicos em geral, principalmente os de saneamento, educação e saúde".

77. Guia de Ruas da Maré. Trata-se de uma publicação que reúne uma compilação de mapas do território da Maré, desenvolvido pela própria Redes da Maré, a partir de diversas pesquisas sobre a população local, incluindo censo, entrevistas, mapeamentos, escolha de nomes para ruas sem nome, entre outras ações que auxiliam no reconhecimento da região em relação ao resto da cidade do Rio de Janeiro. O primeiro volume foi desenvolvido em 2012 e o segundo foi lançado em 2014.

78. Jacques in Varella et al., op. cit., p. 20. 
Sua área extensa concentra uma imensa diversidade de construções, ruas e vielas, que expressam sua formação histórica no âmbito político, social e urbanístico. Suas comunidades mais antigas (Morro do Timbau, Baixa do Sapateiro e Parque Maré) sempre estiveram sob pressão do Estado, que ameaçava remover as habitações irregulares ali presentes ${ }^{79}$. A falta de liberdade de expressão e a centralização de todas as decisões relativas a problemas urbanos, sobretudo no período da ditadura militar, “(...) desproveu os cidadãos de meios e canais de participação e expressão", principalmente em comunidades e favelas, gerando então "a inexistência de um espaço público político" que anulava "qualquer possibilidade de representação dos contendores mais fracos" (Abrahão, 2008, p. 117).

Segundo a pesquisadora da arquitetura Paola Jacques (in Varella et al. 2002, p. 21), “o passado da Maré é repleto de instabilidades, de constante transformação e de inúmeras reconstruções". Na Baixa do Sapateiro, área de localização de um dos espaços utilizados pela Redes da Maré, a vida cotidiana era marcada pela precariedade. "Não havia o controle militar, mas existia a repressão da guarda municipal, que se aproveitava dessa precariedade das construções" ${ }^{\prime 80}$ para derrubá-las. Esta atitude repressiva se dava também por conta da criação do Serviço Especial de Recuperação de Favelas e Habitações Anti-Higiênicas (SERFHA), em 1956, que determinava uma ação higienista de remoção de favelas no âmbito municipal (Silva, 2006, p. 86-87).

Em contrapartida, diante de uma situação de vida sem recursos, a oportunidade de trabalho no Rio de Janeiro e graças a fatores como a auto-organização, autoconstrução e modos de apropriação da Maré, que milhares de retirantes sobreviveram no local desde a década de 1940. Jacques ${ }^{81}$, ao observar a distinção entre a escola moderna de arquitetura na UFRJ em relação as construções do Complexo da Maré, reconhece que:

os construtores das favelas possuem uma lógica e uma cultura espacial própria, completamente diferente da lógica da arquitetura convencional da cidade formal. Trata-se de outro processo, outra forma de construir as próprias habitações, de reagrupá-las e, assim, de ocupar e se apropriar do espaço urbano.

79. Ibid., p. 19-37.

80. Ibid., p. 32.

81. Ibid., p. 49 . 
Historicamente, o ativismo e as lideranças comunitárias nasceram e ganharam força entre os anos 1950 e 1960 com a presença de associações de moradores que lutavam contra as constantes remoções no local ${ }^{82}$. Em 1957, é fundada a Associação de Moradores da Baixa do Sapateiro que se forma para "lutar pela permanência da população" ${ }^{83}$ e é a partir deste momento que as frentes comunitárias de poder no território vão se fortalecendo e se estruturando. Segundo a pesquisadora Alba Zaluar (in Zaluar; Alvito, 2006, p. 211), ao final da década de 1970 e durante os anos 1980 se estabelece a democracia participativa em contraponto à representativa, tendo por objetivo "conseguir uma posição autônoma em face do Estado e dos partidos políticos, (...)ao mesmo tempo reforçando a manifestação da diferença e da cidadania ativa". A luta pela melhora de condições de vida e a busca por direitos sofreu vários embates e influências, incluindo a Igreja Católica que, segundo Zaluar ${ }^{84}$, segmentou a população e reduziu os compromissos com interesses públicos:
A oratória comunitária exigia que o tribuno sempre falasse para a comunidade ou da comunidade, ou seja, de grupos locais demarcados, apenas acrescentando uma visão geral dos pobres como aqueles que deveriam congregar-se para resolver seus problemas por si mesmos, enquanto esperavam a Justiça final na Terra, como aqueles que care- ciam de trabalho, moradia, saúde, educação, melhores salários e assim por diante, ou seja, serviços e políticas governamentais, a maioria deles em nível local.

Entretanto, a autonomia gerou uma grande força na luta por direitos, respaldando a resistência de moradores e sua resiliência no local, especialmente diante de fatores ambientais e geográficos, específicos daquele território, fato que consolidou o primeiro momento de engrandecimento populacional local até meados de 1980. Porém é na

\footnotetext{
82. As pesquisadoras Lilian Vaz (1994), Caroline Santos (2015) e Claudia Silva (2006) fazem levantamentos precisos da história de formação da Maré, suas políticas públicas, remoções, transformações urbanísticas, lutas sociais e ativismos. As pesquisadoras relatam em detalhes cada fato marcante que determinou modificações no território, como a força industrial que moveu a construção da Avenida Brasil, e a imensa quantidade de moradores que atuaram no processo de construção; o Projeto Rio e o programa Promorar (Programa de Erradicação da Sub-habitação) de habitação popular que consolidou forças para que a construção fosse executada até o fim, entre outras ações que impactaram diretamente o território. Cf. Santos, 2015; Vaz, 1994; Silva, 2006.

83. Ibid., p. 33.

84. Zaluar in Zaluar; Alvito, 2006, loc. cit.
} 
transição entre 1970 e 1980 que os medos e temores constantes acerca de remoções começam a diminuir com a implantação do Projeto Rio, datado de 1979 (Santos, 2015, p. 54; Redes da Maré, 2010). Tratava-se de um projeto do governo federal que previa a erradicação e urbanização das favelas cariocas, visando uma operação urbana na região que readequaria milhares de moradias a um projeto urbanístico de habitação popular. O projeto previa a remoção de moradias em áreas de risco, como as palafitas instaladas nas margens da Baía de Guanabara, a construção de conjuntos habitacionais pelo programa Promorar (Programa de Erradicação da Sub-habitação), o saneamento da orla da Baía de Guanabara, entre outros que transformariam o espaço.

Segundo a Redes da Maré (2010), em seu fórum "A Maré que queremos" ${ }^{55}$, o Projeto Rio representou a força das organizações locais e sua capacidade de resistência, que após diversos protestos conquistaram a conclusão das obras em meados dos 1990. Embora houvesse uma emblemática força participativa focada na promoção de mudanças sociais e espaciais que melhorassem e provessem reconhecimento ao território, o espaço já se estabelecia entre rituais de guerra e paz, como coloca a fundadora da Redes da Maré, Eliana Sousa Silva (2015, p. 75):

No início da década de 1980, a Maré era formada por apenas seis favelas. O tráfico de drogas tinha ainda pouca expressão, mas as quadrilhas já começavam a exercer o poder sobre os territórios locais. No caso das comunidades Parque Maré, Rubens Vaz e Nova Holanda, havia dois grupos disputando o controle do tráfico. A fronteira entre os grupos era um valão existente em Nova Holanda, que dividia a favela em duas partes, a cerca de 50 metros da casa onde residi por quase 20 anos e de onde pude assistir muitas situações profundamente violentas (...).

A violência se intensificou no território a partir dos anos 1980 e a postura política governamental não contribuiu para que o crime e as facções criminosas fossem eliminados, ao contrário, a forma de atuação combativa só ampliou as disputas locais, estabeleceu fronteiras simbólicas violentas e perpetuou o estereótipo negativo da

85. 'A Maré que queremos' é um fórum permanente que existe desde 2009 e reúne as associações de moradores e a ONG Redes de Desenvolvimento da Maré. 'Redes de Desenvolvimento da Maré. Fórum "A Maré que queremos", Rio de Janeiro, 2010. Disponível em: < http://www.redesdamare.org.br/wp-content/uploads/2011/07/Projeto-A-Mar\%C3\%Ag-que-Queremos.pdf>. Acesso em: 12 Dez. 2016. 
favela entre outros grupos sociais de diferentes áreas da cidade ${ }^{86}$. Este fato foi também observado pela arquiteta Ermínia Maricato (1996, p. 27) ao se debruçar sobre as condições de vida nas regiões periféricas paulistanas, que reconhece a existência de um "desconhecimento da cidade real pelas classes médias e dominantes da sociedade" restrito ao "seu confinamento a uma área de circulação em 'ilhas de primeiro mundo", as quais desfrutam da "concentração de infraestrutura e equipamentos urbanos aliados ao mau funcionamento dos transportes públicos", determinando assim "a ocupação densa da cidade hegemônica".

Na transição das décadas de 1980 e 1990, a liderança social ganhou outras faces com a formação de Organizações Não Governamentais (ONGs) e instituições que, por meio de projetos envolvendo educação, esporte, arte e cultura, proporcionaram outra forma de resistência local (Silva, 2006). Um exemplo, é o início da atuação da ONG CEASM (Centro de Estudos e Ações Solidárias da Maré), espaço de origem da Redes da Maré, que focava em educação e no desenvolvimento territorial. Nos anos 2000, a iniciativa foi responsável pelo Censo Maré, que mapeou e identificou populações que viviam na Maré e não eram representadas nas estatísticas do IBGE. Assim como o antigo CEASM, hoje, as organizações possuem papel determinante de negociação na favela, engajamento político e social, produção de conteúdo, cultura e diretrizes organizacionais ${ }^{87}$.

A partir dos anos 2010 as relações de intermédio entre iniciativas e o público se intensificaram. Embora houvesse promessas governamentais que se posicionavam contra a postura violenta, exemplo do discurso utilizado na ocupação das UPPs (Unidades de Polícia Pacificadora) ${ }^{88}$, estas práticas nunca foram modificadas e o espaço é ainda

86. Ibid., p. 75-88.

87. Para informações detalhadas sobre os acontecimentos sociais, culturais e políticos da Maré desde a sua origem (1937) até meados de 2006, recomendo o quadro sinótico pela pesquisadora Claudia Silva em sua monografia “Maré a Invenção de um Bairro", o qual ilustra a evolução das favelas cariocas no Rio de Janeiro. Cf. Silva, 2006, p. 184-196.

88. As UPP (Unidades de Polícia Pacificadora) foram implementadas no ano de 2008 no governo de Sérgio Cabral na maioria das favelas cariocas, como coloca Silva (2015, p. 194) em uma breve consideração sobre a sua ocupação na cidade e "o grande apelo popular e eleitoral da medida". Cf. Silva, 2015. No artigo 'As Unidades Policiais Pacificadoras e os novos desafios para as favelas cariocas', Jailson de Souza e Silva (2010) narra as estratégias de implementação das UPPs em favelas do Rio de Janeiro e suas consequências. Disponível em: < http://observatoriodefavelas.org.br/wp-content/ uploads/2013/06/Aspectos-humanos-das-favelas-cariocas.pdf>. Acesso em: 17 de Mai. 2017. 
marcado por fronteiras que se modificam constantemente de acordo com os atores lá estabelecidos: as frentes ativistas das organizações, as atividades comerciais, os eventos culturais e de lazer, os equipamentos públicos e, principalmente, os confrontos entre facções criminosas, a milícia ${ }^{89}$ e a polícia militar, que impedem que os moradores levem uma vida tranquila e de paz. O território hoje é dividido em três principais frentes de violência que ordenam as fronteiras no território: a organização criminosa do Comando Vermelho, o Terceiro Comando e a milícia.

Embora exista um amplo trabalho das iniciativas com o território, o desconhecimento desta atuação e o distanciamento dos demais grupos sociais em relação a esta região, promovido expressivamente por representações tradicionais, fazem com que a exclusão histórica deste território seja ainda hoje reafirmada. Podemos utilizar da noção de "região" abordada pelo antropólogo urbano Michel Agier (2011) a fim de compreender como a fragmentação sócio-espacial na metrópole coagiu para que o Complexo da Maré, ainda que imenso, fosse encaixado no eixo das "regiões morais" como não civilizada. O estigma da favela, que por anos generaliza seu espaço como ambiente violento e vadio contribuiu para a sua segregação com a 'cidade formal', demarcando a região como marginal. Seu processo identitário formou-se entre as barreiras urbanas colocadas e pressionadas pelo Estado, que por décadas impuseram um processo de modernização funcional e sem qualquer reconhecimento sobre a alteridade do local, como coloca Agier ${ }^{90}$ :

A transformação dos espaços urbanos em fronteiras identitárias, mesmo em sua forma mais completa, a do bairro étnico, é sempre fundada sobre olhares cruzados que põe em jogo diferenças de gostos, de estilos de vida e de comportamentos. O conjunto desses critérios resulta de uma configuração global de valores morais à escala da cidade.

Eliana Sousa Silva (2015, p. 84), após anos de observação e dedicação ao espaço da Maré, afirma que "é um equívoco considerar que a favela seja um espaço dominado pela irracionalidade, pelo barbarismo e pela violência caótica; com efeito, há regras de

89. Para Jailson de Souza e Silva (2010), pesquisador e diretor do Observatório de Favelas, as milícias "são grupos dirigidos por integrantes das forças de segurança - policiais militares, civis, bombeiros militares e agentes penitenciários. Seus integrantes passaram a ser visibilizados especialmente a partir de 2007, quando começaram a ser reprimidos pelo, então, novo governo estadual".

9o. Id., p. 71. 
relações sociais estabelecidas e reconhecidas pelos moradores". A ideia de comunidade nas favelas, incluindo no Complexo da Maré, possui sentido diferente das demais áreas da cidade, seja devido a laços de permanência, a organização social ou a rituais cotidianos de pertencimento. É valioso notar que o espaço, ainda que degradado, é um local de troca, coletividade e muita criatividade. O espaço da Maré é um produto social e seus processos antagônicos de marginalização e vitalidade urbana por meio da ação coletiva são resultados da segregação e desigualdade na cidade do Rio de Janeiro. A socióloga Marilena Chauí (2001, p. 13) aponta que a produção do espaço brasileiro se dá a partir da concepção, na qual

A sociedade brasileira é marcada pelo predomínio do espaço privado sobre o espaço público e, tendo o centro na hierarquia familiar, é fortemente hierarquizada em todos os seus aspectos; nela as relações sociais e intersubjetivas são sempre realizadas como relação entre um superior, que manda, e um inferior que obedece. As diferenças e assimetrias são sempre transformadas em desigualdades que reforçam a relação mando-obediência. O outro jamais é reconhecido como sujeito, nem como sujeito de direitos, jamais é reconhecido como subjetividade nem como alteridade.

A relação de não reconhecimento da Maré como território e as desigualdades no acesso a serviços básicos, educação de base e segurança pública se mantém até os dias de hoje, inviabilizando que sua potencialidade cotidiana se enriqueça e beneficie com maior efeito aqueles que compõem os tecidos sociais e urbanos locais. Ao mesmo tempo, esta mesma potencialidade cotidiana permite que o espaço se transforme continuamente e se mantenha vivo de acordo com as necessidades diárias e as condições impostas ao território, que vive se reinventando. O geógrafo Milton Santos (2014, p. 138) ao tratar da ideia de território, afirma que este é afetado continuamente pela globalização ${ }^{91}$ e, portanto, reconhecê-lo representa entender o seu uso, seus objetos, suas ações, sinônimas ao espaço humano, o espaço habitado.

91. Para a pesquisadora Lucrécia Ferrara (2002, p. 68) "globalizar significa pensar globalmente, esse é o fenômeno cultural do mundo contemporâneo; fenômeno anti ideológico enquanto manipulação de uma classe ou poder", assim para a autora o mundo é globalizado a partir da sua imagem através do âmbito virtual, em que "o espaço já não mais se mede por distância ou proximidade, mas por uma contaminação cultural e informacional que gera um lugar virtual mais próximo do que qualquer vizinhança física. Essa contaminação produz uma comunidade de significados, valores e hábitos responsáveis por um padrão cultural, definidor do próprio sentido de globalização". 
Por esta lógica, o arquiteto Marcos Rosa (2015), em sua tese de doutorado, lança luz sobre a potencialidade de ação coletiva, envolvendo atores humanos e não humanos, proveniente do uso e da apropriação de infraestruturas utilitárias urbanas de larga escala ${ }^{92}$, evidenciando sua capacidade de articulação em rede no território. Neste âmbito, ao situar a favela como produto de uma construção social coletiva, o autor (2015, p. 169, tradução nossa) descreve que:

No Brasil, as favelas são geralmente áreas que foram quase inteiramente autoconstruídas, para receber infraestrutura básica depois; a maioria delas ainda falta serviços urbanos e instalações culturais e de lazer. Gostaríamos de chamar a atenção para a potencialidade dessas ações. Em primeiro lugar, parece relevante reconhecer a inteligência social e a capacidade da população local para melhorar as condições urbanas com base em suas necessidades, o que foi uma condição habilitada pelos quadros facilitadores de autoajuda criados nos anos 1980. Em segundo lugar, dentro da implementação da infraestrutura básica, há uma oportunidade de fornecer qualidade espacial, ou criar um quadro capaz de permitir que os residentes desenvolvem essas qualidades para o espaço comum, além do foco nas unidades habitacionais. Parece que a sobreposição desses esforços pode indicar outras formas suportando sua (auto) produção e gerenciamento de espaço coletivo de qualidade. A combinação desses elementos, historicamente reconhecidos como complementares, pode representar uma maneira de permitir a melhoria da qualidade espacial e o acesso às instalações culturais nesses ambientes. ${ }^{93}$

92. A partir da leitura da tese de Marcos Rosa (2015), interpreto as Infraestruturas Utilitárias Urbanas de Larga Escala (do inglês Large Scale Utilitarian Infrastruture, na sigla LSUI) como os produtos das metrópoles brasileiras baseadas no modelo urbanístico modernista implementado na segunda metade do século XX. Rosa (2015, p.14, tradução nossa), em sua tese de doutorado, refere-se as LSUI da cidade de São Paulo, por meio da seguinte passagem: "No século XX, (...) a infraestrutura foi providenciada em São Paulo como parte de uma agenda contínua que pretendia modernizar a cidade com o esforço de capacitar o crescimento da sua indústria e também da sua economia. Este processo geraria as Infraestruturas Utilitárias de Larga Escala - das águas, saneamento, iluminação até os transportes, educação, cultura e lazer - para a cidade que crescia em um ritmo sem precedentes. $\bigcirc$ projeto e implementação dessa estrutura no território impôs um plano tecnocrático para controlar e ordenar uma já existente aglomeração urbana. O resultado desta implementação expressa um entendimento do 'plano' como um instrumento utilizado para fomentar a prosperidade econômica, que seria obtida por uma bruta implementação da infraestrutura. No entanto, a implementação das LSUI é também um dos elementos chave para a leitura da evolução de uma geografia social desigual em São Paulo, caracterizando um território de exclusão fragmentado."

93. No original: "In Brazil, favelas are generally areas that have been almost entirely self-built, to receive basic infrastructure after- wards; most of them still lack urban services and cultural and 
Outro ponto relevante a ser tratado é a evolução das lideranças comunitárias ao longo do tempo diante das demandas locais e a consolidação cultural da Maré. No início, as lideranças eram baseadas principalmente nas associações de moradores, que com o tempo passaram a compartilhar suas responsabilidades com as organizações não governamentais. Até que em meados dos anos 2000 quando jovens expoentes da formação recebida pelas organizações passaram a desenvolver seus próprios coletivos, sem amarras institucionais e mais autônomos e independentes. Hoje, há uma série de coletivos que realizam atividades como registros audiovisuais acerca da memória da favela, caso do coletivo 'Amarévê'94, atividades esportivas como skate, caso do coletivo 'Slkate Maré’95, e práticas como a dança, música, e produção cultural, caso do 'Coletivo Maré’.

Este aspecto é retratado pela pesquisadora Cibele Rizek (in Jacques; Britto, 2015, p. 34), quando narra sobre suas incursões de pesquisa na periferia da Zona Leste de São Paulo e constata este mesmo movimento de emancipação e autonomia encontrado em coletivos e grupos artísticos. De acordo com a autora ${ }^{96}$.
Algumas das dimensões do desdobramento de programas e projetos que entrelaçaram a produção cultural com o trabalho social acabaram se constituindo em uma das saídas para o enfrentamento de um novo modo de conformação das práticas e da produção de arte e cultura: trata-se da constituição de coletivos de artistas - grupos de teatro, coletivos de dança, de artes plásticas etc. Esses grupos, assim como o

leisure facilities. We would like to call attention to the potentiality of these actions. First, it seems relevant to acknowledge the social intelligence and capacity of the local population to improve the urban conditions based on their needs, which was a condition empowered by the self-help enabling frames created in the nineteen eighties. Second, within the implementation of basic infrastructure, there is an opportunity to provide spatial quality, or to create a frame capable of enabling residents to develop those qualities for common space, apart from the focus in the housing units. It seems that the overlapping of these efforts may indicate other ways of supporting (self-) production and management of quality collective space. The combination of these elements, which have historically been acknowledged as complementary ones, might represent a way to allow for the improvement of spatial quality and access to culture facilities in these environments".

94. Amarévê. Página web do coletivo. Disponível em: < https://www.facebook.com/amarevecomplexo/>. Acesso em: 10 Dez. 2017.

95. Coletivo Skate Maré. Página web do coletivo. Disponível em: <https://www.facebook.com/ Coletivo-skate-mar\%C3\%A9-565906210277027/>. Acesso em: 10 Dez. 2017.

96. Ibid., p. 34 
número de profissionais envolvidos com o trabalho artístico, estão em crescimento significativo no Brasil, desde a década de 1990.

Levando em consideração que esta potencialidade está imbricada nas relações sociais, na memória e nos fazeres cotidianos, apresento no próximo tópico o cotidiano da Maré, a fim de elucidar as suas dinâmicas e formas de apropriação espacial no dia-a-dia que caracterizam seu espaço como lugar praticado, como abordado pelo historiador Michel De Certeau (2014). Esta ideia proposta infere que a ação humana provocada no espaço o transforma e ainda que ele tenha sido parcialmente projetado, ganha novos significados, signos, usos e apropriações. Portanto, entender o espaço da Maré, pela ótica de De Certeau ${ }^{97}$, compreende entende-lo como lugar, que define-se a partir de uma ordem própria que distribui elementos nas suas relações de coexistência. É onde, efetivamente, impera a lei do 'próprio', em que há uma configuração instantânea de posições, indicando sua estabilidade, em que a "desorganização" é, na verdade, o seu próprio equilíbrio.

Esta percepção reconhece a favela como um espaço de reinvenção e resiliência, especialmente por conta de sua ampla capacidade de adaptação espacial em contraponto à sua condição histórica na metrópole. Esta visão se traduz nos textos dos pesquisadores de favelas e territórios periféricos Jorge Luiz Barbosa e Jailson de Souza e Silva (in Barbosa; Dias, 2013, p. 37) quando colocam que

Uma das maiores potências das favelas cariocas é a imensa capacidade de inovação e criatividade de seus moradores e de instituições locais. A necessidade de garantir o suprimento de serviços urbanos centrais, tais como energia, água, coleta de lixo, calçamento, correios, canais fechados de TV, gerou soluções de variadas ordens e com diversas possibilidades de leitura e graus de concordância. A importância de regulação das vendas imobiliárias, a demanda por instâncias de representação diante do Estado, em especial, e de oferta de serviços públicos mais abrangentes geraram, por sua vez, a criação de associações de moradores, organizações da sociedade civil com bandeiras temáticas e

\footnotetext{
97. Citação completa de Michel De Certeau (2014, p. 184) sobre a definição de lugar: "Um lugar é a ordem (seja qual for) segundo a qual se distribuem elementos nas relações de coexistência. Aí se acha portanto excluída a possibilidade, para duas coisas, de ocuparem o mesmo lugar. Aí impera a lei do 'próprio': os elementos considerados se acham uns ao lado dos outros, cada um situado num lugar 'próprio' e distinto que define. Um lugar é portanto uma configuração instantânea de posições. Implica uma indicação de estabilidade".
} 
de muitos grupos mobilizados pela arte e pela cultura. Logo, a principal característica das favelas é, justamente, essa capacidade dos seus moradores de inventarem soluções alternativas para problemas de várias ordens do cotidiano. Assim, não é exagero afirmar que a favela é a expressão material mais consistente de formas inovadoras, coletivas e solidárias das lutas populares pelo direito à cidade.

A seguir apresento os espaços e o cotidiano da Maré, por meio de uma contextualização de suas dinâmicas diárias, características, usos e atividades que fazem com que seu território se caracterize com os aspectos anteriormente mencionados.

\subsection{A Maré, seus espaços e seu cotidiano}

Na intenção de compreender a Maré como um lugar, faço uma breve contextualização de seu cotidiano, o uso de seus espaços e as atividades cotidianas. Tive a oportunidade de vivenciar de perto cada um desses elementos e compreender como o encontro entre a diversidade imensa de atores faz com que o seu espaço seja diferente daquele reconhecido como a 'cidade formal'. Com relação a minha experiência como pesquisadora em campo, apresento a minha perspectiva no próximo capítulo quando me debruço sobre o processo de vivências na Maré. Por agora, me atenho a descrever o espaço Maré, seu cotidiano e realidade.

O espaço da Maré é composto por diferentes tipos habitações, que vão de autoconstruções a conjuntos habitacionais, variando de acordo com cada comunidade. Um exemplo é a Nova Holanda (figura 4), em que sua área é totalmente ocupada e sua base de moradia é a autoconstrução. Neste espaço, o caráter de improvisação cotidiana é um traço comum: vasos de plantas que viram bancos, janelas que viram lojas e lanchonetes, grades que viram varais para roupas, entre outras formas de apropriação. Esta tem uma forte influência cultural no território e é marcada pela sua dinâmica agitada, em que muitas pessoas ficam nas ruas e há muitos comércios. Em casos como a Nova Holanda, a favela é às margens da a Avenida Brasil e quem passa de carro, ônibus ou a pé, consegue visualizá-la de fora.

Outro exemplo é a Nova Maré, que embora esteja entre as duas comunidades mais antigas (Morro do Timbau e a Baixa do Sapateiro), é recente no território, implan- 


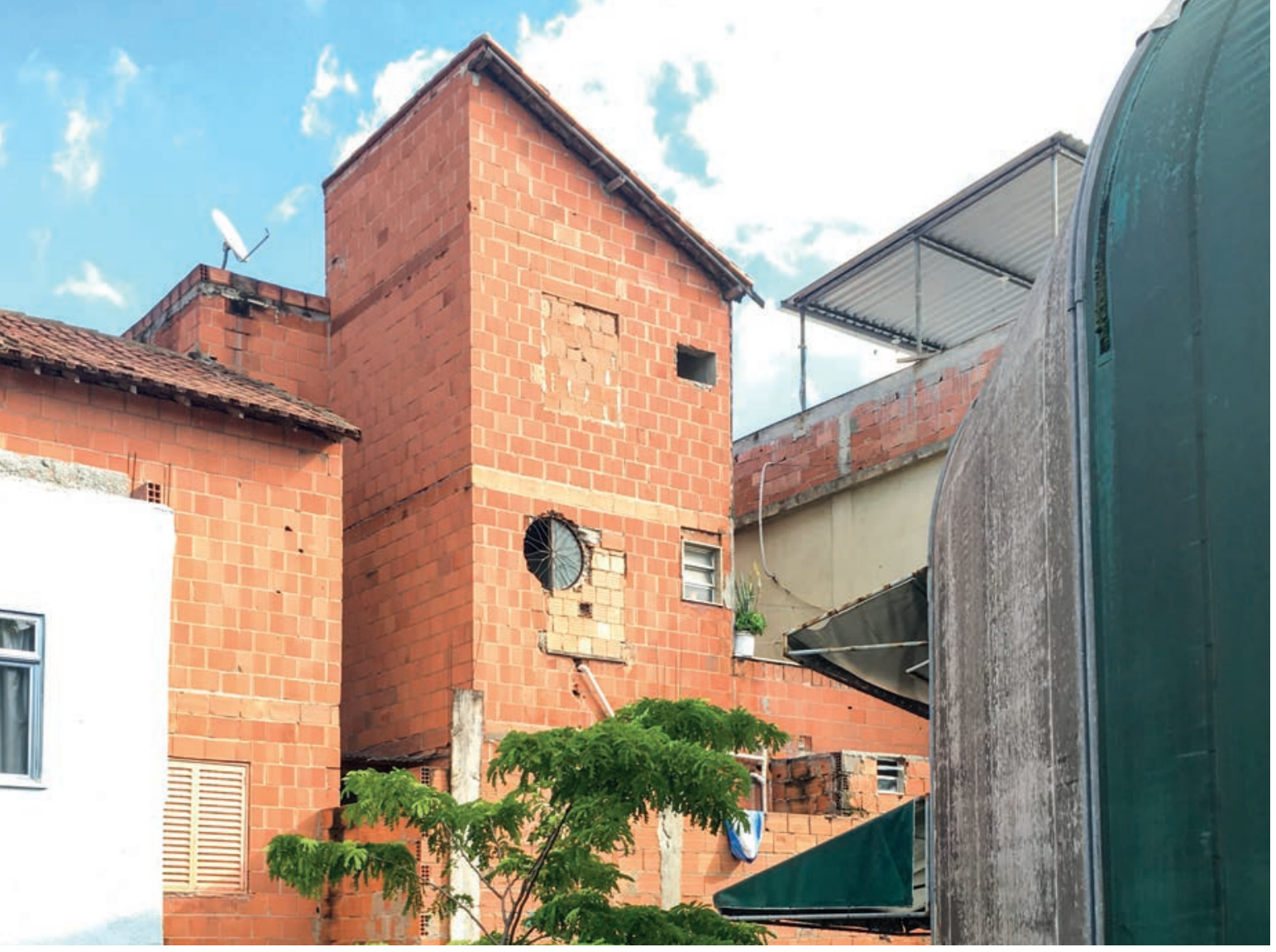

Figura 5: Nova Maré e a sua arquitetura. Fonte: fotógrafo Douglas Lopes, 2017.

nadas, aparentemente desprovidas de sentido", mas que neste desenho habitacional são bem vindas e acolhidas espacialmente ${ }^{98}$.

Como um todo, a Maré possui vários elementos comuns que compõem o seu ambiente construído e o caracterizam de forma particular, tais como: comércios variados, dentre eles restaurantes, lanchonetes, lojas, feiras (figura 7), açougues, mercearias, bares e barraquinhas de comida; igrejas, predominantemente evangélicas, encontradas em casas, garagens, galpões e muitos outros locais; ferros-velhos, em que é possível encontrar rodas, parafusos, muitos tipos de materiais de construção e ferramentas; equipamentos culturais, como a lona cultural, museu, galpão de arte, dança, eventos e concertos; espaços públicos, como praças, quadras de futebol e vôlei; consultórios médicos particulares, que atendem moradores e trabalhadores; fábricas e indústrias, que vão de reciclagem à produção editorial; serviços de serralheria e marcenaria, especializados e 


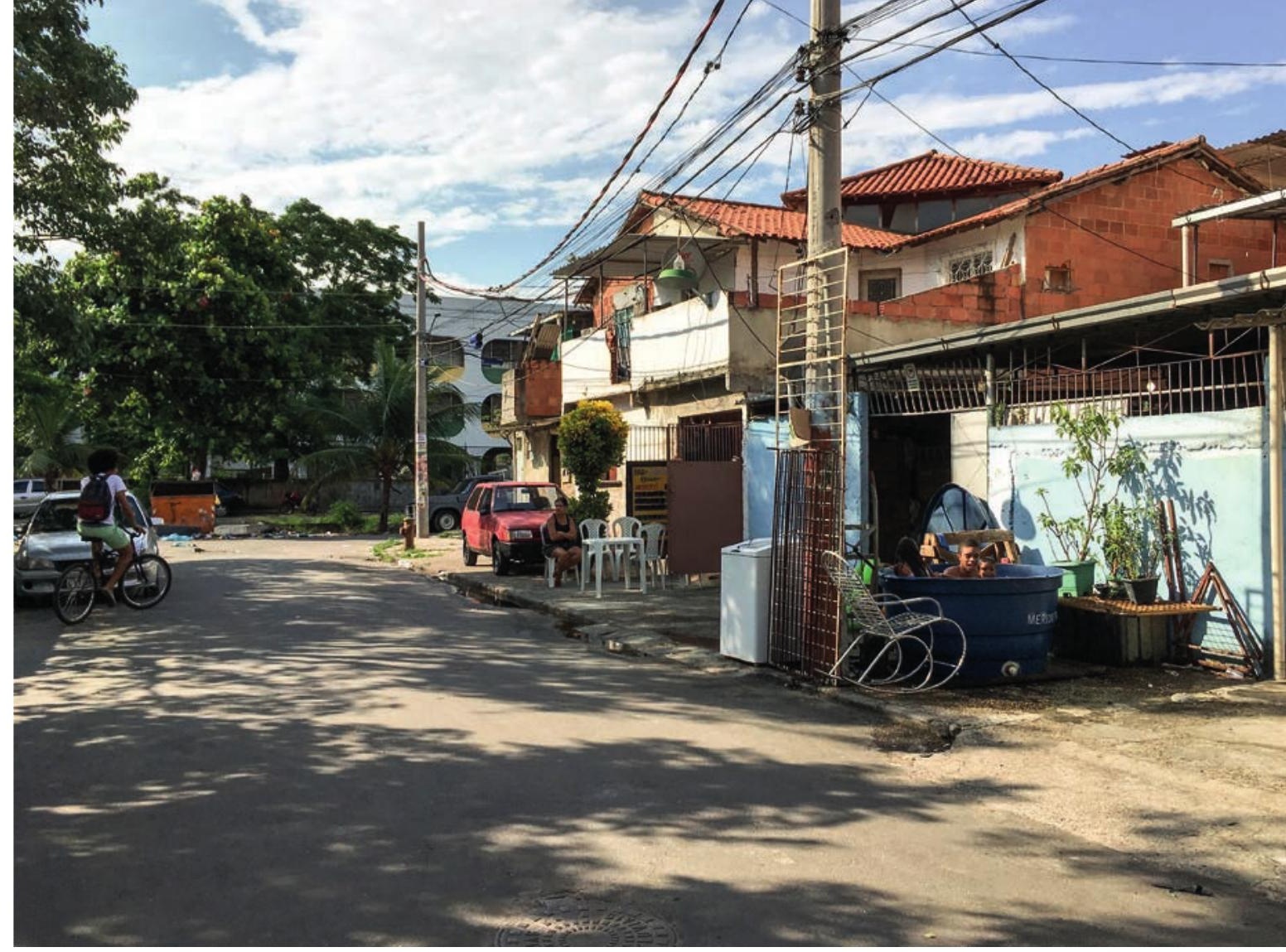

Figura 6: exemplos de usos e apropriações na Nova Maré, tais como a caixa d'água que vira piscina e a garagem que vira restaurante. Fonte: autora da pesquisa, 2017.

práticos para construções; ONGs, que atuam em pró da educação e dos direitos da população; e associações de moradores, que auxiliam na organização das comunidades.

Eliana Sousa Silva (2015, p. 52), ex-moradora e frequentadora da Maré a mais de trinta anos relata com nitidez o que é estar na Maré em um dia comum9:

No dia-a-dia da Maré, elementos fortes são percebidos imediatamente: o cheiro forte nas vielas em função do sistema de esgoto precário; a música permanente, principalmente funk ou forró; as ruas principais ocupadas por barracas, que vendem os mais diversos produtos; a grande variedade de lojas, na maior parte das vezes de médio e pequeno porte, destacando-se os muitos espaços de venda de bebidas alcoólicas; a grande frota de veículos, especialmente motos, bicicletas e vans, que disputam as ruas com uma multidão de pessoas de todas as idades, principalmente crianças, adolescentes e mulheres - presenças permanentes nas ruas, em todos os horários e dias, com destaque para

99. Recomendo fortemente a leitura do livro 'Testemunhos da Maré' de Eliana Sousa Silva (2015), especialmente entre as páginas 52 a 57, em que a autora dá uma descrição detalhada das atividades cotidianas locais e os grupos sociais. 
Embora a Maré esteja frequentemente viva e efervescente, é também um espaço em que as pessoas ficam alertas a tudo que ocorre e está para acontecer. Isso ocorre, pois o seu cotidiano é imprevisível. Todos os dias são uma incerteza para as pessoas que lá residem e frequentam, especialmente nos últimos anos em que o conflito foi constante. É inviável situar a Maré sem mencionar o conflito, pois um dia comum para o morador, muitas vezes, é um dia em que é impedido de sair e comprar seu pão na padaria, ou levar os filhos na escola, seja por conta de tiroteios, invasão policial ou toque de recolher. Esta situação urgente e calamitosa é constante e presente, e nas vias de controlar o que ocorre nesse espaço, atores do território procuram canais de comunicação que informam quando, onde e o que ocorre a cada instante no local. Esta capacidade de rápida transmissão da informação é um produto de sua resiliência espacial, na qual moradores se organizam e cuidam uns dos outros no dia-a-dia.

A Maré é um organismo vivo em constante transformação. Podemos associá-la à 'Cidade Cinética', explorada por Rahul Mehrotra (2008) em seus estudos sobre Mumbai na Índia. A Cidade Cinética é aquela não reconhecida pelo âmbito formal da arquitetura e percebida, em termos espaciais, por seus padrões de ocupação disformes, dinâmicas temporais, indeterminância e instabilidade. A Cidade Cinética está sempre em negociação com a Cidade Estática, isto é, a cidade formal planejada nos termos de Paola Jacques (2007), se movimentando e se modificando para sobreviver diante de suas condições. Nela encontramos "a sabedoria local no mundo contemporâneo sem medo do moderno, enquanto a Cidade Estática aspira apagar o local e a recodificá-lo em uma ordem escrita 'macro-moral'. Inspirado por princípios modernistas de design urbano, a Cidade Estática reorganiza periodicamente a Cidade Cinética em sua própria imagem ${ }^{100 " . ~ E ́ ~ i n t e r e s s a n t e ~ n o t a r ~ c o m o ~ a ~ M a r e ́ ~ f o i ~ c o n s t a n t e m e n t e ~ o b r i-~}$ gada a se ajustar aos planos urbanísticos formais e ainda assim conseguiu se reconfigurar socialmente, culturalmente e espacialmente para coexistir na cidade de acordo com suas próprias resistências diárias.

100. Mehrotra, op. cit., p. 214, tradução nossa. No original: "The Kinetic City carries local wisdom into the contemporary world without fear of the modern, while the Static city aspires to erase the local and recodify it in a written 'macro-moral' order. Inspired by modernist urban-design tenets, the Static City periodically remakes the Kinetic City in its own image". 
Além disso, para o indiano ${ }^{101}$, a "Cidade Cinética obriga a Cidade Estática a se reengajar nas condições atuais, dissolvendo seu projeto utópico para fabricar múltiplos diálogos com seu contexto". A Maré obriga o Rio de Janeiro a pensar no modelo de cidade que estamos vivendo e nos ajuda a imaginar outras formas de viver a cidade, de modo que esta seja mais integrada, viva e plural. Aproveito esta passagem para retomar uma das falas de Geisa Lino ${ }^{102}$, parceira na pesquisa e moradora da Maré desde seu nascimento: "A Maré não é um problema só para mim e para os seus moradores. A Maré faz parte da cidade do Rio de Janeiro, logo seus problemas são de todos os cidadãos. Se lá estamos sofrendo com tiros, este sofrimento e responsabilidade de mudança deveriam ser de todos os cidadãos da cidade, não apenas de quem reside lá..."

Levando em consideração o cotidiano da Maré e suas contradições, me debruço a seguir sobre a organização Redes da Maré e a sua atuação em rede no território, que há mais de dez anos vem impactando diretamente a qualidade de vida das pessoas. Além disso, traço um panorama em que revelo a organização da iniciativa e a autonomia de sua cultura, por meio de um esboço da estrutura organizacional, atores, espaços usados, projetos, parceiros e outros itens relevantes no seu entendimento.

\title{
2.3 A Redes de Desenvolvimento da Maré: a ação em rede no território
}

Em sua dissertação, Claudia Silva (2006, p. 147), ex-integrante do Centro de Estudos e Ações Solidárias da Maré (CEASM), relata:

\begin{abstract}
Essa organização não governamental foi fundada em 15 de agosto de 1997, por um grupo de moradores e ex-moradores da Maré que, tendo chegado à universidade e militando no movimento social, se reuniu para desenvolver um trabalho sistemático de intervenção na realidade local, a partir de projetos relacionados à educação e à cultura.
\end{abstract}

Esta passagem conta o início de uma semente plantada no Complexo da Maré, que hoje, mais de vinte anos depois, construiu raízes fortes e influentes no território. Como relatado, a CEASM nasceu a partir da união de moradores e ex-moradores que

101. Ibid., p. 216, tradução nossa.

102. Dizeres de Geisa Lino no evento Iniciativas Participativas em 13 de março de 2017 no Studio-X, Rio de Janeiro. 
juntos trabalharam extensivamente para trazer educação e cultura para a região. A organização iniciou a sua atuação efetivamente em 1998 a partir de um curso pré-vestibular que contava com duas turmas de setenta alunos cada, e no ano de 2002 ampliou suas atividades por meio de parcerias com a Fundação Leão XIII ${ }^{103}$ e a Associação de moradores da Nova Holanda ${ }^{104}$.

Em meados de 2001, nascia outra organização chamada Observatório de Favelas ${ }^{105}$. Faço menção a esta organização, por conta de sua troca contínua com a Redes da Maré até os dias de hoje e sua influência direta neste trabalho, como será mostrado no próximo capítulo. Parceira do CEASM, a organização atua como uma plataforma de pesquisa e formação focada nos estudos das metrópoles e favelas. Com o objetivo de formar pesquisadores locais de comunidades e ampliar o conhecimento qualificado sobre as favelas e fenômenos urbanos, a organização atua em frentes de ação em educação, políticas urbanas, comunicação, cultura e direitos humanos. Seu diretor, Jailson Souza e Silva, vem trabalhando neste processo desde a sua origem, abarcando o desenvolvimento em pesquisas envolvendo aspectos sociais, raciais, econômicos e culturais das favelas cariocas, que visam desestigmatizá-las ${ }^{106}$.

103. A Fundação Leão XIII surgiu em 1946 com a finalidade de oferecer suporte assistencialista em favelas cariocas, por meio da ação da igreja, com o propósito de evitar a expressão comunista nas favelas. Embora seu caráter político determinante, promovia implantações de serviços básicos como água, esgoto, luz e redes viárias, além de centros sociais, visando qualidade de vida para moradores de favelas. Segundo o pesquisador Marcelo Burgos (in Zaluar; Alvito, 2006, p. 29) "ao que tudo indica, a escala e o modelo do trabalho realizado pela Fundação não foram capazes de inibir uma articulação maior entre os moradores das favelas e outros segmentos da sociedade carioca." A Fundação atua até os dias de hoje e está vinculada Secretaria de Estado de Ação Social e Direitos Humanos do Estado do Rio de Janeiro (SEASDH). Disponível em: < http://www.leaoxiii.rj.gov.br/quem_somos. asp >. Acesso em: 10 Jan. 2018.

104. Ibid., p. 149

105. Observatório de Favelas. Página web sobre a sua história, Rio de Janeiro, 2018. Disponível em: <http://of.org.br/nossa-historia/>. Acesso em: 23 Jul. 2017.

106. Silva e Barbosa (in Barbosa; Dias, 2013, p. 33) colocam que "O Observatório de Favelas (...) tem buscado formular uma interpretação desses territórios populares que leve em conta sua potência, suas particularidades, suas demandas e complexidades. Negamos, assim, uma apreensão simplificada da pobreza, centrada em indicadores que afirmam apenas carências e limites nas condições dos moradores locais e dos territórios que construíram". 
Entre os trabalhos desenvolvidos, destacam-se os projetos Solos Culturais, o Guia Cultural de Favelas, Mídia e Favela, Cultura e Periferia, Imagens do Povo e muitos outros ${ }^{107}$, que promovem pesquisa e promoção de conhecimento não apenas em favelas e na Maré, mas em vários bairros da cidade. Estes trabalhos abordam temas culturais e típicos das regiões periféricas do Rio de Janeiro, suas potencialidades e formas de articulação por meio de ferramentas como fotografia, vídeo, mídia e comunicação (redes sociais), registros escritos, entrevistas, guias, entre outros materiais que envolvem conteúdos temáticos.

Em um caminho semelhante, a Redes de Desenvolvimento da Maré - nome completo da organização - se originou em 2007, a partir de um desdobramento do Curso Pré-Vestibular Comunitário da Maré realizado pelo CEASM. A iniciativa, classificada como Organização da Sociedade Civil - mesma categoria das Organizações Não Governamentais (ONGs) - atua com "a missão de pensar o espaço da Maré em uma perspectiva de longo prazo e em escala global", em que seu eixo conceitual se baseia no "Desenvolvimento Integrado do espaço local" (Nóbrega Junior et al., 2012, p. 7). Partindo desta premissa, a organização impacta o território através de cinco eixos de ação e uma variedade de projetos, espaços e cursos que englobam temáticas emergentes do território e oferecem atividades variadas para todas as idades.

Os cinco eixos de atuação são: Arte e Cultura; Desenvolvimento Territorial; Direito à Segurança Pública e Acesso à Justiça; Educação; Identidades, Memória e Comunicação. Já os projetos são: Projeto de Vínculos Solidários, Projeto Curso PréVestibular Comunitário, Projeto Censo Maré, Projeto Escola de cinema Olhares da Maré, Projeto Nenhum a Menos, Projeto Xô Dengue, Projeto Azulejaria, Projeto Maré de Sabores, Projeto Maré de Direitos, Projeto Maré sem Fronteiras, Projeto Mão na Lata, e Projeto Núcleo de Memória da Maré. Seus espaços são: Sede da Redes da Maré, Centro de Artes da Maré, Lona Cultural Herbert Vianna, Biblioteca Lima Barreto e Maria Clara Machado, Biblioteca Popular da Maré Jorge Amado e Casa das 
Mulheres. Os cursos que oferecem são: Pré-vestibular, Preparatório para o Ensino Médio, e Instaladores de Drywallio8.

Sua fundadora, Eliana Sousa Silva, foi moradora da Maré por mais de vinte anos e nunca rompeu os laços com o território. Doutora em Serviço Social, Sousa atua por melhores condições de vida na Maré e se posiciona na linha de frente na luta por direitos humanos e educação, sempre legitimando a produção de conhecimento e cultura do território. Junto a Sousa, a Redes da Maré possui uma gama de atores, reconhecidos como "tecedores", que atuam nos espaços, projetos e cursos e são em parte funcionários, em parte voluntários, tanto de dentro quanto de fora da Maré.

Pude perceber durante os períodos em que estive presente na Maré que a organização não leva este nome por acaso. A função articuladora da iniciativa é uma característica chave, visto que além de promover diversas pontes por todo o território, realiza parcerias de todos os tipos e em todos os cantos do Rio de Janeiro e arredores, envolvendo artistas, coletivos, ativistas, jornalistas, figuras públicas, pesquisadores, educadores, laboratórios de extensão universitária, empresas e fundações. Visto que há muitas ações e descrever cada uma delas seria um ato interminável, opto por apresentar apenas aquelas em que estive inserida durante o meu período de pesquisa de campo, descritas no próximo capítulo. Na página a seguir, apresento um esboço de sua estrutura em formato de fluxograma que esquematiza os eixos de atuação, os projetos, espaços, cursos, a distribuição de seus atores, as suas parcerias internas e externas ${ }^{109}$ (figura 8) e também uma linha do tempo (figura 9) que inicia em 2012 e engloba algumas atividades relevantes para a compreensão do contexto. É importante mencionar que muitos atores não estão presentes neste esquema, visto que há uma imensidade de pessoas atuando na organização, por isso apenas os responsáveis foram colocados.

Entender a Maré a partir da atuação da Redes da Maré requer a compreensão da noção de território como uma base na qual a imensa variedade de atores humanos e não humanos, isto é, pessoas, coisas e espaços, se comunicam, se relacionam e estabele-

108. Estas informações foram extraídas da página web oficial da Redes da Maré. Disponível em: <http://redesdamare.org.br/eixoseprojetos/>. Acesso em 18 Jan. 2018.

109. Todas as informações relacionadas a sua atuação podem ser vistas também na página oficial da organização. Disponível em: < http://redesdamare.org.br/>. Acesso em: 10 Jan. 2018. 
Diretoria

Alberto Aleixo de Souza

Andréia Martins

Edson Diniz

Eliana Sousa Silva

Helena Edir Vicente

\section{Eixos \& coordenadores}

- Eixo Educação

Gisele Martins

Eixo Arte e Cultura

Isabella Porto

Eixo Desenvolvimento Territorial

Maíra Gabriel Anhorn

- Eixo Direito à Segurança

Pública e acesso à justiça

Lidiane Malaquini

O Eixo Identidades, Memória

e Comunicação

Alberto Aleixo de Souza

\section{Histórico}

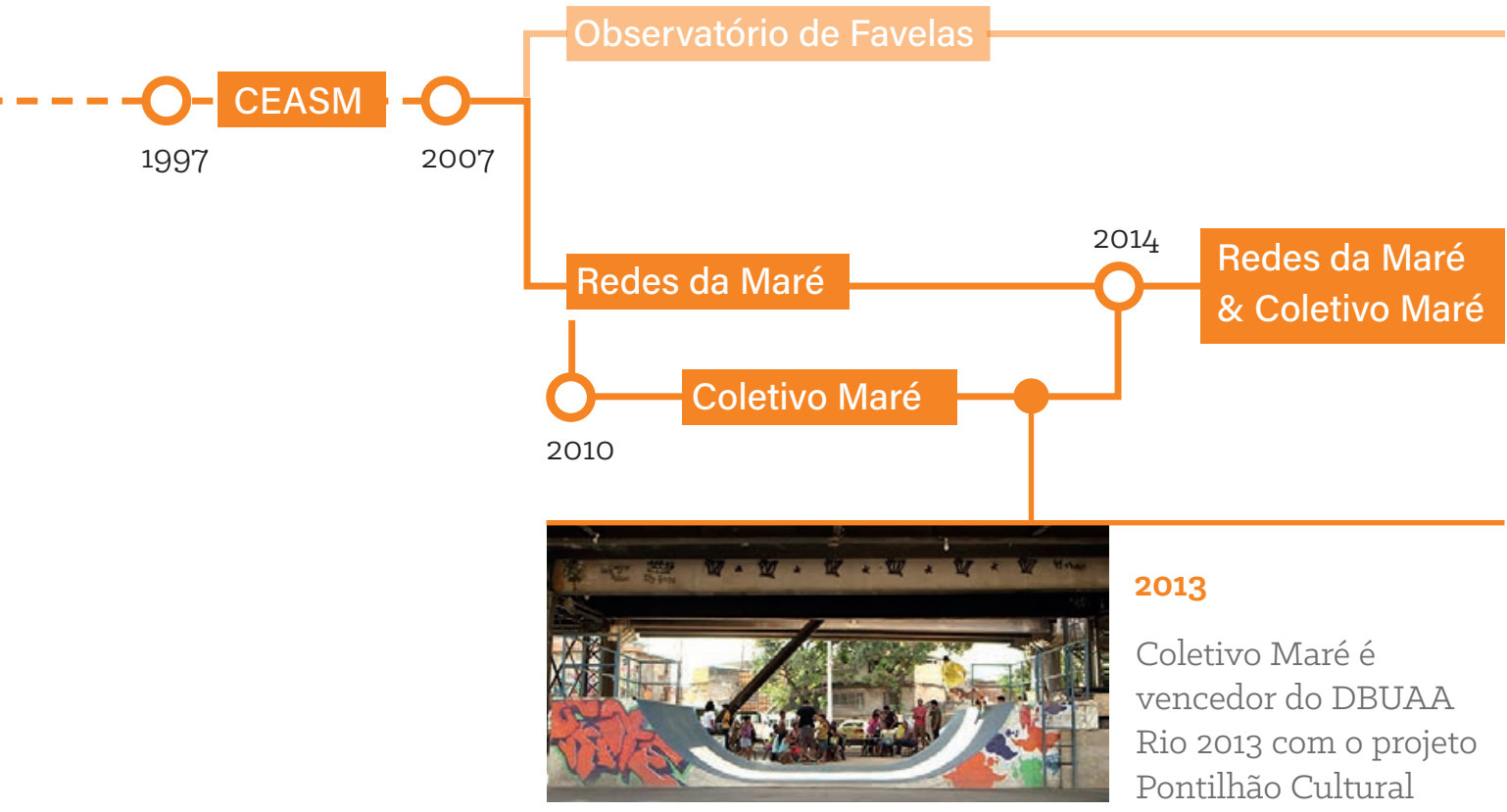


Projeto de Vínculos Solidários

Ana Claudia de Oliveira Britto

Projeto Curso Pré-Vestibular

Comunitário da Maré

Claudia Santos

Ernani Alcides Alexandre da Conceição

Projeto Censo Maré

Dálcio Marinho

Projeto Escola de Cinema

Olhares da Maré

Diego de Jesus Santos

Projeto Nenhum a Menos

Inês Cristina Di Mare Salles

Curso Preparatório para o Ensino Médio

Kelly Cristine Marques da Silva

Projeto Xô Dengue

Kelly Cristine Marques da Silva

Projeto Azulejaria

Laura Taves

Projeto Maré de Sabores

Mariana Aleixo de Oliveira

Projeto Maré sem Fronteiras

Suelen Brito

Projeto Mão na Lata

Tatiana Altberg
Projeto Núcleo de Memória da Maré

Tereza Cristina S. de Souza

Projeto Maré de Direitos

Patricia Ramalho Gonçalves

Produção de Conhecimento do

Eixo de Segurança Pública

Thais de Jesus Custodio

Incidência Política do

Eixo de Segurança Pública

Marina Motta

Mobilização do

Eixo de Segurança Pública

Shyrlei Rosendo

Curso de Instaladores de Drywall

Patricia Vianna

Bibliotecas Lima Barreto

e Maria Clara Machado

Luciene Vieira de Andrade

Lona Cultural Herbert Vianna

e Centro de Artes da Maré

Geisa da Silva Lino

Casa das Mulheres da Maré

Shirley da Luz Villela

\section{Parceiros}

Observatório de Favelas

Bela Maré

Muda Maré

Luta pela Paz

Data Labe

Cia Marginal

Cia de Dança Lia Rodrigues

Coletivo Ao Vento

Cicloativistas externos

Produtora Automatica

\section{Atores importantes não mencionados}

Douglas Lopes, Henrique Gomes, Julia Rossi e equipe Muda Maré, Rodrigo Maré, Marcos Diniz, Yuri Lobo, Daniel Remlik, Mariane Rodrigues, Carlos Marra, Luana Senna, Roberto França, Dayana Sabani, Renan Braga, Sarah Alves, Paulinho, Jonas Willame, Fagner França, Gilberto Vieira, Clara Sacco e Mariana Mello. 

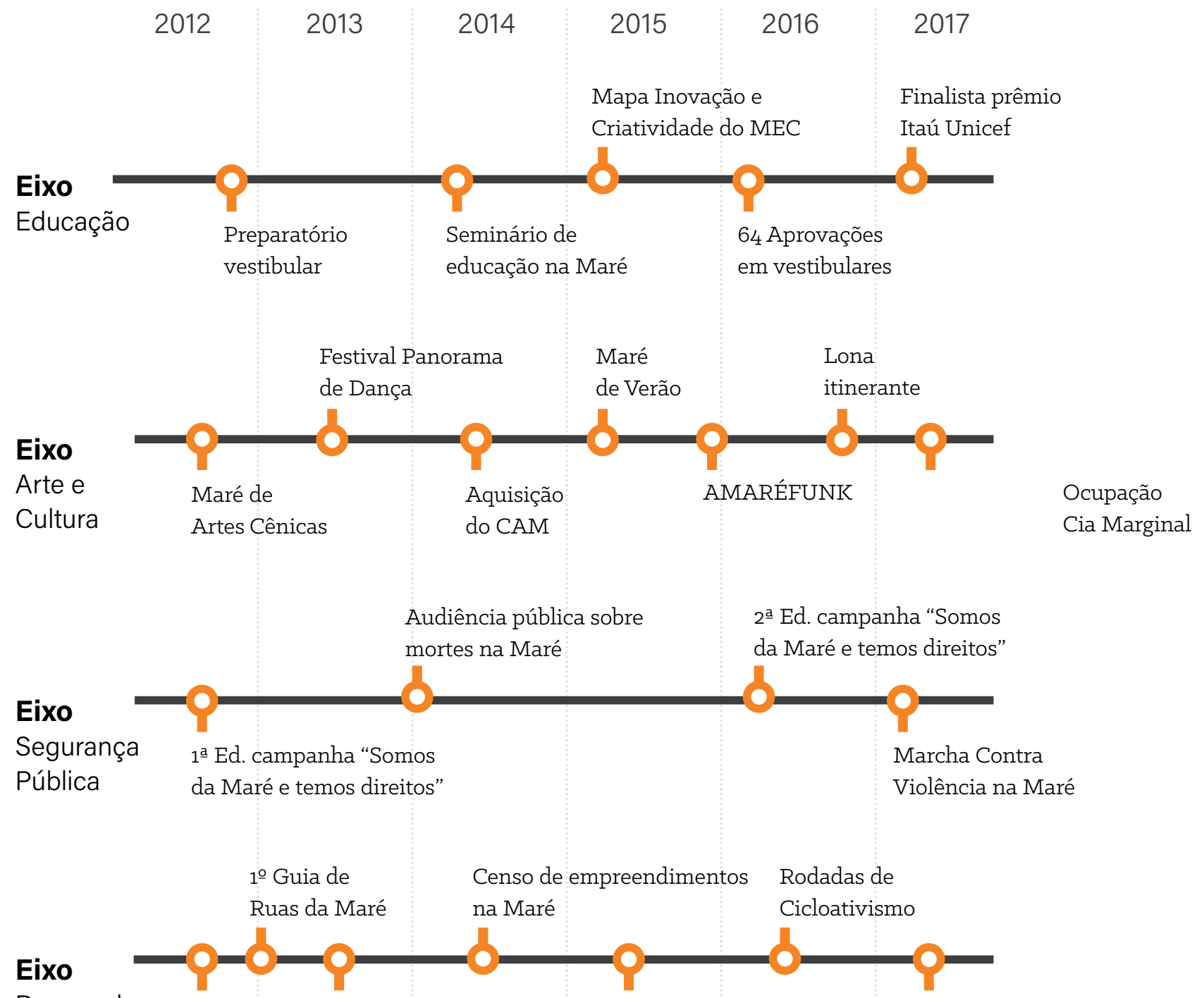

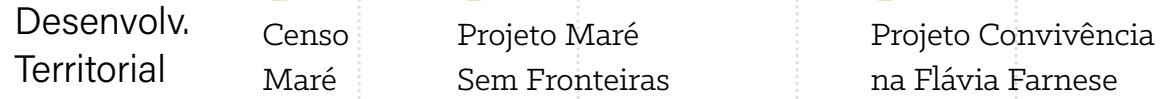

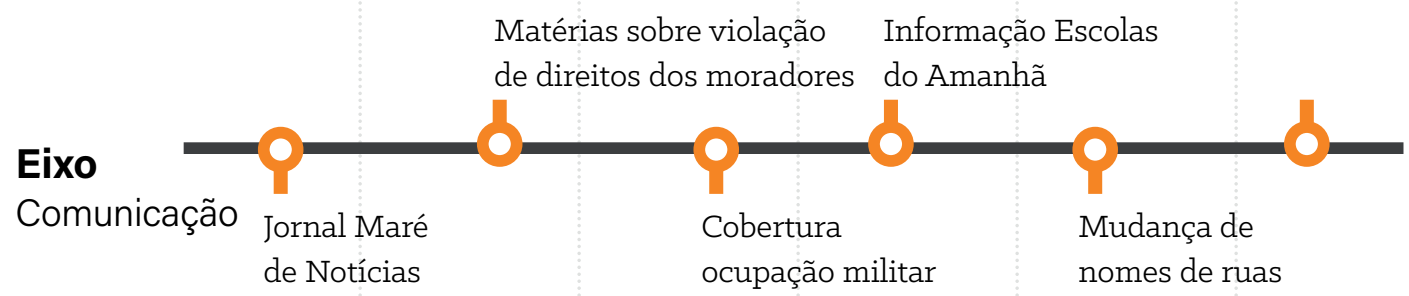

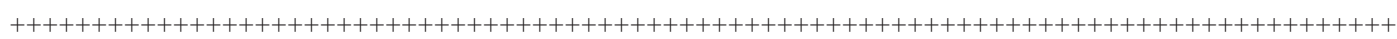
Figura 9: linha do tempo Redes da Maré com alguns de seus feitos desde 2012. Fonte: elaborado pela autora em colaboração com Geisa Lino, 2017. 
cem ordens hierárquica. Na concepção de Milton Santos (2014, p. 138-139), compreende-se o território como formas, que quando usadas são objetos e ações, significando o espaço humano e habitado, expressado como lugar, que é construído socialmente. Para o autor ${ }^{110}$, "o território, hoje, pode ser formado de lugares contíguos e de lugares em rede. São, todavia, os mesmos lugares, os mesmos pontos, mas contendo simultaneamente funcionalizações diferentes, quiçá divergentes ou opostas".

Por este raciocínio, o geógrafo nos apresenta duas leituras: uma a partir da dimensão local do espaço, que habitado ganha expressão como lugar; outra a partir do território, que quando conectado por meio de seus lugares, ganha expressão como rede, possuindo múltiplas funcionalidades, que são ubíquas e contínuas. Ao mesmo tempo, o autor sugere que a formação de redes na cidade é baseada em estruturas tecnocráticas e ordenadas de cima para baixo, no mesmo parâmetro elucidado por Rosa (2015) ao descrever as Infraestruturas Utilitárias de Larga Escala.

Assim, para Santos (2014), os espaços em que a rede não chega podem ser entendidos como os espaços banais, já que não são suportados por ela, visto que ela atende apenas estruturas de poder em que só alguns têm acesso. Ao mesmo tempo, para Rosa ${ }^{111}$, é nesses espaços banais, caso do Complexo da Maré, em que há oportunidade para o surgimento de pequenos pontos de ação coletiva, carregados de potencialidade criativa, que habitam e transformam os espaços. Ao pensar na rede como uma estratégia para o lugar, o arquiteto ${ }^{112}$ aproveita estas oportunidades para realizar uma leitura de potencialidades do local, que é reprogramado de espaço vazio para um local de contato, com sua própria identidade e capacidade de recodificação e mudança ao longo do tempo, capaz de receber novas entradas e reagir a elas. São nessas oportunidades que a Redes da Maré constrói a sua rede no território, evidenciando potencialidades locais e explorando-as com o intuito de qualificá-las, promovendo consequentemente engajamento e inclusão social.

110.Santos, 2014, loc. cit.

111. Ibid., p. 40.

112. Ibid., p. 41 
Partindo das ideias até aqui elaboradas, me debruço sobre um tópico particular na relação entre atores e atividades na Maré: os espaços utilizados. A Maré e seu território extenso, embora denso e muito ocupado, permitiu que vários espaços pudessem ser utilizados de formas diferentes, com apropriações diversas. É interessante notar que há uma variedade grande na caracterização desses espaços, visto que alguns são apropriados por meio de editais públicos e outros por direito de aquisição privada, alguns são utilizados permanentemente e outros apenas temporariamente, alguns são espaços livres e outros fechados.

Levando em consideração a diversidade de espaços utilizados é impossível reuni-los em categoria únicas como públicos e privados, ou livres e fechados. Por isso, escolho o termo 'espaço coletivo', a partir da leitura proposta por Rosa (2015, p. 160), que olha diretamente para o "conteúdo social do espaço, reconhecendo o ato de fazer espaço como processual e envolvendo vários agentes". Assim, o autor ${ }^{113}$ refere-se ao espaço coletivo como

(...) aquele resultante da articulação de processos coletivos e que desenvolveram uso coletivo, ainda que este possa ser organizado em uma área privada, ou na esfera infraestrutural. Esta noção refere-se fortemente as iniciativas (...), onde processos de inteligência coletiva clamam a transformação espacial, muitas vezes melhorando o território (da rede) a ser habitado. ${ }^{114}$

A escolha do termo 'espaço coletivo' ao invés de 'espaço público', evita discussões que colocam o 'espaço público' em oposição ao 'espaço privado'115. Deste modo, é possível direcionar o olhar para a construção coletiva desses espaços e entendê-los como espaços situacionais, em que as situações vividas na vida cotidiana caracterizam seus usos e especificações. A ideia de situação foi muito explorada a partir da Internacional Situacionista, vanguarda europeia que contou com nomes como Guy Debord, Henri

113. Ibid., p. 163, tradução nossa.

114. No original: "We would like to focus on the social content of space, recognizing the act of making space as processual and involving several agents. We will refer to collective space as the one resulting from the articulation of a collective process and which developed collective use, even though it might be organized in a private area, or in the infrastructure realm. That notion refers strongly to the initiatives that we will later showcase in our field work findings, where processes of collective intelligence claim the transformation of space, often improving the (network) territory to be inhabited". 
Lefebvre e Constant Nieuwenhuys, que entendia a vida cotidiana a partir de momentos, situações vivenciadas que rompiam com a alienação associada à aplicação modernista sobre os espaços e a vida urbana ${ }^{116}$. Nas palavras de Rosa ${ }^{117}$ "os momentos, construídos em situações eram considerados momentos de ruptura. Este não apenas critica as infraestruturas modernas, mas busca nelas por situações potenciais. O sistema e as redes se transformam em suportes para essas situações" ${ }^{\prime 18}$.

Essa descrição pode ser percebida, por exemplo, em espaços como o Pontilhão Cultural, área embaixo do viaduto - infraestrutura de larga escala - por onde passa a Linha Amarela na Maré. O espaço, antes utilizado para despejo de lixo e tráfico de drogas, foi transformado a partir da ação coletiva, por meio de atividades culturais como concertos, aulas de skate e encontros, promovendo a modificação em seus usos e apropriações.

Como um todo, a Redes faz uso de espaços permanentes e temporários, abertos e fechados, públicos e institucionais. Entre seus espaços principais permanentes estão o edifício sede da Redes da Maré e suas bibliotecas internas Lima Barreto e Maria Clara Machado (infantil), o Centro de Artes da Maré, a Lona Cultural Herbert Vianna, a Biblioteca Popular da Maré Jorge Amado, localizada no interior da Lona Cultural, e a Casa das Mulheres. Cada um desses espaços abriga projetos, cursos e atividades, que em sua grande maioria são abertas ao público gratuitamente.

Com relação aos espaços temporários, ainda que sejam poucos, a iniciativa conta com as praças da Nova Holanda e do Parque União, o Pontilhão Cultural e o Parque Ecológico da Maré. Estes são espaços usados para encontros esporádicos ou eventos e atividades fora dos espaços institucionais da organização. Vale ressaltar que a bicicleta é um meio muito utilizado entre membros da iniciativa e participantes, visto que a mobilidade é um caminho muito utilizado para engajamento social e o rompimento de fronteiras de conflito. Por meio da bicicleta, os espaços citados são continuamente

116. Este tópico é amplamente abordado por Vanessa Grossman (2006) que se debruça historicamente sobre a Internacional Situacionista. Cf. Grossman, 2006.

117. Rosa, op. cit., p. 113.

118. No original: "The moments, constructed in situations were to be considered moments of rupture. It does not only criticize the modern infrastructures, but seek in them for potential situations. The system and networks are to become the support for the situations". 
conectados, abraçando a identidade de cada comunidade envolvida. O mapa (figura 10) na próxima página apresenta a localização dos espaços e as suas particularidades.

\subsection{De Coletivo Maré para Redes da Maré: entre autonomia e organização}

Como mencionado no primeiro capítulo, iniciei a pesquisa partindo da atuação do Coletivo Maré, grupo organizado por Alberto Aleixo, atual diretor da Redes da Maré, e Geisa Lino, atual coordenadora do Centro de Artes da Maré e da Lona Cultural Herbert Vianna, ambos provenientes da Maré. Além deles, o grupo contava também com a colaboração de Douglas Lopes, fotógrafo e designer gráfico, nascido e residente no Morro do Timbau.

Os três viveram sob os braços da Redes da Maré desde quando esta era apenas CEASM. Aleixo, sobrinho de Eliana Sousa Silva, sempre participou das atividades e atuou em pró do território, enquanto Lino era do núcleo de dança na juventude, mas tomou gosto pela produção cultural e se enveredou por esse caminho. Em meados de 2010, os dois amigos se reuniram e resolveram iniciar um coletivo independente que realizaria produções culturais em espaços da Maré e assim, desenvolveram o projeto do Pontilhão Cultural.

Com poucos recursos e muito empenho, especialmente braçal, realizaram uma parceria com o Coletivo Skate Maré, convocaram ajudantes e se articularam com bandas e artistas a fim de ocupar este espaço deteriorado. Conjuntamente limparam o espaço, colocaram iluminação, construíram um palco e realizaram um evento que contou com a alta frequência de moradores e visitantes. Após o evento continuaram a utilizar o espaço para outras ações, incluindo atividades lúdicas para crianças, plantação de mudas, entre outros encontros.

Em agosto de 2013, conheci o grupo em uma visita com o Dr. Marcos Rosa na Maré, quando realizávamos pesquisas de campo em favelas cariocas no intuito de encontrar iniciativas que estavam transformando e qualificando os espaços da metrópole. Após conhecermos a atuação do Coletivo, os encorajamos a se inscreverem no prêmio, que seria julgado no segundo semestre de 2013. Desta forma, foram classificados em segundo lugar, recebendo parte dos cem mil dólares. 


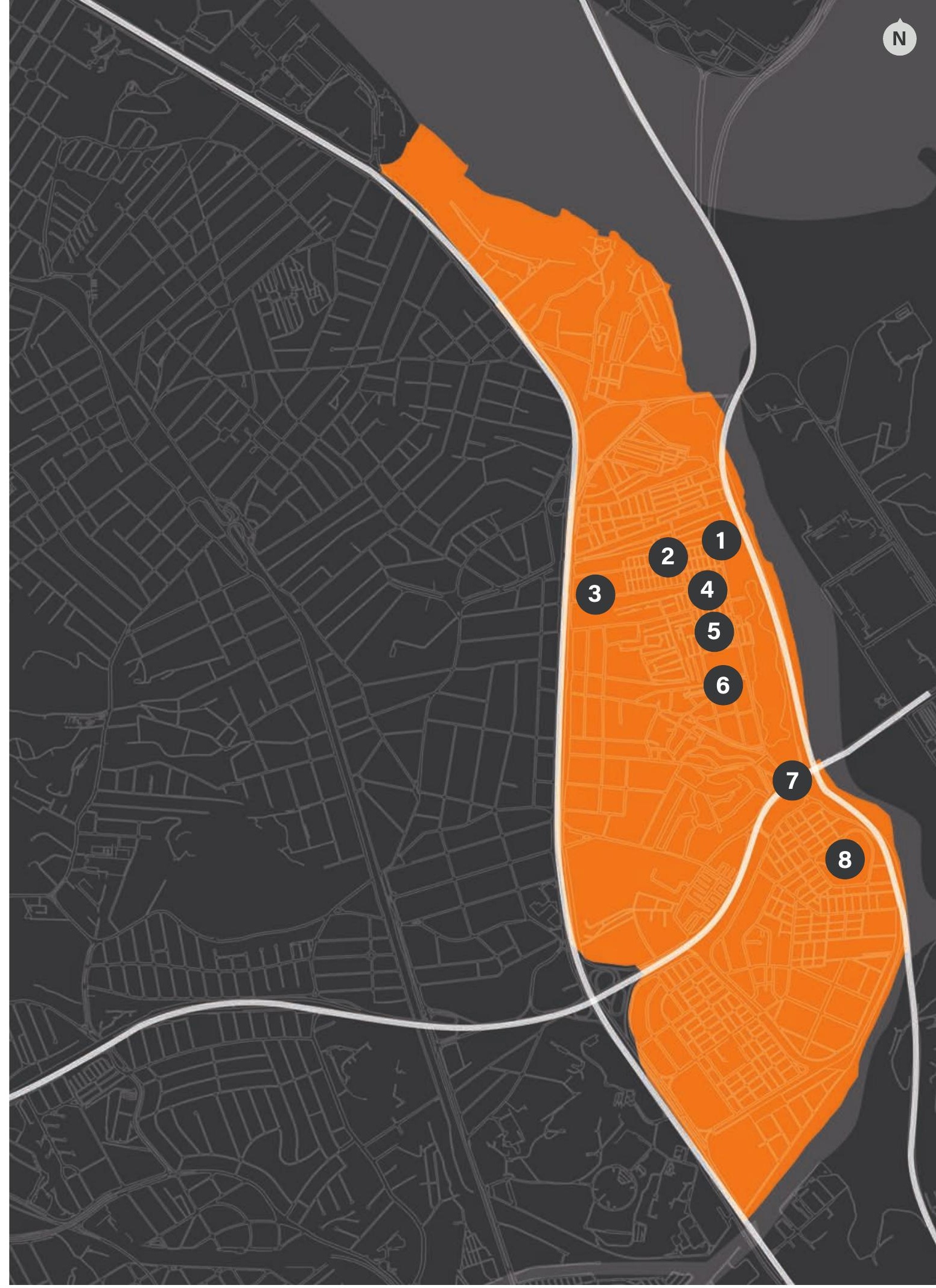

Figura 10: mapa da Maré, os espaços utilizados pela Redes da Maré e suas especificações (continua na próxima página). Fonte: elaborado pela autora, 2017. Foto 1 de Luiza Xavier; foto 2 de Elisângela Leite; fotos 3, 4 e 8 de Douglas Lopes; fotos 5, 6 e bibliotecas da autora; foto 7: DBUAA. 


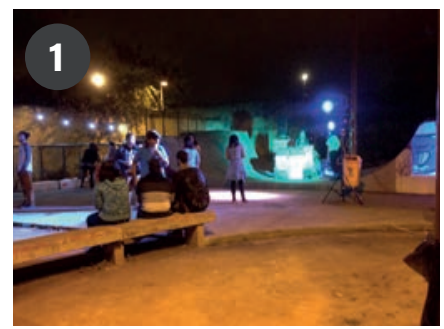

Praça do Parque União

Espaço aberto de uso

público e uso temporário.

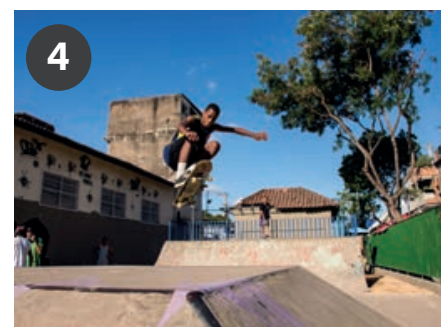

\section{Praça da Nova Holanda}

Espaço aberto de uso

público e uso temporário.

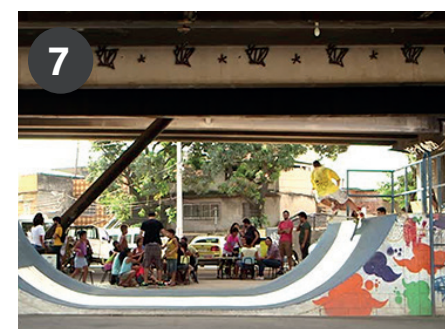

\section{Pontilhão Cultural}

Espaço aberto de uso público e uso temporário.

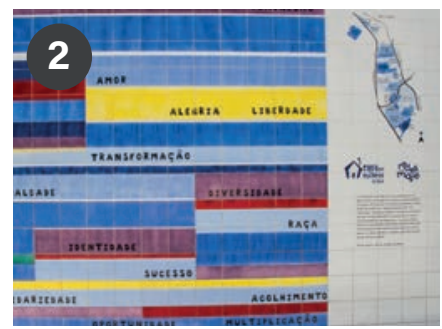

Casa das Mulheres Espaço fechado de uso privado e uso permanente.

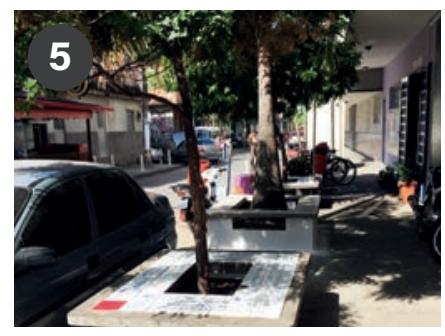

\section{Sede Redes da Maré}

Espaço fechado de uso privado e uso permanente.

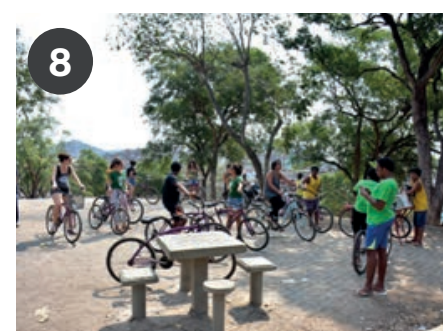

\section{Parque Ecológico}

Espaço aberto de uso público e uso temporário.

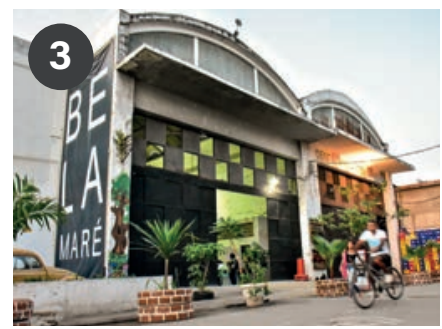

Centro de Artes da Maré Espaço fechado de uso privado e uso permanente.

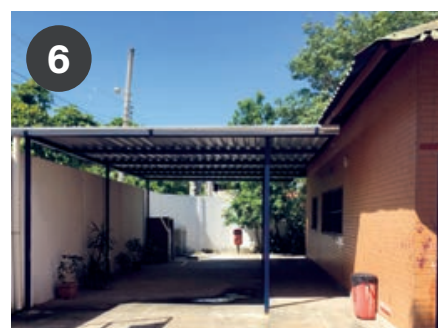

Lona Cultural H. V.

Espaço fechado de uso público e uso permanente.

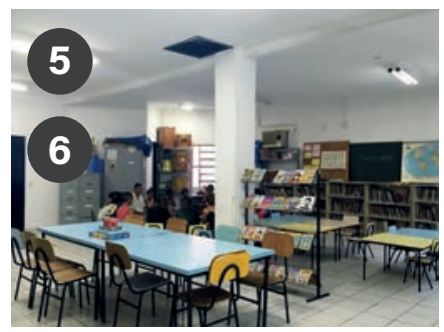

\section{Bibliotecas internas}

Espaços fechado de uso privado e uso permanente. 
Foi possível perceber que a intenção do grupo ao formar o coletivo era realizar atividades com maior autonomia e focadas em arte e cultura no território. Embora a troca com a Redes da Maré fosse constante, visto a proximidade dos atores, havia um grande interesse em atuar de forma independente no território, sem quaisquer tipos de amarras institucionais. Todavia, manter os projetos e atividades do Coletivo ainda era algo complicado, visto que era preciso recorrer a recursos externos e ainda trabalhar, visto que se tratava de uma ação voluntária.

Lino conta que após receberem o prêmio, o grupo se integrou a Redes da Maré e cada um foi atuar em uma parte específica ${ }^{11}$. Aleixo trabalhou por um período no eixo de segurança pública, Lino passou a atuar no eixo de arte e cultura e Lopes permeava todos os eixos através de trabalhos de comunicação como registros fotográficos e de vídeo. Embora a integração a Redes tenha retirado parte da autonomia do Coletivo, a sua inserção trouxe estrutura, organização e recursos, propiciando que muitas atividades com a mentalidade independente de coletivo pudessem ser continuadas. Aleixo e Lino possuem um forte papel nesta linha de pensamento e vêm trazendo propostas mais horizontais a organização junto a novas gerações, incluindo atores como Lopes e outros jovens adultos.

Ao longo da pesquisa foi necessário realizar muitas observações profundas em atividades da Redes da Maré para compreender as relações hierárquicas, os traços institucionais e a dimensão da autonomia neste meio. Na minha perspectiva, a união entre o Coletivo Maré e a Redes da Maré trouxe benefícios para ambos os lados, em que o primeiro recebeu respaldo institucional, recursos e apoio em rede e o segundo ganhou uma frente de ação mais autônoma e criativa, que possuía energia e predisposição para realizar atividades efêmeras em outros espaços do território.

Desta maneira, após muitas trocas com Lino e Lopes, compreendi que a pesquisa, ainda que delimitada a ação de alguns poucos atores específicos, envolvia, em sua essência, mais a Redes da Maré que o Coletivo Maré, visto que seus atores estavam realizando os mesmos tipos de atividade que faziam quando eram Coletivo, agora como organização da sociedade civil. Em razão disso, a pesquisa migrou seu foco do 
Coletivo Maré para a Redes da Maré, mas manteve a parceria com os mesmos atores e nas mesmas atividades que eles já realizavam.

Neste contexto se inserem as minhas vivências, que duraram cerca de um ano e meio de idas e vindas entre São Paulo e o Rio de Janeiro. No capítulo a seguir, narro as experiências que vivenciei na Maré, as técnicas que utilizei e os aprendizados que levantei, corroborando para um entendimento mais profundo sobre a colaboração em design em espaços urbanos complexos. 


\section{CAPÍTULO 3}

\section{Processos de experiências e aprendizados na Maré}

Como visto, o território da Maré carrega uma longa trajetória de resistência na metrópole do Rio de Janeiro, e a Redes da Maré, há mais de uma década, possui um papel fundamental na luta pelos direitos e qualidade de vida dos moradores. Conforme fui me aproximando do território e das pessoas, fui compreendendo a lógica espacial ali existente, de maneira que a minha percepção sobre o local se modificava, criando novas perspectivas a cada momento da pesquisa. Neste sentido, este capítulo tem como intuito apresentar as minhas vivências em campo entrelaçadas por alguns aportes teóricos que me auxiliaram neste processo.

Após a minha visita inicial, mencionada na introdução, retornei a Maré apenas no segundo semestre do ano de 2016. Optei por iniciar os processos de campo após revisitar algumas abordagens de trabalho e compreender como a minha postura seria melhor colocada, isto é, como observadora, participante ou possivelmente propositora. Para tanto, no próximo tópico descrevo algumas abordagens pesquisadas e escolhidas como suporte.

Tendo em mente algumas possíveis abordagens para ação na Maré, iniciei o processo sem saber com exatidão como tudo ocorreria. Ao final, foi possível concluir três fases de trabalho, que serão narradas cronológica e sequencialmente, já que cada uma proveu insumos para a seguinte por meio de reflexões acerca do processo colaborativo. As três fases, apresentadas após o item '3.1 Escolha de abordagens', foram divididas em: 


\subsection{Visitas ocasionais: aprendendo com quem já faz}

\subsection{Imersão no Complexo da Maré: reconhecendo o território}

\subsection{Da observação para a ação: a proposição em demandas locais}

Permeando cada fase, apresento os dois últimos pontos da estrutura de Malinowski, citadas no primeiro capítulo: (2) Os imponderáveis da vida real e os tipos de comportamento, isto é uma compilação de relatos vividos baseados em interações, trocas e aprendizados com pessoas do local, o cotidiano da iniciativa, as atividades realizadas, os participantes e a relação de pertencimento com a Maré; e (3) Uma compilação de depoimentos etnográficos, narrativas características e pronunciamentos típicos, isto é, a linguagem, costumes e rituais, entre outros. Visto que as vivências em campo foram extremamente ricas, optei por deixar o entrelaçamento das experiências com os aportes teóricos no capítulo quatro, com o intuito de construir relações entre a teoria e a prática e promover reflexões sobre o processo de colaboração em design.

\subsection{Escolha de abordagens}

Em revisões teóricas preliminares, ainda no primeiro semestre do ano, me deparei com a pesquisa de doutorado da pesquisadora Chiara Del Gaudio (2014), que acompanhou o trabalho de uma ONG também no Complexo da Maré. A autora desenvolveu uma pesquisa qualitativa em âmbito prático, na qual utilizou abordagens como o Design Centrado no Usuário ${ }^{120}$ e Design para Inovação Social ${ }^{121}$, também no Complexo da Maré. A partir destas abordagens, a autora tomou para si o desafio de compreender o contexto e encontrar comunidades criativas e redes colaborativas que promoviam a transformação daquele espaço a partir de uma demanda local: o uso de uma praça central na Maré.

\footnotetext{
120. Design Centrado no Usuário - ou Human Centered Design, sigla HCD - é a metodologia utilizada pela empresa norte americana IDEO, na qual o foco do projeto é sempre o usuário e as suas necessidades. A empresa disponibiliza em sua página web o seu Design Kit, que é uma caixa de ferramentas online com métodos para o desenvolvimento de projetos. Cf. IDEO. What is Human Centered Design? Página com descrição sobre o HCD. Disponível em: <http://www.designkit.org/ human-centered-design>. Acesso em: 12 Set. 2017.

121. Segundo o pesquisador italiano Ezio Manzini (2015, p. 62, tradução nossa), estudioso do tema Inovação Social, o design para inovação social "é tudo o que o profissional experiente pode fazer para ativar, sustentar e orientar processos de mudança social em direção à sustentabilidade".
} 
Ainda que ONG estudada por Del Gaudio representasse um caso nítido de Inovação Social ${ }^{122}$, uma vez que se configurava como uma organização de base (traduzida da língua inglesa 'grassroot organization') formada por “redes de ativistas e organizações que geram novas soluções (...) que respondem à situação local e aos interesses e valores das comunidades envolvidas" ${ }^{\prime 23}$, seu processo sofreu com uma série de ruídos. Questões como conflitos e violência, demandas sociais complexas e segregação espacial urbana foram alguns motivos que dificultaram a sua atuação em campo durante seu processo e inviabilizaram a construção de um projeto colaborativo, obrigando-a atuar de forma fragmentada, utilizando outras abordagens para participação e engajamento.

Ao transferir os aprendizados de Del Gaudio para a minha própria pesquisa, compreendi que meu foco durante as vivências em campo poderia ser pautado em abordagens mais maleáveis e experimentais, em que a ação do design ocorresse a partir de demandas e urgências cotidianas levantadas por representantes locais. Neste sentido, após conversas com a professora Dra. Zoy Anastassakis, fui introduzida às abordagens design anthropology (DA) e codesign.

O DA, discutido em diversos posicionamentos por pesquisadores do Reino Unido e da Escandinávia, conjuga práticas antropológicas com práticas do design junto a usuários e "argumenta por um conceito aberto de design que dá espaço para esperanças e sonhos e para a dinâmica improvisatória cotidiana" (Gatt; Ingold, 2013, p. 141, tradução nossa) $)^{124}$. Tratando-se de uma abordagem que não coloca a etnografia como mera ferramenta de observação e coleta de dados para uma ação propositiva de design, esta abordagem visa uma correspondência entre os dois campos. Segundo os pesquisadores Mette Kjærsgaard e Ton Otto (2012, p. 188, tradução nossa) ${ }^{125}$

122. Para Manzini (2008, p. 61), a Inovação Social a refere-se a "mudanças no modo como indivíduos ou comunidades agem para resolver seus problemas ou criar novas oportunidades. Tais inovações são guiadas mais por mudanças de comportamento do que por mudanças tecnológicas ou de mercado, geralmente emergindo de processos organizacionais 'de baixo para cima' em vez daqueles 'de cima para baixo'.

123. Ibid., p. 80. No original: "networks of activists and organizations generating (...) solutions that respond to the local situation and the interests and values of the communities involved".

124. No original: "we argue for an open-ended concept of design that makes allowance for hopes and dreams and for the improvisatory dynamic of the everyday".

125. No original: "It is not about providing detailed descriptions of current user practices as fuel for 
não se trata de prover descrições detalhadas de práticas atuais de usuários como combustível para a imaginação de futuros produtos de designers, mas sim sobre explorar e trabalhar com conceituações e reenquadramento de relações entre pessoas e coisas, a fim de ressaltar o potencial de elaboração de ambos designers e usuários.

A intenção é que um campo se reinvente no outro durante vivências diárias com "habitantes do mundo", que vivem a constante criação dos tipos de ambientes que desejam viver ${ }^{126}$. Assim, a noção preconcebida de design - tradicionalmente conhecida rompe com os eixos de tempo e espaço impostos pela atividade projetual, deslocando o entendimento de 'objetos', projetados com um fim, para 'coisas', que ganham outros significados de acordo com seus usos (Ingold, 2012; Latour, 2009) ${ }^{127}$. Segundo Gunn e Donovan (2012, p. 1), trata-se de um processo de design que não impõe términos e fechamentos, mas que permite que a vida cotidiana continue.

A atitude de colocar participantes não apenas como realizadores do processo, mas como aqueles que darão continuidade a ele ao transformar objetos em coisas, abre possibilidades para um exercício de correspondência. Os autores ${ }^{128}$ propõem um conceito de design que quer trabalhar com as diferenças de ambos os lados, focando no engajamento de um com o outro, para "encontrar caminhos de imaginar-se no mundo de outra pessoa. Isto, no entanto, não quer dizer que os indivíduos participantes querem ser o outro, mas que querem aprender com as práticas do outro a fim de construir

the designers' imagination of future products, but rather about exploring and working with conceptualizations and re-framings of relations between people and things, in order to enhance the crafting potential of both designers and users".

126. Ingold; Gatt, op cit., p. 142.

127. Apesar dos autores divergirem quanto ao entendimento da relação entre objetos e coisas, visto que Latour (2009) apresenta um posicionamento pautado no conceito de rede e Ingold (2012) se apoia no conceito de malha, ambos abraçam o deslocamento do objeto para coisa, com o sentido que o usuário traz vida aos objetos quando os utiliza, transformando-os em coisas. 
uma relação mais próxima entre estas"129. Este rumo indica "a construção de relações mais estreitas entre usar e produzir, projetar e usar, [e] pessoas e coisas (... $)^{130 "}$.

Em paralelo, o codesign almeja a atuação colaborativa durante o processo, por meio da criação de cenários especulativos, experimentações e reflexão. Segundo o Center for Codesign Research (CODE, 2018), de Copenhagen na Dinamarca,

Codesign é a abreviação para design colaborativo. Codesign é a investigação crítica de novas possibilidades, onde diversos parceiros estão ativamente envolvidos em diálogos materiais sobre o que constitui futuros atrativos de diferentes pontos de vista. O Codesign é transdisciplinar em direcionar problemas complexos em que nenhuma disciplina pode ser responsável por dar a resposta. Codesign é construído em tradições do design centrado no usuário, design participativo, critical design e etnografia. ${ }^{131}$

Por outro caminho complementar, Sanders e Stappers (2008, p. 6) desbravaram as múltiplas definições para co-criação e codesign, a começar pela ideia de co-criação pautada no design participativo escandinavo, que sugere "qualquer ato de criatividade coletiva"132, enquanto codesign é por eles indicado como:

(...) a criatividade coletiva à medida que é aplicada em todo o período de um processo de design (...). Assim, o co-design é uma instância específica de co-criação. O co-design refere-se, para algumas pessoas, à criatividade coletiva dos designers colaboradores. Usamos o co-design em um sentido mais amplo para encaminhar a criatividade de designers e pessoas não treinadas em design trabalhando em conjunto no processo de desenvolvimento de design. ${ }^{133}$

129. No original: "engaging with others is finding ways of imagining oneself into another person's world. This however does not mean individuals participating want to be the other. Rather they want to learn from each other's practices in order to build a closer relation between practices."

130. No original: "we would argue that in building closer relations between using and producing, designing and using, people and things (...)".

131. No original: "Codesign is short for collaborative design. Codesign is a critical investigation of new possibilities, where diverse partners are actively involved in material dialogues about what constitutes attractive futures from different points of view. Codesign is transdisciplinary in addressing complex problems where no single discipline can be said to hold the answer. Codesign builds on traditions of user-centered design, participatory design, critical design and ethnography."

132. No original: "The authors take co-creation to refer to any act of collective creativity (...)".

133. No original: "By co-design we indicate collective creativity as it is applied across the whole span 
Para os autores ${ }^{134}$, pensar o codesign como abordagem exige uma revisão na postura de trabalho que o profissional ou pesquisador intenciona adotar, especialmente por exigir que designers reconheçam que todas as pessoas podem ser criativas, dissolvendo a mentalidade na qual designers são especialistas, e a partir de uma revisão sobre quem controla as estruturas de poder, visto que elas devem ser compartilhadas entre os participantes. Para tanto, vale-se da ideia que "estamos nos movendo das categorias de design de 'produtos' para projetar para o propósito das pessoas"135.

A proposta de codesign teve grande aderência durante a minha escolha de abordagens de trabalho, inclusive por conta de reflexões observadas em trabalhos de outros pesquisadores envolvidos com a colaboração em design desde o término da minha graduação. Entre esses cito o seminário 'Entremeios: modos de vida e práticas criativas na cidade' desenvolvido pelo LaDA/ESDI/UERJ em agosto de 2014 no Rio de Janeiro, o qual tive a oportunidade de participar e assistir. Nesta ocasião pude perceber como jovens designers estavam se engajando em práticas colaborativas envolvendo design na cidade, a partir do reconhecimento da criatividade, imaginação e improvisação urbana como meios para o desenvolvimento de projetos. Entre diversas percepções sobre o evento, a de Cristina Ibarra e Zoy Anastassakis (2015) se destacou pela sua contribuição em minha pesquisa de mestrado. Segundo autoras ${ }^{136}$,

Quando o design está no meio, articula, junta, inclui, engaja, propulsiona, provoca. Quando está no centro, declara, prescreve, impõe. A abertura do design através de métodos colaborativos, (...), propicia o conhecimento do que as pessoas esperam do futuro e o que têm como prioridade, para assim construir juntos situaç̃̃es preferidas ou mundos desejados, fazendo desta maneira uma prática do design mais democrática e participativa.

of a design process, as was intended by intended by the name of this journal. Thus, co-design is a specific instance of co-creation. Co-design refers, for some people, to the collective creativity of collaborating designers. We use co-design in a broader sense to refer the creativity of designers and people not trained in design working together in the design development process".

134. Ibid., p. 9.

135. Ibid., p. 10. No original: “(...) we are moving from the design of categories of 'products' to designing for people's purposes".

136. Ibid., p. 3. 
Além do DA e codesign, adotei também ferramentas da abordagem brasileira design social participativo ${ }^{137}$, desenvolvida e estudada desde os anos 1980 por professores da PUCRio, a qual eu já possuo familiaridade desde a graduação. A abordagem possui uma série de pontos de encontro com as duas anteriormente citadas, especialmente no entendimento do ponto de vista do outro e o uso de experimentações e protótipos colaborativos.

O design social participativo vem de um contexto acadêmico em que as ciências humanas eram seu lugar de nascimento, isto é, o Centro de Teologia e Ciências Humanas (CTCH) da PUC-Rio. Tal base humanista, somada com a atuação de professores dos campos da arquitetura e do desenho industrial e a participação da antropóloga Lélia Gonzalez ${ }^{138}$, permitiu que a abordagem de trabalho colocasse os alunos para fora da universidade em suas aulas de projeto. Com efeito, o processo participativo emergiu de maneira orgânica, pois os resultados dos projetos com duração de um semestre não eram apenas fruto da atuação de alunos, mas também das usuários com quem eles acompanhavam durante o período ${ }^{139}$.

Tal abordagem dá voz ao outro com quem se trabalha, integrando-o ao projeto por meio de ferramentas comuns ao campo da antropologia, como cadernos de campo, desenhos, registros fotográficos, conversas e observação. Para além dessas, a experimentação é o traço marcante no processo de trabalho: é por ela que os alunos conseguem levar suas ideias de objetos por eles construídos a campo, para que sejam testadas pelos usuários parceiros no processo e transformadas em novas coisas.

Levando em consideração as abordagens de trabalho escolhidas, notei que a vivência em campo seria o único meio de levantar possíveis respostas para as minhas indagações e compreender como estes caminhos pesquisáveis poderiam me auxiliar. Em razão disso, em cada fase tive a chance de utilizar caminhos das abordagens citadas, como a observação participante nas primeiras duas fases, comum ao DA, o registro de campo em um diário de bordo em todas as fases, comum ao design social participa-

137. Cf. Couto, 1991.

138. Cf. Montuori in Braga; Ferreira, 2017, p. 79-99.

139. Informações fornecidas por José Mendes Ripper durante entrevistas nos dias 7 de maio de 2016 (duas horas de duração), 3 de junho de 2016 (três horas de duração) e 19 de julho de 2016 (uma hora e meia de duração), no Rio de Janeiro. 
tivo, a experimentação e reflexão nas segunda e terceira fase, comum ao codesign, e outras que mencionarei ao longo das narrativas. Assim, apresento a primeira fase, na qual realizei visitas ocasionais na Maré e fui conhecendo aos poucos meus parceiros em campo por meio da observação participante.

\subsection{Visitas ocasionais: aprendendo com quem já faz}

Retornei ao Rio de Janeiro no início do mês de junho de 2016 com a intenção de visitar a Maré e acompanhar atividades de curta-duração coordenadas por Lino em parceria com outros articuladores e parceiros. Neste primeiro momento, minha intenção com estas visitas era apenas observar e participar do que era realizado pelos coordenadores e participantes, a fim de tentar compreender como se davam as inter-relações e os usos dos espaços no território.

A minha primeira visita ocorreu no dia dez de junho de 2016, quando fui junto com uma colega externa a Maré para o terceiro dia de atividade do evento $1^{\underline{a}}$ Rodada de Cicloativismo da Maré, que já acontecia desde o dia oito de junho entre às dezesseis e vinte horas. Era uma sexta-feira e fazia um dia agradável no Rio de Janeiro, não chovia e não estava muito calor. Como ensinado por Lino, peguei o metrô na estação Botafogo, me encontrei com a minha colega na estação Largo Machado e seguimos até a Cidade Nova. Chegando lá, saímos do metrô, que desemboca em uma larga passarela que cruza a Avenida Presidente Vargas e possui três pontos de descida para a rua: o primeiro no ponto de ônibus para quem vai em direção a Zona Norte e outras destinações, o segundo para quem pega ônibus na direção contrária, isto é, para o Centro e a Zona Sul, e o terceiro que desemboca na entrada da Prefeitura do Rio de Janeiro.

Já familiarizadas com o percurso, descemos no ponto que ia em direção a Zona Norte, e ficamos aguardando algum ônibus 'parador', ou seja, que parasse em todos os pontos da Avenida Brasil. Ainda em dúvida sobre os números dos ônibus, observei que as pessoas naquele ponto sempre perguntavam aos motoristas se o veículo ia para o seu destino de interesse e adotei a tática com os ônibus que iam passando, até aparecer algum que nos servisse. Seguimos no ônibus conversando e tudo parecia normal, até entrarmos na Avenida Brasil (figura 11). 


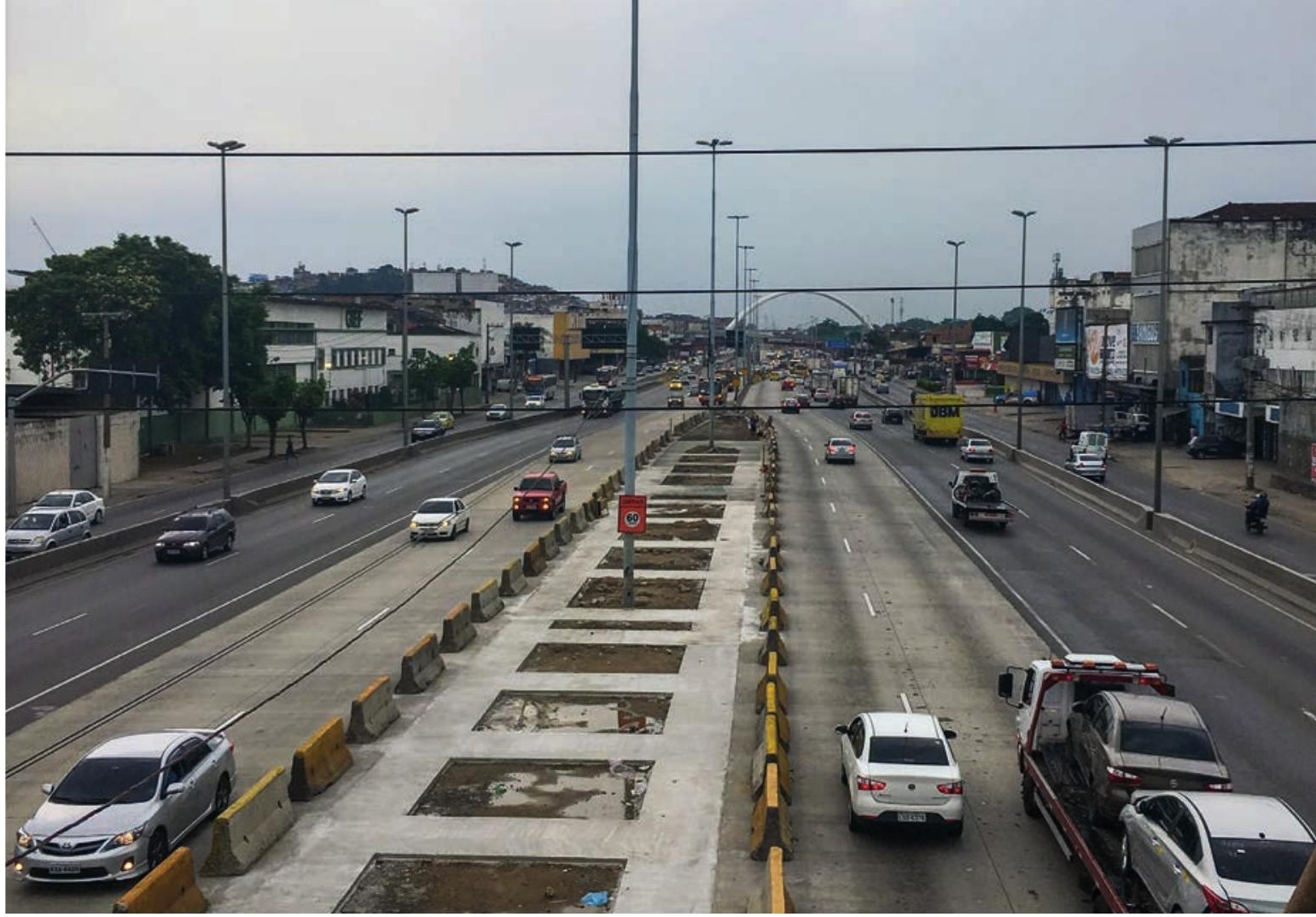

Figura 11: Vista da Avenida Brasil na Passarela 8. Fonte: autora da dissertação, 2017.

A Avenida Brasil é gigantesca. São pelo menos seis faixas em uma direção e seis em outra, além de faixas adicionais externas para quem precisa entrar ou sair de rotatórias, desvios ou retornos. Os veículos correm rapidamente e há pouquíssima circulação de pedestres ao longo da via, com exceção dos locais com pontos de ônibus principais, como a entrada da Vila do João, na altura da passarela seis, o ponto em frente à Escola Municipal Bahia, na altura da passarela oito, o ponto da Rua Teixeira Ribeiro, na altura da passarela nove, e o meu ponto de destino na Rua Bittencourt Sampaio, anterior a passarela dez.

Estar em companhia foi uma decisão positiva, pois fazia com que eu me sentisse mais segura no deslocamento, visto que eu provavelmente retornaria a noite já sem luz do dia. Descemos no ponto de ônibus da Rua Bittencourt Sampaio e, dessa vez, não fomos para o Centro de Artes da Maré, uma vez que a atividade ocorreria na Lona Cultural Herbert Vianna. Logo na entrada da rua há um ponto de moto-taxi, onde ficam vários motoristas aguardando por pessoas que querem se deslocar dentro da Maré. Subimos cada uma em uma moto e fomos até a Lona Cultural pelo preço de três reais. O moto-taxista me perguntou se eu era da Maré e respondi que era de fora 
e estava ali para participar de uma atividade na Lona Cultural promovida pela Redes da Maré, na qual eu conhecia Geisa Lino e Douglas Lopes. Na sequência, o motorista, que eu não sabia o nome, me respondeu:
Ah sim, a Redes, conheço o trabalho deles, é muito legal. A Geisa e o Douglas não sei quem são, mas sabe, a Maré é enorme... Inclusive, se tu vai pra Lona Cultural, porque não desceu no ponto da passarela oito? É na altura da Lona, seria bem mais fácil, até porque a gente não gosta de circular para outros lados, porque tem fronteira, daí a gente prefere ficar só dentro da área que a gente trabalha... (Comunicação oral).

Neste momento, alguns nós já se desfaziam na minha cabeça. Era por este motivo que o outro moto-taxista, que citei na introdução, não queria me levar até a Lona Cultural. Já nesse instante comecei a perceber como era forte a demarcação de fronteiras no território, a ponto que pessoas da própria Maré não conheciam outras partes do local em razão da segregação estabelecida pela violência proveniente de conflitos envolvendo facções criminosas, milícias, $\mathrm{PMER}{ }^{140}$ ou $\mathrm{BOPE}^{141}$.

Chegamos à Lona, descemos da moto na Rua Ivanildo Alves e caminhamos cerca de vinte metros até a sua entrada lateral que fica na Rua C, localizada na favela Nova Maré. Já ali era possível ver as casas de tijolinho vermelho típicas da Nova Maré, distintas em relação às outras favelas próximas - Baixa do Sapateiro, Morro do Timbau e Nova Holanda. Entramos na Lona e nos deparamos com toda a equipe vestindo camisas amarelas com os dizeres 'Projeto Maré Sem Fronteiras'. Cumprimentei Lino, que estava animada na montagem de um triciclo, desenvolvido a partir de uma bicicleta de carga (figura 12), que era transformado em um triciclo multimídia, que contaria com equipamento de som, projetor, computador, iluminação tipo LED colorida, e uma plaquinha iluminada escrita 'Ciclo Maré'.

Ficamos conversando com Lino sobre a proposta do evento, que estava em seu terceiro dia de encontros, incluindo atividades como oficina de conserto de bicicletas com crianças e jovens que frequentavam a Lona, projeção de filme sobre mobilidade urbana, roda de debate sobre a mobilidade e o deslocamento na Maré, entre outras. 


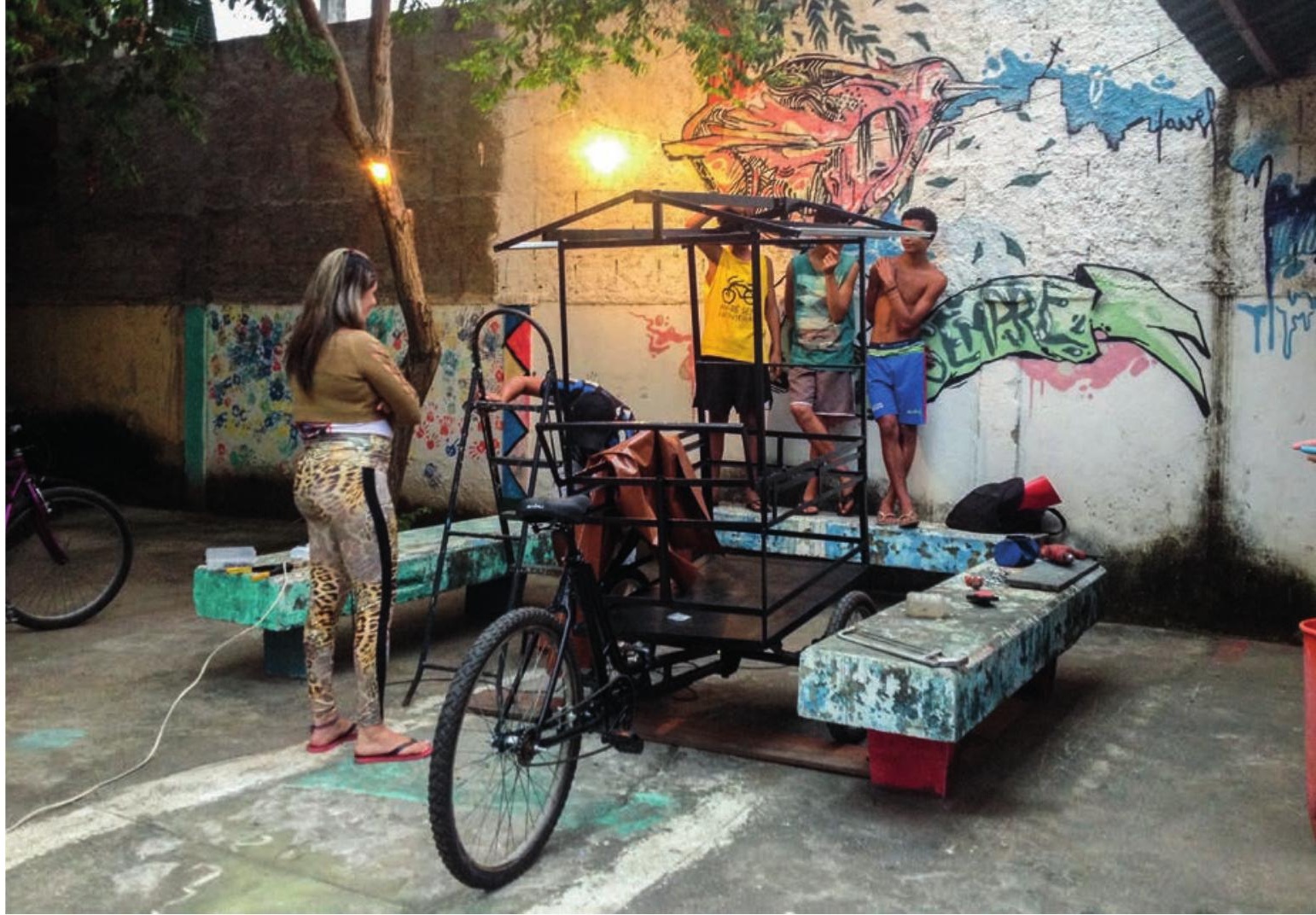

Figura 12: processo de construção do triciclo multimídia a partir de uma bicicleta de carga. Fonte: fotógrafo Douglas Lopes, 2016.

Na ocasião, aproveitei para perguntar sobre a origem da proposta da Rodada de Cicloativismo e entender o foco de trabalho de Lino e outros atores ali presentes e desta maneira conheci o Projeto Maré Sem Fronteiras, embora ainda não entendesse com clareza todas as formas de ação da Redes da Maré naquele território.

O Maré Sem Fronteiras nasceu em 2013 no eixo de Desenvolvimento Territorial da organização e tem como propósito trabalhar a influência que as fronteiras estabelecidas pelos conflitos geram em crianças e jovens de duas comunidades: a Nova Holanda, dominada pelo Comando Vermelho, e a Nova Maré, dominada pelo Terceiro Comando Puro. Segundo Lino, a influência das fronteiras na formação infanto-juvenil impactava diretamente o comportamento das crianças e jovens, de modo que estas incorporavam e reproduziam atitudes segregadoras, gírias e formas agressivas de agir, ao ponto de umas brigarem com as outras.

O projeto, na época coordenado por Suélen Brito, nasceu com intuito de trabalhar a ideia de fronteiras e transformar a percepção e a cultura de violência que impactava aqueles jovens, por meio da arte, da música, do esporte e, principalmente, da edu- 
cação. Segundo a página da Redes da Maré (2018), o projeto se caracteriza por “(...) romper demarcações simbólicas e geográficas que fazem parte do cotidiano dos moradores da Maré", que incentivam

(...) desde seu início a mobilidade da população local entre diferentes comunidades da região, apostando na valorização da memória e da identidade do território. Para isso, são oferecidas para crianças e adolescentes oficinas artísticas regulares de Azulejaria, Desenho, Fotografia, trabalhando narrativas nascidas de reflexões sobre histórias e vivência locais, medos e representações simbólicas da Maré.

Ao ampliarmos nossa perspectiva por um breve instante, é interessante notar que em meados de 2009, a Prefeitura do Rio de Janeiro lançava o plano 'Rio Capital da Bicicleta $^{\prime 142}$, que se objetivava atingir a meta de 450 quilômetros de ciclovias e ciclofaixas por toda a cidade do Rio de Janeiro, concluídos entre a Copa do Mundo de 2014 e os Jogos Olímpicos de 2016. A Maré entrou neste plano como uma das áreas que recebeu este suporte, porém assim como o resto da cidade, sua malha cicloviária fora desenvolvida "sem infraestrutura, sem ligação com outras vias de transporte, sem sinalização e sem manutenção", como apontado pelo Data Labe (2017), laboratório de pesquisa independente. Segundo o Data Labe ${ }^{143}$, cerca de $81 \%$ das pessoas na Maré sabem conduzir a bicicleta, enquanto apenas 35\% sabem conduzir motocicleta e somente 30\% sabem conduzir carro. Neste ínterim, dados levantados pelo Data Labe (2017) nos contam que

Em articulação com a extinta Secretaria de Meio Ambiente (Smac) - atual Secretaria de Conservação e Meio Ambiente (Seconserma) - e a Gerência de Projetos para Ciclovias da cidade, a Redes viu a possibilidade de botar em prática a discussão sobre mobilidade feita durante o fórum. Depois de diversas reuniões foi acordada a implementação de $22 \mathrm{~km}$ de ciclovias nas 16 comunidades do Complexo. A organização agiria como mediadora entre a Administração Regional e as associações de moradores para garantir que a obra acontecesse. Porém, antes mesmo que as faixas começassem a ser pintadas, o administrador regional foi substituído, após romper com a gestão do prefeito Eduardo Paes, as negociações que haviam sido feitas até então

142. Rio, Capital Urbana da Mobilidade por Bicicleta. Artigo da extinta Secretaria Municipal de Meio Ambiente (SMAC). Disponível em: <http://www.rio.rj.gov.br/web/smac/exibeconteudo?article-id=756384>. Acesso em: 11 Out. 2017.

143. Idem. 
perdidas e a Redes da Maré ficou impossibilitada de exercer a articulação. Os 10 meses de duração da obra (entre março de 2015 e janeiro de 2016) foram então caracterizados por uma série de entraves. A nova Administração Regional excluiu a sociedade civil organizada do processo. A partir daí o projeto original foi desfeito, os caminhos alterados e as obras dificultadas por desmandos dos grupos civis armados* que regulam o Complexo. Nos territórios comandados pelo Terceiro Comando Puro, por exemplo, as faixas não puderam ser pintadas de vermelho, cor que faz referência ao Comando Vermelho.

É neste contexto que discussões sobre mobilidade se inserem na Redes da Maré e no Projeto Maré Sem Fronteiras, que já em 2013 contava com uma ampla quantidade de bicicletas que estimulavam o transporte e atividades envolvendo a ciclo mobilidade no território. Coordenadora das bicicletas e das rodadas de cicloativismo, Lino buscou por meio desses eventos promover reflexões sobre o território, integrá-lo e estimular os grupos de jovens a se engajarem com o meio de transporte. Assim, a $1^{\underline{a}}$ Rodada de Cicloativismo era realizada neste âmbito, junto a uma equipe que contava com vários parceiros, os quais apresento no próximo tópico.

\subsubsection{Conhecendo os parceiros da Redes da Maré e suas formas de fazer}

Ainda no mesmo evento, dialoguei com algumas figuras importantes nesta narrativa: Geisa Lino, coordenadora do espaço e produtora cultural; Douglas Lopes, designer e fotógrafo da Redes da Maré; Renan Braga, cicloativista carioca e parceiro da organização; Carlos Marra, gestor e funcionário da Lona Cultural; e Gilberto Vieira e Clara Sacco, coordenadores do Data Labe e articuladores da parceria com o laboratório de fabricação digital Olabi Makerspace. Na próxima imagem (figura 13) apresento a equipe envolvida na atividade. Evidentemente, muitos parceiros irão aparecer ao longo da narrativa, porém apresento estes que foram marcantes na compreensão inicial do território e da atuação da Redes da Maré.

Foi interessante notar como atores tão diferentes se reuniam por um propósito comum: articular o território de maneira lúdica e, ao mesmo tempo política, visto que queriam colocar luz sobre a questão da mobilidade sobrepondo as fronteiras. Neste primeiro momento de encontro procurei observar, acompanhar a atividade e compre- 
da mobilidade integradora no território, Braga veio de fora da Maré a convite de Lino na intenção de contribuir com as atividades e participar da Rodada de Cicloativismo.

Já Marra, funcionário da Lona Cultural, solucionava problemas direcionados ao espaço da lona, seu uso e funcionamento, incluindo seu horário de fechamento naquele dia, no qual o triciclo deveria partir antes das seis horas e trinta minutos da tarde, quando fecha o local.

Vieira e Sacco, que tive menor oportunidade de conversa por terem chegado na hora que o passeio começaria, também eram peças chaves naquele movimento. Parceiros de Lino e também de fora da Maré, os dois atuam no Data Labe desde 2015, um laboratório de dados e narrativas da favela da Maré originado no Observatório de Favelas e atualmente autogerido. Seu trabalho consiste no levantamento e compilação de dados sobre o território, enriquecendo a sua produção de conteúdo. A partir de uma parceria com o grupo Olabi Makerspace, laboratório de fabricação digital carioca, a dupla viabilizou a ponte entre as discussões da favela e as novas ferramentas que vêm aliando a tecnologia à transformação social ${ }^{144}$.

Além desses, outras pessoas estavam presentes: cicloativistas visitantes, participantes da própria Maré interessados no evento, além de crianças (entre 5 a 9 anos) e jovens (entre 10 a 14 anos) da Nova Maré que participam ativamente das atividades realizadas na Lona. Embora fosse meu primeiro dia, foi muito rico passar à tarde com aquelas pessoas, começar a compreender os desdobramentos do trabalho realizado pelos parceiros que estabeleci na pesquisa e perceber como as redes eram feitas naquele espaço. Após muitas conversas sobre mobilidade e o deslocamento na Maré, o triciclo multimídia ficava pronto e preparado para percorrer o território (figura 14): sairia da Lona Cultural pela Rua Ivanildo Alves, bem em frente ao valão, um canal de água poluída próxima a um espaço de despejo de lixo que demarca uma importante fronteira entre a Nova Holanda e a Nova Maré. Em seguida, entraria na Rua Principal e seguiria até a Praça do Parque União, próxima a colônia de pescadores da comunidade.

144. Olabi Makespace. Página Web da organização. Disponível em: < https://www.olabi.org.br/>. Acesso em: 5 Jan. 2018. 


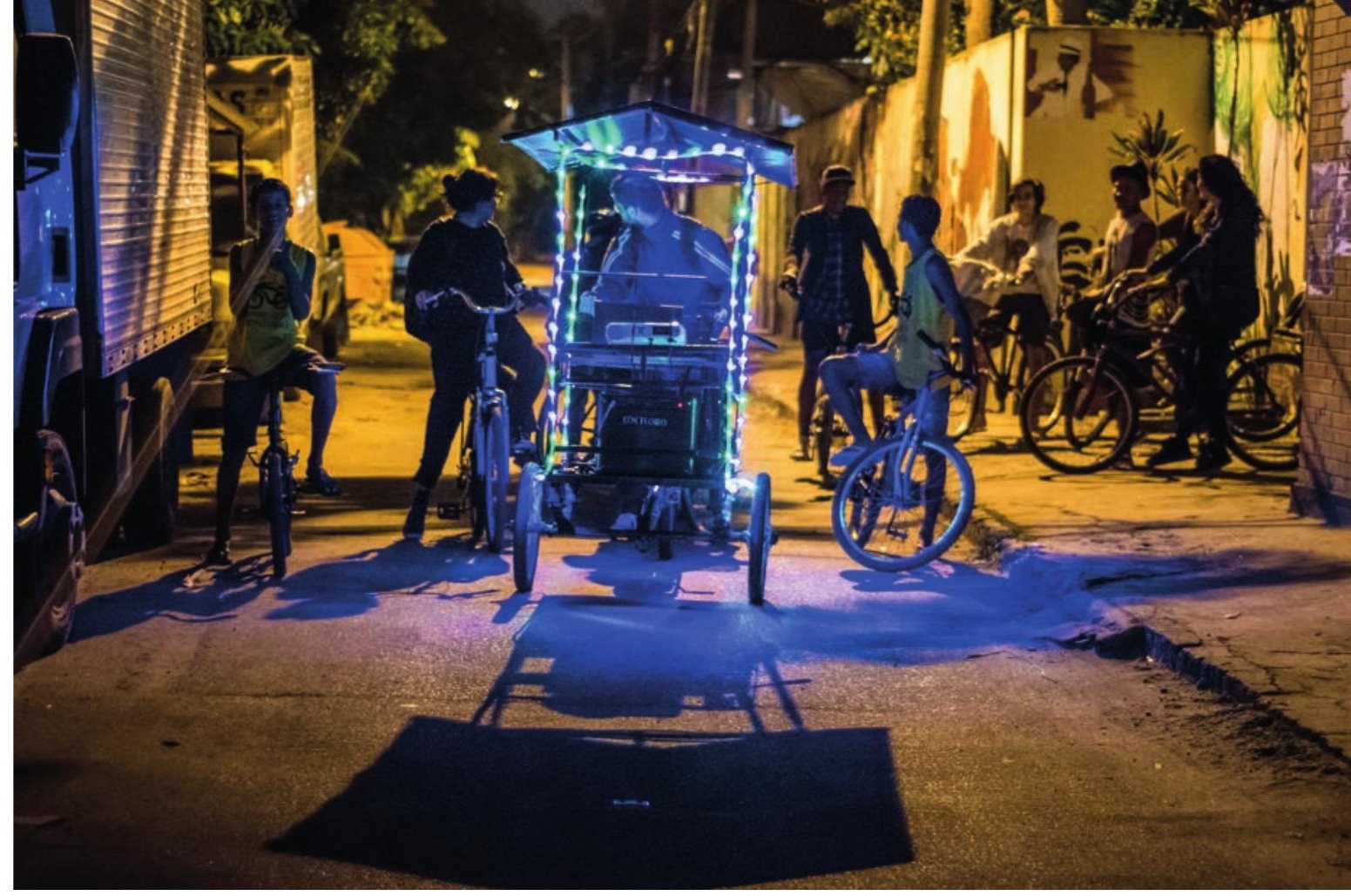

Figura 15: grupo preparado para o passeio ciclístico ao redor do triciclo multimídia. Fonte: fotógrafo Douglas Lopes, 2016.

aqueles elementos humanos e não humanos, havia ao mesmo tempo uma ordem, em que os desvios eram práticas cotidianas e a desordem era ao mesmo tempo ordenada.

Pedalamos todo o trajeto até chegarmos à Praça do Parque União, comunidade que fica depois da Nova Holanda no sentido para a Ilha do Fundão. Próxima à colônia de pescadores do Parque União, na qual a atividade econômica é ainda recorrente, a praça era relativamente ampla e cimentada, contando com duas pistas de skate, quadra e área aberta. No local, outras atividades aconteciam em concomitância, entre elas uma exposição de fotos do Mão na Lata - projeto de fotografia analógica em lata, coordenado pela designer e fotógrafa Tatiana Altberg - e um evento de jovens feministas da Maré, que realizaria um debate sobre sexualidade, funk e favela. Ao chegarmos, Lino e todos envolvidos já se integraram naturalmente às atividades da praça. Ficamos conversando em rodas e falando sobre a experiência vivenciada, enquanto o triciclo era posicionado de frente ao muro da pista de skate, a fim de exibir um vídeo para o público presente.

O vídeo tinha como intuito apresentar entrevistas sobre empoderamento de cantores do funk e suas relações com a favela, política e sexualidade. Entre as conversas com Lino, ela comentou: "nós gostamos de trabalhar em conjunto com outros grupos que 
desejam fazer coisas, especialmente envolvendo a produção cultural" ${ }^{145}$ Além disso, notei como o ciclismo é uma questão realmente vital para eles, pois para Lino "permite que eles cruzem fronteiras cruzadas e rompam barreiras dentro da favela" ${ }^{146}$.

Após um tempo acompanhando e conversando com algumas pessoas presentes, eu e minha colega notamos que eram nove horas da noite e que era necessário ir embora, pois faríamos todo o trajeto de retorno que nos levaria ao menos 45 minutos. Mas como voltar para o Centro de Artes? Nascia nesse momento meu primeiro embate com o território, a minha dificuldade de deslocamento e falta de conhecimento para ter autonomia no local. Pedi ajuda a Lopes, que pediu a um dos meninos que frequentava a Lona, um rapaz que tinha entre catorze e dezesseis anos, que nos levasse de volta até o Centro de Artes, onde deixaríamos as bicicletas emprestadas, atravessaríamos a passarela e pegaríamos algum ônibus para retornar.

O caminho sinuoso e desconhecido da praça até o ponto de ônibus parecia muito distante, especialmente por passarmos por vielas e becos, que apesar da quantidade de pessoas na rua, especialmente crianças brincando, eram desconhecidos por mim naquele momento. Chegamos ao Centro de Artes, deixamos as bicicletas e retornamos para a Zona Sul utilizando um ônibus que nos deixou na Lapa, próximo à estação de metrô Cinelândia no Centro do Rio de Janeiro, onde entramos e retornamos para nossas casas.

Após esta primeira visita, retornei a Maré novamente para a 2 a Rodada de Cicloativismo que ocorreu nos dias quinze, dezesseis e dezessete de setembro, contando agora com outros parceiros e outras atividades. Desta vez me preocupei em participar de todos os dias de evento a fim de conhecer melhor o território e as pessoas envolvidas, intencionando iniciar um diálogo maior sobre o trabalho realizado. Em razão disso, cheguei ao Rio de Janeiro no dia catorze de setembro de 2016, uma quarta-feira, e já no dia seguinte fui para o primeiro dia de atividade.

Mais uma vez, parti de Botafogo, desta vez sozinha, peguei o metrô até a Cidade Nova, desci as escadas, peguei o primeiro 'parador' e fui em direção ao Centro de Artes da Maré. Cheguei ao local por volta das três horas da tarde e me deparei com 


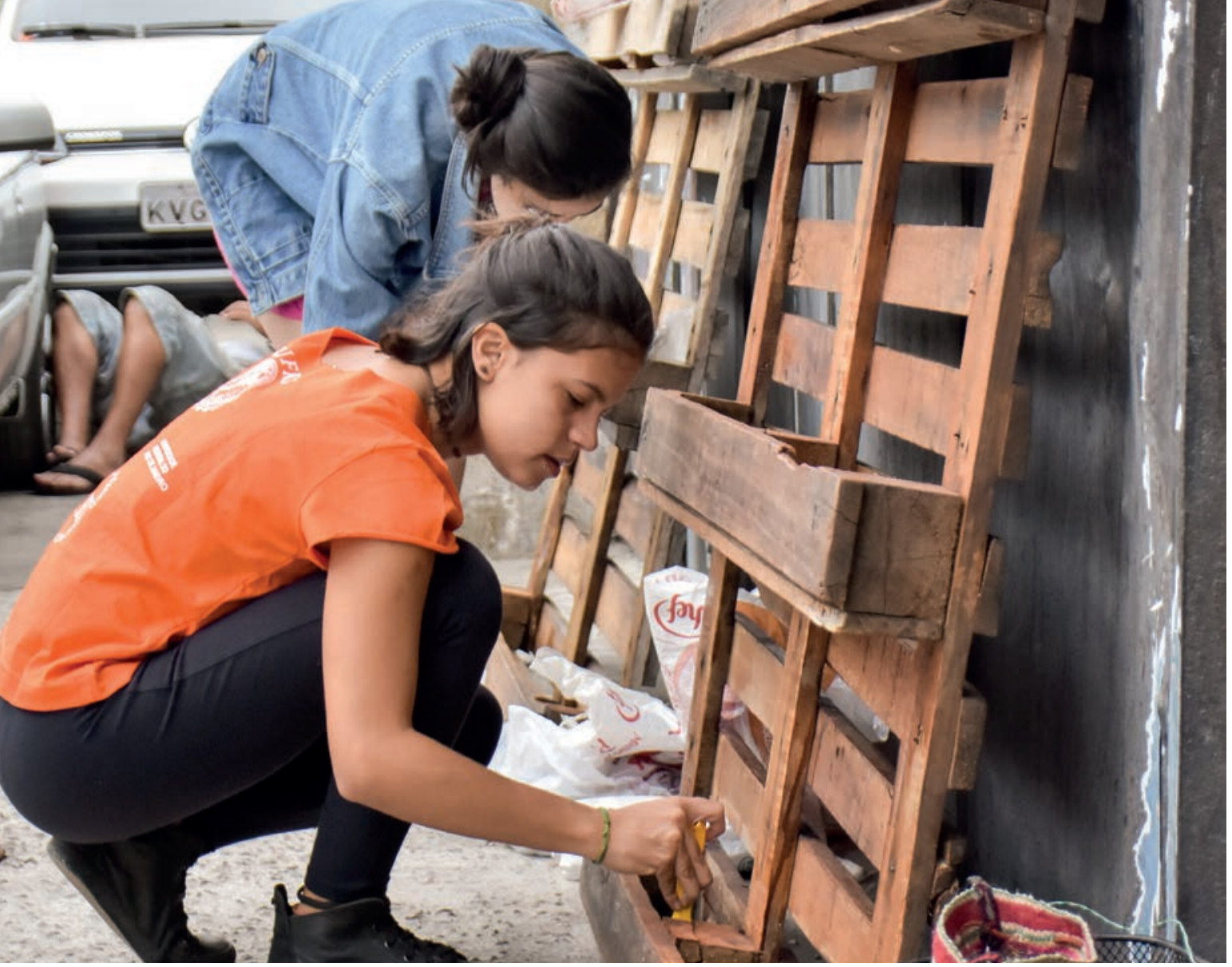

Figura 17: transformando pallets de madeira em um jardim vertical. Fonte: fotógrafo Douglas Lopes, 2016.

extensão universitária da Faculdade de Ciências Biológicas da Universidade Federal do Rio de Janeiro (UFRJ), que trabalham em parceria com a Redes da Maré desde $2011^{148}$. Notei que todos ali eram relativamente jovens, com idade entre vinte e trinta anos e estavam empenhados nas ações que faziam.

Assim, entrei no Centro de Artes, cumprimentei os funcionários na recepção, observei seu interior calmamente, andei por seus espaços - dois galpões enormes e amplos - e, em seguida, fui me integrar à atividade do Muda Maré com o intuito de conhecê-los e participar no que pretendiam construir, isto é, um jardim vertical de pallets de madeira que contaria com sementes e plantas de várias espécies trazidas pelos integrantes. Tratando-se do primeiro dia, o passo inicial era preparar os pallets para que pudessem ser pendurados em uma parede adjacente ao portão do CAM (Figura 17).

148. Muda Maré - Educação Ambiental e Agricultura Urbana. Blog do projeto online e página do facebook. Disponível em: < http://mudamare.blogspot.com.br/2011/o5/o-que-e-esse-projeto.html?view=sidebar $>$ e < https://www.facebook.com/mudamare/>. Acesso em: 12 de Jan. 2017. 
Auxiliei no processo de desmontagem e limpeza dos pallets e fiquei observando todos trabalhando de forma coletiva, cooperando e utilizando ferramentas de marcenaria como martelos e serras. Apresentei-me a dois integrantes do grupo, receptivos e simpáticos, que perguntaram o que eu fazia ali e se era a minha primeira vez em atividades da Redes da Maré e, na sequência, respondi que estava ali para realizar a minha pesquisa de mestrado, interessada em ver pessoas realizando projetos como designers, embora não fossem designers de formação. Os integrantes me deram espaço para participar da atividade que estavam realizando e, entre conversas, me contaram sobre a sua participação no Muda Maré, a ponte existente entre a universidade e a Redes da Maré, e a atuação de longo prazo, na qual o grupo realizava atividades todas as sextas-feiras no período da tarde para crianças que frequentavam a Lona Cultural.

Neste sentido, notei que embora eu tivesse conseguido me expressar acerca do meu trabalho, havia uma grande dificuldade da minha parte em abordá-lo no âmbito da observação participante, meio que vinha utilizando nesta primeira fase de pesquisa de campo - descrita na introdução. No entanto, procurei observar tudo que era possível, das características espaciais às interações humanas e não humanas, e registrar tudo que fosse percebido, como a movimentação frequente de entrada e saída do Centro de Artes e as aulas que lá ocorriam, as pessoas usando o espaço externo em frente a vários veículos abandonados, a passagem de pessoas entrando e saindo da Maré na Rua Bittencourt Sampaio, entre outras observações.

Ao final do dia, quando os pallets já estavam prontos, integrantes do Muda Maré passaram verniz por todos os objetos a fim de deixá-los secando durante a noite. Assim chegava o fim do dia e como já estava escuro retornei para casa. Cabe aqui mencionar que ser mulher e atravessar a cidade do Rio de Janeiro a noite não é algo agradável, portanto aproveitei a companhia de Sarah Alves e pegamos um táxi até o metrô São Cristóvão, próximo ao destino dela e viável para acessar o metrô que me levaria até em casa. 


\subsubsection{Treinando a observação participante}

Entre o primeiro e segundo dia de atividade da $2^{\underline{a}}$ Rodada de Cicloativismo da Maré me debrucei sobre o capítulo que leva o mesmo título que este tópico 'Treinando a observação participante' do antropólogo americano William Foote-Whyte (in Guimarães, 1975, p. 77-86). O texto narra o envolvimento de Foote-Whyte em uma colônia italiana em um bairro de Nova Iorque, nos Estados Unidos, e o uso da observação participante junto aos sujeitos de sua pesquisa.

Foi interessante notar como os questionamentos de Foote-Whyte, datados da década de 1930, eram totalmente condizentes aos meus, uma designer experimentando a observação participante no processo de pesquisa. Quando perguntar informações? O que não dizer? Como interagir? Certamente não há fórmulas restritas para realizar o exercício da observação participante, mas sem dúvidas o autor me forneceu algumas ideias pertinentes. Entre elas pairava a minha constante inquietação em compreender rapidamente os projetos e as atividades desempenhadas por Lino e outros atores, porém sem incomodá-los com perguntas incessantes. Uma passagem do antropólogo ${ }^{149}$ foi esclarecedora com relação a esta dificuldade:

Na medida em que sentei e ouvi, obtive respostas para perguntas que nem teria feito se tivesse obtendo informações somente através de entrevistas. Naturalmente, não abandonei de todo as perguntas. Aprendi apenas avaliar a susceptibilidade da pergunta e o meu relacionamento com as pessoas de modo que só fazia perguntas em uma área sensível quando estava seguro e que meu relacionamento com a pessoa era sólido.

No intuito de ampliar a minha capacidade de escuta, no dia seguinte, percorri o mesmo trajeto até o Centro de Artes, mais uma vez preparada para continuar a minha participação nas atividades do evento. Neste dia, os integrantes do Muda Maré começaram a tomar decisões sobre fazer um buraco no chão para plantar uma árvore, enquanto outros participantes faziam marcas na parede para prender os pallets de madeira.

Notei que os participantes - entre integrantes do Muda Maré, jovens moradores da Maré e Lopes - temiam cometer erros na execução da atividade porque desconheciam técnicas de marcenaria, ao mesmo tempo, isto não os impedia de experimentar 
e realizar o processo do seu próprio modo, em que um auxiliava o outro. Embora fosse sempre estimulada a executar uma ação propositiva, fosse na universidade ou no mercado de trabalho, procurei apenas participar do processo e ajudar, seguindo o grupo Muda Maré que orientava a atividade.

Vi-me frente a um desafio, pois a todo o momento me vinha em mente a fala do Professor Dr. Heitor Frúgoli, do Grupo de Estudos em Antropologia da Cidade (GEAC) da Faculdade de Filosofia, Letras e Ciências Humanas da USP: "fiquem atentos para não realizar participação observante, que é bem diferente da observação participante"150. As palavras de Frúgoli rondavam meu pensamento, pois pela primeira vez eu me colocava em uma posição de observadora que participava, e só dava opinião quando fosse requerido, ao invés de tomar atitudes que ultrapassassem este limite. Preocupava-me em observar tudo que fosse possível e, ao mesmo tempo, participar, embora não fosse viável parar e ficar registrando em meu caderno de campo as situações vivenciadas ou falas escutadas ao vivo.

Este momento foi crucial, pois abri mão do registro etnográfico rigoroso, proposto por Malinowski (in Castro, 2016), para adotar uma prática de observação participante, na qual me deixei levar pela ação com as pessoas naquele tempo e espaço. Assim, a observação participante utilizada nestes encontros iniciais foi apoiada naquela descrita por Ingold (2013, p. 1-15), que sugere que a prática deve ir além da técnica de coleta de dados e que a base para compreender o contexto está no fazer. Esta postura requer que a prática seja transformadora, permitindo que o conhecimento venha de dentro, de forma que a investigação ocorresse em práticas de correspondência (Gatt; Ingold in Gunn et al., 2013) entre mim, pesquisadora, e as pessoas envolvidas naquele lugar.

Outro ponto que notei era que a cada diálogo e troca com as pessoas, mais eu me afetava com aquele espaço e mais ele me proporcionava aprendizados e vivências que eram transformadoras. Tratava-se de um espaço com problemas diários complexos, em que ações pequenas, como a proposta por Lino junto ao Muda Maré, representava um gesto político de mudança, resistência e amor ao lugar. Com a liberdade de "afe- 


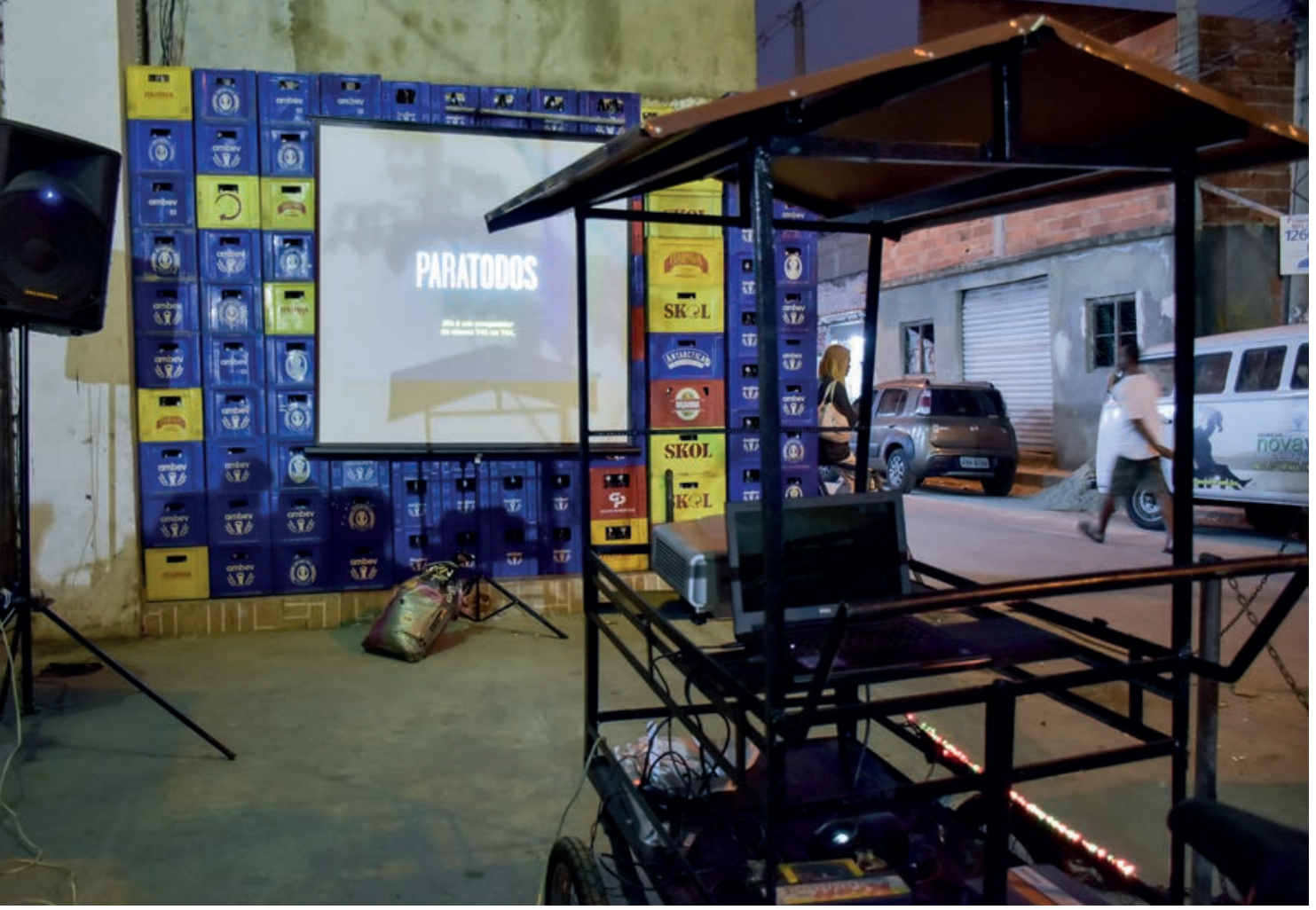

Figura 18: estrutura de telão montada na área externa em frente ao CAM. Fonte: fotógrafo Douglas Lopes, 2016.

tar-me em campo", pude trabalhar a minha sensibilidade com relação a questões mais profundas como sentimentos de diferença social e econômica e as relações hierárquicas a fim de encontrar uma relação de empatia e alteridade entre mim e eles.

A ideia de afetar e ser afetado pode ser vista no trabalho da antropóloga Jeanne Favret-Saada (1990), que durante sua pesquisa sobre feitiçaria em Bocage, na França, entrou em um embate: caso participasse, seu trabalho de campo se tornaria "uma aventura pessoal". Caso ficasse a distância, apenas observando, não acharia nada para "observar". Para tanto, encontrou um caminho para lidar com tal questão sem prejudicar a atividade em campo, por meio da tentativa de "fazer da 'participação' um instrumento de conhecimento"'151.

Deste modo, segui aprendendo com eles de forma que marcássemos os pontos em que os pallets seriam presos na parede e o buraco no chão fosse feito. Após as atividades manuais relativas à construção do jardim vertical estarem completas naquele dia, já que ainda seria preciso trazer terra e plantas que seriam colocadas no suporte de pallet, Lino come- 
çou a organizar a atividade que fecharia o dia de evento, a exibição de um filme partindo do projetor acoplado no triciclo multimídia produzido no evento anterior (figura 18).

\subsubsection{Táticas e técnicas do corpo na Maré}

Na sequência do evento, uma das integrantes do Muda Maré se prontificava para buscar crianças da Nova Maré para que estas participassem da sessão de cinema ao ar livre. Uma vez que a Nova Maré fica a certa distância do CAM, já com a chave do seu carro em suas mãos, ela lançou a pergunta: "Douglas, posso ir lá? Tá tranquilo? Tá favorável?"152. Foi interessante notar nesta pergunta que a integrante do grupo, já atuante há mais de dois anos e conhecedora do território da Maré e a complexidade de suas fronteiras, buscou entender a situação no interior da favela naquele momento por meio de uma música famosa de funk do cantor Mc Bin Laden, amplamente conhecida na Maré, para se informar diante de um assunto intrincado e difícil ${ }^{153}$.

Os gestos e desdobramentos na linguagem são muito comuns no território, o uso constante de termos do funk, estilo musical predominante nas favelas cariocas, são amplamente apropriados pelos moradores e frequentadores como recursos de discurso. Compreender que a linguagem popular da favela ia além de uma forma de se comunicar, mas uma forma de subverter o cotidiano complexo, me evidenciou como as táticas (De Certeau, 2014) eram inerentes na fala, na ação e no corpo das pessoas.

Este aspecto foi compreendido também através da leitura do antropólogo Marcel Mauss (2003, p. 407) e seu capítulo sobre as técnicas do corpo, no qual aborda sobre os diferentes modos de agir, em que a técnica é entendida como "um ato tradicional e eficaz", transmitida entre os seres humanos. Ao lidarmos com as técnicas do corpo, Mauss ${ }^{154}$ coloca que "o corpo é o primeiro e o mais natural instrumento do homem, (...) mais natural objeto técnico".

152. Dizeres de uma integrante do Muda Maré no dia 16 de setembro de 2016 no âmbito da 2a Rodada de Cicloativismo, realizada Centro de Artes da Maré, Rio de Janeiro.

153. Música 'Ta Tranquilo Ta Favorável' de MC Bin Laden. Videoclipe oficial do cantor. Disponível em: <https://www.youtube.com/watch?v=vkJ5LcoWwVw>. Acesso em: 5 de Jan. 2016.

154. Ibid., p. 407 
Ao retornar com as crianças, que tinham entre cinco e dez anos de idade, para a exibição do filme, notei que mesmo as pequenas já faziam o uso de gírias típicas da favela usadas por mais velhos, tal como "é o bonde", ao se referir a um grupo de pessoas, ou o termo "novinha" para se referir a qualquer menina, ainda que desconhecida. Com técnicas corporais completamente diversas das crianças da Zona Sul do Rio de Janeiro, espaço que cresci e vivi a minha infância, ficava evidente a colocação de Mauss ${ }^{155}$ sobre "os fatos de educação" predominarem, visto que uma vez que as crianças ali recebem uma educação similar, isto é, todas estudam na Maré e frequentam espaços da Redes da Maré diariamente , é possível "compreender a sequência dos encadeamentos" na transmissão das técnicas, ora na fala, ora nos gestos. Podemos extrair do texto do autor ${ }^{156}$ uma colocação que se encaixa perfeitamente ao que me refiro:

O que se passa é uma imitação prestigiosa. A criança, como o adulto, imita atos bem-sucedidos que ela viu ser efetuados por pessoas nas quais confia e que têm autoridade sobre ela. $O$ ato se impõe de fora, do alto, assimila a série dos movimentos que é composto o ato executado diante dele ou com ele pelos outros.

Outra situação interessante observada foi com relação ao modo como as crianças e jovens manuseavam objetos ao seu redor. Um exemplo é o modo como as crianças conseguiam pedalar bicicletas bem maiores que o seu tamanho com facilidade e agilidade, já que são habituadas desde pequenas a andar em qualquer uma. Esse aspecto retorna para os conceitos de táticas, apenas citado, e estratégias de De Certeau (2014, p. 91), já que a forma como dominavam os materiais e buscavam maneiras rápidas de encaixe, ainda que fossem movimentos errados, mostrava como a sua ação não se apoiava em um planejamento, ou manual de montagem, mas à improvisação e às formas inventadas no momento para resolver o objeto.

Aprendendo a ler as técnicas do corpo locais e identificar táticas cotidianas, continuei minha participação junto a todos, montando o espaço e preparando-o para a exibição do filme. O vídeo exibido tratava-se de uma compilação audiovisual de outros projetos e atividades em que as crianças apareciam e podiam se reconhecer neles. Entre os

155. Ibid., p. 405.

156. Mauss, op. cit.., p. 405 

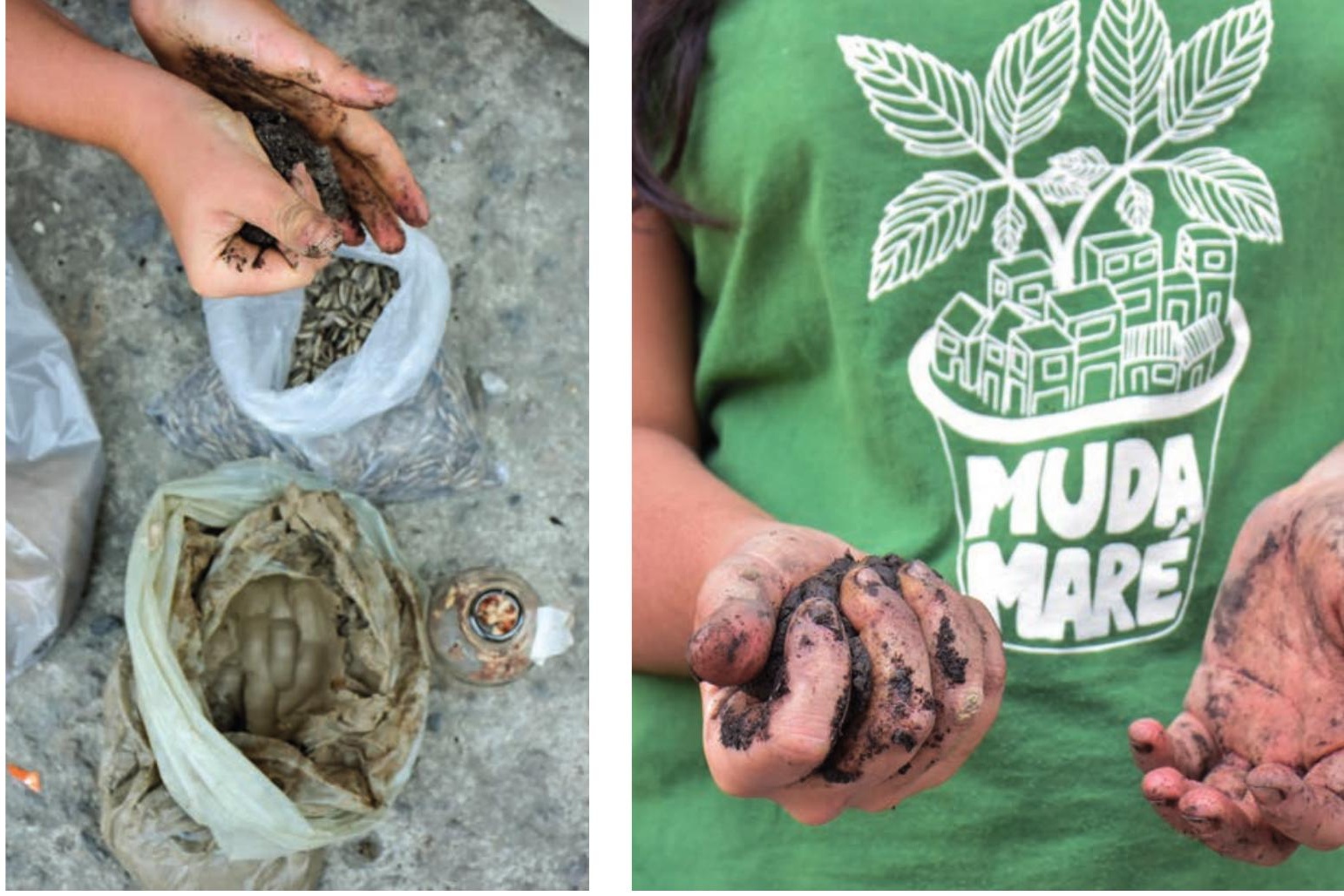

Figura 21: Produção das bombas de sementes. Fonte: fotógrafo Douglas Lopes, 2016.

Após terminarmos o jardim vertical e deixarmos as bombas de sementes preparadas, partimos para a última atividade de todo o evento: um passeio ciclístico que saía do CAM até o Parque Ecológico da Maré. Pegamos bicicletas que estavam estacionadas no bicicletário no interior do CAM e saímos em direção ao espaço (figura 22). Depois de vinte minutos pedalando, chegamos ao espaço, similar a um parque, localizado em uma altitude maior, onde é possível observar quase toda a Maré e a Ilha do Fundão. Lá, as bombas de sementes foram arremeçadas para que crescessem no futuro (figura 23), um ato simbólico de cuidado com a Maré, construído coletivamente.

Finalizamos a atividade e retornamos para o CAM e, na sequência, fomos todos almoçar no Bar da Amparo, restaurante da mãe de Douglas Lopes, pernambucana e moradora da Maré há mais de quarenta anos. Neste encontro, diversos atores da Redes da Maré vieram e assim concluímos o evento da 2a Rodada de Cicloativismo na Maré. 
ções me auxiliaram na identificação das vocações comunitárias, como sugerido por Richard Sennett (2013b), para a abordagem de desafios do cotidiano na Maré por meio de ações de arte e cultura em todo o território.

No intuito de não perder o fôlego acerca das narrativas no território, esta percepção será profundamente explorada no capítulo quatro, em que estabeleço pontes entre as vivências reais e algumas concepções teóricas que auxiliaram na compreensão dos fatos observados ${ }^{160}$. Estas concepções teóricas são: os 'rituais de cooperação' e o 'aprendizado colaborativo', de Richard Sennett (2013a; 2013b), as 'táticas', de Michel De Certeau (2014) e as 'formas de improvisação', abordadas por Tim Ingold e Elizabeth Hallam (2007).

Além disso, estas vivências me fizeram compreender que para realizar processos colaborativos utilizando as abordagens que selecionei, seria imprescindível mergulhar no território, conhecê-lo e entender as suas complexidades com uma maior profundidade, visto que apenas em visitas ocasionais seria inviável. Em razão disso, parti para segunda fase do processo a fim de mergulhar no território e no âmbito das redes da Maré, tal qual narro no próximo tópico.

\subsection{Imersão no Complexo da Maré: reconhecendo o território}

Após o período de visitas ocasionais, notei que embora eu tivesse uma série de aportes teóricos e referenciais em mãos, existia a necessidade de realizar uma imersão mais profunda no âmbito da Redes da Maré, a fim de compreender melhor seu cotidiano, as relações entre atores e as práticas realizadas a partir da minha própria perspectiva. Conversei com Lino pelo telefone em meados do mês de janeiro de 2017 e combinamos que eu frequentaria a Maré no mês de março, sempre nos períodos da tarde e da noite, de modo que eu conseguisse usar o período da manhã para registrar os acontecimentos vivenciados.

160. As relações entre estas concepções teóricas e as vivências em campo foram já abordadas no artigo 'Design by means of citizen activism: three cases illustrated by the action of Coletivo Maré, Rio de Janeiro, Brazil', desenvolvido por mim e com coautoria de Marcos Rosa e Maria Cecilia Loschiavo dos Santos para a 12th European Academy of Design - Design for Next, apresentado em abril de 2017 na Faculdade de Arquitetura Valle Giulia, Universidade Sapienza, em Roma, Itália, com apoio da FAPESP e do Programa de Apoio à Pós-Graduação da CAPES (PROAP). 
Embora houvesse muitos espaços permanentes para investigar - Lona Cultural Herbert Vianna, CAM, Sede da Redes da Maré, Casa das Mulheres e outros -, devido à parceria estabelecida com Lino, optei por focar apenas naqueles que ela era responsável, ou seja, a Lona Cultural e o CAM. Carreguei comigo todas as observações anteriores e concepções teóricas levantadas até aquele momento e, desta vez, realizei a observação participante com maior frequência e por um período mais longo.

\subsubsection{Configuração de uma rotina de pesquisa no território}

Retornei à Maré no dia três de março de 2017, uma sexta-feira pós carnaval, chegando por volta das duas horas da tarde por meio do mesmo trajeto de sempre, que foi repetido até o inicio de abril: casa, metrô, Cidade Nova, parador e CAM. Combinei com Lopes de encontrá-lo na Lona Cultural no período da tarde, onde aconteceriam as atividades do Projeto Nenhum a Menos, enquanto no CAM não aconteceriam atividades até as dezenove horas e não estaria ninguém por lá, exceto funcionários que ficam na recepção.

Como de praxe, cheguei à rua do CAM e me apresentei novamente aos funcionários que lá estavam, pois sabia que eles passariam a me ver com frequência. Assim, conheci melhor Marcos, que trabalha na equipe de produção cultural e no balcão de entrada fornecendo informações, e Maurício, que é responsável por limpar, organizar e fazer a manutenção do espaço. Perguntei qual o melhor modo de chegar à Lona Cultural sem moto-taxi e Marcos me sugeriu pedalar com uma das bicicletas do CAM, do mesmo modelo que eu havia utilizado durante as visitas ocasionais. No entanto, optei pelo moto-taxi, pois ainda não me sentia confortável para ir sozinha pedalando até a Lona, especialmente por conta da temerosa fronteira na altura da Rua Ivanildo Alves.

Subi na moto e o motociclista estava especialmente desconfortável em me levar até o local, visto que alguns dias antes havia ocorrido uma complexa operação policial contra uma das facções criminosas locais e o clima de tensão ainda pairava no ar. De todo modo, fui levada até o localpor uma tarifa de cinco reais, valor superior à passagem de ônibus tradicional da cidade do Rio de Janeiro, que na época custava $R \$ 3,60$, evidenciando que eu deveria buscar outros trajetos ou meios menos custosos para me 
deslocar. Neste momento, surgia em mim a inevitável questão que eu precisaria trabalhar se quisesse de fato me engajar com o território: conquistar a minha autonomia.

Cheguei à Lona e agora conheceria novos atores. O primeiro, Paulinho, morador da Maré, religioso, funcionário da Redes da Maré há muitos anos, é responsável pela limpeza e organização do espaço, além de abrir e fechar os portões da Lona de segunda a sexta-feira das nove horas da manhã até as seis horas e trinta minutos da tarde. Atencioso, me avisou que Lopes ainda estava em horário de almoço e me levou até Marra, que planejava a atividade de dança com salto, o Stiletto, que ocorreria na Lona em alguns dias. Cumprimentamos-nos e ele me levou até a biblioteca que fica dentro dos muros que cercam a Lona Cultural, oficialmente cunhada de Biblioteca Popular da Maré Jorge Amado. Lá, conheci Mariane Rodrigues, que atuava como bibliotecária e também auxiliava na organização das atividades com as crianças.

Rodrigues nasceu e cresceu na Maré, realizava o curso de História da Arte na UFRJ e trabalhava na Lona há poucos meses. Recém-mudada da Nova Holanda para outra parte da Maré por conta da continuidade de confrontos, Rodrigues me contou o quanto amava viver na Nova Holanda devido a grande quantidade de serviços oferecidos - comércios, bares, restaurantes, bailes e outros - fosse dia ou noite, além da grande circulação de pessoas, destacando-se em relação à vivacidade das outras favelas.

Na sequência, conheci Luanna Sena, uma jovem estudante da Maré que iniciara seu trabalho na Lona no início de 2017, auxiliando nas atividades do Projeto Nenhum a Menos. Quando cheguei, Sena coordenava várias crianças durante uma atividade de robótica, na qual elas construíam robôs e automóveis e aprendiam sobre o assunto. Fiquei por um tempo observando as crianças que, embora nunca tivessem me visto antes, já me tratavam como conhecida e me solicitavam para separar brigas ou brincar com elas.

O Projeto Nenhum a Menos ${ }^{161}$ foi iniciado em 2014 com a coordenação da pedagoga Inês Salles, dando sequência ao antigo "Programa Criança Petrobras na Maré" (Redes da Maré, 2018). Hoje, o projeto visa auxiliar crianças de seis a oito anos em atividades 
diárias entre as três e as quatro da tarde e de nove a doze anos em atividades diárias entre as quatro e meia às cinco e meia da tarde. O projeto nasceu a partir da necessidade de providenciar a reinserção escolar de crianças, de modo que fossem devidamente alfabetizadas, mas tomou uma grande magnitude, tornando-se um importante vetor na complementação pedagógica.

De acordo com a página web da Redes da Maré162, o projeto foca "no reforço do vínculo entre alunos, família e escola (...), inclui melhoria da aprendizagem formal, valorização do ambiente escolar e também apoio de assistência social às famílias. (...) Na Lona, meninas e meninos fazem oficinas diárias de letramento, música e robótica" além do "contato estreito com os familiares, através de reuniões presenciais com assistentes sociais ou mesmo visitas às casas. Há ainda um lanche todos os dias, preparado pela equipe do projeto Maré de Sabores", projeto de gastronomia liderado por mulheres da Maré e sediado na Casa das Mulheres no Parque União.

Acompanhei a atividade de robótica e conheci também o professor de música e educador Roberto França, atuante na organização desde a era CEASM, que ainda hoje dá aulas de música e outras atividades como dança e jogos para crianças semanalmente. Além dele, conheci nos dias subsequentes Dayana Sabani, professora e educadora da Redes da Maré, ex-moradora da Maré e atuante no projeto há alguns anos em aulas no espaço da biblioteca que envolvem desenhos, vídeos e mapas que engajam as crianças. Seu trabalho é realizado com o suporte de Sena e de Rodrigues, que também organizam o lanche das crianças, dado pontualmente ao final do horário das duas aulas - às quatro horas da tarde e às cinco e meia da tarde.

Neste ínterim, Lopes havia chegado do almoço e estava no camarim, área ao lado da biblioteca usada como escritório e reservada para artistas nos casos em que a Lona é utilizada para concertos e apresentações de teatro, música e dança. Fiquei acompanhando seu trabalho que focava em realizar algumas peças gráficas para o cortejo do grupo Tambores de Olokun, que ocorreria no dia dezoito de março na Maré, e conversamos sobre design gráfico, assunto de seu grande interesse de aprendizado. 
Neste dia, Lopes me contou que o conflito ocorrido anteriormente havia ocupado toda a fronteira entre a Nova Holanda e a Nova Maré, de maneira que seria impossível sair dali para qualquer lugar, obrigando crianças, professores e colaboradores que estavam no dia a ficarem dentro da biblioteca até quase nove horas da noite. Esta circunstância afastava a vinda de crianças para atividades e impedia que houvesse aulas nas escolas próximas, tornando as condições de trabalho no local ainda mais difíceis, não apenas pelo risco em que os colaboradores eram expostos, mas também devido a interrupção do trabalho com as crianças, que perdiam o ritmo e a disciplina a cada vez que passavam o dia sem poder ir para a escola ou para a Lona.

Ao terminar o dia, voltei caminhando com Lopes pela Rua Ivanildo Alves, que me acompanhou até a passarela oito, onde eu atravessaria e pegaria o ônibus de volta para casa. No caminho, conversei com ele sobre a minha dificuldade de me deslocar no território por ainda ter medo de andar sozinha, especialmente por ser de fora da Maré e foi interessante como ele mesmo foi totalmente aberto a minha questão dizendo: "fique tranquila, mesmo eu que cresci aqui também fico inseguro de andar em alguns lugares às vezes, mas em breve você vai se encontrar”'163 (comunicação oral).

Este seria um dia comum durante o período acompanhando os trabalhos de Lino, Lopes e outros atores da Redes da Maré, aos quais fui me aproximando a cada dia que eu acompanhava as atividades, sempre muito generosos e cuidadosos com o seu trabalho. Assim, minha rotina diária seguiria esta configuração: de casa até o CAM, do CAM até a Lona, observação das atividades durante a tarde, esticando para algumas atividades à noite no CAM em alguns dias específicos - cinema, roda de debate, shows, aulas de ballet infantil, dança, teatro ou outra atividade cultural - ou então retornando para casa.

Em poucas exceções passei o dia no CAM, como quando ocorreu uma reunião de discussão sobre o espaço e pude acompanhar as principais questões mencionadas no próximo tópico sobre os espaços investigados. Além disso, participei e acompanhei outras atividades fora desta rotina, como as atividades para crianças do Muda Maré para o Projeto Nenhum a Menos, que ocorre às sextas-feiras, as aulas de percussão do 
professor Rodrigo Maré, músico, ativista cultural e morador do território, que ocorre aos sábados, o evento Favela Rock, concerto mensal de bandas de estilo musical rock na Lona Cultural, organizado por Lino e a equipe, e outras atividades no período da noite no CAM, envolvendo shows, projeções e encontros.

A rotina foi também estabelecida por conta da minha ausência de autonomia, que me impedia desde o início caminhar livre pelo território a fim de conhecê-lo com maior facilidade. Desde o início, eu sabia que precisaria conquistar essa autonomia para me deslocar sozinha e, felizmente, uma série de acontecimentos foi favorável a isso, fosse por meio do meu contato com pessoas da Redes da Maré, fatores externos ou a partir da minha própria disposição. Inicialmente, eu optava por descer do ônibus na altura do CAM, visto que ficava a poucos metros da Avenida Brasil, o que era um problema nas vezes em que eu deveria ir direto para a Lona Culturalpara acompanhar as atividades que ocorreriam por lá. No entanto, ficava apreensiva em descer sozinha em outro ponto de ônibus que eu não conhecesse e por isso recorria ao CAM e ao moto-taxi. Neste sentido, narro no tópico a seguir não apenas como conquistei a minha independência e autonomia de deslocamento, mas como isso modificou completamente a minha percepção sobre a Maré.

\subsubsection{Adentrando espaços e a busca por autonomia}

Terça-feira, dia sete de março de 2017, saí de casa e fui para a Maré. Era o quarto dia que eu ia para o local e ainda não sabia muito bem como andar sozinha em seu interior. Ao chegar ao CAM encontrei Lino sentada em uma mesa no fundo conversando com Iury Lobo, colaborador da Redes da Maré. Cumprimentamos-nos e ela disse: "está rolando uma atividade muito legal aqui, acho que você deveria participar" (comunicação oral). Entrei na roda com outras pessoas e entre elas estavam Mariane Rodrigues, bibliotecária da Lona, Luana Sena, assistente das atividades na Lona, Roberto França, professor de música, e Inês Salles, coordenadora do projeto Nenhum a Menos, que liderava a atividade.

A atividade consistia em uma roda de música em pares, na qual aprendemos uma coreografia para depois ensiná-la às crianças do Nenhum a Menos. Uma vez que 


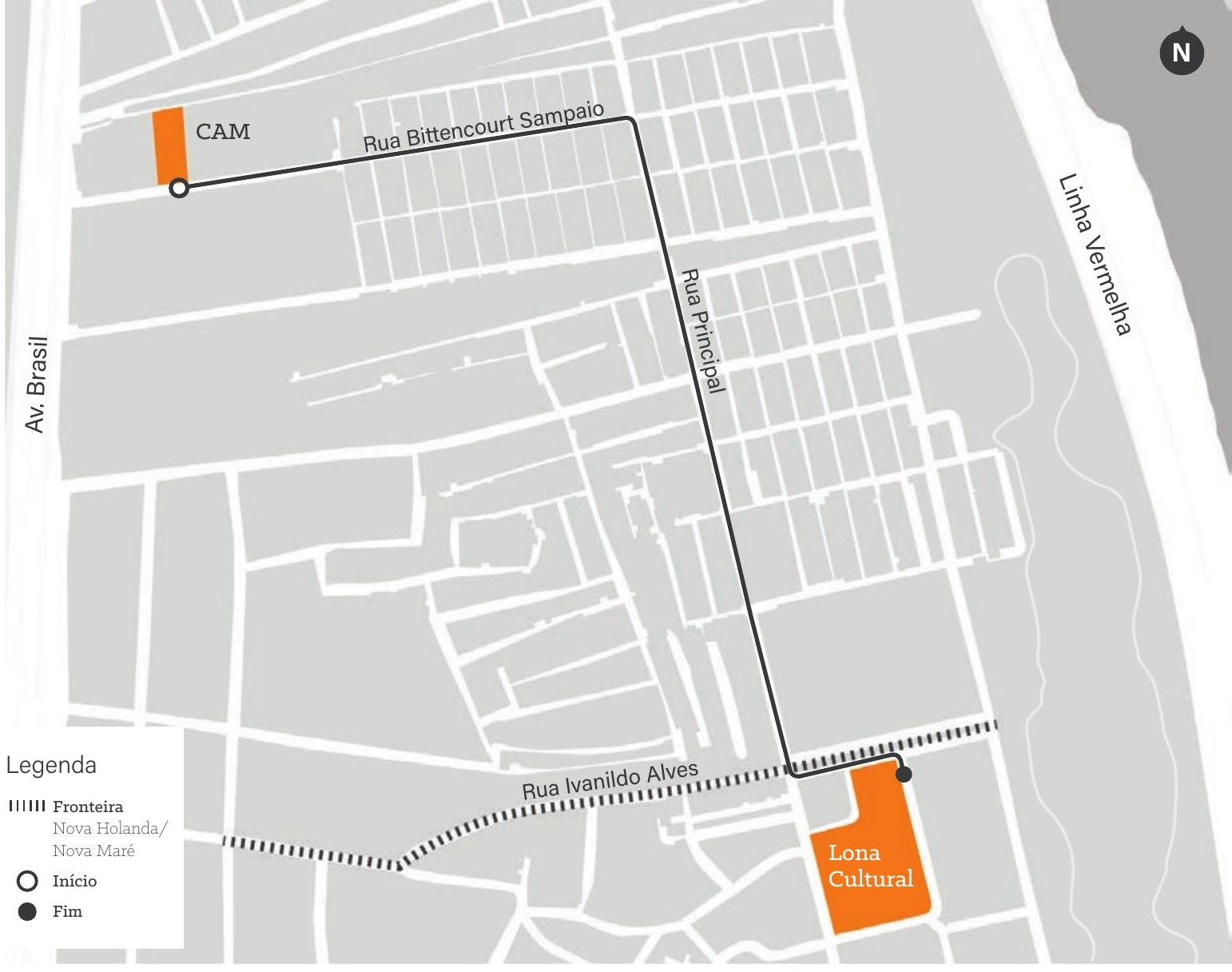

Figura 24: trajeto que parte do CAM até a Lona Cultural. Fonte: elaborado pela autora, 2018.

todos compreenderam a dança, o grupo que a praticava se reuniu no intuito de ir caminhando em direção a Lona Cultural para as atividades da tarde com as crianças. Imediatamente, peguei as minhas coisas e pedi para acompanhá-los na caminhada para que eu aproveitasse a companhia, também com a intenção de realizar o trajeto a pé, que até o momento eu só havia conseguido realizar de moto-taxi.

Parti com os quatro para a Lona e fui conversando com Rodrigues, que me contou que sempre se perdia quando caminhava na Nova Holanda (área de localização do CAM) durante o período que viveu por lá. No caminho, fomos conversando e fui observando cada passo, desde o momento em que viramos à direita na Rua Principal até o momento em que entrarmos à esquerda na Rua Ivanildo Alves, como evidenciado no mapa (figura 24). Percebi o quão simples era o trajeto, mas que ainda assim era temeroso para muitos em virtude da fronteira na altura do valão.

Rodrigues contou que a atenção e a informação eram pontos cruciais para se deslocar no território e que com exceção aos confrontos, a vida comunitária na Maré possuía 
um sentido da vida diferente dos bairros fora da favela, fosse devido à relação mais humana entre as pessoas ou a sua energia cultural pulsante. Assim, sugeriu-me que o acesso com maior sensação de segurança vindo da Avenida Brasil em direção a Lona seria por meio da Rua Teixeira Ribeiro, que fica em frente a passarela nove e possui muitos comércios. Em sua proposta, eu seguiria da Av. Brasil até a Rua Principal e caminhando por apenas duas retas, chegaria a Lona Cultural.

Foi interessante escutar de Rodrigues e Sena que desde pequenas eram aconselhadas a não transitar pelo Complexo da Maré, fazendo com que elas e outras diversas mulheres se deslocassem menos no território, fato que foi também confirmado por Lino após acompanhar a pesquisa sobre mobilidade na Maré pelo Data Labe (2018). Chegando próximo a Lona, as duas apontaram para uma casa, localizada na esquina da Rua Ivanildo Alves com a Rua Principal, marcada por buracos de tiros e relataram sobre a tensão com relação aos confrontos no local.

Desta maneira, perguntei como poderia me informar antes de atravessar aquela área e elas me sugeriram ficar atenta a uma página do Facebook chamada "Maré Vive"164, que informa diariamente como está a situação de segurança na Maré, ou enviar uma mensagem de celular perguntando a elas ou a Lopes sobre a situação. Após esta ocasião, comecei a experimentar outros trajetos e observar o que era possível fazer caminhando sem depender de um moto-taxi ou uma companhia.

No dia seguinte, resolvi seguir a sugestão de Rodrigues (figura 25) e olhei na página do 'Maré Vive', na qual não constavam confrontos. Desci no ponto de ônibus da passarela nove em frente à Rua Teixeira Ribeiro e fui caminhando pela calçada, margeando os comércios. A quantidade de pessoas na rua era imensa e havia serviços de todos os tipos abertos entre mercados, lojas, mercearias, açougues com galinhas engaioladas, serviço de dentista, casas de material de construção e por aí em diante. Cheguei até a Rua Principal e tudo corria bem, parecia um dia comum, sem confrontos e sem problemas a vista, até chegar próximo à área de fronteira, a qual eu atravessaria sozinha pela primeira vez. Vazia, com vários homens armados imponentemente ou com rádios 


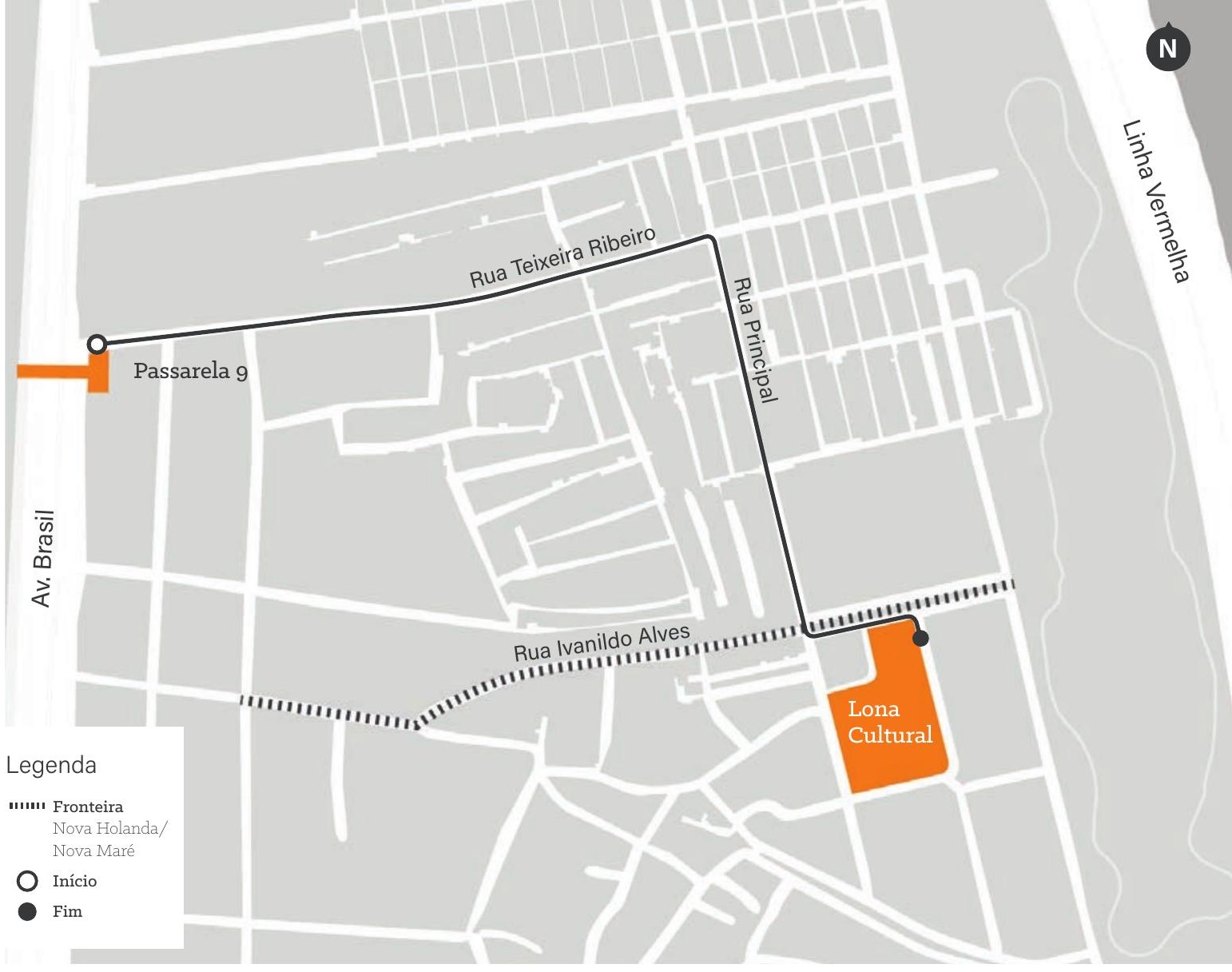

Figura 25: trajeto que parte da passarela nove (Rua Teixeira Ribeiro) até a Lona Cultural. Fonte: elaborado pela autora, 2018.

acoplados na cintura, segui caminhando olhando para baixo, até virar na Ivanildo Alves e chegar à Lona Cultural.

Ao chegar, encontrei com Marra, Lopes e Rodrigues e fui contar a minha nova conquista: chegar à Lona sozinha sem precisar de ajuda. Comemoramos e Marra comentou: "eu entendo como você se sente, eu mesmo que moro aqui na Nova Holanda, 150 metros daqui, tenho estado com muito medo, principalmente por causa dos tiros do último confronto. Atravessei até a minha casa e foram cinco minutos que pareciam uma hora caminhando"’165 (comunicação oral). Compreendi a situação e notei que o único jeito era caminhar cada vez mais pelo território, sempre atenta, até que eu conseguisse conhecê-lo melhor e alcançasse a minha autonomia. 
Com o passar dos dias fui me sentindo mais confiante para caminhar até a Lona, fosse partindo do CAM ou da Rua Teixeira Ribeiro. Em um determinado momento, passado uma semana da primeira vez que caminhei sozinha, desci no ponto de ônibus do CAM com o intuito de passar no local e conversar com Lino, que não estava presente. Deste modo, conversei com Marcos Diniz, que se encontrava no local e me sugeriu ir de bicicleta até a Lona, visto que seria muito mais rápido. A partir desta ocasião, passei a fazer o trajeto com o transporte, evitando caminhar pela fronteira, mas passando rapidamente por ela pedalando. Neste mesmo dia, após acompanhar as atividades na Lona Cultural, retornei pedalando com Lopes até o CAM, pois acompanharíamos outra atividade que ocorreria durante a noite, e fizemos um novo caminho por uma rua paralela atrás da Rua Principal. Ali aprendi um novo caminho, o qual adotaria em momentos em que a fronteira estivesse em clima de tensão ou simplesmente para evitar passar pela confusão da Rua Principal.

Nos dias subsequentes, Lopes foi me ensinando outros caminhos para chegar à Lona - por meio de trajetos a partir da passarela oito, nove ou a partir do ponto de ônibus da Bittencourt Sampaio - ou para sair da Lona - por meio da Rua Principal até as ruas Teixeira Ribeiro ou Bittencourt Sampaio, seguindo reto na Ivanildo Alves até chegar na Avenida Brasil ou seguindo a Rua Principal à esquerda e cruzando a Baixa do Sapateiro até a Rua Flávia Farnese, paralela a Avenida Brasil (figura 26). Pouco a pouco, passei a transitar entre a Nova Holanda, Nova Maré, Baixa do Sapateiro e Parque Maré me sentindo segura mesmo completamente sozinha, ponto de extrema relevância no processo. Embora fosse algo comum e fácil para quem é proveniente da Maré ou frequentador do seu cotidiano, para mim representava uma vitória para o desenvolvimento da pesquisa.

É válido mencionar que algumas outras situações vividas também me auxiliaram a conquistar a minha autonomia, como o dia em que fui com Sena buscar os lanches das crianças até a Casa das Mulheres, no Parque União. Desta vez, atravessamos o caminho juntas e no trajeto ela foi me mostrando cada uma das ruas transversais, incluindo a rua da Sede da Redes da Maré. Em outra vez, fui com Rodrigues até um escritório da Redes da Maré para pegarmos um documento e ela me mostrou a Praça da Nova Holanda e a quadra do Gato, famosa por desfiles no carnaval e pelos seus 
frequentes bailes funk $k^{166}$. Outro exemplo foi quando voltei a pé durante a noite na companhia de um dos jovens frequentadores da Lona e fomos pela Baixa do Sapateiro até a Avenida Brasil. Além dessas, tiveram as vezes que fui com Lopes até o Bar da Amparo pedalando pela Rua Flávia Farnese e ele me mostrou outras áreas, incluindo a área do Pexinchete, mercado e padaria próximos a Teixeira Ribeiro, e a Rua Tatajuba, onde frequentemente ocorriam confrontos. Ademais, fatores como clima, usualmente de sol e calor, o constante acesso a página do 'Maré Vive' antes de ir para a Maré e o uso da bicicleta foram imprescindíveis para aprender a me deslocar de forma independente, com segurança e agilidade no território.

Foi interessante notar como a minha percepção sobre a Maré foi modificada: de um lugar no qual me sentia com medo, insegura e preocupada em andar sozinha, passei a me sentir segura e certa dos locais em que estava, incluindo nos períodos em que não havia mais luz do dia. Quanto mais eu conhecia a Maré, menor a minha preocupação e maior a minha percepção acerca de sua potência, vivacidade e pluralidade, ao passo que passei, muitas vezes, a me sentir mais segura lá dentro do que fora, na 'cidade formal'. A autonomia me trouxe muitos benefícios, incluindo a minha capacidade em observar com maior precisão os detalhes do território, os arredores dos espaços que frequentei e os espaços em si, com suas qualidades e complexidades, como mostro no próximo tópico.

\subsubsection{A Lona Cultural Herbert Vianna}

Como situado anteriormente acerca da minha rotina de investigação, ao me orientar pelos passos de Lino e Lopes acabei direcionando o meu olhar para dois espaços específicos: a Lona Cultural Herbert Vianna e o Centro de Artes da Maré. Ao longo do

166. O baile funk é uma tradição nas favelas cariocas. Especificamente no Complexo da Maré, a pesquisadora Eliana Sousa e Silva (2015, p. 53) coloca que "a proibição dos bailes funk, a partir da segunda metade da década de 1990, gerou grave impacto na favela da Maré: em primeiro lugar, a decisão destruiu uma atividade econômica que gerava empregos, renda e prestígio social para milhares de jovens das favelas e periferias. Além disso, a criminalização do gênero musical fez com que principalmente os grupos ligados ao tráfico de drogas dominassem os bailes. Esse processo contribuiu para o fortalecimento do 'proibidão' - gênero da música funk dominado por letras que fazem apologia ao tráfico de drogas -, para o aumento da discriminação dos jovens adeptos do estilo, para o aumento das situações de violência e de confronto entre os traficantes e a polícia - que tenta proibir o baile -, além de dificultar a prática cotidiana de uma importante atividade de lazer dos moradores das favelas". 


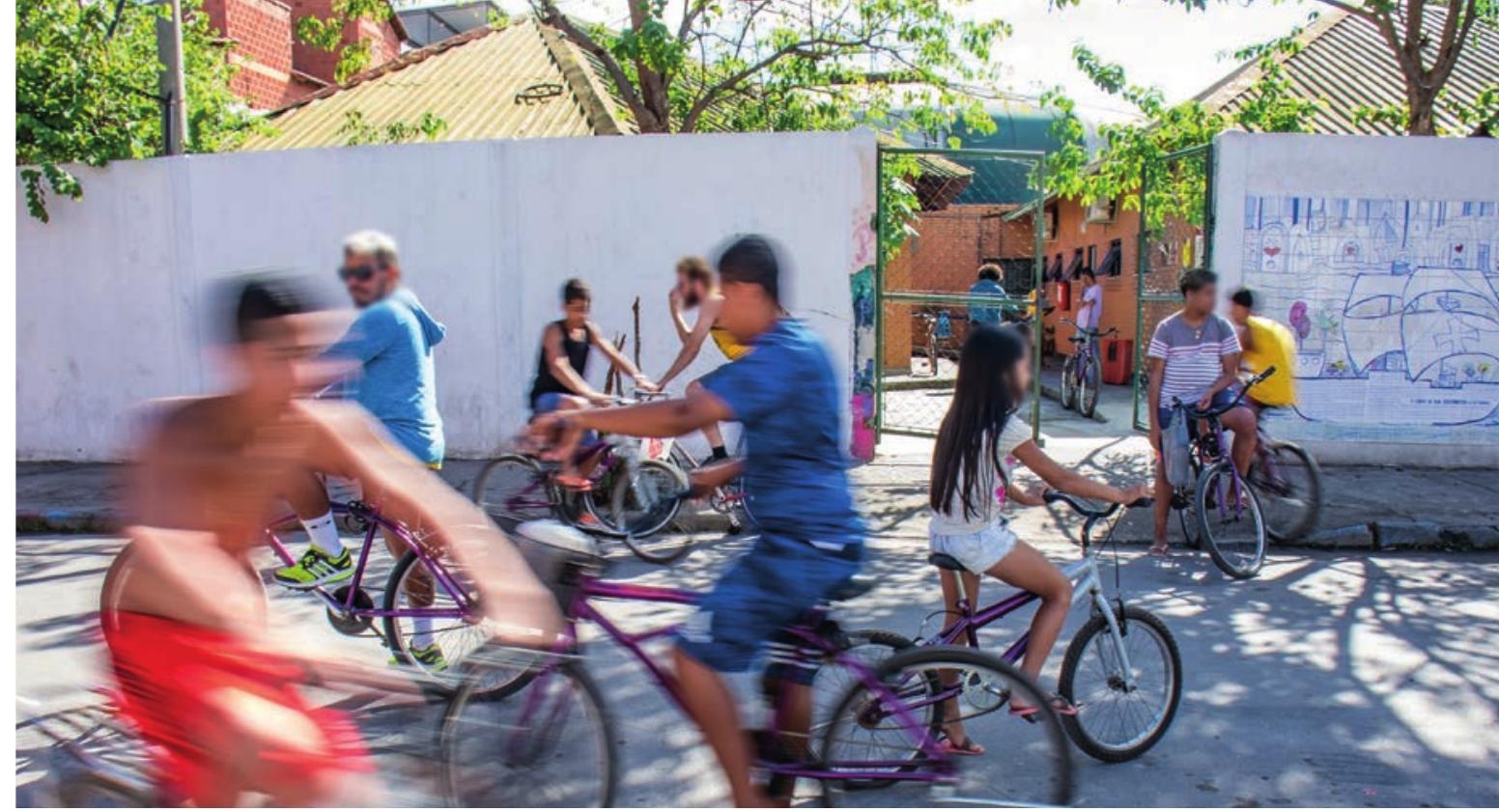

Figura 27: entrada da Lona Cultural Herbert Vianna na Rua C. Fonte: autora da dissertação, 2017.

período de imersão foi possível participar de muitas experiências nesses espaços e em seus arredores e levantar impressões relevantes que me auxiliassem a compreender as questões de interesse ${ }^{167}$ existentes.

O primeiro espaço está localizado na Rua Ivanildo Alves s/n, na entrada da favela Nova Maré, ou Tijolinho, como é popularmente chamada (figura 27). Construída no local pela Prefeitura do Rio durante o mandato do ex-prefeito César Maia, foi inaugurada em 2005 e tinha como objetivo abrigar eventos de cultura, como shows, apresentações de teatro, dança e música. Em 2009, a Redes da Maré optou por assumir a cogestão do espaço, a fim de realizar "um projeto de intervenção cultural contínuo em um território marcado por conflitos entre grupos criminosos armados"168 (Redes da Maré, 2018).

Lino conta que de tempos em tempos a Redes da Maré é responsável por aplicar para o edital de cogestão do espaço, ainda que eles façam trabalhos de base no local há quase dez anos. Atualmente, o espaço é uma referência para produção cultural, espe-

167. A ideia de questão de interesse é aqui baseada no conceito discutido por Bruno Latour (2009) acerca das questões de fato e questões de interesse (originalmente na língua inglesa como matters of fact e matters of concern). $\bigcirc$ conceito foi associado a demandas locais dos parceiros, no entanto no capítulo quatro me debruço sobre reflexões teóricas entrelaçadas em vivências de campo a fim de elucidar a apropriação do conceito na pesquisa.

168. Descrição da Lona Cultural Herbert Vianna. Página sobre o espaço no site da Redes da Maré. Disponível em: <http://redesdamare.org.br/blog/uncategorized/lona-cultural-herbert-vianna-promovendo-encontros-e-rompendo-fronteiras-2/>. Acesso em: 28 de Jul. 2017. 


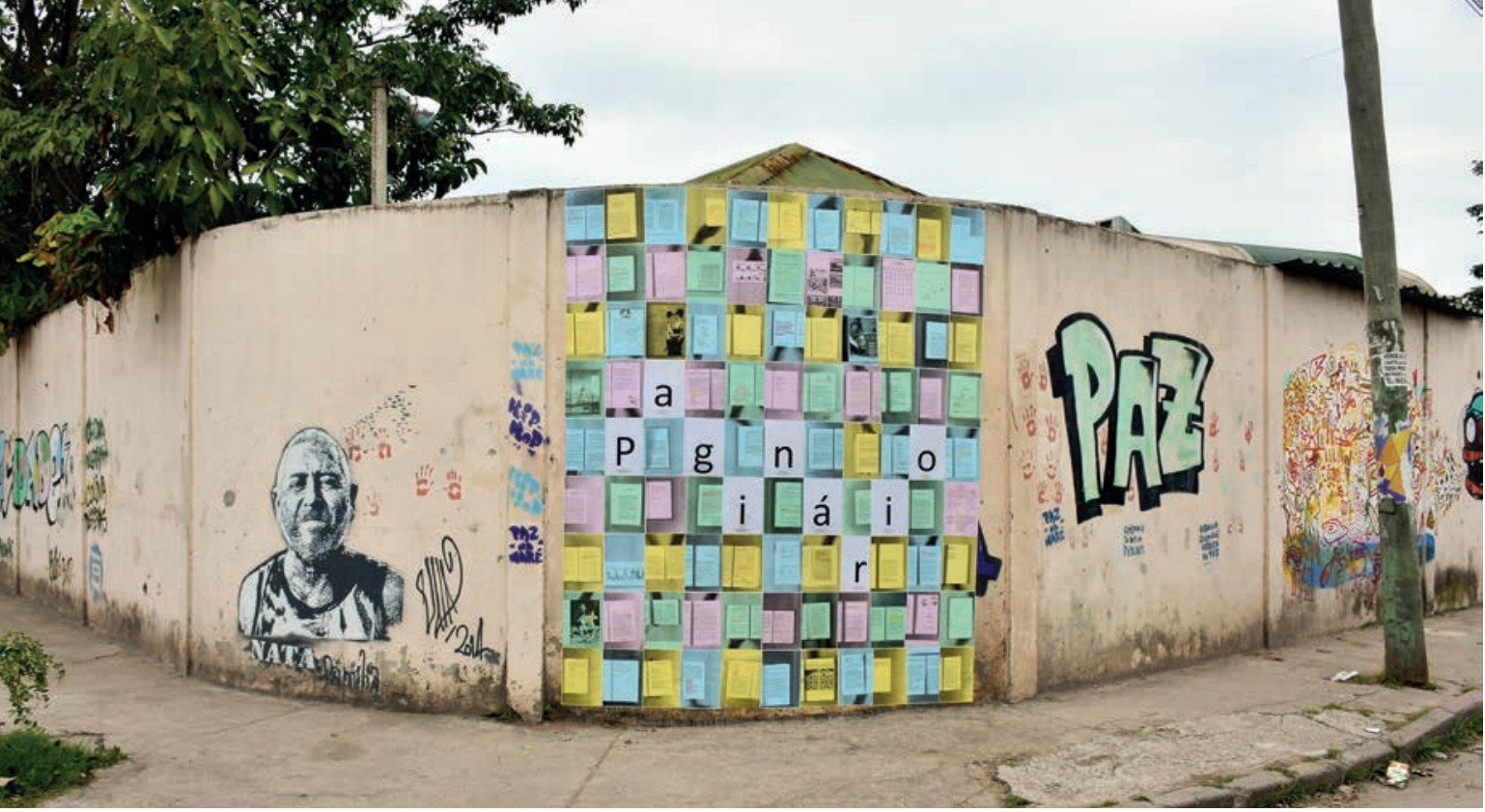

Figura 28: intervenções nos muros da Lona Cultural. Fonte: fotógrafo Douglas Lopes, 2014.
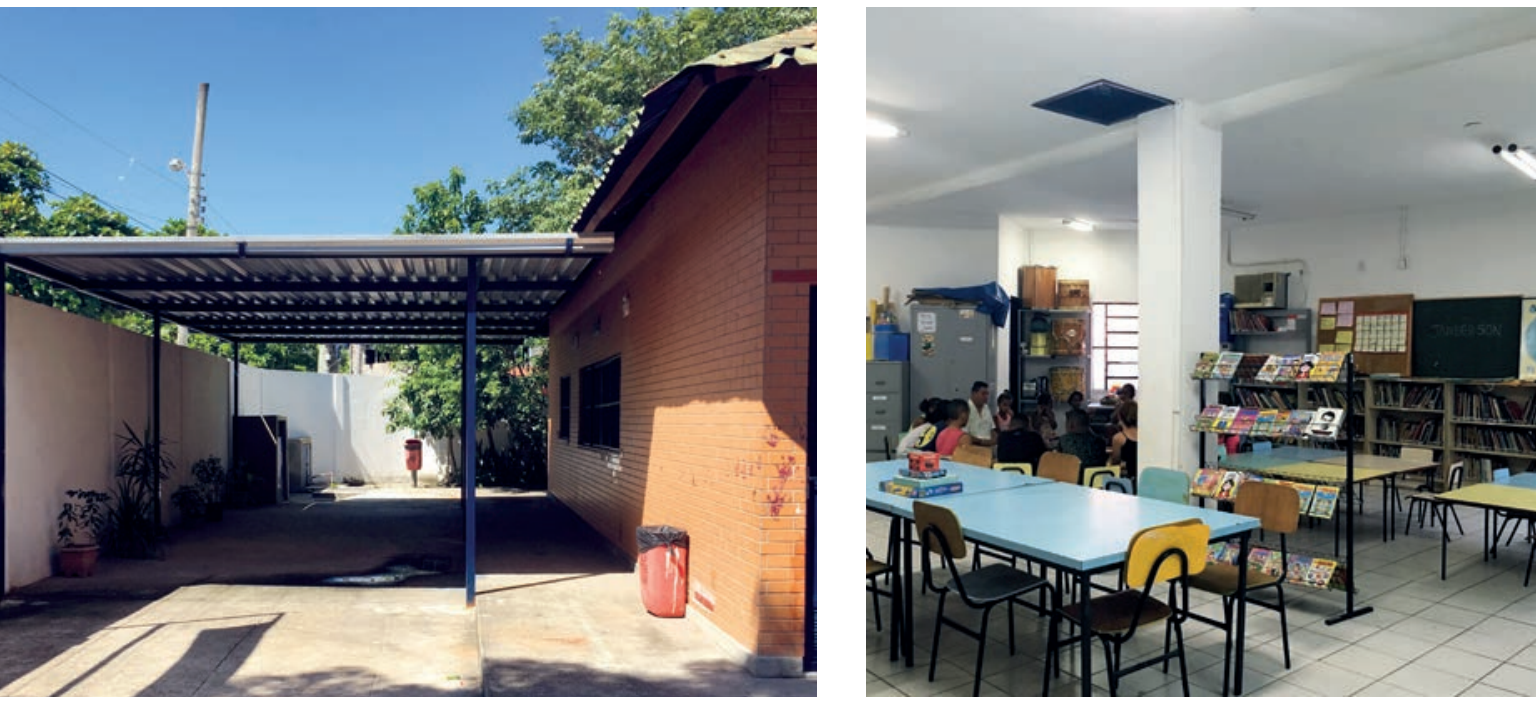

Figuras 29 e 30: interior dos muros da Lona Cultural Herbert Vianna (29) e interior da Biblioteca Municipal Jorge Amado (30). Fonte: autora da dissertação, 2017.

cialmente no âmbito musical, visto que recebe muitos espetáculos e atrações por meio de uma programação diversificada, coordenada e organizada por Lino, que coordena o espaço desde 2013. O espaço é rodeado por muros que já receberam diversas intervenções (figura 28), como grafites, colagens, estêncil, entre outras, e possui duas entradas: uma na Rua Ivanildo Alves, a oficial, e outra na Rua C, em frente à rua da Nova Maré. 
Dentro do espaço há três infraestruturas cobertas: a Biblioteca Municipal Jorge Amado, uma casa com a mesma arquitetura que a biblioteca e a própria lona cultural (figura 29). No interior da biblioteca há uma série de estantes de livros de vários tipos, desde ficções e romances a livros de geografia, história e didáticos. Há diversas mesas e cadeiras para crianças, jogos e brinquedos, um mapa mundi e um varal de trabalhos infantis (figura 30).

No interior da casa ao lado da biblioteca, há a cozinha que conta com diversos aparatos para suportar eventos, como refrigeradores, geladeiras, balcão e outros, uma sala anexa em que guardam bicicletas ou realizam atividades de cineclube, um pequeno escritório onde Marra trabalha, o camarim com espelhos e iluminação própria, além do escritório em que Lopes costuma trabalhar. Já a lona possui uma estrutura de aço coberta com um resistente material de lona sintética, verde e branca, e em seu interior há um palco e uma arquibancada que recebem manutenção semanal. Ainda dentro dos muros do local há uma série de espaços abertos que são usados para diversas atividades, como aulas de pandeiro, colônia de férias infantil, espaço para socialização em dias de concertos e reuniões da Redes da Maré.

\subsubsection{Vivências na programação da Lona Cultural}

Durante meu período acompanhando o trabalho na Lona pude perceber como o espaço é multifuncional e abriga diferentes modalidades de ocupação, ora focadas em educação, arte e cultura infantil, ora focadas em produção cultural para moradores da Maré. Alguns momentos de convívio se destacaram, como a semana do dia internacional da mulher, em que acompanhei as aulas da professora Dayana Sabani. Nesta aula, as crianças assistiram um vídeo da Malala ${ }^{169}$, a fim de discutir os direitos de educação da mulher, e realizaram uma atividade de escrita, na qual elas escreviam em balões de fala recortados como vencem o machismo no dia-a-dia (figura 31).

169. Malala Yousafzai é uma ativista paquistanesa que luta pelos direitos de meninas do mundo todo, principalmente relativos à educação. Ela ficou conhecida ao redor do mundo depois de sofrer um ataque do Talibã no caminho da escola por causa de seus esforços a favor da educação de meninas no seu país. Seus esforços contínuos a tornaram a pessoa mais jovem ao receber o prêmio Nobel. 
Um ponto relevante ao acompanhar esta aula específica foi quando a professora explicou o contexto de guerra em que Malala estava inserida e uma das crianças se identificou com o caso e disse: "é como os tiros que tem aqui, tia?"170 (comunicação oral). Por meio do projeto Nenhum a Menos, fosse através das aulas de música, jogos ou aulas temáticas (figura 32) como a citada, foi possível compreender melhor como aquele contexto afetava diretamente a formação das crianças em seu comportamento, nas relações interpessoais e, principalmente, nas referências cotidianas.

Outro aspecto relevante é o amor que era colocado por cada uma daquelas pessoas envolvidas no projeto Nenhum a Menos, tanto na relação com as crianças quanto no cuidado com o espaço e na transmissão da proposta da Redes da Maré para o território. Um exemplo percebido foi um cartaz colocado na biblioteca em que as crianças narram a história de Eliana Sousa e Silva e sua luta de resistência no território, o que também me ajudou muito a entender melhor a história da própria Redes da Maré.

Além disso, vale ressaltar as sextas-feiras em que estive no lugar, visto que pude acompanhar aulas de música no período vespertino junto ao professor Roberto França, em que desenvolvemos ao longo do mês a construção de um chocalho de materiais reciclados que fazia barulho de chuva, e acompanhei algumas aulas de educação ambiental semanais do grupo Muda Maré. Este último tem um papel chave no projeto Nenhum a Menos, visto que os integrantes trazem para as crianças, por meio de diversos suportes visuais, temáticas ambientais que envolvem o cuidado com o espaço público e o despejo de resíduos, a pluralidade sobre a biodiversidade brasileira e a formação infantil acerca de uma vida mais sustentável no cotidiano, influenciando diretamente as crianças.

Na segunda sexta-feira em que estive presente, presenciei o evento Favela Rock, coordenado por Lino e sua equipe. O evento é gratuito e ocorre mensalmente no período da noite e recebe de uma a três bandas de estilo rock. Segundo Lino, há um público ampliado que se interessa e procura esses eventos somente realizados na Lona Cultural, como mencionou Lino: "Você acha que na Maré as pessoas só escutam pagode, forró e 

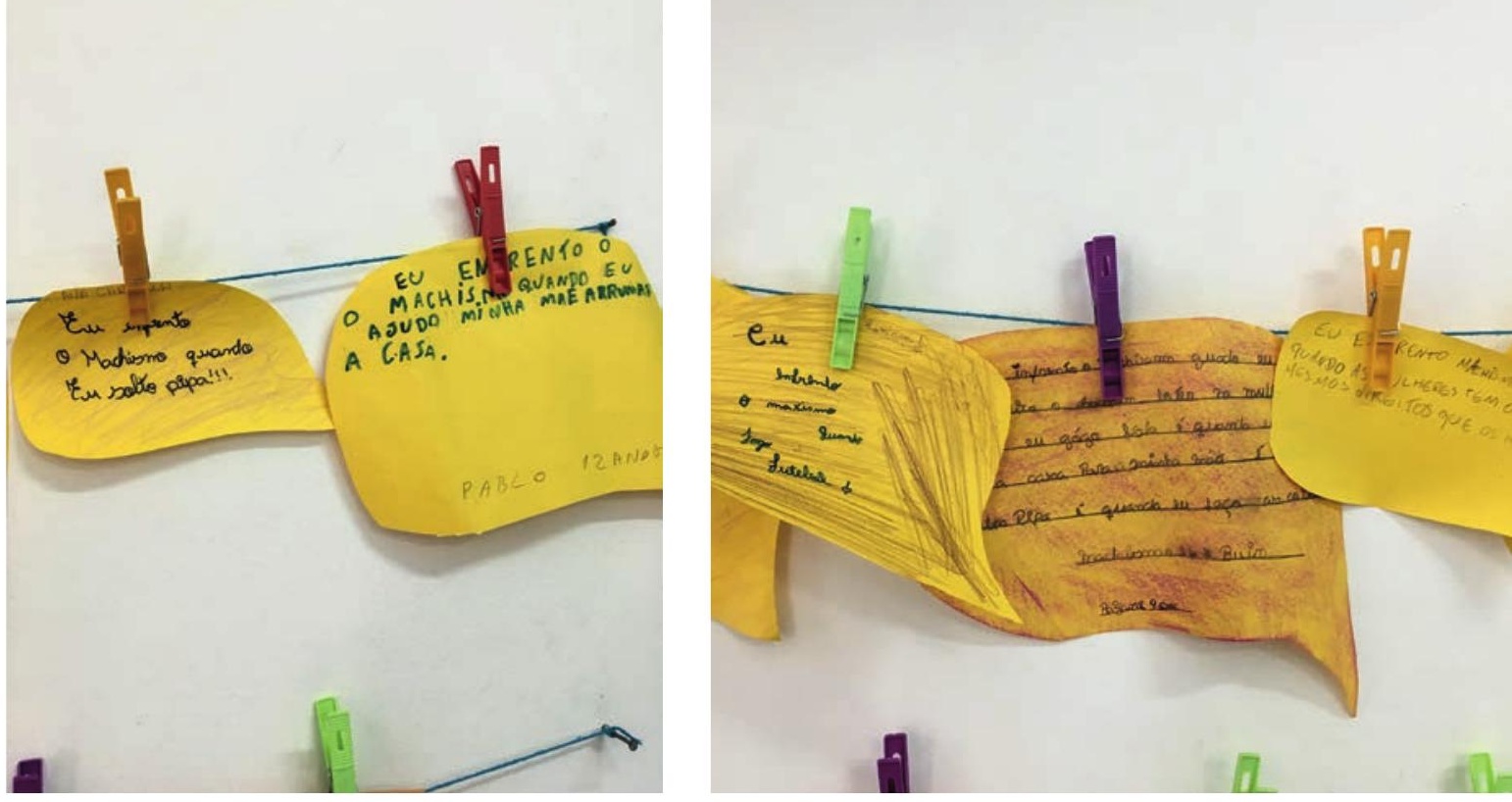

Figura 31: varal de trabalhos infantis. Fonte: fotógrafo Douglas Lopes, 2017.

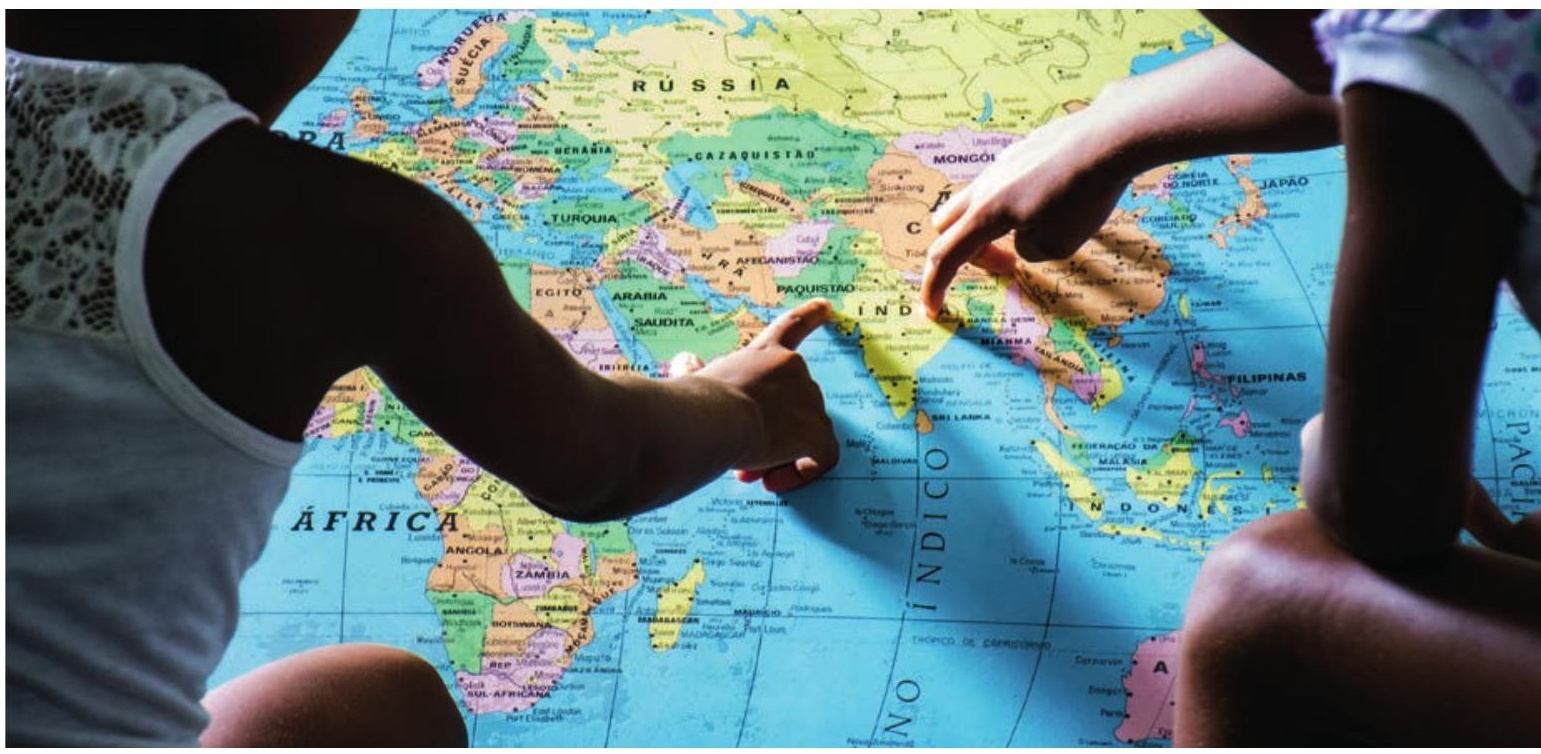

Figuras 32: aula sobre a Malala no dia internacional da mulher. Fonte: fotógrafo Douglas Lopes, 2017.

funk? Aqui tem milhares de roqueiros e metaleiros, hoje você verá pela quantidade de pessoas vestindo preto durante o show, isso aqui fica lotado!"171 (comunicação oral).

171. Dizeres de Geisa Lino no dia 10 de março de 2017 na Lona Cultural Herbert Vianna, Complexo da Maré, Rio de Janeiro. 
Durante a produção do evento fiquei observando como transformavam o espaço de cunho educacional para um espaço de festa e evento cultural, com a montagem de um bar, a estruturação de iluminação dentro da lona e toda organização espacial. Além disso, tive a oportunidade de conversar melhor com Alberto Aleixo, com quem havia encontrado pouco até o momento e que neste momento havia apenas iniciado a posição de Diretor da Redes da Maré. Aleixo é também um ator central na Redes da Maré, visto sua articulação e dedicação ao território desde a sua juventude. Ele me contou de todo o trabalho que tiveram para ocupar a Lona ao compartilhar a gestão com a Prefeitura do Rio de Janeiro, seu abandono e descuido, além de inúmeras promessas de manutenção não cumpridas e as negociações com grupos armados que dificultaram ainda mais todo o processo de ocupação do espaço. Neste dia fiquei na Lona até às 22 horas e pude interagir com várias pessoas da Maré envolvidas na sua plural produção cultural. Após este horário, precisei retornar, visto que seria um pouco inseguro voltar sozinha pela Avenida Brasil durante a noite.

Outra vivência relevante durante o período em que estive presente na Lona foi o desenvolvimento de um mural de estêncil junto a Lopes. Ainda no início do meu período de imersão, Lino, Lopes e outros participantes me apontaram o interesse em refazer o estêncil de uma parede na entrada da Lona Cultural, de forma que me pediram sugestões sobre o que poderia ser feito. Vi esta oportunidade como um caminho para a realização de uma atividade propositiva, ainda que breve, com os parceiros de pesquisa.

Com o intuito de levantar questões de interesse coletivamente e levando em conta o conhecimento do grupo na técnica de estêncil, trabalhada diversas vezes com o coletivo Nata Família ${ }^{172}$, sugeri que fizéssemos um mural como o da artista americana Candy Chang ${ }^{173}$. Em 2011, Chang desenvolveu um mural que continha a frase "Antes de morrer eu...", que deveria ser completada em giz por pessoas que passassem e quisessem interagir com o muro. A mesma ideia foi também adotada em diversos outros

172. Coletivo Nata Família. Página oficial do grupo. Disponível em: <https://www.facebook.com/ NataFamilia>. Acesso em: 12. Mar. 2017.

173. Projeto "Before I Die" de Candy Chang desenvolvido desde 2011 em diversas cidades americanas. Página oficial do projeto. Disponível em: < http://candychang.com/work/before-i-die-in-nola/>. Acesso em: 12 Mar. 2017. 

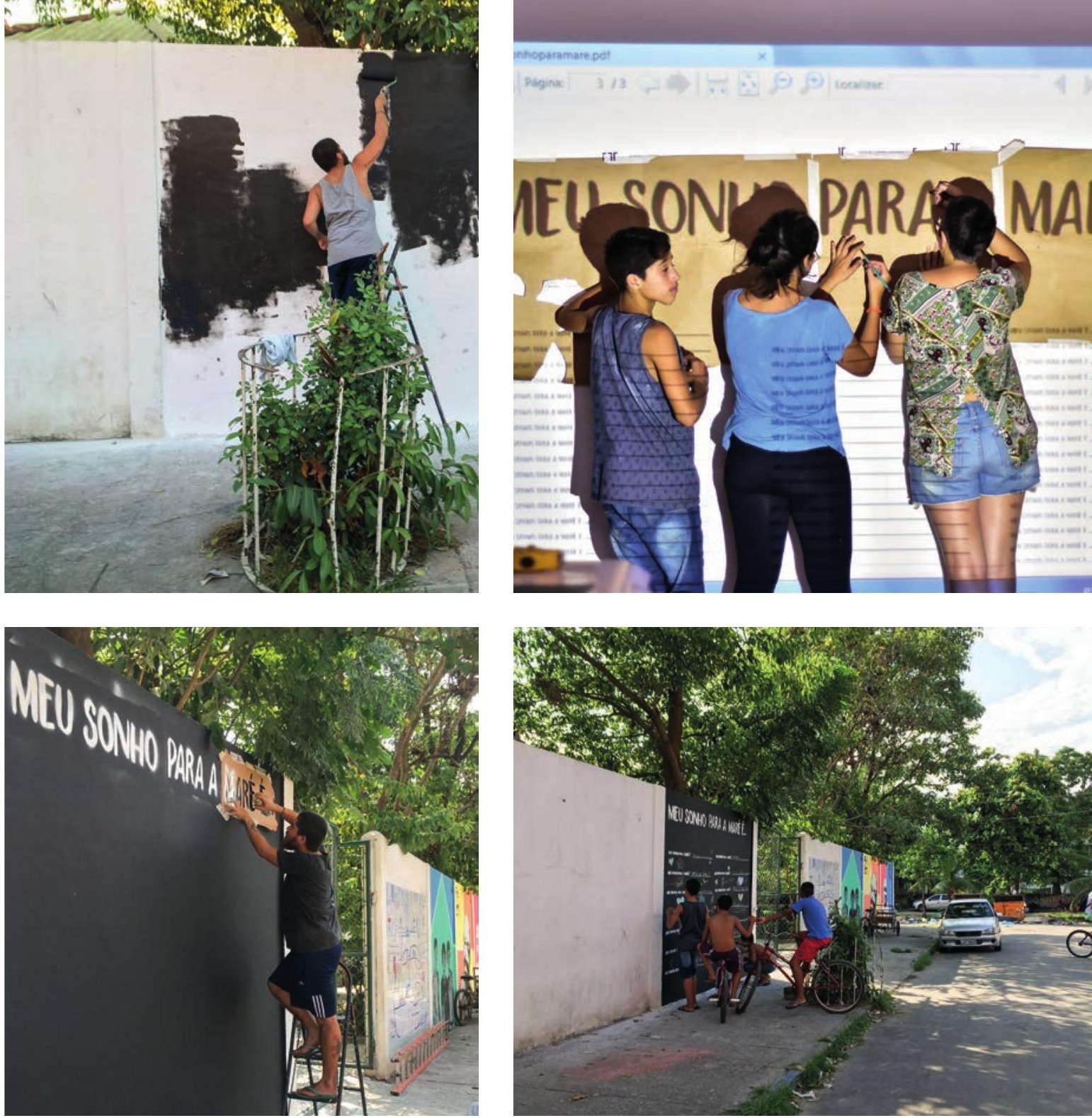

Figura 33: processo de montagem do muro 'Meu sonho para a Maré é...'

Fonte: autora da dissertação, 2017.

locais, incluindo o mural "Liberte seus sonhos"174, desenvolvido pelo coletivo carioca Muda em várias áreas da cidade, com destaque ao realizado no bairro da Lapa no Rio de Janeiro, também utilizado como referência.

Desta forma, propus que fizéssemos um mural semelhante, porém com a frase "Meu sonho para a Maré é..." de forma que crianças e jovens da Lona Cultural pudessem

174. Projeto 'Liberte seus sonhos'. Página oficial. Disponível em: <http://liberteseussonhos.art.br/>. Acesso em: 12 Mar. 2017. 


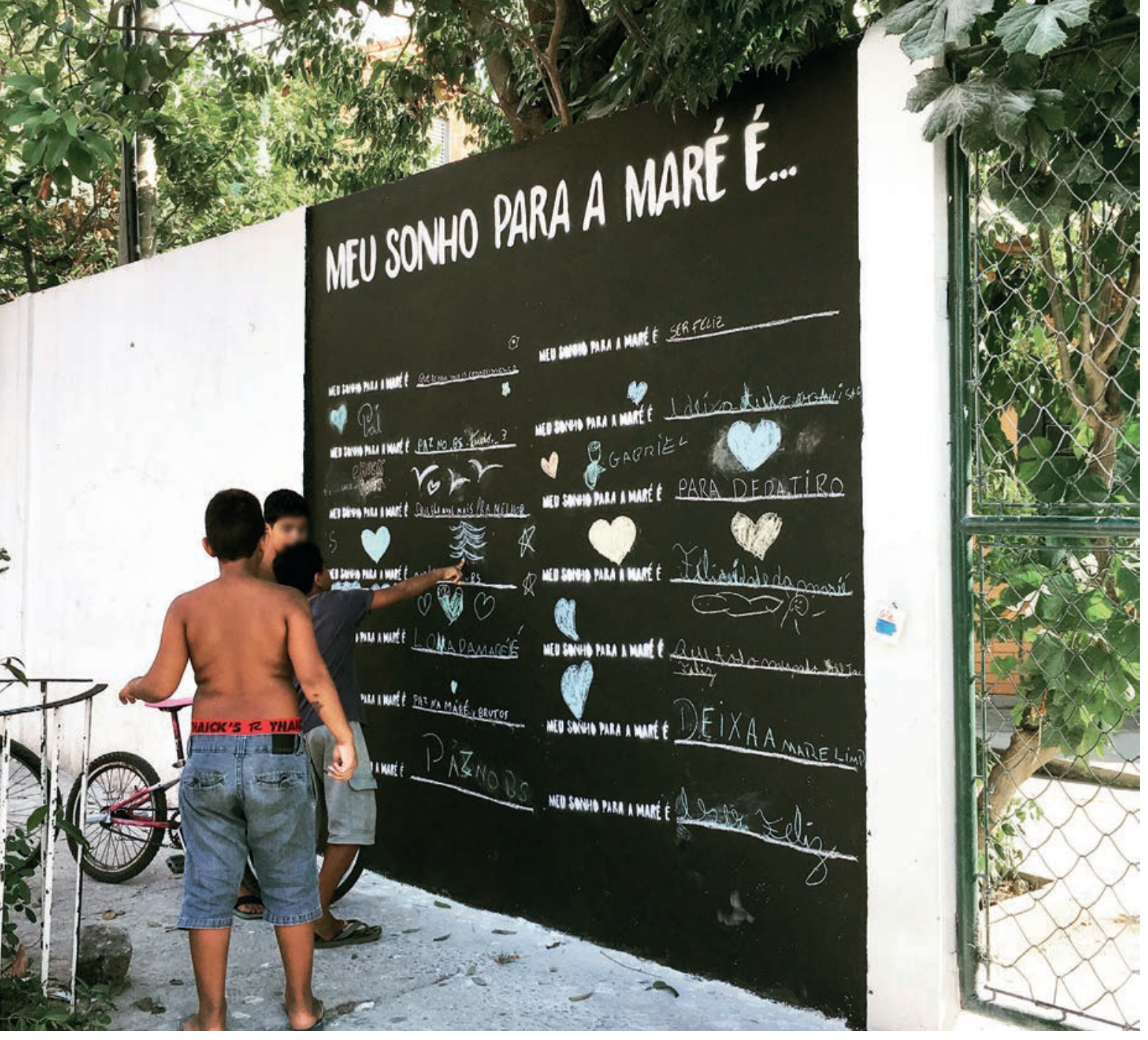

Figura 34: resultado final do muro 'Meu sonho para a Maré é....' Fonte: elaborado pela autora, 2018.

interagir e colocar suas esperanças e sonhos no muro do local. Percebi esta proposta como uma oportunidade para gerar diálogos sobre as questões cotidianas, além de percebê-las visualmente, visto que muitas vezes era difícil conversar sobre as demandas diárias. Assim, Lopes, Rodrigues e eu contamos com o apoio das crianças e juntos passamos massa na parede, lixamos e recortamos o estêncil, pintamos a parede e aplicamos a arte (figura 33).

Foi interessante notar que a troca com adultos, jovens e crianças da Nova Maré, mesmo durante o processo, foi extremamente rica e as questões levantadas por todos cercam vontades simples e ao mesmo tempo complexas, como a paz, o fim da violência e mais conhecimento para a Maré (figura 34). Ao mesmo tempo, uma série de sonhos e vontades simples, cotidianas, como mais piscinas na Nova Maré, mais brincadeiras 
na Lona Cultural e mais bicicletas. Esta atividade foi válida para compreender ainda melhor o espaço da Lona Cultural, suas potencialidades e como é um local de referência direta para todos ao seu redor.

\subsubsection{Centro de Artes da Maré}

Migrando para o Centro de Artes da Maré (figura 35), o outro espaço que acompanhei durante o período de imersão, pude notar como seu uso é bastante diversificado em relação ao realizado na Lona Cultural, não apenas pela modalidade de suas atividades, mas por conta de sua localização de fácil acesso, que permite uma visitação maior para quem vem de fora da Maré. É possível perceber que a frequência na Lona é majoritariamente de pessoas da própria Maré, enquanto no CAM há diversas pessoas tanto de dentro da Maré quanto de fora que vão ao local.

Localizado na Nova Holanda, na Rua Bittencourt Sampaio número 181, cerca de 150 metros da Avenida Brasil, o Centro de Artes é um espaço privado que foi adquirido pela Redes da Maré e transformado em ponto de cultura no território. A antiga fábrica de produção de copos e pratos de papel desativada foi transformada em um centro voltado para arte e cultura, oriundo da parceira da Redes da Maré com a Companhia de Dança Lia Rodrigues ${ }^{175}$, coordenado pela bailarina e coreógrafa homônima. De acordo com a página da Redes da Maré (2018)176, o espaço visa "à promoção do encontro de saberes entre a companhia, a comunidade e a instituição”. Além disso, “(...) passou por reformas e adaptações para as atividades de criação da Companhia de Dança, como oficinas de dança e expressão corporal abertas à comunidade", sendo "um espaço de circulação e produção de práticas que estimulem novas formas de apreensão do mundo. Nele são desenvolvidas expressões artísticas múltiplas, que permitam aos seus frequentadores usufruir e produzir linguagens que em geral são pouco acessíveis aos setores sociais populares".

175. Companhia de Dança Lia Rodrigues. Página oficial da companhia. Disponível em: <http://www. liarodrigues.com>. Acesso em 12 Ago. 2017.

176. Descrição do Centro de Artes da Maré. Página sobre o espaço no site da Redes da Maré. Disponível em: <http://redesdamare.org.br/blog/arte-e-cultura/centro-de-artes-da-mare/>. Acesso em: 28 de Jul. 2017. 
riais e objetos. Em seu interior (figura 36), sua parte esquerda conta com uma galeria de arte logo a sua entrada, um bicicletário em que ficam várias bicicletas da Redes da Maré, um balcão de recepção, um espaço vazio no meio com apenas uma mesa, seus instrumentos de música, livros e piano. Ao fundo, conta com cortinas pretas, utilizadas em espetáculos, uma arquibancada cinza feita de pallets de madeira pregados e uma plataforma utilizada para diversas aulas de dança, teatro e performance. Em seu depósito, também na parte esquerda, há diversos materiais e objetos, como impressos antigos, placas de madeira, calhas de metal e poltronas antigas de cinema doadas e nunca utilizadas.

Em seu lado direito, possui banheiros, um mapa antigo com todas as regiões da Maré e uma área livre e extensa com apenas uma enorme plataforma, na qual sucede a Escola Livre de Dança da Maré177, desempenhada também pela Companhia de Dança Lia Rodrigues. Interligando as duas partes do espaço há apenas dois corredores: um central e mais largo em que há uma copa com geladeira e pia para os usuários do espaço, outro apertado logo na entrada com apenas uma pia e uma mangueira.

Na entrada do CAM há uma larga calçada, uma exceção em relação ao resto da Rua Bittencourt Sampaio, em que ora estão veículos estacionados - carros, motocicletas e kombis -, ora a calçada está vazia, ora é ocupada com atividades como oficinas de conserto de bicicletas, projeção de filmes, encontros e debates etc. Do outro lado da rua há uma série de peças de veículos abandonadas, já em seu lado direito, no sentido de quem está de frente para o CAM, há caixas plásticas de cerveja formando uma parede ao lado de um bar, enquanto em seu lado esquerdo há o galpão Bela Maré, um centro de arte coordenado pelo Observatório de Favelas, parceiro da Redes da Maré. 
O Bela Maré, embora vizinho ao CAM, é um espaço distinto que recebe exposições de arte, como o Travessias ${ }^{178}$, anualmente realizado pela produtora Automatica ${ }^{179}$, lançamentos de livros, seminários e exibição de filmes. Em seu primeiro andar, o espaço conta com uma larga estante desenvolvida pelo escritório de arquitetura RUA Arquitetos ${ }^{180}$, uma área de oficina e outras pequenas salas. No segundo andar há uma extensa maquete do Complexo da Maré181, que já viajou para duas exposições de arquitetura internacionais, a Bienal de Veneza na Itália e a Bienal de Arquitetura de Chicago nos EUA, e foi desenvolvida por meio de oficinas colaborativas de arquitetura entre o mesmo escritório citado e moradores da Maré.

O CAM é coordenado por Geisa Lino desde o início de 2017 e conta com uma equipe de colaboradores que atua em várias frentes, desde o cuidado com o espaço até a sua produção cultural. Suas inúmeras atividades vão além de aulas de dança e performance, abarcando também encontros, rodas, debates, apresentações e espetáculos. Sua programação é contínua e já recebeu muitos artistas para concertos, debates de candidatos à eleição, lançamento de livros, além de ser um espaço para confraternizações da organização.

\subsubsection{Vivências na programação do Centro de Artes da Maré}

Durante o período que acompanhei o espaço pude vivenciá-lo principalmente nos momentos em que o convívio era mais exacerbado, como o período da tarde e da noi-

178. O Travessias é um evento desenvolvido anualmente pelo Observatório de Favelas junto a produtora de eventos Automática, contando com o apoio da Redes da Maré e o escritório RUA Arquitetos desde 2011. O evento é uma exposição de arte contemporânea que conta com programa educativo de oficinas e outras atividades. Seu tema no ano de 2017 foi 'Emergência'. Sua página oficial está disponível em: <http://2017.travessias.org.br>. Acesso em: 26 Ago. 2017.

179. A produtora Automatica é coordenada pelo trio de irmãs Mariana, Luiza e Marisa Mello que colaboram com o Observatório de Favelas e a Redes da Maré há mais de dez anos. Sua página oficial está disponível em: <http://www.automatica.art.br>. Acesso em: 26 Ago. 2017.

180. O escritório RUA Arquitetos é formado pelos arquitetos cariocas Pedro Évora e Pedro Rivera que colaboram com o Observatório de Favelas e a Redes da Maré há mais de seis anos. Sua página oficial está disponível em: < http://www.rualab.com/>. Acesso em: 26 Ago. 2017.

181. Os projetos das exposições podem ser acessados através da página do RUA Arquitetos.

Disponível em: < http://www.rualab.com/portfolio/65,5774>. Acesso em: 26 Ago. 2017. 


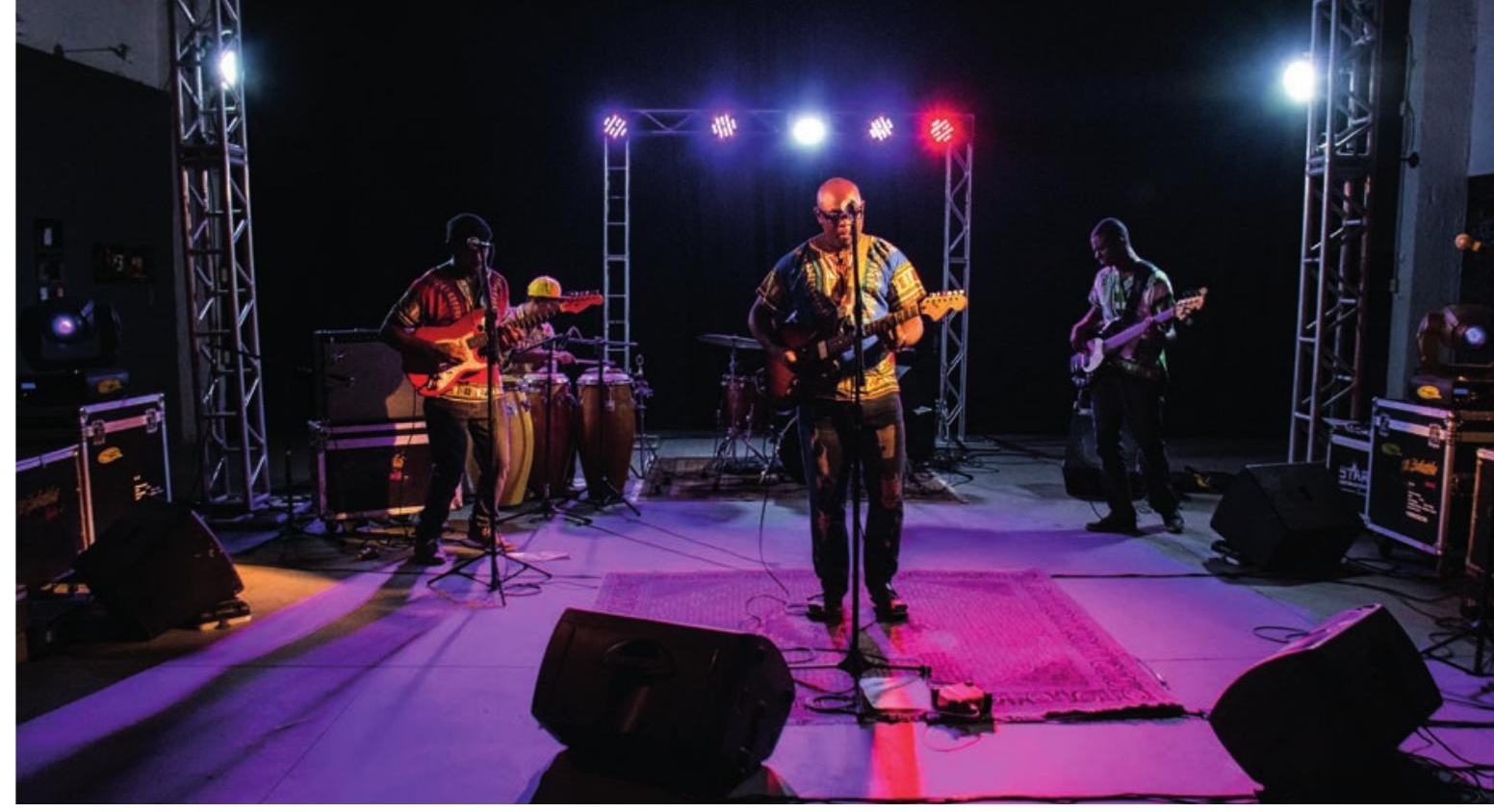

Figura 37: concerto de música do cantor africano Zola Star. Fonte: fotógrafo Douglas Lopes, 2017.

te, que são os momentos em que ocorrem aulas de ballet infantil e yoga para idosos, além de haver shows e apresentações, que são frequentes no local. Tive a oportunidade de assistir algumas dessas aulas e participar de eventos à noite, como a realização do concerto do cantor africano Zola Star (figura 37) e o espetáculo 'Obinrin - Ventos na Maré, resultado do projeto Mulheres ao Vento do Coletivo Ao Vento ${ }^{182}$, que trata de assuntos relacionados aos temas empoderamento feminino, artes e africanidade.

Vale ressaltar também uma experiência que participei e foi muito marcante no processo. Um dos eventos realizados pelo CAM foi a exibição de um curta-metragem desenvolvido pela equipe do Mão na Lata no galpão Bela Maré. Na ocasião fui designada a levar mais de vinte crianças participantes do projeto Nenhum a Menos em uma Kombi, partindo da Lona Cultural até o CAM, a fim de auxiliar outros colaboradores que levariam outras crianças. Esta foi uma experiência particular, pois ver as crianças da Lona Cultural em outro espaço completamente diferente, me fez perceber como há uma real distância simbólica dentro da própria Maré, claramente percebida na animação das crianças que experienciavam o CAM de forma diversa dos outros frequentadores, com curiosidade, interesse e exaltação.

182. Coletivo Ao Vento. Página oficial. Disponível em: <https://www.facebook.com/mulheresaovento>. Acesso em 26 Ago. 2017. 
Outra vivência relevante ocorreu quando visitei o CAM durante uma reunião de equipe sobre o espaço. Nesta reunião estavam diversos colaboradores que discutiam sobre a liberdade de uso do banheiro e bebedouro, já que muitos moradores em situação de rua pediam para utilizar, sobre a inclusão de mais pessoas no cotidiano do Centro de Artes, de forma que o local fosse mais atrativo para moradores da Maré, sobre a manutenção do espaço, entre outros.

Foi curioso notar que embora seja um espaço privado, seu caráter coletivo não é perdido, visto que seus coordenadores e colaboradores procuram ao máximo deixar o uso do espaço democrático e aberto, ainda que lidem com dificuldades cotidianas com organização e infraestrutura. O CAM é um espaço aberto para a produção de cultura, o que faz com que muitas pessoas do Rio de Janeiro, de outras partes do Brasil e de fora do país visitem o local e se engajem em suas atividades e eventos.

\subsubsection{Reflexões e aprendizados}

Cada uma dessas vivências foi essencial para compreender as dinâmicas do Complexo da Maré e como os parceiros da pesquisa atuam e se articulam no território. Ficou evidente que a produção cultural é um meio forte pelo qual muitos atores se reúnem no local para discutir assuntos complexos, evidenciar questões e colocá-las a público para que uma audiência ampliada possa visualizar a resistência cotidiana. Além disso, pude notar como o caráter mutante da Maré é reverberado em tudo que acontece por lá, de forma que a habilidade e flexibilidade no fazer são aptidões locais continuamente elaboradas no dia-a-dia.

Outro ponto importante está na conquista da minha autonomia, que possibilitou que eu reconhecesse o território como um espaço rico e plural que poderia fornecer não só muitos aprendizados para a minha atuação como designer, mas também para a minha própria vida. Após a conquista de autonomia, a minha participação também foi modificada, de modo que eu pude me infiltrar melhor, percorrer outros espaços que eu não conhecia, interagir com outros atores da Redes da Maré, conhecer outros projetos, a multiplicidade de usos e formas de fazer e compreender melhor as dinâmicas espa- 
ciais cotidianas. Isto propiciou também que a minha atitude de observadora já começasse a migrar para a de propositiva ainda que pontualmente em atividades simples.

Todavia, apesar de conseguir apreender o território e visualizar as diferentes camadas de complexidade, eu ainda não via possibilidades reais para desenvolver algum processo colaborativo, ainda que fosse no âmbito das atividades cotidianas, visto que colocar as abordagens em prática soava como um desafio, especialmente as etapas iniciais vistas em projetos de codesign e design social participativo que envolvem encontros, engajamento social e o interesse coletivo. Quanto mais eu conhecia em detalhes os espaços, suas complexidades e as relações existentes, maior era a autonomia que eu recebia dos meus parceiros para engajar em atividades cotidianas, porém eu não enxergava brechas para introduzir uma atitude propositiva projetual. Embora eu tivesse colaborado diversas vezes por meio de projetos de design gráfico e participado de inúmeras atividades que continham traços projetuais, eu ainda não me enxergava organizando uma prática de codesign, ao passo que pensei em abrir mão de realizar algo coletivamente que engajasse um processo projetual nas abordagens escolhidas inicialmente - design anthropology, codesign e design social participativo -para apenas documentar os aprendizados levantados nas vivências.

Observei naquele momento que realizar atividades de codesign sem condições propícias, como recursos, equipe e organização com os parceiros seria praticamente impossível. Neste sentido, optei por não me prender a proposição e foquei em concluir meu processo de observação participante com as pessoas, visto que já tinha levantado muitos aspectos para análise. Entretanto, seguindo a proposta de DA, apoiei-me na ideia de correspondência, tal qual sugerida por Tim Ingold (2016, p. 20), que representa uma "maneira de se relacionar de um ser que habita no hábito, cuja agência é sempre emergente e cuja postura é atencional”183. Em outras palavras, assumir a correspondência representaria me deixar levar no cotidiano da Redes da Maré e dos parceiros, sempre atenta e na escuta, de forma que o 'fazer' não partiria de mim, mas emergiria com a convivência ao me colocar interessada e disponível para esta reciprocidade. 
Estas observações são detalhadas no próximo capítulo, em que me debruço sobre as reflexões levantadas em campo e os desafios de se promover a colaboração em design. De todo modo, neste interstício, abri mão da ação propositiva e, quando eu menos esperava, uma oportunidade para desenvolver um processo colaborativo de design surgiu em uma conversa cotidiana. No próximo tópico narro a última fase que vivenciei em campo, na qual efetivamente ocorreu um processo colaborativo de design, e pude navegar da observação para a ação com Lino, Lopes e muitos outros parceiros da Redes da Maré.

\subsection{Da observação para a ação: a proposição em demandas locais}

Ao final do período de imersão, durante a última semana acompanhando as atividades cotidianas, notei uma grande dificuldade em chegar a uma questão de interesse junto a Lino e Lopes de forma que pudéssemos realizar uma atividade colaborativa. Todavia, nos últimos dias em que estive lá, tive a oportunidade de conversar com Lino, que me pediu para desenvolver uma estante para o CAM que atraísse mais pessoas da Maré para o espaço durante o dia, quando usualmente ficava vazio.

Refleti brevemente, ainda durante a conversa, sobre o seu pedido e comecei a questioná-la sobre seus detalhes, realizando perguntas básicas como: porque uma estante? Qual público irá utilizá-la? Por quem vocês gostariam que o CAM fosse mais utilizado? O que vocês sentem mais falta nesse espaço? Inicialmente com dúvidas, Lino refletiu e a partir destas perguntas me propôs que realizássemos uma oficina de marcenaria na qual construiríamos mobiliários para CAM, fosse uma estante ou outros objetos que pudessem ampliar o uso do espaço pelas pessoas durante no dia-a-dia.

Em meados da última semana de abril, iniciei o desenvolvimento da proposta de forma que todos tivessem tempo de se organizar. Pedi auxílio ao Dr. Marcos Rosa e juntos estruturamos as possibilidades para esta primeira atividade. Em meio a conversas e discussões, concluímos que deveríamos desenvolver uma atividade que além de ser uma oficina de marcenaria, possibilitasse a construção de peças que atendessem às demandas do CAM, mas que fossem testadas por pessoas que frequentam, trabalham e usam o espaço diariamente. Isto configuraria o nosso workshop como uma oficina 
de marcenaria com o objetivo de realizar construções-testes simples e viáveis dentro do período de uma semana, tempo proposto por Lino.

Em uma tarde, Rosa e eu telefonamos para Lino e propusemos fazer uma oficina de construção-teste, já que seria um caminho que iria além da construção de objetos por si só. Lino concordou com a ideia e disse que se encarregaria de convidar pessoas para participar e que levantaria os materiais que poderiam ser utilizados. Enquanto isso, eu seria responsável por organizar o programa da oficina, alinhado com algumas demandas já anunciadas por Lino, de maneira que a atividade possuísse algum planejamento para execução de peças. Assim, Lino compartilhou algumas demandas imediatas que eles possuíam no local:

- Bancos para os banheiros masculino e feminino. O Centro de Artes possui em sua programação diversas atividades de dança, teatro, ginástica, yoga, entre outras, e por conta disso, frequentadores precisavam de um espaço para se trocar confortavelmente;

- Suporte para pendurar bolsas e roupas nos banheiros. Seguindo a mesma demanda anterior, esta visava atender as pessoas que estão sempre frequentando o espaço e precisam de infraestrutura para se arrumar de forma que não tenham que colocar seus pertences no chão.

- Estantes para armazenar objetos e materiais do espaço. O espaço do CAM é um galpão alto e de grande profundidade, porém suas paredes longas e altas dificultam a organização dos diversos materiais lá utilizados, tais como livros, discos de vinil, vitrola, instrumentos musicais e outros.

- Prateleiras para o depósito. No fundo do galpão, atrás do palco e da coxia, há um espaço reservado para o depósito de materiais e objetos, alguns em uso, outros acumulados e guardados. Separado por uma parede de drywall, o depósito é um espaço que contém diversos objetos acumulados - sendo esta uma característica comum na Maré - como ripas de madeira, calhas de alumínio, caixas de papelão, o banco de uma Kombi, livros, materiais gráficos de eventos passados, baús com roupas de espetáculos, caixa com tapetinhos de yoga, e muitos outros. 
- Baú para cenários e para materiais de oficinas. Há muitos objetos que precisam ser armazenados e organizados a fim de preservá-los, como ferramentas, roupas, sapatos, instrumentos e outros que, muitas vezes, são empilhados e guardados de forma inapropriada no local.

- Áreas de convívio e espaços para sentar. Lino apontou a falta de espaços de convívio, pois observava o CAM como um espaço para pessoas se encontrarem e passarem à tarde, de maneira que possam acompanhar as atividades que por lá ocorrem semanalmente, difundindo a arte com mais moradores da Maré.

Levando em consideração as suas observações, iniciei a organização da oficina desenvolvendo peças gráficas para divulgação, a proposta da atividade e o número de dias e horários, enquanto Lino e Lopes levantariam os materiais disponíveis, convidariam participantes para integrar a atividade e documentariam todo o processo. Algumas semanas depois desta ocasião, nos comunicamos novamente e Lino sugeriu que marcássemos o evento nos dias 22, 23, 24 e 25 de maio de 2017.

No intuito de não realizar a oficina sozinha, convidei o designer Vinicius Mesquita do escritório de design $O$ Formigueiro ${ }^{184}$ para a atividade, já que ele conhecia a Maré e já havia desenvolvido uma atividade colaborativa de construção de um banco para a área externa do CAM com Lino e Lopes alguns meses antes. Além disso, éramos colegas da PUC-Rio, já que nos graduamos juntos no Departamento de Artes e Design e possuíamos uma mentalidade semelhante para processos participativos em design. Mesquita aceitou a proposta e nos organizamos para realizar a programação da oficina.

\subsubsection{Programação para oficina de construção-teste no Centro de Artes da Maré}

Com tudo acertado entre os atores participantes, organizei-me com Mesquita e estruturamos quais seriam as etapas da atividade, isto é, o que ocorreria, quais atores fariam o que em quais momentos e quais materiais utilizaríamos levando em consideração o que já sabíamos que estaria disponível. Neste processo iniciamos o formato da oficina

184. O Formigueiro é um escritório de design oriundo de designers formados na PUC-Rio, entre eles Caio Bahouth, Lucas Portes e Vinicius Mesquita. Página oficial do escritório de design. Disponível em: <http://www.oformigueiro.com.br/>. Acesso em: 10 Abr. 2017. 


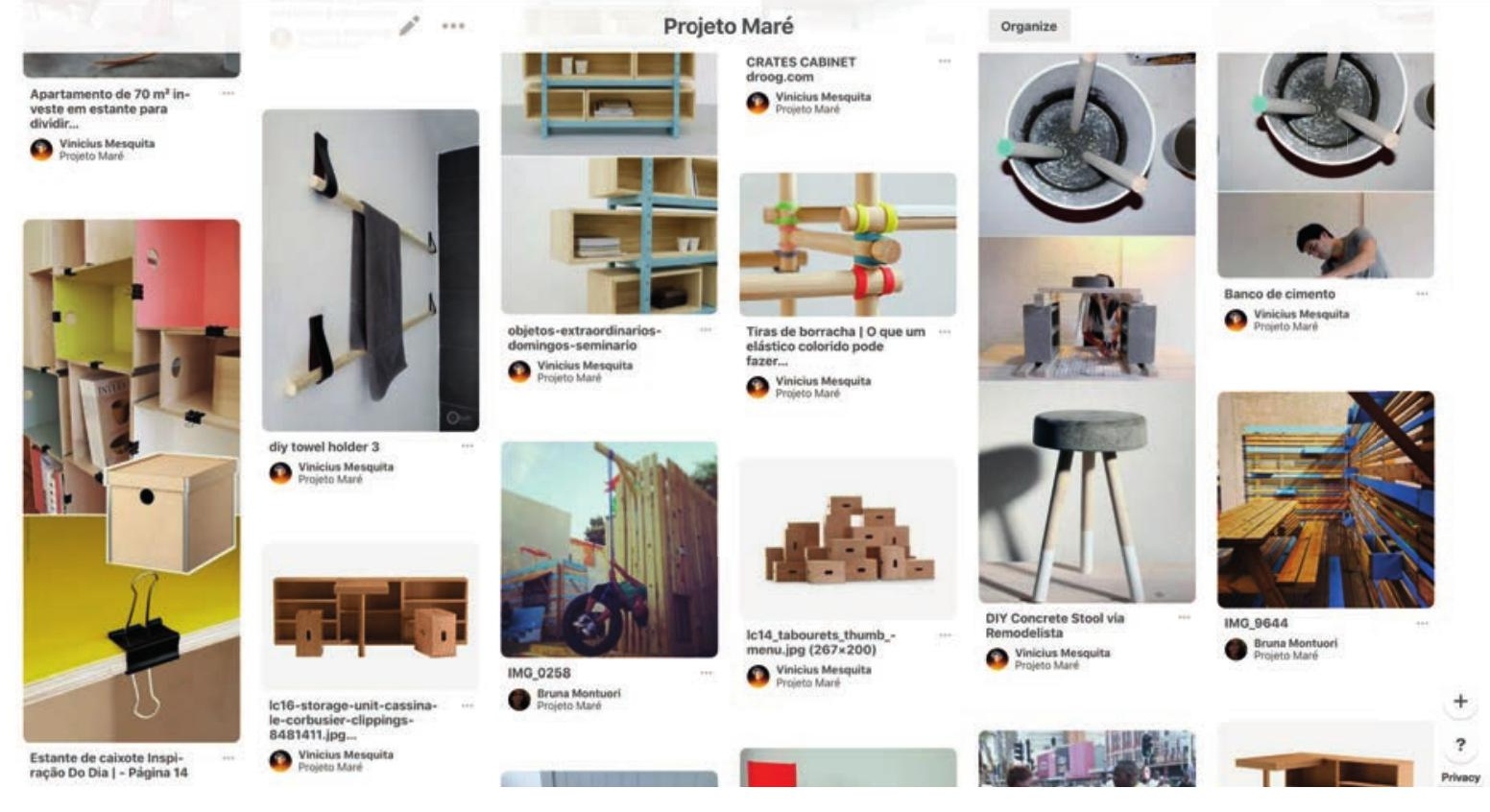

Figura 38: algumas referências levantas na plataforma Pinterest. Fonte: captura de tela da página web Pinterest, 2017.

elencando referências em uma plataforma web chamada Pinterest ${ }^{185}$, que permite a compilação de ideias em 'painéis' baseados em algumas das demandas apontadas por Lino. O objetivo desta busca foi tornar o processo objetivo, visto que teríamos poucos dias para realizar a atividade, porém sem enrijecê-lo, pois sabíamos que lidaríamos com imprevisibilidades e particularidades que só são percebidas em campo.

Sabendo que trabalharíamos com tempo curto para execução e com escassez de recursos e ferramentas, ao levantarmos referências focamos em projetos com praticidade de construção e com materiais simples, baratos e fáceis de encontrar, mas que poderiam funcionar bem para a construção dos testes. Mesquita, com sua aptidão em técnicas de construção, montagem e desenho, buscou situações que seriam facilmente adaptáveis ao local. Enquanto isso, foquei em referências que poderiam auxiliar na formatação do programa da oficina, como ferramentas de engajamento, percepção da identidade local, memória e pertencimento (figura 38). 

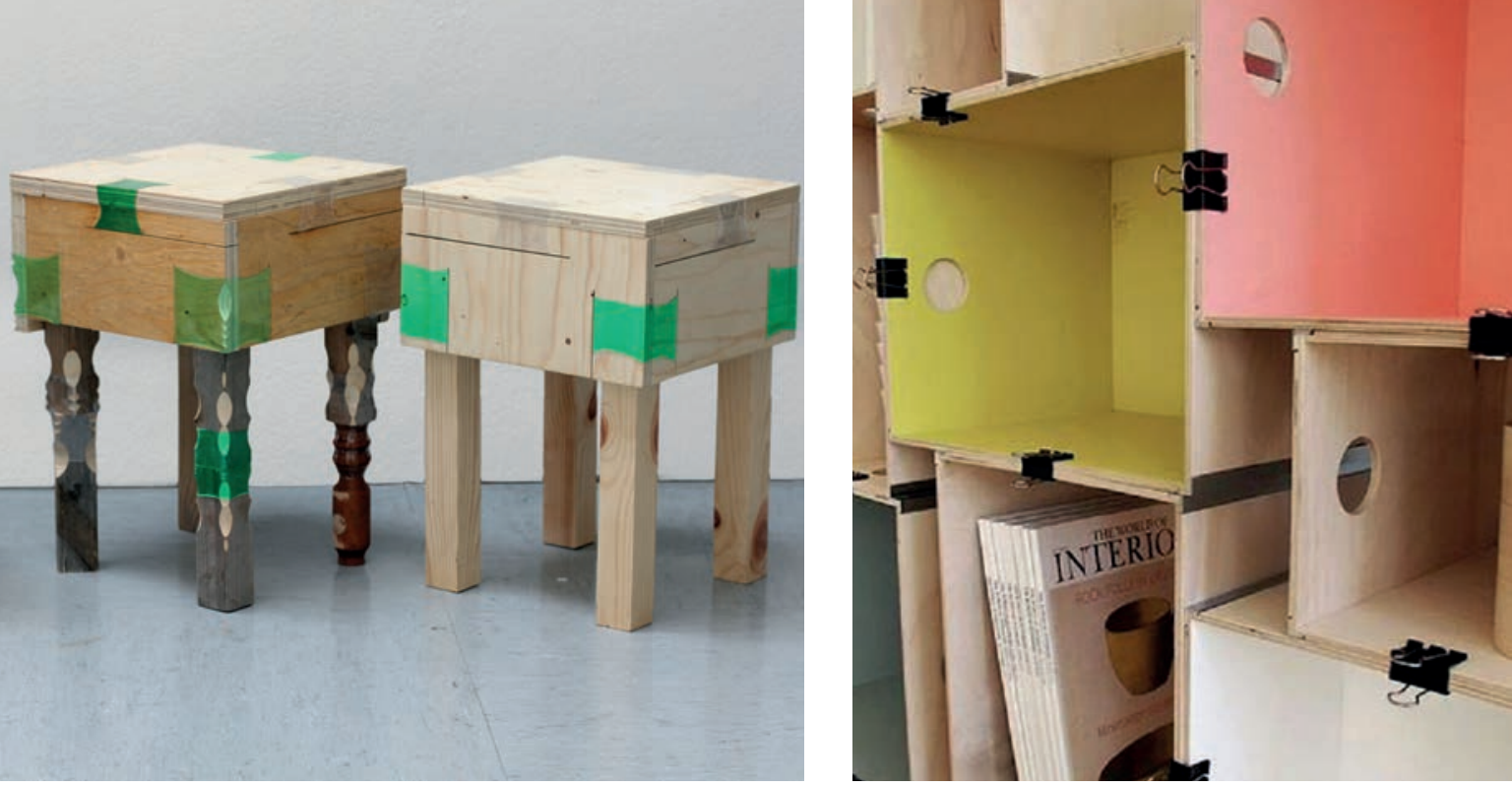

Figuras 39 e 40: bancos com solda de garrafa pet e caixas presas com prendedores de papel. Fonte: imagens extraídas da página web Pinterest, 2017.

Buscamos referências de engajamento em práticas de design colaborativo, como as atividades desenvolvidas pelos grupos Public Workshop ${ }^{186}$ e Project for Public Spaces ${ }^{187}$, já habituados a realizar atividades em diversos lugares, especialmente em circunstâncias semelhantes às nossas. Entre algumas práticas, os grupos usavam técnicas de escrita e desenho em que os participantes poderiam colocar frases, ideias e desejos para os espaços que estavam projetando coletivamente, algo viável do ponto de vista de engajamento. Além disso, encontramos algumas referências interessantes que poderiam ser úteis, como as técnicas de solda com garrafa pet desenvolvidas por alunos da Royal College of Art, em Londres ${ }^{188}$ (figura 39), prendedores de papel pretos que serviriam para juntar caixas (figura 40) e outras que envolviam o conceito de 'gambiarra' - defini-

186. Public Workshop é um grupo de arquitetos e designers, baseados na Filadélfia, Pensilvânia, Estados Unidos, que atua com diferentes comunidades com o objetivo de realizar atividades participativas de construção de mobiliários urbanos de acordo com as demandas e interesses locais. Disponível em: http://publicworkshop.us/

187. Project for Public Spaces (PPS), em português "Projeto para Espaços Públicos", é uma organização internacional que atua no movimento placemaking com diversos parceiros na transformação e requalificação de espaços públicos em diferentes cidades com equipes locais e participação da sociedade civil. Disponível em: https://www.pps.org/

188. Cf. TUCKER, E. Micaella Pedros uses heat-shrunk plastic bottles to join furniture. Dezeen, 30, jun 2016. Disponível em: <https://www.dezeen.com/2016/06/30/micaella-pedros-royal-college-of-art-graduate-showrca-joining-bottles-wood-furniture-recycled-plastic/>. Acesso em: 10 Mai. 2017. 
do no capítulo quatro - a partir da apropriação espontânea de objetos que eram utilizados com objetivos diferentes daquele originalmente concebido para o objeto.

Levantamos referências por duas semanas e na semana anterior à oficina organizamos o programa. Inicialmente havíamos agendado a oficina nos dias 22, 23, 24 e 25 de maio, de segunda até quinta-feira, no entanto, antes da montagem do programa, recebi uma mensagem de Lino pedindo que modificássemos um pouco as datas. Segundo ela, a Redes da Maré estava organizando uma marcha contra a violência na quarta-feira, dia 24 de maio, visto que os confrontos nas favelas estavam em estado de calamidade. Em razão disso, reprogramamos o programa de oficina para os dias 22, 23, 25 e 26 de maio (segunda, terça, quinta e sexta-feira) das catorze às dezoito horas, pulando o dia da marcha.

Ficamos um pouco perdidos no primeiro momento, mas aceitamos a mudança e compreendemos a urgência em realizar o evento diante da complexa situação. Desta maneira, programamos os dois primeiros dias para atividades de compreensão das demandas do espaço do CAM, a partir do levantamento dos usos e do público usuário do espaço, bem como uma atividade de reconhecimento espacial e brainstorming do inglês 'tempestade de ideias', e deixamos as fases de construção e execução para depois da marcha, de modo que tivéssemos maior suporte da equipe do CAM durante estas partes da oficina.

Por este caminho, Mesquita e eu estruturamos o programa de forma que a quarta-feira, dia da marcha contra violência, seria usada para buscar materiais simples que poderiam ser úteis, tais como pregos, parafusos, buchas, dobradiças, caixas de fruta, pallets, mãos-francesas e outros, que seriam adquiridos para usos básicos de construção durante a quinta e a sexta-feira. Desta forma, organizamos o roteiro da oficina de acordo com o seguinte programa:

\section{Primeiro dia: segunda-feira, 22 de maio}

Mesquita e eu receberíamos os participantes, nos apresentaríamos, descreveríamos a oficina e o motivo de sermos convidados, explicaríamos o que é uma construção teste e iniciaríamos uma conversa sobre o funcionamento e o uso do espaço para pensar- 
mos em coisas para o lugar. Nesta conversa levantaríamos algumas perguntas, como: as pessoas estão usando o espaço ou ele está vazio? O espaço é usado por pessoas de diferentes idades? As pessoas frequentam este espaço em grupos ou sozinhas? Quantos tipos diferentes de atividades acontecem nesse lugar? Quais partes do espaço estão sendo utilizadas e quais não estão? Há opções de coisas para fazer? Quem organiza esse espaço? Há um organizador? Quem é responsável pelo espaço? Este é um espaço que você escolheria para encontrar seus amigos? Existem outras pessoas no espaço encontrando amigos? Será que as pessoas trazem seus amigos e parentes para ver o lugar ou mostrar alguma de suas características com orgulho? Será que as pessoas usam o local regularmente e por escolha própria? As pessoas cuidam desse lugar quando vem nele?

Após a roda de discussão, colocaríamos no quadro negro ou em um papel grande informações úteis levantadas com as perguntas e, na sequência, iniciaríamos duas rodadas de geração de ideias individual e coletiva. Assim, todos apresentariam suas ideias e discutiríamos fatores que limitam ou impedem o desenvolvimento de algumas delas, já filtrando para as viáveis e possíveis de realizarmos. Alguns fatores limitantes seriam: poucos recursos disponíveis, pouco tempo para execução, a existência de algumas demandas já existentes e a importância de valorizarmos a identidade e o pertencimento com a Maré.

Em seguida, debateríamos a relação de demandas reais e demandas de desejos levantadas, e tentaríamos buscar juntos um 'DNA da Maré, isto é, características locais que atendem a identidade e os usos diários das pessoas a partir de elementos locais, materiais identificados, memórias e linguagem. Assim, caminharíamos pelo CAM e depois pela Maré para levantarmos tais elementos. Ao final do dia, após a caminhada, faríamos uma roda de conversa final sobre a definição dos elementos escolhidos, materiais que utilizaríamos e o 'DNA da Maré', a fim de nos prepararmos para o próximo dia.

\section{Segundo dia: terça-feira, 23 de maio}

Seria realizada uma atividade de desconstrução sobre a ideia dos objetos, trabalhando a subversão do uso e do espaço. Em seguida, apresentaríamos as referências levantadas na plataforma Pinterest utilizando o projetor do CAM para que todos pudessem 
ver ideias viáveis e interessantes a fim de ampliar o repertório dos participantes. Na sequência, faríamos um desenho coletivo dos espaços do CAM, como uma planta, maquete improvisada ou através de marcações no chão com giz definindo medidas de espaços. Ao final, desenvolveríamos desenhos de possíveis objetos que construiríamos juntos, definindo materiais e ferramentas.

\section{Dia livre, quarta-feira, 24 de maio}

Eu ficaria responsável por buscar materiais adicionais para auxiliar na montagem, enquanto ocorreria a Marcha Contra Violência na Maré.

\section{Terceiro dia: quinta-feira, 25 de maio}

O objetivo principal seria migrarmos do desenho coletivo para a prática por meio da apresentação de máquinas e ferramentas e de materiais e sua maneabilidade, partindo para a produção e execução dos objetos definidos.

\section{Quarto dia: sexta-feira, 26 de maio}

Terminaríamos a produção das peças, iniciaríamos o acabamento, replicaríamos peças que fossem possíveis e finalizaríamos a atividade com agradecimentos e registros fotográficos.

Embora tivéssemos em mente que o cronograma no papel representava apenas orientações de como conduziríamos o processo, sabíamos que em campo tudo poderia ocorrer de forma diferente e por isso nos preparamos para todos os possíveis imprevistos. A seguir, relato o que ocorreu em todos os dias da oficina, apresentando o processo colaborativo.

\subsubsection{Entre improvisação e apropriação: a oficina de marcenaria e construção teste}

No dia 22 de maio, segunda-feira, entrei em contato com Lino e Lopes para avisar que estava a caminho do CAM com Mesquita, com previsão de chegada ao local às treze horas e trinta minutos. Lino estava atribulada com o preparo da Marcha Contra Violência na Maré, visto que um dos objetivos para o evento era a transformação 
da fronteira entre a Nova Holanda e a Nova Maré em uma praça com um pequeno parquinho para as crianças. Lino, em parceria com a Comlurb ${ }^{189}$, conseguiu articular a transformação da área de forma que os garis construíssem um espaço para crianças.

Em razão disso, o CAM estava vazio quando chegamos e ficamos aguardando Lino e Lopes no local, observando seus espaços e as possibilidades. Por volta de catorze horas, Lino chegou e contou como estava atribulada com a marcha e nos contou sobre a urgência de sua realização, visto que o número de jovens mortos em virtude de confrontos já pairava em onze antes do término do primeiro semestre de 2017 , praticamente alcançando o total do ano de 2016, que chegou em dezesseis mortos. Além disso, nos contou como as aproximações com o poder público estavam ainda mais complicadas e como a polícia parecia a cada ano mais despreparada para lidar com o conflito das favelas. Por este motivo, nos explicou que muitas pessoas estavam envolvidas com a Marcha Contra Violência e que participariam do evento a fim de dar visibilidade para a situação. Por conta disso, ela não conseguiria nos dar o suporte necessário para a realização da oficina como havíamos combinado.

Compreendemos a situação e conversamos com Lino se deveríamos modificar a data da oficina, no entanto, acordamos em dar sequência a atividade, ainda que não pudéssemos contar com ela diretamente, que se colocou à disposição dentro de suas limitações. Concordamos e ficamos aguardando pessoas para começar o evento enquanto preparamos um espaço para iniciar a atividade em uma mesa do CAM, trazendo cadeiras para que os participantes pudessem sentar.

Até às quinze horas ainda não havia pessoas para participar e estavam no CAM apenas os conhecidos que frequentavam o local no dia-a-dia. Desta forma, Mesquita e eu ficamos um pouco em dúvida do que fazer, mas nos decidimos realizar a oficina com quem estava lá, visto que todos ali conheciam muito bem o CAM. Convidamos quem estava no local no momento, isto é, Douglas Lopes (designer e fotógrafo da Redes da Maré), Iury Lobo (colaborador do CAM e produtor cultural), Daniel Remlik (colaborador e educador do CAM), Maurício (colaborador do CAM), Rodrigo Maré (professor de 
percussão no CAM e articulador cultural da Maré) e Julia Rossi (integrante do Muda Maré), que aceitaram participar e sentaram à mesa conosco.

Iniciamos a atividade nos apresentando, falando sobre os nossos trabalhos e o motivo de estarmos ali para realizar aquela atividade a partir da troca com Lino e outros colaboradores da Redes da Maré. Lançamos algumas perguntas da lista que havíamos preparado para iniciar um bate-papo e conversamos sobre a Maré e o CAM, o cotidiano do espaço e a percepção de cada pessoa sobre o local. Para tanto, usamos uma cartolina de forma que pudéssemos ir escrevendo nossas percepções no papel.

Várias reflexões foram expostas, tais como: falta de lugar para guardar instrumentos musicais de percussão, fazendo com que estes ficassem empilhados; falta de infraestrutura para os alunos da Escola Livre de Dança, que não possuem muitos espaços para sentar e apoiar mochilas; uso frequente do espaço para reuniões da Redes da Maré e a ausência de mesas e cadeiras para este tipo de atividade; desorganização do depósito, que estava com muitos materiais acumulados e empilhados; falta de um camarim para os frequentes concertos e espetáculos no CAM, impedindo o conforto de convidados e artistas; desorganização dos livros expostos e falta de uma biblioteca com espaço para leitura e estudo; falta de mobiliários portáteis, visto que o CAM tem seu espaço modificado cotidianamente; falta de divulgação na entrada do espaço sobre as atividades internas; falta de estrutura para crianças brincarem, lerem e desenharem; falta de um suporte para mangueira, utilizada frequentemente para a limpeza do espaço; entre outras constatações.

Um ponto comum para todos ali que conheciam o CAM há anos, era o fato de o espaço ser muito amplo, mas pouco estruturado com mobiliários, o que desencadeava um menor convívio durante o dia, fato que eu mesma havia notado durante a minha imersão na Maré. Neste sentido, partimos desta discussão para a atividade de geração de ideias para o local, inicialmente através de um brainstorming individual em uma folha tamanho A5 com a frase "Este lugar precisa de..." (figura 41), que entregamos para cada um dos participantes.

Enquanto todos escreviam, eu e Mesquita registramos o processo em que várias ideias eram colocadas no papel pelos participantes (figura 42). Após esta atividade, iniciamos 
rede para deitar e descansar; um fraldário; uma televisão ligada durante o dia; uma caixa de sugestões; uma rádio do CAM; uma sinalização mais visível; uma área de convivência externa; uma loja para troca de coisas; um palco móvel; sofás, mesas, poltronas e prateleiras; um suporte para mangueira; um suporte para cartazes; iluminação especial criando micro-espaços; um vestiário no banheiro; móveis do lado de fora; armários e um camarim; um outdoor colorido e iluminado; espaços para leitura, música, jogos de tabuleiro e cartas; e pontos para doações de itens básicos.

Debatemos as ideias e as possibilidades e trouxemos na sequência os fatores limitantes que levantamos durante a organização do programa da oficina: poucos recursos, pouco tempo de construção, as demandas levantadas por Lino citadas anteriormente, a valorização da identidade da Maré e o pertencimento com o espaço. Ao tocarmos neste ponto, um dos participantes sugeriu que caminhássemos pelo espaço do CAM e olhássemos a disponibilidade de materiais no depósito. Observamos todo o espaço e realizamos um esboço no lado oposto da cartolina com ideias estabelecendo um 'diagnóstico' para o espaço. A partir desta troca, finalizamos o dia com algumas ideias principais: projetar um espaço de convívio para descanso, bancos para os banheiros, um suporte para pendurar bolsas e mochilas no banheiro e um suporte para mangueira. Estas ideias seriam levadas conosco e no dia seguinte daríamos continuidade ao processo.

No dia 23 de maio, terça-feira, nos dirigimos ao CAM a fim de dar sequência ao segundo dia da oficina de construção-teste. Ao chegarmos, ficamos aguardando os participantes e algo inesperado ocorreu: as pessoas que participaram no dia anterior estavam agora muito ocupadas com a marcha que ocorreria no dia seguinte, porém, outros moradores da Maré apareceram no CAM procurando a oficina e interessados em participar. Entre o novo grupo de participantes estavam duas mulheres aposentadas, uma mãe com um filho criança, uma estudante ainda no ensino médio, além de Lopes e Lobo, que participaram no dia anterior.

Embora estivéssemos confusos pela troca dos participantes, optamos por explicar o primeiro dia para as novas pessoas com a ajuda de Lopes e Lobo, a fim de levantarmos outras percepções e avaliarmos coletivamente se as ideias levantadas no dia anterior condiziam com a impressão de todos. Foi interessante notar que na perspectiva das mulheres aposentadas faltavam espaços para conversar em momentos anteriores 


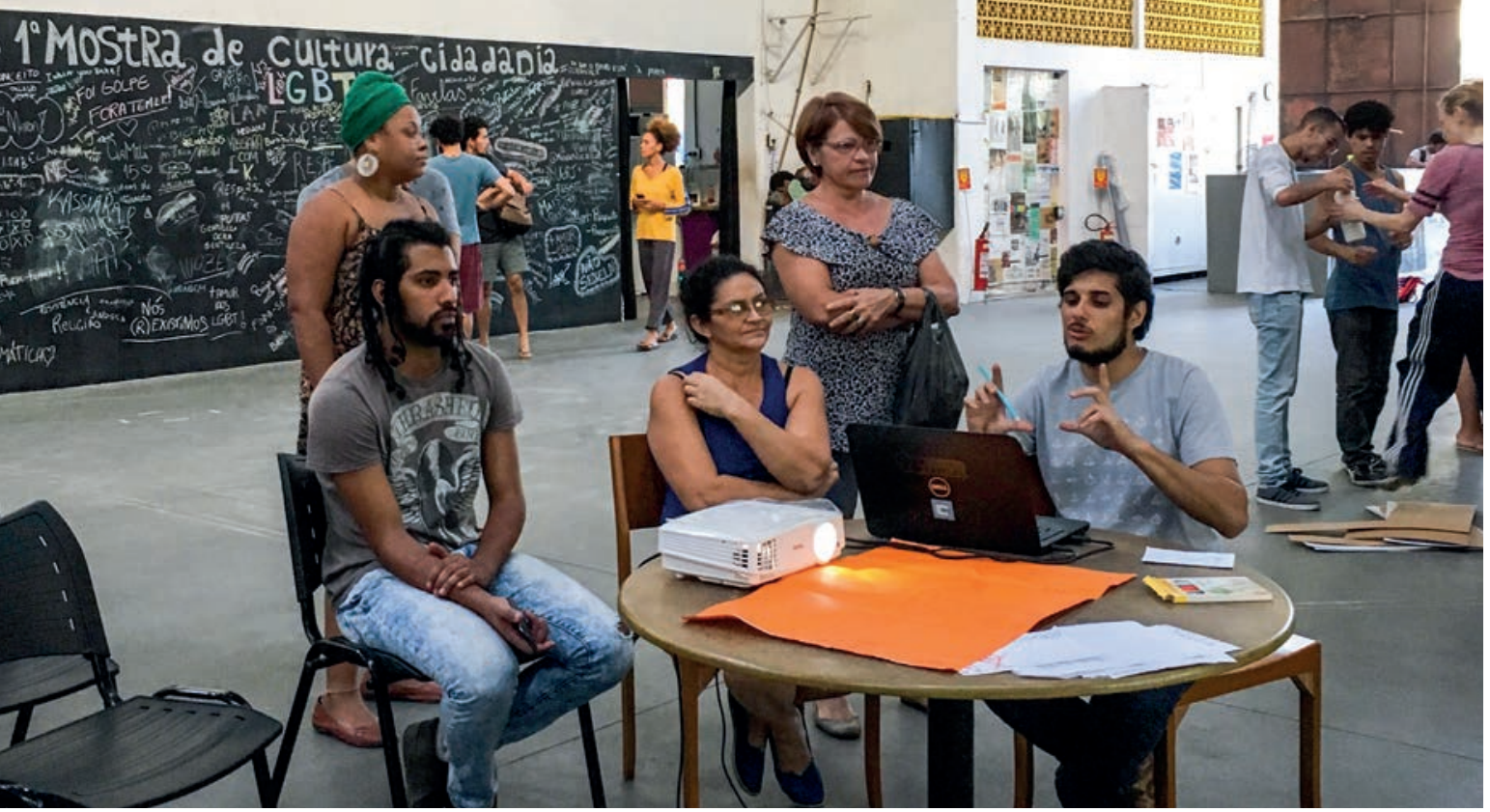

Figura 43: participantes olhando as referências projetadas em uma parede do CAM. Fonte: autora da dissertação, 2017.

e posteriores às atividades que participavam no CAM. Já para a jovem estudante, o CAM não parecia um espaço aberto para moradores da Maré e esta era a sua primeira vez no local, visto que soube da oficina por meio de um anúncio em uma das rádios comunitárias da Maré.

Neste sentido, fizemos um debate sobre qual seria o 'DNA de Maré' em relação aos recursos e a identidade do território. Considerando que todos os participantes eram residentes da Maré, excluindo eu e Mesquita, expressar o que era o 'DNA' do local foi possível através de algumas palavras-chave, como acumulação, imediatismo, urgência, tijolos, construções inacabadas, bicicletas, música alta, mercadinhos e feira livre. A intenção deste processo era promover uma reflexão dos participantes sobre o espaço do CAM em consonância com território da Maré e a sua identidade, especialmente a partir do cotidiano da Nova Holanda. Desta forma, pouco a pouco fomos percebendo o que condizia ou não com o lugar.

Em seguida, projetamos em uma parede do CAM o painel de referências que levantamos na plataforma Pinterest, evidenciando as múltiplas possibilidades que os materiais do depósito poderiam gerar, a fim de chegarmos juntos em uma proposta de construção (figura 43). Após este momento, partimos para uma proposição múltipla que envolvia desenhos, teste com materiais que estavam no depósito e experimentação em alguns espaços. 

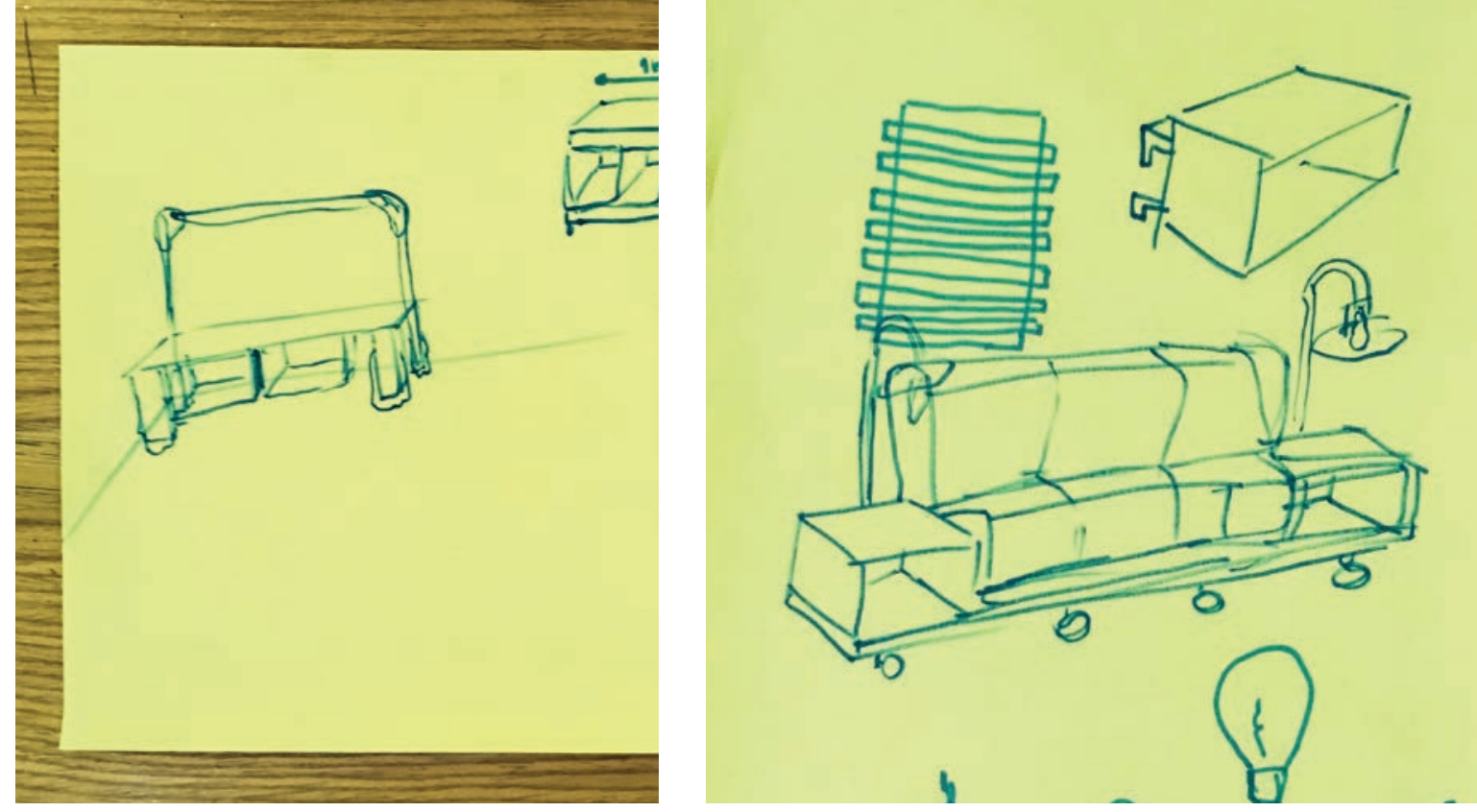

Figura 44: desenhos de experimentação com materiais disponíveis no CAM. Fonte: autora da dissertação, 2017.

Assim, retornamos ao depósito e vimos uma série de poltronas de cinema vermelhas amontoadas que, segundo Lopes, foram doadas ao CAM para a construção de um cinema no local, porém, como o espaço possui um uso multifuncional, instalá-las o enrijeceria, inviabilizando práticas como concertos, espetáculos, exposições de arte, entre outras que exigiam que o espaço fosse modificável. Pegamos algumas poltronas que ainda estavam em boa qualidade, levamos para o meio do CAM para testar e, ao mesmo tempo, iniciamos desenhos com base nos materiais que tínhamos em mãos (figura 44).

Durante o teste das poltronas no chão, discutimos tópicos como ergonomia e posicionamento, visto que eram assuntos muito importantes para chegarmos num mobiliário confortável e de resistência em médio prazo. Assim, avaliamos a possibilidade de construção de um sofá itinerante que contaria com duas poltronas de cinema e rodízios que permitissem a mobilidade do objeto (figura 45).

Além das poltronas, experimentamos a espacialidade dos banheiros a fim de projetarmos juntos um banco para os frequentadores do CAM que participam de aulas, como dança, yoga e performance, incluindo algumas das participantes da oficina. Levamos cadeiras para o banheiro e testamos o espaço ideal para que houvesse conforto para os usuários (figura 46). 

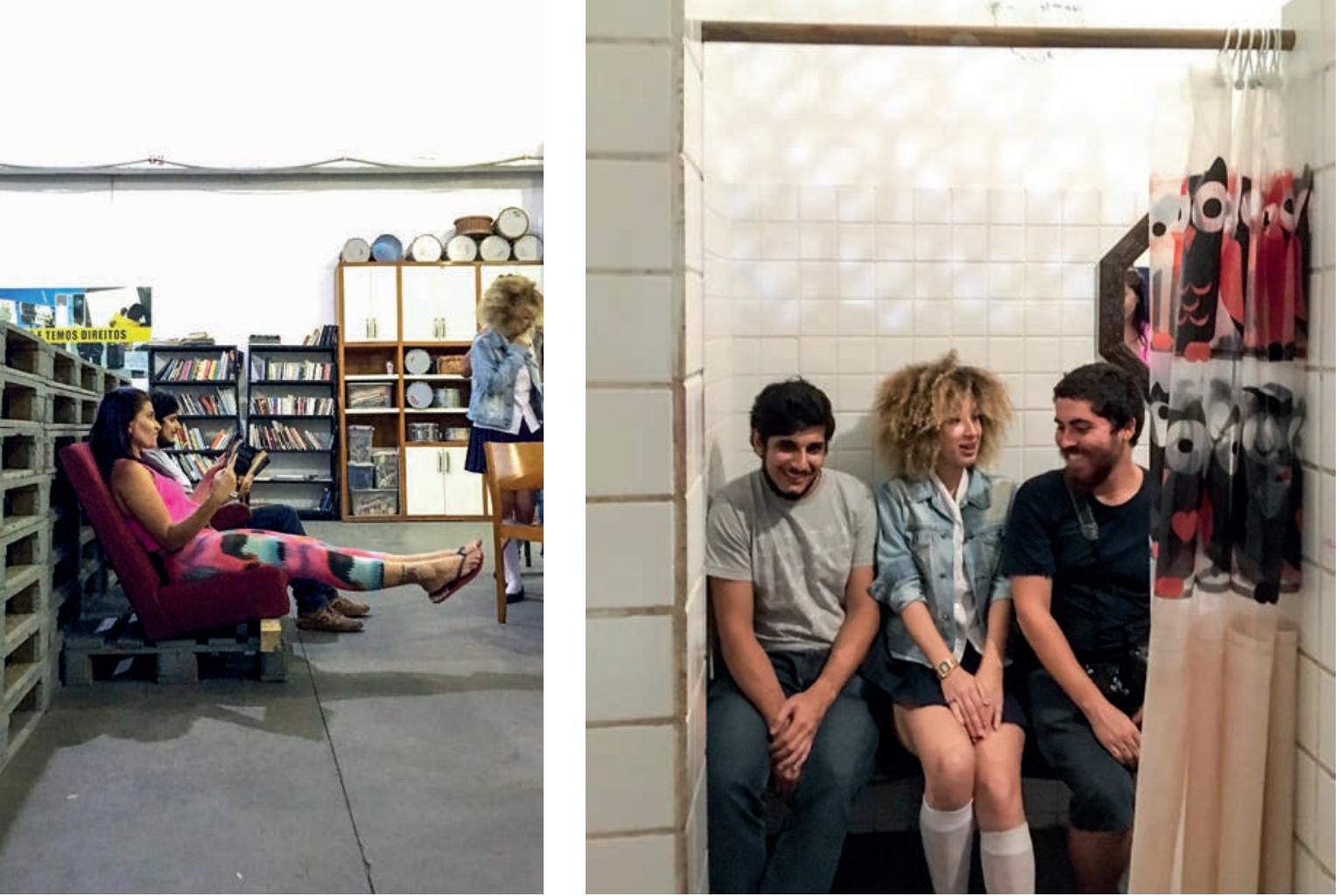

Figuras 45 e 46: experimentando as poltronas, sua altura e posicionamento para o melhor conforto (45) e experimentação da espacialidade dos banheiros do CAM (46). Fonte: autora da dissertação, 2017.

Ao final do segundo dia, estabelecemos materiais que seriam necessários para construção no dia 25 de maio e observamos que enquanto os bancos do banheiro seriam mais simples de construir, seriam necessários suportes, como placas ou pallets, para que as poltronas fossem fixadas. Os bancos do banheiro foram pensados de forma que teriam uma estrutura de compensado para sentar, suportada por quatro 'pernas de três', peça de madeira deixada no depósito e usada para sustentação vertical em obras. As 'pernas de três' seriam cortadas igualmente formando os pés do banco e seriam acopladas a uma caixa de fruta, solucionando a questão do apoio de bolsas, já que não haveria tempo para desenvolver um suporte separado.

Várias ideias para busca de outros materiais necessários foram sugeridas pelos participantes que conheciam muito bem a Maré, como comprar de caixas de fruta por apenas um real no Pexinte ou próximo à Lona Cultural, pedir pallets para uma das fábricas na Rua Flávia Farnese e visitar ferros-velhos da Maré em busca de rodízios e outros materiais. Além disso, muitos participantes propuseram trazer materiais que tinham em casa, como garrafas pet, caixas e outros que estivessem sem uso. 


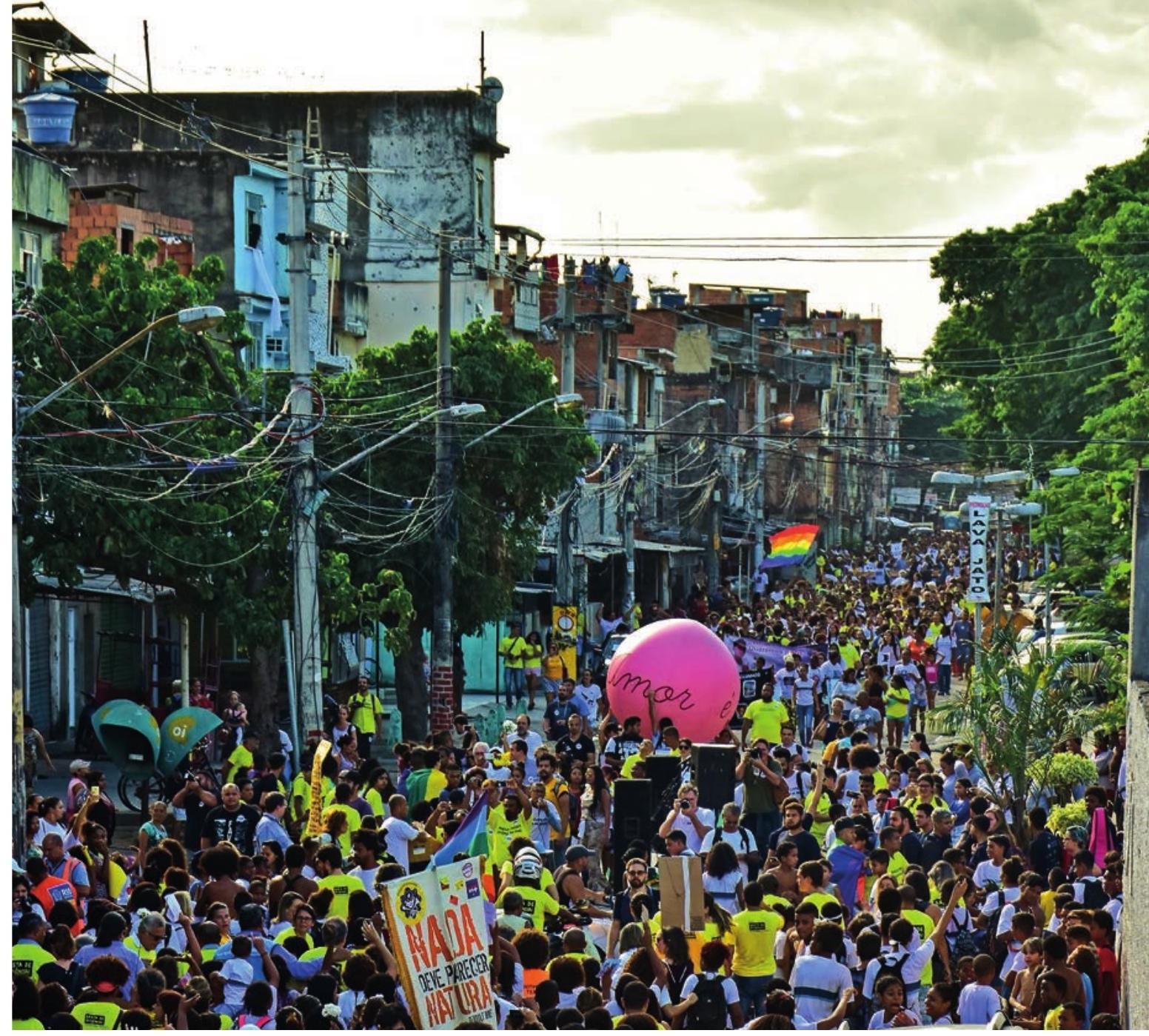

Figuras 47: Marcha Contra Violência na Maré. Fonte: fotógrafo Douglas Lopes, 2017.

No dia 24 de maio, quarta-feira, dia da Marcha Contra Violência na Maré, fui à Maré com a intenção de buscar materiais, enquanto Mesquita separava máquinas em seu ateliê para usarmos no dia seguinte. Uma vez que eu já possuía autonomia para circular pelo território, participei da marcha, que contava com milhares de pessoas de dentro e de fora da Maré clamando por paz (figura 47) e terminava exatamente na área da fronteira, a divisa entre a Nova Holanda e a Nova Maré. O local já não contava com lixo despejado e havia uma praça para crianças brincarem (figura 48).

Na sequência, fui a busca de caixas de fruta e outros materiais. Enquanto o evento terminava, encontrei com Renan Braga e juntos fomos atrás das caixas no Pexinchete, mercado na Nova Holanda em que há muitos resíduos disponíveis. De lá, carregamos seis caixas até o Observatório de Favelas, localizado na entrada da Rua Teixeira 


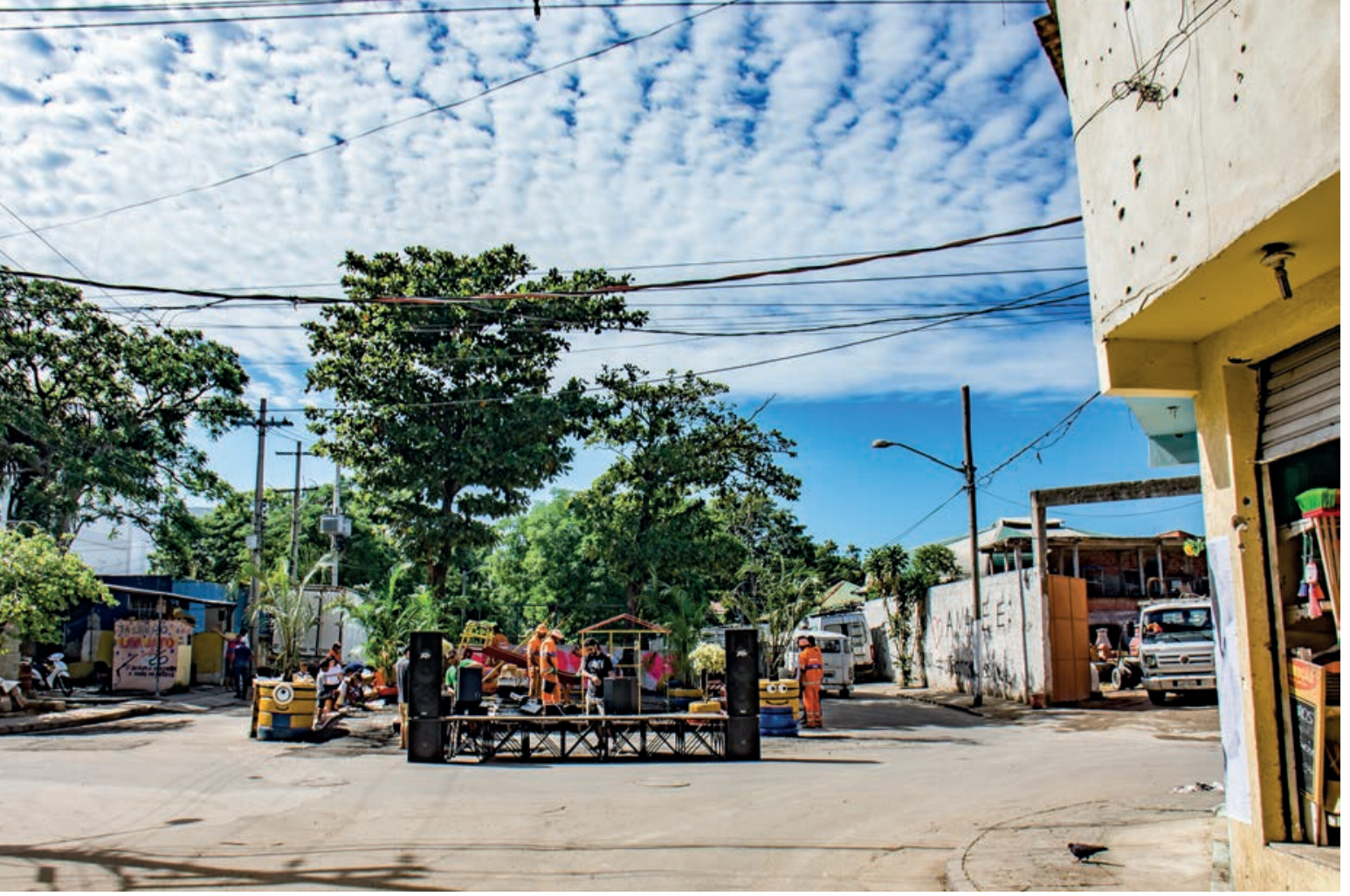

Figuras 48: praça infantil no local da fronteira entre a Nova Holanda e a Nova Maré. Fonte: fotógrafo Douglas Lopes, 2017.

Ribeiro, e voltamos para o CAM, quando Lopes já estava menos atarefado e pôde ajudar. Constatamos que seria preciso comprar outros materiais facilmente encontrados pela Maré, como pallets e rodízios, e combinamos de nos encontrar pela manhã do dia 25 para realizar esta etapa.

No dia 25 de maio, quinta-feira, encontrei-me com Lopes na Praça das Nações, área do Rio de Janeiro que fica exatamente na entrada do Morro do Alemão, cerca de vinte minutos a pé da Maré. Em meio às diversas lojas de construção, compramos parafusos, pregos e porcas e partimos para a Maré em busca dos pallets e dos ferros-velhos.

Ao chegarmos ao CAM, encontramos Mesquita e pedimos a Lino apoio com a Kombi para pegarmos os pallets e as caixas de fruta na sede do Observatório de Favelas. No entanto, já no dia seguinte após a marcha, a Nova Holanda estava sitiada pelo BOPE, que trafegava por algumas ruas da região. Partimos em busca dos materiais que faltavam utilizando um carrinho tipo 'burro sem rabo' (figura 49) pela Avenida Brasil, já que não era possível caminhar pela Nova Holanda. Primeiramente, encontramos um local que vendia os pallets antigos pelo preço de cinco reais e os mais novos por dez reais. Optamos por não adquirir o material e fomos até a fábrica da Ediouro, uma pro- 

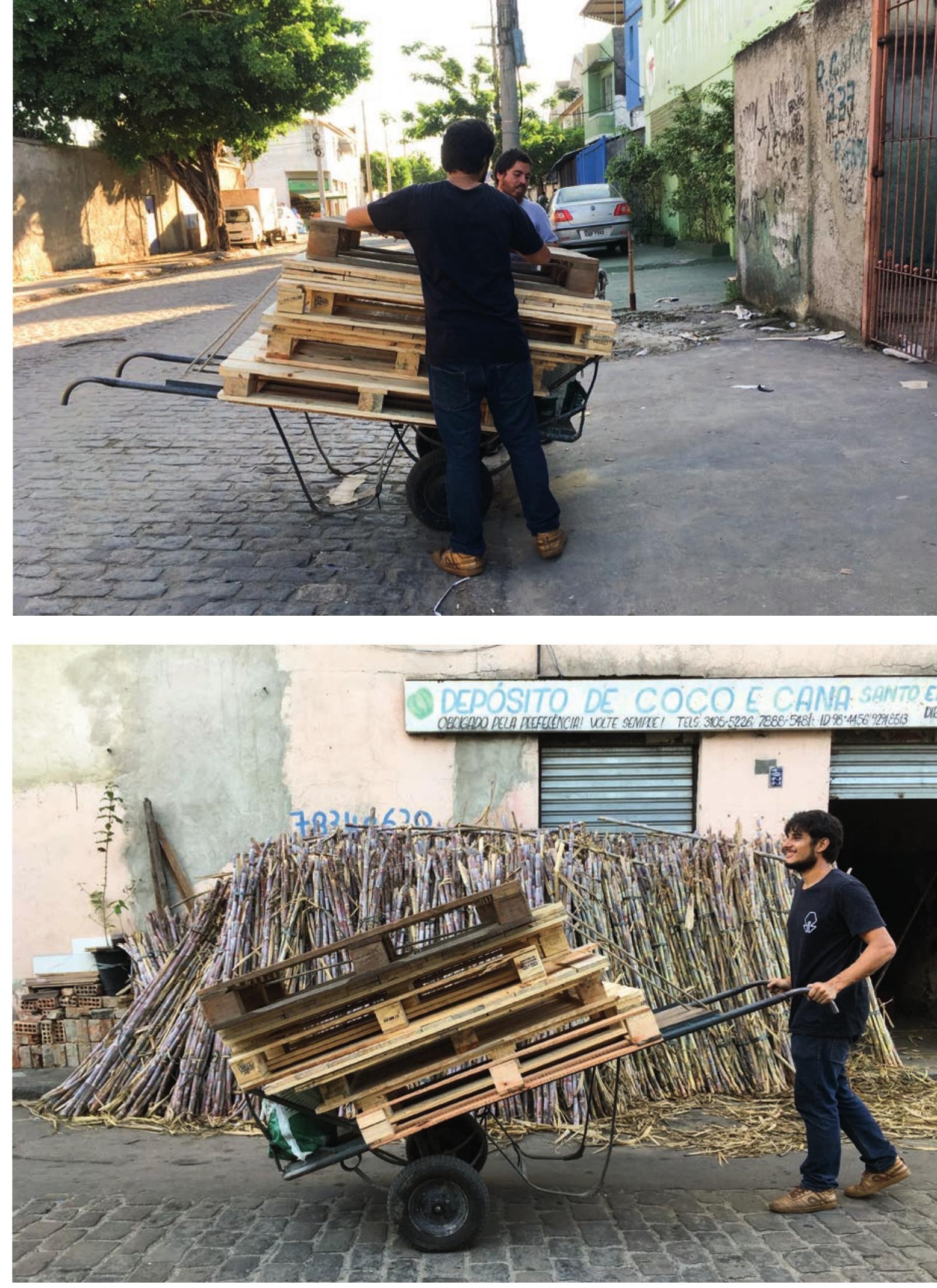

Figuras 49 e 50: Mesquita e Lopes colocando os pallets no 'burro sem rabo' (49) e Mesquita carregando o 'burro sem rabo' com pallets em cima (50). Fonte: autora da dissertação, 2017. 

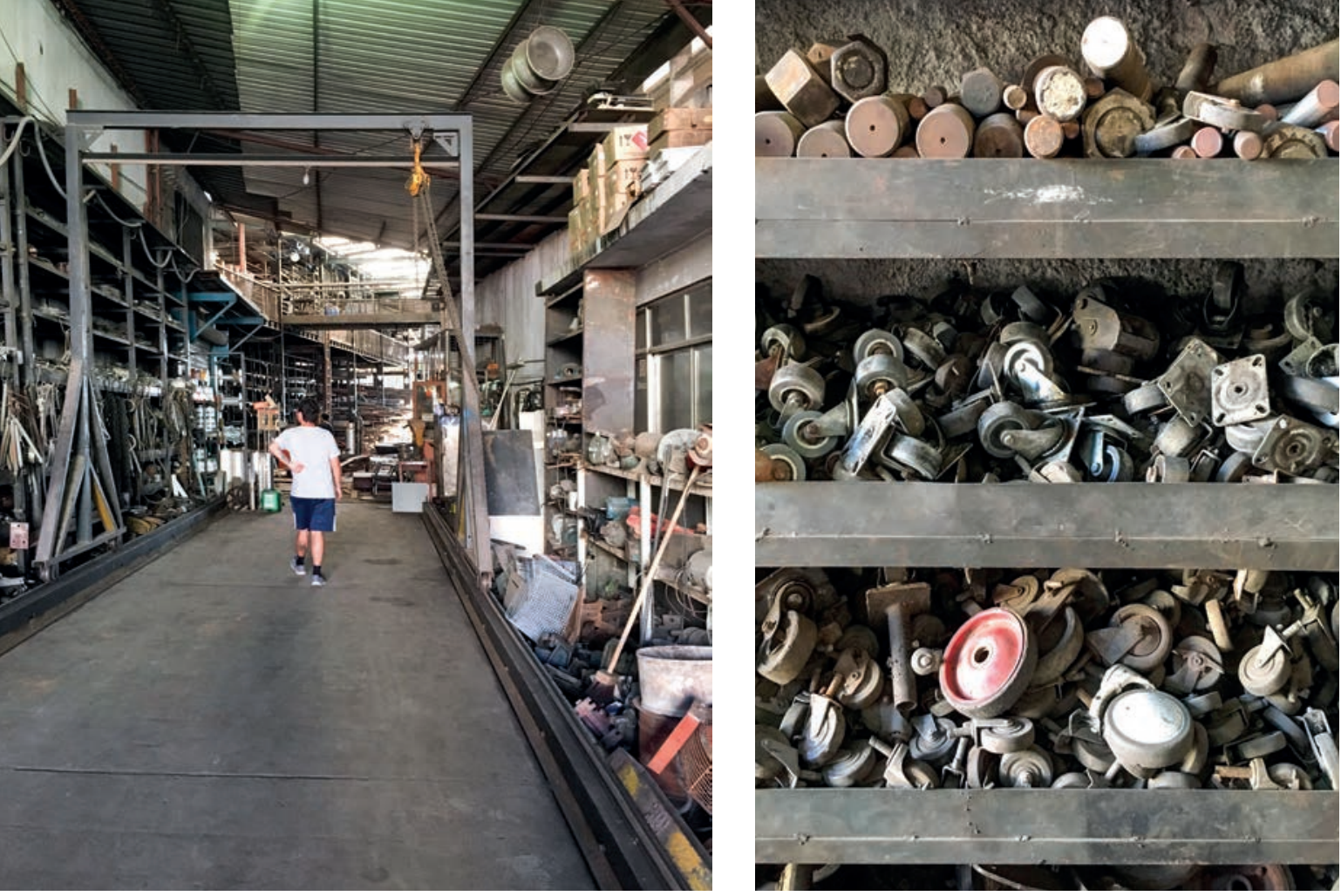

Figura 51: ferro-velho na Maré. Fonte: autora da dissertação, 2017.

dutora e distribuidora de livros didáticos, pedir doação do material. Conversamos com um funcionário extremamente gentil que nos forneceu mais de dez pallets completamente novos, que carregamos a pé até o CAM (figura 50). Um ponto interessante desta ocasião foi que conseguimos estabelecer uma parceria com o funcionário de modo que fosse possível pegar outros pallets para atividades futuras.

No caminho, com a intenção de buscarmos as caixas, encontramos um ferro-velho próximo à Rua Teixeira Ribeiro. O local era o paraíso dos materiais de construção, com muitas opções a preços econômicos de rodízios, rodas maiores, carrinhos e uma grande variedade de bugigangas (figura 51). Selecionamos uma gama de rodízios que estavam em boas condições e custavam apenas três reais, enquanto novos em lojas tradicionais custavam entre vinte e trinta reais.

Seguimos para o Observatório de Favelas, pegamos as caixas e retornamos para o CAM em tempo de realizar o terceiro dia de atividade. Ao chegarmos, alguns participantes já estavam no local, ansiosos para começar a execução manual das peças. Separamos os materiais na calçada em frente ao CAM (figura 52), buscamos alguns maquinários disponíveis na oficina do galpão Bela Maré e juntos desenvolvemos o 

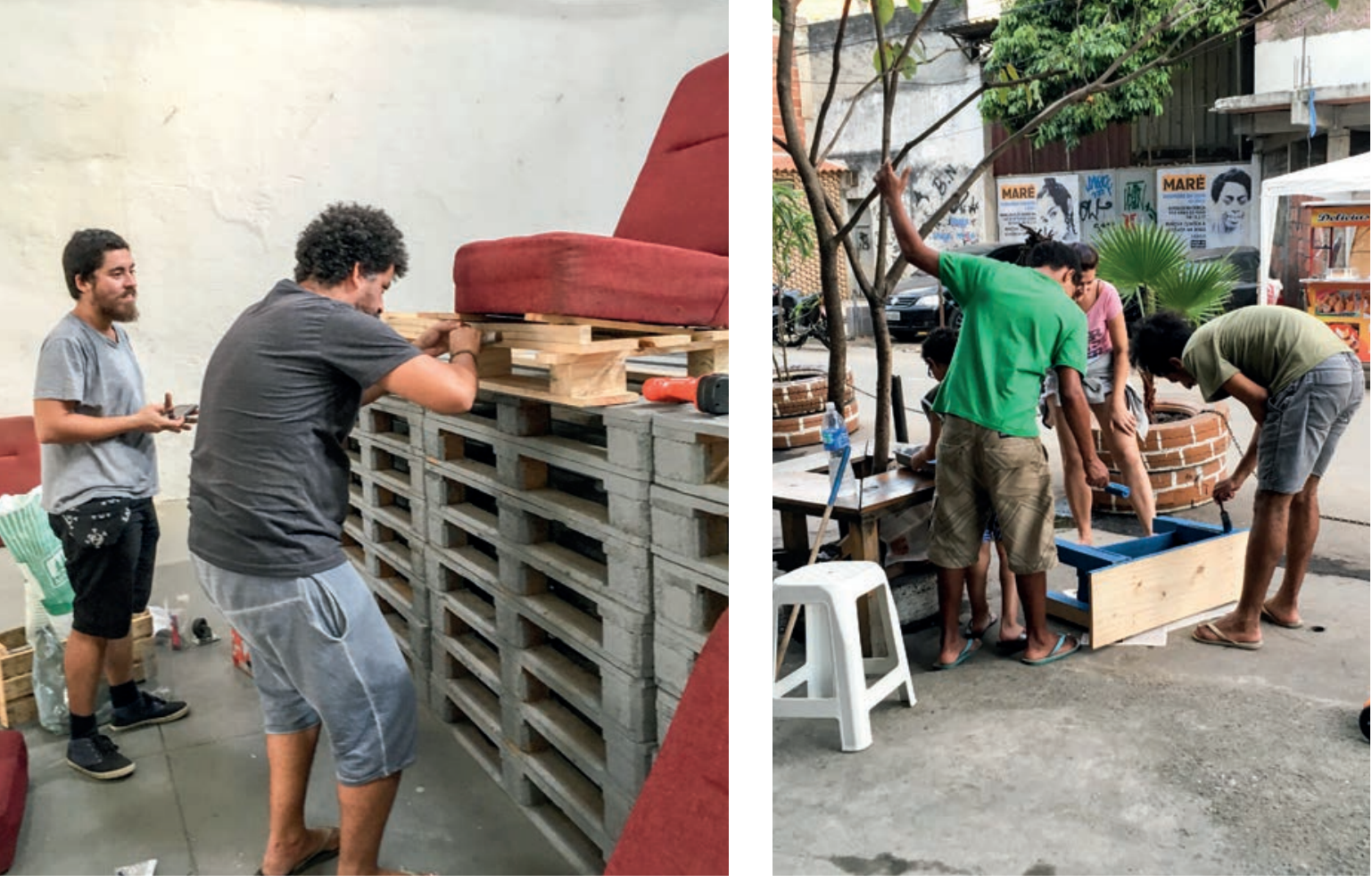

Figuras 54 e 55: Gomes e Lopes fixando o sofá itinerante (54) e participantes trabalhando juntos na pintura das peças produzidas (55). Fonte: autora da dissertação, 2017.

Após a produção das peças, documentamos o resultado final da atividade e dos objetos produzidos em diversos registros fotográficos (figuras 56, 57, 58 e 59).

\subsubsection{Reflexões e aprendizados}

Após a finalização do processo colaborativo, notei que os parceiros ficaram mais interessados na fase final de construção dos objetos e no seu resultado, enquanto as etapas iniciais de entendimento do espaço, elenco de demandas urgentes e o desenho foram os momentos em que o engajamento foi menor. Entretanto, isto pode ter ocorrido em virtude dos fatores contextuais, já que a Marcha Contra Violência era uma prioridade indiscutível naquele momento para os parceiros da Redes da Maré. Embora a proposta fosse de interesse mútuo tanto para mim quanto para os meus parceiros, os fatores contextuais ${ }^{190}$ afetaram a prática de correspondência diretamente

190. Este aspecto foi discutido por Del Gaudio (2014) em sua tese de doutorado e no artigo 'The influence of local powers on Participatory Design processes in marginalized conflict areas' com coautoria de Oliveira e Franzato (2014). Cf. Del Gaudio; Oliveira; Franzato, 2014; Del Gaudio, 2014. 
e saber reconhecer e aprender com isso foi necessário para que a troca se mantivesse viva, amadurecendo a nossa parceria e vínculo.

Entretanto, com relação àqueles que foram objetivamente para a oficina de construção-teste, foi possível perceber seu engajamento nos momentos de execução do projeto, em que se empenharam a mexer nas máquinas e materiais, tal como ocorreu durante as visitas ocasionais com as bombas de sementes feitas pelo Muda Maré. Isto me auxiliou a compreender na prática dois pontos sinalizados no tópico 3.1 deste capítulo: a relevância de orientar a prática colaborativa de design para o propósito das pessoas e a capacidade de nós designers reconhecermos a criatividade presente em todos os participantes. Ambos os pontos facilitaram o processo de codesign e permitiram a experimentação que é um elemento chave no design social participativo.

Ficou evidente que, tanto para os parceiros quanto para os participantes externos da oficina, a etapa de execução era uma prioridade em relação a de planejamento, visto que o engajamento foi maior nos momentos de produção manual. Esta observação me possibilitou perceber que as abordagens podem e devem ter etapas mescladas, adaptadas ou improvisadas de acordo com o interesse e engajamento coletivo e a reflexão espacial pode ocorrer durante a execução e construção de peças ao invés de uma roda de conversa cercada por canetas e cartolina. Somado a isso, a improvisação e as táticas foram elementos chaves, visto que permitiram que o processo não fosse enrijecido e fosse percebido como algo de execução viável para os participantes e os parceiros. Além disso, a ideia de encontrar um 'DNA da Maré também provocou reflexões em todos que pararam para pensar juntos nas características daquele espaço, seus significados, legitimando a sua existência, a sua cultura e história.

Outro ponto importante de reflexão e aprendizado foi a aceitação de que nem sempre o que esperamos do processo será o que os outros esperam, portanto, enquanto para eles o benefício estava na construção, para mim estava na minha capacidade em manter um processo que continuasse vivo. Por esta perspectiva, compreendi que se não houvesse construção, não haveria processo colaborativo, o que me evidenciou que designers devem ser flexíveis e bons ouvintes quando estão nesta posição. Esta aceitação também se reverberou quando compreendi que falar sobre design e discutir a prática era irrelevante naquele local, enquanto falar do espaço, dos usos e das 
pessoas promovia outras reações. Este aspecto também se refletiu na minha postura, visto que optei por abrir mão de mediadora no processo ao me colocar como uma pessoa inserida que também dava opiniões, participava e que ao mesmo tempo tocava a atividade junto às pessoas.

Levar estas percepções em consideração permitiu que fossem realizadas correspondências entre diferentes partes e, embora a proposição tenha focado na solução de problemas diários, isto é, demandas locais, foi possível fazer dela um processo colaborativo reflexivo e engajado. Durante a atividade, os participantes se mostraram muito interessados nos usos e na apropriação de materiais encontrados na Maré, especialmente para replicar o que aprenderam. Além disso, foi possível notar que apesar dos distintos pontos de vista, havia um interesse comum em tornar o CAM mais convidativo, agradável e inclusivo. 


\section{CAPÍTULO 4}

\section{As diferentes formas de colaboração e o desafio da co-criação}

Ao longo do processo vivenciado foi possível realizar diversas pontes entre as situações vividas e a teoria, de forma que muitas reflexões pudessem ser levantadas durante a pesquisa de mestrado. No intuito de abordar estas reflexões, este capítulo se objetiva (4.1) apresentar aspectos relevantes sobre colaboração que foram levantados no entrelaçamento entre as vivências e a literatura, (4.2) apresentar os desdobramentos após o término do processo narrado e (4.3) discutir algumas observações sobre colaboração a partir de duas entrevistas realizadas com a pesquisadora Dra. Chiara Del Gaudio. A seguir apresento cada um destes pontos e na sequência enveredo o capítulo para um fechamento da pesquisa, orientando o leitor para as considerações finais do trabalho.

\subsection{Aspectos relevantes sobre colaboração levantados na investigação}

A partir das vivências realizadas no âmbito da Redes da Maré foi possível relacionar aspectos teóricos com as situações vividas de forma que diversas reflexões fossem levantadas sobre o processo, seja em cada fase isolada ou em perspectivas gerais. O processo evidenciou que há diversas camadas possíveis para a colaboração, de maneira que esta não precisa ser lida ou interpretada apenas como uma troca em que designers e seus parceiros atuam juntos, mas por meio de vários caminhos evidenciados no processo, tal como em formas espontâneas de fazer design, na cooperação, aprendizado e táticas, no desenho coletivo e improvisação, na correspondência, na intuição e articulação, entre outras, as quais me debruço nos itens a seguir. 


\title{
4.1.1 A colaboração por meio de práticas espontâneas de design
}

Durante a primeira fase de campo, denominada 'visitas ocasionais', embora ainda estivesse conhecendo o território e os parceiros de pesquisa, os encontros me fizeram compreender como as atividades relatadas - montagem do triciclo multimídia e do jardim vertical - poderiam se configurar como práticas de design, ainda que fossem realizadas por não designers. Um ponto que me chamou atenção foi quando Lino disse: "aqui nós fazemos as coisas, nós somos fazedores" ${ }^{191}$. A ideia de que o design pode ser realizado por qualquer pessoa não é recente, já em 1964, Bernard Rudofski (Moma, 1964) realizava sua exposição 'Arquitetura Sem Arquitetos' - do inglês 'Architecture Without Architects' - a qual apresentava formas de fazer arquitetura foras dos meios modernos de construção. Na década de 1970, Nigel Cross (1972), pesquisador britânico do design, inferiu que todas as pessoas poderiam realizar práticas projetuais, ainda que não fossem formadas academicamente, já que a habilidade do fazer é inerente ao nosso modo de agir como seres humanos.

Esta concepção pode ser explorada também por meio do termo 'vernacular', que originado do substantivo masculino 'vernáculo', representa proveniência de um lugar próprio, uma região ou país, segundo o dicionário Michaelis (2018). Já para Escobar (2016, p. 56), as formas de fazer vernaculares nos dias de hoje

\begin{abstract}
já não indicam um tradicionalismo rígido, mas sim um espaço de possibilidades que poderia articular-se a projetos criativos que integram formas vernáculas, lugares, paisagens concretas, restauração ecológica e tecnologias ambientais e digitais para fazer frente a problemas graves de sustento, ao mesmo tempo que revigoram as comunidades.
\end{abstract}

Desta forma, a apropriação espontânea do espaço exercita o processo inventivo e a improvisação, que acabam por subverter os usos e a relação com o ambiente, promovendo novos significados, o reuso de objetos e novas formas de pertencimento. "As formas vernáculas de projeto também podem ser particularmente relevantes quando participam em projetos de desenho destinados a fortalecer a autonomia comunitária 
e a resiliência"192. Seguindo as palavras de Escobar, devemos ampliar nosso reconhecimento no campo sobre a existência de formas projetuais vernaculares, ou o design vernacular, que na definição da pesquisadora Fernanda Cardoso (2010, p. 12) se apresenta como "um campo de produção informal que representa a produção de indivíduos pertencentes às classes populares".

Outra perspectiva em relação às práticas vernaculares foi explorada por Maria Cecilia Loschiavo dos Santos (2003), que sugere o termo 'design espontâneo' ao investigar as habitações autoconstruídas por moradores em situação de rua nas cidades de São Paulo, Tóquio e Los Angeles a partir da improvisação com materiais como papelão e plástico. Partindo de noções como a bricolagem, o reuso e a reciclagem, a autora ${ }^{193}$ afirma que o design espontâneo pode ser entendido como "uma prática de resistência criativa de procurar soluções engenhosas aplicáveis à resolução de problemas concretos, num contexto de severa falta de recursos".

Mais recentemente, estas ideias vêm sido trabalhadas em dimensões práticas por meio de exposições, tal como o 'Design da Favela'194 (2012), que apresentou o design espontâneo nascido nas favelas do Rio de Janeiro, onde a falta de recursos estimulou a criatividade na busca de soluções. Além dessas, as exposições Uneven Growth ${ }^{195}$ (Gadanho, 2013), Handmade Urbanism ${ }^{196}$ (Rosa, 2013), a X Bienal de Arquitetura de São Paulo de $2013^{197}$ e a 11를 Bienal de Arquitetura de São Paulo de $2017^{198}$ também

192. Escobar, 2016, loc. cit.

193. Ibid., p. 75.

194. SAINT-CLAIR, R.; WESTIN, R., O Design da Favela: exposição. Centro Carioca de Design: Rio de Janeiro, 2012.

195. Uneven Growth - Tactical Urbanism for Expanding Megacities (2013) foi uma exposição do MoMa de Nova de Iorque, sobre o tema urbanismo tático, isto é, intervenções urbanas bottom-up que buscam transformar a cidade deixando-a mais habitável e participativa.

196. Handmade Urbanism (2013), ou Urbanismo Feito a Mão, é um livro, também realizado em duas exposições, que compõe iniciativas locais mapeadas e premiadas nas 5 primeiras edições d o prêmio Deutsche Bank Urban Age Award. Esta compilação retrata o trabalho das iniciativas vencedoras, seus contextos e impactos.

197. X Bienal de Arquitetura de São Paulo. Página oficial do evento. Disponível em: < https://www. facebook.com/xbienaldearquitetura/>. Acesso em: 10 Nov. 2016.

198. 11 Bienal de Arquitetura de São Paulo. Página oficial do evento. Disponível em: <https://www. 11bienaldearquitetura.org.br/>. Acesso em 28 de Nov. 2017. 
forneceram reflexões profundas sobre a vida coletiva nos espaços partilhados e o desenho urbano informal199, ressaltando a importância dos modos de fazer, usar e colaborar na cidade.

Além desses, ressalto três trabalhos envolvidos diretamente ao assunto: a dissertação 'Design por Não Designers', de Maria Cristina Ibarra (2014), que criou uma inter-relação entre a produção de artefatos urbanos por citadinos na cidade de Belo Horizonte; a tese 'Fundamentos da Gambiarra' de Rodrigo Boufleur (2013), que se apropria do neologismo brasileiro 'gambiarra' para discutir as formas de inventividade e transformação de objetos por meio do reuso e da ressignificação em experiências cotidianas; e a dissertação 'Rua dos Inventos', de Gabriela Gusmão (2003), que traz a improvisação de diferentes formas a fim de denominar a inventividade de novos objetos a partir de outros abandonados.

É interessante notar como os modos de usar e transformar espaços e objetos, quando praticados em espaços coletivos, inventam técnicas e criam artifícios, não apenas para deixá-los mais habitáveis e convidativos, mas para dar abertura a debates públicos e questionamentos sobre a realidade social, contribuindo no fortalecimento da relação de pertencimento e a identidade com o local (Rosa, 2015, p. 144-205) ${ }^{200}$. Como retratado, os dois eventos foram realizados com o objetivo de trazer experiências culturais, educacionais e lúdicas para moradores da Maré. As situações apresentadas, por mais simples que fossem, descrevem oportunidades não só para aprendizagem, mas para visualizar a capacidade propositiva e criativa existentente nesses contextos através de etapas projetuais como o planejamento, a geração de ideias e a experimentação.

Como observado nos casos narrados, cada uma das ações realizadas pelos parceiros esboçam traços espontâneos de design por não designers configurando outra forma de colaboração, visto que exercitam o fazer e a experimentação como meios para reflexão, contribuindo para outros olhares e percepções que às vezes não são eviden-

199. Refiro-me aqui a informal toda e qualquer tipo de instância não suportada por uma ordem de autoridade, uma instituição ou o poder público.

200. Recomendo a leitura do terceiro capítulo da tese de Marcos Rosa (2015, p. 144-205) que aborda sobre a magnitude do fazer coletivo e as dimensões de participação através de uma leitura urbana e espacial ao longo do tempo e permite uma compreensão de maior profundidade no assunto em questão. 
tes, estão internalizados ou não são reconhecidos de imediato, caso das fronteiras por exemplo. Em ambos os casos, o fazer, a criatividade e o processo lúdico se mostraram como caminhos para colocar questões a público, discutir as urgências locais e promover a colaboração entre diversos atores almejando um propósito comum.

Essas práticas já realizadas por não designers poderiam ser abarcadas em processos com designers possibilitando uma colaboração respaldada nas habilidades e vocações locais, nas questões de interesse já identificadas e nas particularidades do contexto. Por este caminho, práticas isoladas e desconexas com o contexto poderiam ser evitadas, possibilitando processos mais ricos e compartilhados.

\subsubsection{A colaboração por meio da cooperação, do aprendizado e das táticas}

Ainda na primeira fase de observação participante, foi possível observar que a colaboração só foi possível a partir de algumas concepções teóricas que contribuíram para a minha análise: os rituais de cooperação e o aprendizado colaborativo, de Richard Sennett (2013a; 2013b), as táticas, de Michel De Certeau (2014) e as formas de improvisação, abordadas por Tim Ingold e Elizabeth Hallam (2007). Esta última é citada ao final com a intenção de criar um paralelo entre a improvisação e as concepções teóricas anteriores.

Já abordadas anteriormente, as 'táticas' podem ser encontradas no livro 'A Invenção do Cotidiano: Artes de Fazer' de Michel De Certeau (2014). Para o autor ${ }^{201}$, as táticas definem formas de ação que ocorrem sem planejamento, espontaneamente, de forma não calculada, escapando das agendas institucionais que manipulam constantemente eventos, espaços e coisas, transformando-os em "oportunidades", de maneira que o planejamento ou o desenho pré-concebido e prescrito é subvertido por outra forma de ação.

No contexto das atividades acompanhadas, as táticas são onipresentes. A maneira como se lida com objetos, ferramentas e espaços, dando outros usos a eles, não da forma como foram produzidos, qualificam seus atos como táticas. No exemplo da experiência do triciclo multimídia, foi utilizado um objeto produzido inicialmente por indústrias como uma bicicleta de carga para entregar produtos e não como um veí- 
Nas atividades acompanhadas, foi possível ver que os jovens desenvolviam suas habilidades apenas observando e escutando outros que detinham conhecimento, como o caso de Renan Braga e Sarah Alves ao ensinar sobre o manuseio com as peças de bicicletas. Notei também que em diferentes ocasiões, as crianças queriam participar, mas não sabiam como usar ferramentas, como na situação em que construímos os jardins verticais. $\mathrm{O}$ aprendizado colaborativo, neste caso, ocorreu por meio da atuação de integrantes do Muda Maré ao convidá-los para participar mais de perto, deixando-os aprender enquanto faziam, assim como sucedeu na atividade de bombas de sementes. No início, os jovens não estavam interessados, mas depois que viram a oportunidade de executar concretamente, se envolveram na atividade de maneira colaborativa.

A terceira e última concepção teórica, os "rituais de cooperação" situados na obra 'Together' - em português 'Juntos' - também de Richard Sennett (2013b), explora a cooperação em diferentes contextos, incluindo no âmbito comunitário. De um lado temos a cooperação que nas palavras do autor ${ }^{203}$ pode ser definida como

$$
\begin{aligned}
& \text { uma troca em que os participantes se beneficiam do encontro. Este } \\
& \text { comportamento é instantaneamente reconhecível em chimpanzés, } \\
& \text { preparando um outro, crianças construindo um castelo de areia, ou } \\
& \text { homens e mulheres que colocam sacos de areia contra uma inundação } \\
& \text { iminente. Instantaneamente reconhecível, porque o apoio mútuo é } \\
& \text { incorporado aos genes de todos os animais sociais; Eles cooperam para } \\
& \text { realizar o que não podem fazer sozinhos. }{ }^{204}
\end{aligned}
$$

Do outro há os rituais, que para o autor ${ }^{205}$ podem "dar forma a trocas informais de ganha-ganha; (...) [e] possibilitam que as coalizões com parceiros fortes e fracos trabalhem em conjunto para seu benefício comum"206, ao mesmo tempo transformam

203. Ibid., p. 5, tradução nossa.

204. Sennett, 2013b, p. 5. No original: "as an exchange in which the participants benefit from the encounter. This behaviour is instantly recognizable in chimpanzees grooming one other, children building a sandcastle, or men and women laying sandbags against an impending flood. Instantly recognizable, because mutual support is built into the genes of all social animals; they cooperate to accomplish what they can't do alone".

205. Ibid., p. 94, tradução nossa.

206. No original: ritual can give a shape to informal win-win exchanges; moreover, face-saving rituals make it possible for coalitions with strong and weak partners to work together for their common benefit". 
“objetos, movimentos corporais ou palavras amigáveis em símbolos ${ }^{207}$, ganhando intensidade de acordo com a sua repetição. $O$ encontro entre os rituais e a cooperação emerge em práticas coletivas que se repetem ao longo do tempo, como a prática do ensaio entre músicos ou artistas em que deve ocorrer uma sincronia na atuação que exige que profissionais devam ensaiar, praticar e entender a posição do outro para executar as suas próprias ações. No entanto, um ponto interessante colocado pelo autor é que "ao contrário das práticas de atuação de músicos ou atores profissionais, os rituais diários devem ser acessíveis e fáceis de aprender, para que todos possam participar”208.

Os rituais de cooperação estão presentes no âmbito das atividades observadas em vários aspectos, ora na capacidade dos grupos envolvidos se ajudarem para executar uma ação nos espaços utilizados, ora na continuidade de atividades envolvendo mobilidade, que estimulam continuamente a participação de crianças e jovens, ampliando seu repertório acerca da influência das fronteiras. Além disso, a noção de que os rituais devem ser fáceis de aprender e inclusivos é instantaneamente atendida quando o aprendizado colaborativo é colocado em prática na atitude de 'aprender fazendo'. Os rituais de cooperação ocorrem a todo o momento formando nós na malha da vida social (Ingold, 2012), promovendo novos encontros, novos aprendizados e evoluindo continuamente, como o encontro entre vários grupos na Praça do Parque União com a chegada do triciclo multimídia, ou no ritual do passeio ciclístico coletivo que no momento em que várias pessoas se juntam num objetivo comum, novos símbolos são formados, como a ideia de que uma nova Maré é possível, uma Maré sem fronteiras.

É interessante notar que as três concepções teóricas se alinham diretamente com a noção de improvisação de Ingold e Hallam (2007), nas quais a improvisação pode ser vista em cada uma delas. Para os autores ${ }^{209}$ a improvisação pode ser compreendida em três vieses diferentes:

\footnotetext{
207. Ibid., p. 91, tradução nossa. No original: "transform objects, bodily movements or bland words into symbols".

208. Ibid., p. 92. No original: "Unlike the performing practices of professional musicians or actors, everyday rituals have to be accessible and easy to learn, so that everyone can participate".

209. Ibid., p. 1, tradução nossa.
} 
- Gerador, "no sentido de que dá origem aos fenômenos culturais, como são experimentados por aqueles que vivem deles ou de acordo com eles" ${ }^{210}$, tal qual o aprendizado é passado de mãos em mãos;

- Relacional, "na medida em que está continuamente sintonizado e receptivo a performance dos outros"211, tal qual os rituais de cooperação existem para alcançar algo impossível individualmente;

\section{QUADRO DE CONCEITOS ANÁLOGOS}

Noções de improvisação de Ingold and Hallam (2007, p. 1) em comparação com os conceitos de tática de De Certeau (2014, p. xix), 'aprendizados colaborativos' e "modos de cooperar" de Richard Sennett (2009, p.10-181; 2013, p.29-42).

A IMPROVISAÇÃO É GERADORA

"Dá origem às formas fenomenais de cultura vivenciadas por aqueles que as vivem ou de acordo com elas"

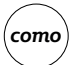

$($ como

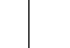

\section{APRENDIZADO COLABORATIVO}

"O uso de ferramentas imperfeitas ou incompletas desenha a imaginação no desenvolvimento de habilidades para reparar e improvisar (...). Aprender com demonstração coloca o ônus sobre o aprendiz; assume ainda que a imitação direta pode ocorrer."
A IMPROVISAÇÃO É RELACIONAL

"Está continuamente sintonizado e receptivo ao desempenho dos outros"

\section{RITUAIS DE COPERAÇÃO}

"Uma troca em que os participantes se beneficiam do encontro (...) porque o apoio mútuo é incorporado aos genes de todos os animais sociais; eles cooperam para realizar o que não podem fazer sozinhos"

\section{A IMPROVISAÇÃO É TEMPORAL}

"Não pode ser colapsado em um instante, ou mesmo uma série de instantes, mas incorpora uma certa duração"

\section{como TÁTICAS}

"Manipula constantemente eventos para transformá-los em 'oportunidades' (...) alcançadas nos momentos propícios quando conseguem combinar elementos heterogêneos"

Quadro 1: conceitos análogos e suas definições. Fonte: desenvolvido pela autora. Fonte: autora da dissertação, 2017.

$+++++++++++++++++++++++++++++++++++++++++++++++++++++++++++++++++++++++++++++++++++++$

210. No original: "in the sense that it gives rise to the phenomenal forms of culture as experienced by those who live by them or in accord with them" (Ingold; Hallam, 2007, p. 1).

211. Idem. No original: "in that it is continually attuned and responsive to the performance of others". 
- Temporal, "que significa que não pode ser colapsado em um instante, ou mesmo uma série de instantes, mas incorpora uma certa duração" ${ }^{212}$, tal qual as táticas que ocorrem em oportunidades específicas e brechas encontradas no tempo e no espaço.

No quadro (1) a seguir é possível observar estas relações entre conceitos, evidenciada a partir da observação de atividades colaborativas no território da Maré:

Tanto a improvisação e seus três vieses, quanto os rituais de cooperação, o aprendizado colaborativo e as táticas são aspectos presentes da realidade do Complexo da Maré, e por meio desses, o grupo se articula e desenvolve atividades engajadoras e de dimensão pública, ainda que com poucos recursos e pouca infraestrutura. Através das lentes observadas foi possível compreender com uma maior profundidade a complexidade das ações coletivas ali realizadas, evidenciando as potencialidades locais e a vocação comunitária (Sennett, 2013b) do grupo, isto é, a arte, a cultura e a sustentabilidade como meios de aprendizado e colaboração.

\subsubsection{A colaboração por meio do desenho coletivo e da improvisação}

Pensar cada um dos atos realizados como uma prática espontânea de design ou como uma forma de improvisação também me possibilitou perceber que não há um olhar direcionado do grupo apenas para o resultado dos objetos construídos, mas um foco na experiência do fazer coletivo, em que o processo de aprendizado é um quesito tão relevante quanto o resultado do ambiente construído. Esta percepção foi um aprendizado para pensar o processo de fazer design coletivamente, na mesma ideia sugerida por Bruno Latour (2009) de "desenhar coisas juntos"213. Mais do que ter objetos prontos, fatos consumados na visão Latouriana, os grupos estavam preocupados com o processo transformativo daquelas coisas e como elas proporcionariam aprendizado e criatividade aos participantes, de maneira que iam se transformando conforme eram montados coletivamente, fosse um triciclo multimídia, um jardim vertical ou uma bicicleta montada do zero.

\footnotetext{
212. Idem. No original: "meaning that it cannot be collapsed into an instant, or even a series of instants, but embodies a certain duration".

213. No original: "drawing things together".
} 
A ideia de construir junto e repensar os objetos como coisas ocorria ali naturalmente, afinal, porque não comprar um jardim vertical pronto, por exemplo? Latour ${ }^{214}$ sugere que a materialidade modernista internalizada em nossa cultura ganha sua concretude a partir de questões de fato - do inglês matters of fact - que tiveram sua estética "historicamente situada, uma maneira de iluminar objetos, enquadrá-los, apresentá-los, situar o olhar dos espectadores, projetar os interiores em que são apresentados - e claro, a política com a qual eles estão (estiveram) tão fortemente associados ${ }^{215}$." Oposta a esta visão, o autor sugere que migremos das questões de fato, objetivas e terminantes, em questões de interesse - do inglês matters of concern -, que em seu idioma "reivindica matéria, questões e materialidades e as torna em algo que pode e deve ser cuidadosamente redesenhado" ${ }^{216}$.

Observando os processos de ação coletiva e as trocas proporcionadas, notei que o grupo focava em questões de interesse a todo o momento. "Como podemos desenhar juntos questões de interesse para oferecer às disputas políticas uma visão geral, ou ao menos uma visão, das dificuldades que nos envolvem sempre que precisamos modificar os detalhes práticos da nossa existência material?"217. Ao pensar a constante discussão das fronteiras no território por meio da construção coletiva de coisas, a pergunta de Latour era respondida.

Além disso, pensar a improvisação como um meio de realizar a prática de design, tal qual feita por não designers no contexto descrito, me possibilitou assimilar a ideia proposta por Ingold e Caroline Gatt (in Gunn et al., 2013, p. 145, tradução nossa) de que o "design não é tanto sobre a inovação quanto é sobre a improvisação" ${ }^{218}$. Para os

214. Ibid., p. 9 .

215. No original: a historically situated aesthetics, a way to light objects, to frame them, to present them, to situate the gaze of the viewers, to design the interiors in which they are presented - and of course the politics with which they are (they were) so strongly associated.

216. Ibid., p 11. No original: "The idiom of matters of concern reclaims matter, matters and materiality and renders them into something that can and must be carefully redesigned".

217. Ibid., p. 12. No original: "How can we draw together matters of concern so as to offer to political disputes an overview, or at least the view, of the difficulties that will entangle us every time we must modify the practical details of our material existence?"

218. No original: "design is not so much about innovation as about improvisation". 
autores ${ }^{219}$, reconhecer a improvisação como um meio para a prática, significa reconhecer "que a criatividade do design é encontrada não na novidade de soluções prefiguradas para problemas ambientais percebidos, mas na capacidade de habitantes para responder com precisão às circunstâncias de mudanças constantes em suas vidas"220.

Somado a isso, a improvisação pode ser interpretada para os autores como um caminho para atingir a ideia de foresight - palavra inglesa que não possui uma tradução direta para o português, mas pode ser entendida por 'previsão'. Para Ingold (in Gunn; Donovan, 2012, p. 27) "prever é ver o futuro, não projetar um futuro estado de coisas no presente; é olhar para onde você está indo, não para consertar um ponto final. Essa previsão é sobre profecia, não previsão. E é o que permite que os praticantes continuem"221. De forma complementar, os autores ${ }^{222}$ descrevem que

Prever, no entanto, é correr à frente das coisas e puxá-las para trás, ao invés de projetar por uma extrapolação do presente. Procurando não especular sobre, mas ver o futuro, é improvisar uma passagem ao invés de inovar com representações do inédito. (...) é sobre abrir caminhos ao invés de estabelecer alvos; sobre antecipação, não predeterminação. Mais importante, a previsão envolve a imaginação. ${ }^{223}$

Ao reconhecer a capacidade de previsão ou 'foresight' situada por Ingold e Gatt ${ }^{224}$ nas atividades observadas, compreendi como esta deveria ser implementada na minha própria postura como designer naquele espaço. Entretanto, compreender as táticas e as improvisações locais me exigiria uma imersão mais profunda no cotidiano da-

219. Idem, tradução nossa.

220. No original: "recognize that the creativity of design is found not in the novelty of prefigured solutions to perceived environmental problems but in the capacity of inhabitantes to respond with precision to the ever-changing circumstances of their lives".

221. No original: "to foresee, (...), is to see into the future, not to project a future state of affairs in the present; it is to look where you are going, not to fix an end-point. Such foresight is about prophecy, not prediction. And it is what enables practitioners to carry on".

222. Ingold; Gatt in Gunn et al., 2013, op. cit., tradução nossa.

223. No original: "To foresee, however, is to run ahead of things and to pull them along behind you, rather than to project by an extrapolation from the present. Seeking not to speculate about but to see into the future, it is to improvise a passage rather than to innovate with representations of the unprecedented. (...) it is about opening up pathways rather than setting targets; about anticipation, not predetermination. Most important, foresight involves imagination".. 
quele espaço e daquelas pessoas, de modo que fosse possível perceber as entrelinhas das atividades colaborativas de forma que eu me metesse dentro delas. Ainda que o resultado da pesquisa não engendrasse um processo colaborativo em que eu aplicasse técnicas do design ou desenvolvesse algum projeto com eles, seria possível promover experimentações colaborativas baseadas nas questões de interesses locais?

Para todos os efeitos, eu possuía uma certeza ao final das visitas ocasionais: qualquer atividade colaborativa que envolvesse experimentação, reflexão, desenvolvimento de coisas e assim por diante, só ocorreria se eu fizesse um mergulho naquele ambiente, no seu dia-a-dia e entendesse com maior profundidade as relações. Em razão disso, realizei a segunda fase de pesquisa no local acompanhando as atividades cotidianas a partir da minha parceria com Lino e Lopes.

\subsubsection{A colaboração por meio da correspondência}

Ao longo do período de imersão, inúmeras observações foram realizadas engendrando reflexões acerca do campo investigado, isto é, o âmbito da Redes da Maré e a própria favela da Maré, as quais dividi em três vieses: (a) aspectos de ordem cultural; (b) aspectos de ordem espacial; (c) aspectos de ordem propositiva. Estas observações foram imprescindíveis para pensar a colaboração no local e a possibilidade de ação com os parceiros, sucedida na fase (3.4) 'Da observação para ação', visto que me forneceram uma compreensão mais aprofundada daquelas levantadas nas visitas ocasionais.

Com relação aos (a) aspectos de ordem cultural, foi possível notar que o imediatismo e a necessidade de resolver problemas em curto prazo são práticas comuns em virtude do cotidiano da Maré, dificultando a realização de atividades processuais e em longo prazo, desafio constante no trabalho de colaboradores da Redes da Maré, que ainda assim, promovem qualidade de vida ao território. Somado a isso, há um alto número de demandas complexas, evidenciadas constantemente por Lino e outros colaboradores, como manutenção e reparação dos espaços, questões com moradores em situação de rua, confrontos e a violência cotidiana, dificuldade de engajamento de crianças e jovens, grande quantidade de mães muito jovens, crianças com pouco suporte fa- 
miliar, entre outros que me certificavam que o design não resolveria os problemas complexos daquele contexto.

Outro ponto foi o ritmo de vida, já que este ocorre em outro tempo, não necessariamente cronológico, mas de acordo com as dinâmicas espaciais. Só em 2017 foram quase vinte dias sem aulas para crianças e jovens por conta de disputas entre grupos armados, o que imobilizou muitas famílias. Além disso, a lógica produtivista da 'cidade formal' não chega à Maré da mesma forma, o que faz com que haja muitas pessoas desocupadas ou sem rumo, especialmente nas favelas com menores índices de desenvolvimento, como a Nova Maré.

Somado a estes, há também o aspecto da acumulação, presente por todo o território, por meio de materiais obsoletos, de armazenamentos sem utilidade e da grande quantidade de lixo, muitas vezes não coletado pela dificuldade de entrada da Comlurb no local. A cultura da acumulação possui um lado que torna seus espaços com aspecto desordenado, porém possibilita que moradores da Maré criem, transformem e inventem o espaço com poucos recursos e, muitas vezes, por meio do reuso, promovendo uma cultura do fazer que há anos é facilmente dominada.

Os (b) aspectos de ordem espacial foram percebidos em vários sentidos. Um deles está nas relações institucionais da Redes da Maré e a busca por autonomia de vários colaboradores, propiciando que amarras institucionais sejam constantemente flexibilizadas pelo território, permitindo outras formas de ocupação de caráter efêmero. Esta troca entre organização institucional e autonomia para fazer coisas foi percebida inúmeras vezes, em diferentes atividades, de modo que fosse possível notar uma relação dialética entre as partes, como mencionado no capítulo dois sobre a relação entre Coletivo Maré e Redes da Maré, consequentemente gerando um maior envolvimento em mais espaços do território como praças, parques, quadras e outros.

Além disso, foi possível notar aspectos de resistência, resiliência e disputa espacial constantes, vistas entre transeuntes, veículos (bicicletas, motos e alguns carros), a presença de grupos armados, a criação de espaços de lazer infantil, como camas elásticas, pula-pula inflável e piscinas montáveis nas ruas, festas infantis e muitas outras formas de apropriação espacial que aconteciam simultaneamente. Ficou evidente a 
luta contínua contra a violência, marcada por inúmeras invasões policiais ao território, disputas de facções criminosas entre si e a polícia e outros aspectos que impedem que os moradores da Maré possam viver com um pouco mais de tranquilidade como outros cidadãos da cidade do Rio de Janeiro.

No que se relaciona aos (c) aspectos de ordem propositiva, me refiro tanto ao modo de agir do grupo, quanto o meu como pesquisadora em campo. Pude compreender como a equipe da Redes da Maré é completamente ativa, realizando diversos projetos, atividades e eventos em seus múltiplos espaços. A capilaridade existente na ação do grupo permite que ele trabalhe em diversas frentes, que vão do cenário de usuários de craque na Rua Flávia Farnese até a realização de desfiles e espetáculos culturais brasileiros, como o ‘Tambores de Olokun' nas ruas da Maré e o 'Obinrin - Ventos na Maré' no CAM.

Embora haja uma riqueza imensa e grande quantidade de questões para trabalhar, enxerguei a minha capacidade projetual um pouco desorientada, visto que tive uma grande dificuldade de encontrar espaço para aplicar as abordagens que havia carregado comigo no cotidiano da organização. Realizar um processo de design colaborativo como os tradicionalmente vistos no âmbito corporativo não fazia qualquer sentido e em muitos momentos tive dúvidas relativas ao modo como poderia realmente colaborar como uma profissional do design.

Levando em conta o ritmo de vida local, foi possível compreender na leitura dos pesquisadores Del Gaudio, Franzato e Oliveira (2016, p. 4), que o tempo é um ponto crucial em processos colaborativos em territórios como o da Maré. Na perspectiva dos autores ${ }^{225}$, "uma situação de inadaptação temporal é uma circunstância comum quando este tipo de projeto é desenvolvido e geralmente tem um impacto negativo. Produz problemas de colaboração e sincronização porque a percepção do tempo e as fases das ações e a velocidade de implementação diferem" ${ }^{\prime 226}$. Trata-se não apenas de compreender as diferentes temporalidades dos atores envolvidos, mas as possibilidades de encontros nas diferenças existentes, tal como situa Haraway (2016).

225. Ibid., p. 4.

226. No original: "a situation of temporal misfit is a common circumstance when this type of project is developed and it usually has a negative impact. It produces collaboration and synchronization problems because time perception and the actions' phases and implementation speed differ". 
Pensar o tempo como um ator não humano no processo e a sua percepção distinta de acordo com os diferentes pontos de vista também foi uma reflexão relevante no processo. Em determinado momento foi necessário deixar o tempo daquele lugar orientar a minha atitude, evitando imposições, permitindo que a colaboração emergisse a partir da interação e das questões de interesse dos parceiros. Esta atitude foi também observada por Rita Couto (1991), em sua dissertação de mestrado, quando se debruçou sobre a abordagem de design social participativo. Ao definir conceitualmente a abordagem a partir de depoimentos do professor José Luiz Mendes Ripper, Couto ${ }^{227}$ enfatiza que devemos priorizar "a lógica do usuário e não a lógica dos meios de produção" e afirma que

(...) em projetos sob o enfoque do Design Social, a inovação consiste em introduzir em praticamente todas as etapas do processo de projeto, que objetiva produtos práticos, a participação efetiva de elementos da população alvo, ou seja, dos futuros usuários do produto. Com esta prática, o Design Social procura contornar a situação da população de usuários marginalizada em relação aos produtos a elas dirigidos.

Apesar de ter colaborado inúmeras vezes por meio do desenvolvimento de peças gráficas, cartazes e impressos, ainda me deparava com uma associação comum ao design como ferramenta para a prestação de serviços e não como um ator colaborador nos processos diários. Foi possível perceber por estas experiências como o design ainda é muito elitizado e associado diretamente a uma prática solucionadora de problemas, fato que me evidenciou a necessidade de abertura e democratização do campo ao mesmo tempo.

Outro ponto complexo desta fase foi a constante solidão como pesquisadora em cam$\mathrm{po}^{228}$, visto que era a única designer naquele local ambicionando praticar processos colaborativos. Além disso, esta dificuldade também se deu por conta da a pouca quantidade de pesquisadores envolvidos em ambientes complexos, a dificuldade para conquistar a minha própria autonomia, a falta de recursos para o desenvolvimento de processos colaborativos mais estruturados e, por fim, a dificuldade de aplicar abordagens participativas sem impor uma prática que partisse somente da minha vontade e intenção.

\footnotetext{
227. Ibid., p. 15.
}

228. Assuntos como este são também tratados na publicação Urbanxchanger (Rosa; Weiland, 2017), que apresentam ideias relevantes sobre o que de fato é a colaboração na prática de design, seus desafios e dificuldades, muitas veze ignorados, visto que o resultado é o foco principal. 
A partir destas reflexões, foi possível compreender o solo em que eu pisava e como poderiam ser as relações nestas perspectivas. Por este caminho, me apoiei na correspondência (Ingold, 2016), como citado no capítulo anterior. Por meio da correspondência foi possível negociar com os parceiros e chegar a um ponto comum. Lino me pediu para construir uma estante e eu questionei o seu pedido a fim de proporcionar uma negociação e fazê-la refletir sobre o espaço junto comigo. Neste diálogo chegamos ao que Ingold ${ }^{229}$ coloca como "o processo pelo qual seres ou coisas literalmente respondem uns aos outros ao longo do tempo, por exemplo, na troca de cartas ou palavras em uma conversa, ou presentes, ou mesmo de mãos dadas"230, isto é, a correspondência.

O autor ${ }^{231}$ analisa a correspondência a partir de três pontos: o hábito, o agenciamento e a atencionalidade. Recorrer a correspondência através do hábito significa não impor atos ou ações, mas se deixar passar por algo, viver no hábito do outro, se sujeitar, de forma que a transformação venha de dentro. No agenciamento, assim como no hábito, a correspondência ocorre não a partir de uma ação, mas emergindo no processo, nas trocas e nas relações. Já a atencionalidade se opõe para o autor à intencionalidade. Ao invés de chegar com intenções, o antropólogo sugere a correspondência por meio de gestos atencionais, compreendendo a atenção e a escuta como práticas de cuidado entre as partes envolvidas.

A ideia de correspondência pode ser também discutida no âmbito das trocas, como abordou Marcel Mauss (2003) em sua obra "Ensaio sobre a dádiva”, na qual debruça sobre as trocas econômicas de povos da Polinésia e Melanésia. Na percepção do autor, as diferentes formas de troca, sejam elas materializáveis ou subjetivas, são legítimas, simbólicas e dialéticas, em que o dar e o receber moldam o modo como interagimos e nos relacionamos com o outro. Neste sentido, a troca realizada entre eu e Lino promoveria a possibilidade de chegarmos a um acordo comum, no qual embora aspirássemos coisas diferentes - ela, infraestrutura para o espaço e eu, um processo colaborativo de design -, chegaríamos a um termo recíproco.

229. Ibid., p. 14 .

230 No original: "the process by which beings or things literally answer to ne another over time, for example in the exchange of letters or words in conversation, or gifts, or indeed in holding hands" (Ingold, 2016, p. 14). 
Desta forma, alcançamos uma questão de interesse para trabalharmos coletivamente e, com base neste diálogo, concluímos que seria mais relevante desenvolver uma oficina que gerasse objetos para o local, de forma que estes fossem utilizados e testados, promovendo reflexões sobre as dinâmicas e demandas espaciais, em vez de apenas fornecer um objeto pronto, uma questão de fato. Assim, a correspondência seguiu o caminho pelo qual fomos capazes de promover a colaboração naquele momento, trocando questões de interesse e propiciando que um processo de design fosse realizado no Centro de Artes da Maré a fim de atender às suas demandas cotidianas.

\subsubsection{A colaboração por meio da intuição e da articulação}

À medida que chegamos a um ponto de troca viável, foi possível adotar efetivamente uma atitude propositiva junto aos parceiros da pesquisa tal qual foi narrada a terceira fase no tópico 3.4. Através desta experiência foi possível levantar muitas reflexões acerca do processo colaborativo, ainda mais diante de fatores contextuais complexos que inviabilizaram que as responsabilidades fossem melhor compartilhadas entre os atores participantes.

Ao longo do processo, durante a realização da oficina, a situação de calamidade na Maré só dificultou que realizássemos uma experiência colaborativa balanceada, na qual todos pudessem colaborar como havíamos acertado anteriormente. Em razão disso, compreendi que conceber a prática de correspondência pode ser algo laborioso quando uma das partes precisa responder às questões que estão além da nossa habilidade de resolução de problemas, como o caso de Lino e a urgência em realizar a marcha contra violência na Maré. Em virtude da influência dos fatores contextuais, também evidenciados por Del Gaudio (2014, p. 207-240) durante a sua própria pesquisa na Maré232, observei que a ideia de praticar um design que não impõe términos e

\footnotetext{
232. Embora muitas das questões de Del Gaudio tenham sido diversas das minhas, visto que trabalhamos com espaços e pessoas diferentes, a autora lidou com questões do próprio território como a violência que impedia o trânsito entre lugares, as divergências temporais entre a sua ação como designer-pesquisadora os atores do contexto e as relações de força e poder entre as partes envolvidas. Estas e outras questões foram elaboradas em seu capítulo seis "Questões para o espaço de ação do designer". Cf. Del Gaudio, 2014, p. 207-240.
} 
que é relacional e situacional consistiria em uma mudança de postura da minha parte, desempenhando a atividade de acordo com as complexidades impostas.

Em certos momentos algumas perguntas de Escobar (2016, p. 191-192, tradução nossa) soavam como se fossem minhas: "é possível pensar sobre o design sob essas condições de intensa repressão e violência?" "33 "É possível pensar um design a partir de uma vida tão profundamente relacional, processual, historicizada e aparentemente sempre em movimento e mudança em um mundo sempre em formação?"234. Optar por dar continuidade ao processo apesar das adversidades representava um gesto político, tal como coloca o autor ${ }^{235}$ quando sugere que "todo processo é político porque qualquer construção implica decisões que afetam as pessoas e os entornos em formas particulares" ${ }^{236}$.

Este aspecto pode ainda ser refletido sobre a minha postura inicial de auto convite, envolvendo a perspectiva ativista orientada a partir das questões de interesse locais. Este fato fora analisado algumas vezes, visto que assimilar as dificuldades como engajamento, adversidades contextuais, falta de recursos e estrutura deveria ser algo reconhecido como parte da proposta de ação na pesquisa, que buscou seguir sem amarras institucionais, mas focada nos interesses dos parceiros. Não se trata de aceitar todo e qualquer impasse, mas reconhecer o posicionamento em que a correspondência foi inicialmente estabelecida e de que maneiras isto também pode vir a afetar o processo. A seguinte passagem de Escobar ${ }^{237}$ elucida de forma simplificada esta reflexão:

Tanto a atividade reveladora quanto o fazer das rupturas implicam ir além da idéia comumente aceita de que o mundo funciona em términos de representações mentais individuais de um 'problema'; ao contrário, avançam para uma perspectiva de interações sociais modeladas

233. No original: “Es posible pensar en el diseño bajo estas condiciones de intensa represión y violencia?”. 234. Ibid., p. 106, tradução nossa. No original: “¿Es posible pensar en el ‘diseño’ desde una vida tan profundamente relacional, procesual, historizada y aparentemente siempre en movimiento y cambio, desde un mundo siempre en formación?".

235. Ibid., p. 211, tradução nossa.

236. No original: “Todo el proceso es político porque cualquier construcción implica decisiones que afectan a las personas y los entornos en formas particulares".

237. Ibid., p. 131, tradução nossa. 
e contextualizadas - quer dizer, uma perspectiva que destaca nossa participação ativa em áreas de interesse comum -. ${ }^{238}$

Outro aspecto relevante foi com relação à representação do design no processo colaborativo. Quando optamos por dar início à oficina com as pessoas que já estavam no CAM, parti das minhas impressões e percepções levantadas na fase de imersão, que me indicavam como elas encaravam a prática do design. Para que discutir design, quando o foco do encontro era o próprio CAM e as suas demandas? Abrir mão da necessidade de impor múltiplas definições da palavra e seguir com a proposta elaborada com Mesquita, na qual tocaríamos em várias etapas do processo de design, foi uma tomada de decisão responsiva que além de não colocar em nós a responsabilidade completa, vestindo a postura de especialista, também evitava que ocorressem estranhamentos e afastamentos durante o processo, fato certificado com a participação de quase todos os participantes no último dia.

Assim como Lino evidenciou que muitos moradores da Maré não iam para o espaço do CAM por associarem a arte a um nicho do qual não faziam parte, compreendi que isso também ocorria com as ideias preconcebidas de design. O termo importado por si só já promovia um distanciamento, incluindo a associação ao caráter estetizante e elitista, por se tratar de um espaço que prioriza a cultura popular e a memória. Saber manejar as nossas e as suas expectativas em relação a isso foi um passo importante na pesquisa.

Somado a estas reflexões, ocorreram também dificuldades em utilizar as abordagens selecionadas na prática, visto que no momento da execução, enquanto adversidades ocorrem, as práticas ficam turvas e o que permanece efetivamente é a intuição no momento. Um exemplo foi quando um dos participantes, no primeiro dia de atividades durante a primeira etapa de conversas, questionou: "por que não vamos olhar o CAM juntos em vez de ficarmos discutindo sobre ele aqui sentados?" Intuitivamente, compreendi que o engajamento ocorria e era uma oportunidade para avançarmos

238 No original: "tanto la actividad reveladora como el hacer frente a las rupturas implican ir más allá de la idea comúnmente aceptada de que el mundo funciona en términos de representaciones mentales individuales de un 'problema'; en cambio, avanzan hacia una perspectiva de interacciones sociales modeladas y contextualizadas - es decir, una perspectiva que destaca nuestra participación activa en âmbitos de interés común -". 
juntos no processo colaborativo e, desta forma, todos levantamos e fomos olhar os espaços no interior do Centro de Artes.

A intuição pode ser compreendida, portanto, como a atenção. Assim como músicos e artistas observam a ação uns dos outros, percebendo o momento certo para atuarem intuitivamente, este processo seguiu um caminho similar, no qual a intuição orientava as fases do processo, ainda que apoiadas em um guia - tal como uma partitura ou um roteiro -, que avançava de acordo com as respostas recebidas, de modo que a colaboração emergia no diálogo e no fazer.

Bem como a intuição, a articulação também se mostrou presente como meio para colaboração, fosse nas sugestões dos participantes no segundo dia sobre locais para comprar materiais ou na formação de uma rede que permitiu que uma das participantes chegasse até a oficina por meio de uma rádio comunitária. Ainda que a responsabilidade de realização da oficina não tenha sido compartilhada em sua forma mais equilibrada, a articulação de Lino, Lopes e dos outros participantes permitiu que o evento ocorresse dentro de suas limitações. Para Bruno Latour (2011, p. 797) "a noção de rede é útil sempre que a ação deve ser redistribuída" e "o que era invisível torna-se visível, o que pareceu isolado agora é amplamente redistribuído".

Paralelamente, as redes permitem que haja informalidade nas ações, desprovendo-as de amarras, deixando-as livres e improvisadas, expandindo-as sem quaisquer cus$\operatorname{tos}^{239}$. Esta informalidade pode ser revisitada em nossa busca por materiais em locais inesperados ou em nossa capacidade de estabelecer uma parceria com uma editora para que ela doasse pallets de madeira para as atividades da organização, promovendo novas formas de colaboração. Podemos compreender, portanto, que os artefatos, espaços, localizações e a tecnologia são na realidade relações sociais (Latour, 2001, p. 226) em ação promovendo uma rede de atores humanos e não-humanos que propiciou eventos, como a oficina no contexto imbricado da Maré.

Por outro lado, a articulação envolve também forças de poder determinadas a partir de estruturas hierárquicas. Uma vez que assumi a postura de auto convite junto a parceiros que eu já possuía vínculos, o alcance do meu trabalho como designer ativista 
dependeu das redes e conexões que consegui tocar até aquele momento. Esta percepção me auxiliou compreender duas implicações necessárias para que o processo colaborativo fosse melhor compartilhado e legitimado entre atores da organização. A primeira é por meio do estabelecimento de outros vínculos dentro da Redes da Maré, evidenciando um lugar de ação do designer como ator interno, em que a autoria do processo é melhor distribuída. A segunda é através de uma melhor adaptabilidade do designer de acordo com as atividades que já ocorrem, por exemplo, a oficina ocorrer dentro do âmbito de uma rodada de cicloativismo ou realizada para a Marcha Contra Violência, que são prioridades no cronograma da organização.

Para tanto, a prática de diálogo é essencial, de forma que coloca o processo colaborativo em uma mesma linguagem e um mesmo idioma, fato ainda a ser superado ao longo do tempo, perdurando o vínculo nas trocas com a organização e inviabilizando términos ou fechamentos. A noção de diálogo postulada por Paulo Freire (1996) ainda precisaria ser melhor trabalhada neste contexto, de forma que as trocas entre designers e parceiros fossem mais horizontais. Freire ${ }^{240}$, ao debruçar-se sobre a relação educador e educando com o intuito de promover autonomia, sugere que os sujeitos dialógicos devem aprender e crescer na diferença, e que

é no respeito às diferenças entre mim e eles ou elas, na coerência entre o que eu faço e o que digo, que me encontro com eles ou com elas. É na minha disponibilidade à realidade que construo a minha segurança, indispensável à própria disponibilidade a realidade sem segurança (...).

Estas reflexões elucidam que o aprendizado acerca de práticas de colaboração no design ainda precisam ser ampliados e constantemente praticados com atenção e cuidado. Para Sennett (2013b, p. 93), a cooperação pode ser equilibrada em comunidades de mesmas ou diferentes espécies e encontrar limites e fronteiras é uma forma de promover esse equilíbrio. "O equilíbrio depende da troca"241 e para isso, ela deve ser constante e transformadora.

\subsubsection{A colaboração por meio da performatividade}

240. Ibid., p. 85.

241. No original: "Balance depends on exchange". 
Após a intuição e a articulação, chegamos à última camada de reflexões sobre a colaboração em processos de design: a performatividade. Oriunda de estudos do filósofo britânico John L. Austin, a performatividade é aqui compreendida a partir de sua leitura na arquitetura e no urbanismo por meio dos pesquisadores Sophie Wolfrum e Nikolai Brandis (2015). Para os autores ${ }^{242}$, a "performatividade refere-se ao poder transformador de um ato" e pode ser interpretada no modo como o espaço é moldado pelas interações entre pessoas e no uso dos objetos na vida cotidiana.

No caso da oficina realizada, o processo que partia da identificação de demandas do espaço do CAM até a efetiva construção de coisas que respondessem a essas necessidades propiciou um novo olhar aos participantes sobre o espaço acerca de como ele pode ser usado, levando em consideração a sua imprevisibilidade. Nos termos de Wolfrum e Brandis ${ }^{243}$, pensar a performatividade do espaço implica em reconhecer sua indeterminação como um princípio projetual, de modo que são seus usos que indicam sua performance e seus significados. Um exemplo disso aparece quando os autores citam que "uma praça dificilmente tem qualquer relevância urbana na medida em que é apenas pedras, árvores, estilo e cor. Somente quando é usada, torna-se um palco para a vida urbana, traz atores e espectadores juntos em um evento, sua arquitetura envolve significado urbano"244.

O aspecto da performatividade foi também trabalhado pela pesquisadora Kristina Niedderer (2007) quando desenvolveu um objeto que obrigava seu usuário exercitar a reflexão para poder usá-lo. Na ocasião, Niedderer desenvolveu um copo que não ficava em pé sozinho e possuía furos em sua base, de maneira que o usuário precisasse ficar atento durante o uso evitando que o copo vazasse ou caísse. Embora a reflexão neste caso tenha sido no uso de um objeto específico, podemos transferir esta perspectiva da ação de uso para a ação de construção coletiva, visto que ao produzir objetos, testá-los, levá-los de dentro para fora e o inverso, a reflexão era promovida nos participantes por meio do teste e do fazer.

242. Ibid., p. 27.

243. Ibid., p. 14.

244 No original: "A square is hardly of any urban relevance insofar as it is just stones, trees, style, and color. Only when it is used, becomes a stage for urban life, brings actors and spectators together in an event, does its architecture enfold urban significance" (Wolfrum; Brandis, 2015, p. 14). 
A mesma ideia foi também elaborada por Gunn e Donovan (2012) ao realocar os protótipos de design, tradicionalmente entendidos como soluções de design, para artefatos que façam a relação entre as práticas do passado e do presente, provocando reflexões em questões latentes ou gerando novas alternativas. Neste sentido, como ressaltam Anastassakis e Szaniecki (in Smith et al., 2016, p. 125-126), essa modificação transforma os protótipos em artefatos provocadores que propiciam conversas baseadas na produção de significados coletivos e conhecimento, criando "a possibilidade de aproximar o domínio do usuário ao processo de design, investindo nela todas as controvérsias, desafios e implicações que ocorrem quando artefatos são envolvidos por pessoas em situações reais. Menos prescritivo, o design torna-se uma atividade crítica".

A capacidade de reflexão a partir da construção dos artefatos que provocam conversas e diferentes percepções sobre diferentes usos no espaço possibilita que designers e não designers pensem juntos sobre o lugar e suas experiências, forjando assim outra leitura sobre a colaboração. Assim, o processo performativo pôde propiciar uma colaboração engajada que as pessoas aprendiam juntas enquanto discutiam sobre o espaço, especulando sobre seus usos futuros.

Este aspecto foi também reconhecido no trabalho do coletivo britânico Assemble, que compartilha seu ateliê de trabalho com profissionais como serralheiros, ceramistas e marceneiros, possibilitando que a colaboração entre arquitetos e mestres de oficina ocorra no fazer coletivo. Além disso, o coletivo é amplamente conhecido por adotar em sua abordagem principal de atuação a construção coletiva de espaços e objetos a partir da necessidade de grupos que trabalham junto. Segundo Jane Hall245, membro do coletivo há oito anos, esta forma de atuar permite que o engajamento ocorra por meio do fazer, da experimentação, do teste e da reflexão, sem preocupações com autoria ou escala, "fazendo o melhor da habilidade que as pessoas já têm e fazendo do uso um meio para compreender a prática" ${ }^{246}$ (comunicação oral).

245. Tive a oportunidade de conversar com Jane Hall durante a sua vinda para uma palestra da 11 Bienal de Arquitetura, na qual apresentou alguns projetos do coletivo Assemble e forneceu uma entrevista para a página Archdaily Brasil. A entrevista está disponível em: < https://www.archdaily. com.br/br/884805/11a-bienal-de-arquitetura-de-sao-paulo-e-british-council-promovem-palestra-com-jane-hall-do-assemble>. Acesso em 7 Dez. 2017. 
Cada uma dessas camadas de colaboração apresentadas entre os tópicos 4.1.1 à 4.1.6 indica que é possível compreender que há muitas nuances no que se refere a projetar junto, revelando outras formas de fazer a partir da identidade local, seus hábitos e vivências. Embora o processo não tenha sido continuamente fluido, ele certamente foi rico em aprendizados tanto no fazer com os outros, quanto no reconhecimento do espaço e suas potencialidades, evidenciando consequentemente novas oportunidades para o seu cotidiano.

\subsection{Desdobramentos após o término do processo narrado}

Terminada a oficina, retornei a Maré apenas em setembro de 2017 a fim de participar de uma reunião no local e promover outra atividade externa à pesquisa de mestrado, agora com a colaboração de pesquisadoras do LaDA/ESDI/UERJ. Nesta ocasião, pude conversar com Lino e Lopes sobre os artefatos que havíamos construído e escutar a sua opinião sobre os desdobramentos do processo e os usos engendrados.

Alguns pontos nesta conversa foram relevantes para o resultado desta pesquisa:

- o sofá itinerante foi tão utilizado que um deles teve uma parte quebrada, a qual realizamos a sua manutenção, comprovando a necessidade de uso e convivência no espaço;

- diversas pessoas retornaram ao CAM perguntando sobre outras oficinas de marcenaria, interessadas na possibilidade de aprender processos construtivos enquanto faziam um artefato que seria utilizado posteriormente;

- Lino e Lopes perceberam nos sofás a oportunidade de criar espaços de convivência para receber convidados especiais (figura 61) e também ampliaram a sua reflexão espacial a partir dos objetos em uso, pensando em outras ideias similares que poderiam ser apropriadas como áreas de estudo e leitura;

- a equipe do CAM que participou do processo passou a utilizar materiais da própria Maré para fazer seus mobiliários, fato comentado por Yuri Lobo nesta visita em outubro; 
Uma vez que o design colaborativo pode atravessar a linha tênue entre o fazer juntos e o altruísmo, dialogar sobre este aspecto foi essencial para compreender a postura ativista no trabalho. Não é porque me auto convidei para estas experiências que elas simbolizam atos de caridade, há na verdade uma real reciprocidade que é efetivada quando Lino e Lopes me permitem pesquisar sobre a Maré, enquanto compartilho com eles as minhas habilidades e conhecimentos para trabalharmos juntos as questões de interesse cotidianas.

Este aspecto foi revisitado por Sennett (2013b, p. 279) ao discorrer sobre a subversão da cooperação em forma solidariedade no século XX, na qual muitos regimes autoritários se apropriavam do ato de cooperar como meio para manipulação social. Outro ponto citado está na propagação do individualismo nas sociedades impactadas por sistemas neoliberais massificantes que evitam que as sociedades pensem no bem comum para focar no indivíduo como prioridade. Para o autor ${ }^{248}$ "o poder perverso da solidariedade, em sua forma de nós contra eles, permanece vivo nas sociedades civis das democracias liberais, assim como nas atitudes européias em relação aos imigrantes étnicos que parecem ameaçar a solidariedade social ou nas demandas americanas para o retorno aos 'valores familiares"' ${ }^{\prime 2}$.

É interessante notar como esta atitude vai em direção oposta à percebida por Lino e à minha postura como ativista no design neste processo. Certamente, ainda há um grande distanciamento entre as práticas de design em relação às questões sociais e uma falta de consciência crítica sobre o impacto de ações colaborativas em espaços urbanos, especialmente como os da Maré. Por isso, compreende-se que manter uma postura de autocrítica, de atenção e de cuidado é um aprendizado relevante e necessário a se carregar em processos colaborativos em design. Com base nas reflexões apresentadas, introduzo o último tópico deste capítulo, no qual compilei observações sobre a colaboração em design a partir de duas entrevistas realizadas ao final da pesquisa com a Dra. Chiara Del Gaudio.

248. Ibid., p. 279.

249.No original: "The perverse power of solidarity, in its us-against-them form, remains alive in the civil societies of liberal democracies, as in European attitudes toward ethnic immigrants who seem to threaten social solidarity, or in American demands for a return to 'family values'". 


\subsection{Observações sobre a colaboração em diálogos externos}

Nos últimos meses de pesquisa foi possível realizar duas entrevistas semi-estruturadas com a Dra. Chiara Del Gaudio. Pesquisadora italiana residente no Brasil, concluiu a sua pesquisa de doutorado em design na PUC-Rio em 2014 junto a uma organização do Complexo da Maré e atualmente leciona na Unisinos ${ }^{250}$, na cidade de Porto Alegre, Rio Grande do Sul. Diversas observações relevantes para este trabalho foram levantadas durante estas entrevistas, as quais serão apresentadas a seguir.

Ao conversar com Del Gaudio ${ }^{251}$ foi possível levantar reflexões para práticas de colaboração em design que evitam concepções fantasiosas ou irreais no que se refere a atuar com outras pessoas. Ao perguntar sobre o seu entendimento acerca do design colaborativo, Del Gaudio é cuidadosa e nos relembra que devemos sempre considerar que a colaboração não é um assunto recente no campo, mas um tópico que vem sendo discutido e trabalhado desde os anos 1970, migrando do termo 'participativo' para 'colaborativo' nos anos 2000. Em sua perspectiva, a colaboração pode incluir diversos tipos de dinâmicas humanas, incluindo a competição e o conflito, de forma que não há um caminho único em que todas as partes envolvidas naveguem para uma mesma direção, já que interesses podem ser destoantes em um mesmo grupo de atores.

Neste sentido, para a pesquisadora é este o ponto que diferencia a colaboração da cooperação, visto que "o que é decidido pela maioria, um gerenciamento de discursos, pode criar ou impor um consenso dependendo do contexto" que se trabalha. Por conta disso, a pesquisadora observa que estruturas de poder ou âmbitos institucionalizados em que ocorrem processos de colaboração podem afetar diretamente a criatividade dos participantes.

Ao dialogarmos sobre a postura do pesquisador ou profissional em campo com as pessoas, Del Gaudio afirma que não há uma performance a ser tomada, mas que é necessário tornar-se parte do contexto e ser um ator como os outros participantes. Em suas palavras, ressalta que "a gente se coloca como parte do contexto, a gente tem voz

250. Unisinos é sigla para Universidade do Vale do Rio dos Sinos. Mais informações na página oficial da universidade. Disponível em: <http://www.unisinos.br/>. Acesso em: 5 de Fev. 2018.

251. As observações apresentadas a seguir foram levantadas por Chiara Del Gaudio durante entrevista no dia 22 de setembro de 2017, virtualmente (Skype), com uma hora e meia de duração. 
como os outros e eu não acho que o designer é neutro e não possui lugar de fala, ele tem voz, ele é um ator como os outros". Esta observação foi extremamente relevante para revisar a minha postura em campo, especialmente durante a terceira fase na oficina no CAM. Ao revisitar esta etapa, foi possível compreender que é efetivamente impossível mediar um processo sem colocar-se como um ator inserido e participante daquele contexto.

Por este caminho, Del Gaudio suscita a importância de ir ao lugar e entender se as pessoas querem de fato fazer ou não algo, já que ativar o processo colaborativo compreende também tentar entender o conhecimento do outro. Para tanto, a pesquisadora sugere a perspectiva dos autores Sanders e Stappers (2008), que apresentam níveis de criatividade em que devemos reconhecer a capacidade criativa e as formas de expressão de todos os atores envolvidos.

Entretanto, Del Gaudio pontua que permitir que o outro tenha uma real expressão é ainda um desafio, especialmente porque o contexto influencia diretamente nas formas de atuação dos atores que seguem as regras do lugar em que estão inseridos, usualmente determinadas por ordens hierárquicas e mecanismos existentes. Embora acredite que quebrar as formas de pensamento existentes integralmente seja uma utopia, buscar o lugar em que o outro está e trabalhar com ele a fim de propiciar formas de expressão é uma via necessária para trabalhos com intuito propositivo e de colaboração. Uma de suas observações acerca do papel do profissional ou pesquisador reafirma esta percepção: "a gente tem sim esse papel no dia-a-dia, a nossa contribuição, o que podemos hoje chamar de design, é entender como todos podem contribuir criativamente, e conseguir entender como o outro expressa a sua opinião", já que o fato de uma prática de design ser colaborativa "não necessariamente dá voz aos participantes".

Outro aspecto relevante mencionado foi com relação ao estabelecimento de termos entre as partes envolvidas de modo que seja possível promover uma relação de confiança na troca entre designer e participante. Durante esta pesquisa, esta observação sobressaiu em alguns momentos, visto que como mantive o processo aberto desde o início e com poucos termos acordados, lidei com sentimentos de insegurança e dúvida com relação as trocas participativas, ainda que a minha relação com os parceiros fosse muito aberta e disponível. 
Consonante a estas reflexões, indaguei a pesquisadora sobre o sentimento de solidão que emerge em pesquisas de campo, nas quais o designer pesquisador é o principal ator interessado em propor um processo de colaboração. Para Del Gaudio estar sozinho pode representar o distanciamento com o grupo que se trabalha, visto que os atores do contexto já possuem a sua própria rotina e os seus objetivos são diferentes daqueles do pesquisador, tal como peças de quebra-cabeça de formatos diferentes e não encaixáveis.

Em sua perspectiva, esta sensação é completamente diferente de quando você já é parte do grupo desde o início ou quando você se torna parte do lugar, situações opostas a casos quando um "elemento externo quer entrar e cutucar o sistema para que ele de uma resposta". Todavia, Del Gaudio é assertiva ao colocar que quando se está sozinho, o processo de inserção é mais fácil do que entrar inicialmente com um grupo de pesquisadores ou profissionais, já que a ambientação individual acaba por obrigar o pesquisador a se infiltrar no contexto e interagir com as pessoas do cotidiano.

Com relação a fases anteriores as de co-criação, a pesquisadora sugere que os momentos informais são chave, ou seja, "o dia-a-dia, participar genuinamente, isso é o mais verdadeiro, abre para outras possibilidades, outra dimensão de entendimento entre as pessoas e abre um canal de comunicação nas relações pessoais", fato que "não acontece no workshop, somente no dia-a-dia ao viver a vida deles". Deste modo, em seu ponto de vista, "ser designer é ser interessado pelas pessoas e se interessar pelo que elas se interessam".

Esta observação foi também observada nesta pesquisa, especialmente na transição entre a fase de imersão em campo e a fase de proposição, já que na imersão a participação ocorreu de forma mais fluida e inserida na rotina da organização, enquanto na proposição alguns ruídos de comunicação foram percebidos, como o desencontro entre as prioridades dos parceiros ou a dificuldade de compartilhamento das responsabilidades durante a atividade no CAM. Somado a isso, a questão do tempo, já mencionada anteriormente na dissertação, é um aspecto chave para Del Gaudio: "em três meses de pesquisa de doutorado eu tinha um olhar sobre o lugar, depois de oito meses eu tinha outro, aos poucos você vai entendendo o contexto e isso demanda tempo, uma evolução própria no contexto". 
O tempo é efetivamente um fator que deve ser levado em consideração, uma vez que designers acabam preocupando-se muito mais com o resultado do que com o processo de participação em si. Entretanto, foi possível notar durante a pesquisa de mestrado que o foco no resultado concreto é algo transmitido no ensino em design durante toda a formação dos alunos e visualizado, especialmente, na busca incessante por solucionar problemas.

Além disso, uma vez que a improvisação foi um tópico recorrente neste trabalho, indaguei a pesquisadora sobre a sua percepção acerca da improvisação em atividades participativas que esteve envolvida e se esse é um tópico observado em seus processos colaborativos. Para Del Gaudio252, a "improvisação está na base de todos os processos de inovação. (...) No dia-a-dia a gente improvisa o tempo todo", entretanto é preciso reconhecer o quanto as pessoas se libertam no processo de design, já que "quando não tem essas barreiras elas conseguem improvisar". A pesquisadora acrescenta que há "também a dificuldade das pessoas improvisarem e a sociedade dizer como devemos fazer as coisas e a melhor forma, a forma mais eficiente de fazer", o que acaba por limitar esta prática.

Sobre improvisação, adicionou "sempre faço uma ligação com uma dança que chama contact improvisation, você improvisa os passos o tempo todo, não tem regra nenhuma, e essa é a parte mais difícil para mim, porque aprendi a fazer coisas para gerar um resultado". É interessante notar a associação da pesquisadora com a dança, relevante inclusive na ponte com os rituais de músicos e artistas situada por Sennett (2013b) e apresentada no tópico anterior. Pensar a improvisação como um meio para colaboração foi um desdobramento curioso no trabalho, evidenciado durante a troca com participantes no contexto da Maré, sem dúvida, um fator que facilitou o processo para que encontrássemos caminhos possíveis dentro da limitação de tempo e recursos.

Por fim, dialogamos sobre a ação de designers para promover a autonomia em organizações sociais. Para a pesquisadora, designers podem contribuir para isso, porém sem necessariamente focar em encontrar soluções. Em sua visão, a possibilidade em unir tradições locais junto a inovação, tópico abordado também por Arturo Escobar (2016), 
é um caminho viável se ocorrer na forma e perspectiva do contexto que se trabalha. Este aspecto foi revelado constantemente na pesquisa, visto que os fatores contextuais complexos impedem que a autonomia ocorra de uma forma geral na vida dos moradores da Maré e no âmbito da Redes da Maré, enquanto a participação do design neste aspecto poderia ocorrer apenas para contribuir como mais um agente nesta busca, ou como sugere Ingold (2012), como um nó de fios em uma malha de emaranhados.

Embora o tempo de pesquisa tenha permitido apenas o diálogo com uma única pesquisadora, conversar com Del Gaudio foi uma oportunidade relevante para o trabalho, trazendo percepções complementares de uma pessoa que efetivamente trabalhou com o mesmo contexto desta dissertação. É evidente que ainda há muitas questões e desafios para pesquisadores e designers que intencionam atuar com pessoas em diferentes contextos e condições, no entanto, concluo este capítulo com a perspectiva de que a colaboração em design está apenas se iniciando, principalmente em um país tão plural e rico quanto o Brasil. 


\section{Considerações finais}

Embora a pesquisa tenha chegado ao fim, o processo de trabalho e troca com os parceiros na Maré continua vivo e latente. Muitos aprendizados evidenciam a urgência que os campos projetuais têm de se aproximar e envolver pessoas que já constróem a cidade como uma condição cotidiana. Reconhecer que o fazer projetual não é restrito ao profissional ou pesquisador é sem dúvida um caminho necessário para que outros processos de colaboração existam.

A partir deste longo trabalho compreendi que a colaboração possui muitas nuances e a aplicação de abordagens sem atenção as particularidades do contexto impede que trocas participativas sejam mais engajadas e condizentes com a vida das pessoas envolvidas. Ao mesmo tempo, reconhecer as práticas locais, os modos de fazer e usar são imprescindíveis para que processos colaborativos em design não fiquem fadados a trocas superficiais ou deixem de incorporar a capacidade de continuação do processo por parte dos atores ou parceiros locais.

Somado a isso, adotar um viés relacional no design, tal como abordado no primeiro capítulo da dissertação, exige que as práticas participativas sejam constantemente revisitadas criticamente e que a busca por um design nosso, baseado em nossos aspectos culturais brasileiros, cariocas e mareenses, não seja cessada. Ainda que Magalhães e Bo Bardi tenham atuado por meio de outras perspectivas políticas e econômicas, reconhecer as formas vernaculares de ação é um traço indispensável para que o design ganhe outras dimensões sociais, políticas, culturais e econômicas. Já não mais vivemos em uma época aficionada pelos vislumbres da industrialização, nem sequer em uma época que só fazer coisas para usuários irá solucionar todos os nossos proble- 
mas. Vivemos em um momento de urgência, em que a atenção, o cuidado e a capacidade de ouvir o outro são atitudes raras em todos os âmbitos sociais e representam um gesto político na atitude profissional.

Como visto no capítulo dois sobre a Maré, a luta e a resistência diárias ainda irão perdurar pelo tempo e tomar como aprendizado a história, memória e identidade que os residentes daquele território possuem foi, sem dúvidas, o maior enriquecimento de toda a trajetória de pesquisa. Ainda que a minha participação no âmbito da Redes da Maré ainda esteja apenas começando, posso afirmar com toda a certeza que conhecer e compreender este espaço tão resiliente na cidade do Rio de Janeiro, local em que cresci e vivi praticamente a minha vida toda, me trouxe aprendizados únicos que os âmbitos acadêmico ou corporativo jamais me providenciariam. Reconhecer a Maré representa, na verdade, olhar para o futuro da cidade com perspectivas menos alienadas e mais conscientes das mudanças impostas à cidade, como a ação de grandes eventos vorazes que apagaram a luta e a identidade histórica de muitas famílias. Em razão disso, enfatizo que o design e a arquitetura precisam despertar para o que efetivamente ocorre a fim de deixarem seu posto de ferramenta padronizada e adotarem uma postura política de resistência com quem já produz a cidade real.

As vivências relatadas no capítulo três evidenciam que o design ainda é associado a uma prática elitizada e segregadora, entretanto, mostram que há espaço para que participe da vida das pessoas, contanto que não imponha ou ultrapasse questões de interesse locais. Do contrário, a prática se perde e remanesce vazia e superficial. Além disso, foi possível compreender que correspondência é na verdade negociação, encontro do meio com o intervalo, atenção e hábito. Deixar-se levar no cotidiano de Geisa Lino e Douglas Lopes me permitiu observar e alcançar patamares na pesquisa que jamais teriam ocorrido se tivéssemos estabelecido uma troca de ação propositiva desde o início, o que indica que ainda podemos aprender muito com práticas como a observação participante e com a antropologia como um todo. Tim Ingold estava certo ao dizer que a transformação vem do entrelaçamento entre as experiências e os intervalos de tempo, mas para isso devemos nos entregar aos emaranhados da vida cotidiana, ainda que haja insegurança, medo ou incerteza. 
Alcançar uma prática propositiva foi um privilégio neste trabalho, apesar dos obstáculos e desafios. Graças a esta oportunidade, pude perceber que designers e pesquisadores ainda não estão preparados para atuar fora da sua própria zona de conforto, isto é, realizar a proposição sem a observação, a reflexão e a crítica projetual. Na minha perspectiva como pesquisadora do design, isso orienta que já conquistamos outras formas de fazer design, no entanto temos muito trabalho pela frente para que a colaboração seja mais flexível e intuitiva.

Em paralelo, a oportunidade me elucidou que ainda precisamos experimentar e testar caminhos com as pessoas, do contrário, ficamos travados em uma advocacia paralisante, sem experiências para dialogar, aprender e enriquecer as formas de fazer que já possuímos, ainda que posteriormente elas precisem ser modificadas ou repensadas. Colocar as abordagens teóricas em prática não é tão prático e intuitivo como quando vemos em estudos de caso e seus resultados, pois cada situação possui as suas próprias particularidades que impedem que os acontecimentos sigam exatamente um programa ou cronograma estipulado. O processo é sem dúvida o melhor meio para compreender os desafios e obstáculos e compreender outros caminhos que podem ser adotados, tal como observei que talvez devesse atuar em atividades já recorrentes ou me inserir mais a fundo na iniciativa. Por isso, trata-se de migrar de uma prática de design padronizada e rigorosa para uma colaboração flexível e intuitiva na qual nos deixamos aprender com o contexto e as pessoas de acordo com o interesse coletivo e a capacidade de engajamento social, ainda que esta seja uma tarefa difícil e nem sempre óbvia.

Como discutido no capítulo quatro, a colaboração pode ser interpretada em diversos modos, o que nos permite abrir mão da ideia pré-concebida de que realizá-la em processos de design é apenas trabalhar com o outro. Colaborar no design é cooperar, aprender, improvisar, corresponder, intuir, articular e refletir sobre os usos e as formas de fazer, incluindo abrir mão de abordagens e suas etapas a fim de preservar e cultivar vínculos e parcerias. Vimos também que colaborar não é um ato de caridade, mas sim de reciprocidade, que por meio do diálogo contínuo e o encontro de uma mesma linguagem entre as partes é possível encontrar termos comuns para trocas mais relacionais. Finalmente, a partir do diálogo com Chiara Del Gaudio, conseguimos ver como a voz e a expressão são imprescindíveis e que o colaborar por si só não habilita esta 
capacidade que, muitas vezes, está associada ao lugar, a cultura local e as estruturas hierárquicas estabelecidas.

Chegamos ao término de um começo, um processo construído a muitas mãos que possibilitou que este trabalho se concretizasse e criasse suas primeiras raízes. As trocas com os parceiros da pesquisa continuarão e novos aprendizados e as experiências vão trazer outras indagações possibilidades. Considerando os próximos passos deste processo, algumas questões já se apresentam: como a cultura e o comportamento influenciam em nossas práticas como designers? Se designers compreenderem melhor o contexto que estão trabalhando, suas formas de fazer, usar e improvisar, serão capazes de promover práticas colaborativas mais compartilhadas e engajadas? Qual o lugar de fala de profissionais e pesquisadores em práticas colaborativas ativistas? Como podemos nos entregar aos tempos de turbulência e caos (Haraway, 2016) sem perdermos a nossa resistência e generosidade? Carrego comigo estas indagações e assim concluo esta dissertação de mestrado. 


\section{Referências bibliográficas}

ABRAHÃO, S. L. Espaço público: do urbano ao político. São Paulo: Annablume, 2008.

ACOSTA, A. O Bem Viver: uma oportunidade para imaginar outros mundos. São Paulo: Autonomia Literária, Elefante, 2016.

AGIER, M. Antropologia da cidade: lugares, situações, movimentos. São Paulo: Terceiro Nome, 2011.

ANASTASSAKIS, Z. Triunfos e impasses: Lina Bo Bardi, Aloisio Magalhães e a institucionalização do design no Brasil. Tese de Doutorado. Programa de Pós-Graduação em Antropologia Social/Museu Nacional, Universidade Federal do Rio de Janeiro. Rio de Janeiro, 2011.

. Vinculações entre Design e Cultura no Brasil: a Outra Vertente de Lina Bo Bardi e Aloisio Magalhães. In: Design e/é patrimônio. Rio de Janeiro: CCD, 2012. Editorial. .;SZANIECKI, B. Conversation Dispositifs: Towards a Transdisciplinary Design Anthropological Approach. In SMITH, R. C.; VANGIKILDE, K. T.; KJAERSGAARD; OTTO, T.; HALSE, J.; BINDER, T. Design Anthropological Futures. London; New York: Bloomsbury, 2016, p. 121-138.

; Refazendo tudo: a peleja entre Pezão, os cupins e outras estranhas emanações miasmáticas em uma velha escola de desenho industrial na Lagoa do Boqueirão da Ajuda. Artigo no Prelo, 2018.

ARAUJO, R. M. E. de. Um olhar sobre o design social e a prática do design em parceria. In OLIVEIRA, A. J. de; FRANZATO, C.; DEL GAUDIO, C. (Orgs.) Ecovisões Projetuais: pesquisas em design e sustentabilidade no Brasil. São Paulo: Blucher, 2017, p. 19-28.

HARPER, P. Walter's Way. The Anarchist Housing Estate. Architectural Foundation, 11 Ago. 2015. Disponível em: <http://www.architecturefoundation.org.ulk/programme/2015/ walter\%E2\%80\%99s-way-the-anarchist-housing-estate>. Acesso em: 10 Jan. 2018. 
ARENDT, H. A condição humana. Rio de Janeiro: Forense Universitária, 2007

ASSEMBLE STUDIO. 2018. Assemble. Disponível em: < http://assemblestudio. co.uk/?page_id=827>. Acessado em 10 de Jan. 2018.

SAKURAI, T.; SANTOS, M. C. L. 2017. AUP0479 - Design para Sustentabilidade.

Página oficial da disciplina AUP0479 - Design para Sustentabilidade oferecida pelo Departamento de Projeto da FAU-USP. Disponível em: <http://www.usp.br/residuos/ aupo479/>. Acesso em 19 Nov. 2017.

BARBER, D. Militant architecture: Destabilizing architecture's disciplinarity. In: The Journal of Architecture, Vol. 10, N. 3, 2005, p. 245-253.

BARBOSA, J. L.; DIAS, C. G. (orgs). Solos Culturais. Rio de Janeiro: Observatório de Favelas, 2013.

BARDI, L. B. L’impasse del design. L'esperienza nel Nordest del Brasile. São Paulo: Charta, Milano, 1995.

BINDER, T.; BRANDT, E.; EHN, P.; HALSE, J. Democratic design experiments: between parliament and laboratory. In: CoDesign International Journal of CoCreation in Design and the Arts, v.11, no 3-4, London: Taylor \& Francis, 2015, p. 152-165.

BELL, B.; WAKEFORD, K. (Eds). Expanding Architecture: Design as Activism. New York: Metropolis Books, 2008.

BONSIEPE, G. Design, cultura e sociedade. São Paulo: Blucher, 2011.

BOUFLEUR, R. N. Fundamentos da Gambiarra: A improvisação Utilitária

Contemporânea e seu Contexto Socioeconômico. 2013, 252 f. Tese (Doutorado - Área de Concentração: História e Fundamentos da Arquitetura e do Urbanismo) - FAUUSP, Universidade de São Paulo, 2013.

BRAGA, M. da C. ABDI e APDINS-RJ. São Paulo: Editora Blucher, 2011.

BUCHANAN, R. Wicked Problems in Design Thinking. In Design Issues, v. 8, no․ 2, 1992, p. 5-21.

CANCLINI, N. G. Las cultura populares en el capitalismo. Mexico, DF: Nueva Imagen, 1989.

CARDOSO, F. de A. O Universo simbólico do design gráfico vernacular. 2010, $193 \mathrm{f}$.

Tese (Doutorado em Design) - Pontifícia Universidade Católica do Rio de Janeiro, Rio de Janeiro, 2010.

CASTRO, C. Textos básicos de antropologia: cem anos de tradição: Boas, Malinowski, Lévi-Strauss e outros. Rio de Janeiro: Zahar, 2016.

CHAUÍ, M. de S. Escritos sobre a universidade. São Paulo: Unesp, 2001. 
COUTO, R. M. de S.; NEVES, M. A. C. M. O ensino da disciplina de projeto básico sob o enfoque do design social. 1991, 74 f. Dissertação (Mestrado) - Pontificia Universidade Católica do Rio de Janeiro, Departamento de Educação, Rio de Janeiro, 1991.

O Design Social na PUC-Rio. In OLIVEIRA, A. J. de; FRANZATO, C.; DEL GAUDIO, C. (Orgs.) Ecovisões Projetuais: pesquisas em design e sustentabilidade no Brasil. São Paulo: Blucher, 2017, p. 29-36.

CODE. 2018. Página oficial do Center for Codesign Research. Disponível em: <https:// codesignresearch.com>. Acesso em: 2 Jan. 2018.

CROSS, N. Design Participation. New Jersey: Academy Editions Ltd, 1972.

DATA LABE. Página oficial da organização. Disponível em: <http://datalabe.org/>. Acesso em 16 Jan. 2018.

DE CERTAU, M. A Invenção do Cotidiano: artes de fazer. São Paulo: Vozes, 2014. DEL GAUDIO, C. Design Participativo e Inovação Social: a influência dos fatores contextuais. 2014, 263f. Tese (Doutorado) - Pontifícia Universidade Católica do Rio de Janeiro, Departamento de Artes e Design, 2014.

.; OLIVEIRA, A. J. de; FRANZATO, C. The influence of local powers on

Participatory Design processes in marginalized conflict areas. In Proceedings of the 13th Participatory Design Conference: Research Papers, v. 1, 2014, p. 131-139.

DI SALVO, C. Design and the Construction of Publics. In: Design Issues, v.25, nํㅡ, Winter 2009, p. 48-63, Cambridge: MIT Press, 2009.

Adversarial design. Cambridge: MIT Press, 2012.

E-FLUX JOURNAL. Bienal de São Paulo. E-flux Journal, 23, Jan 2018. Disponível em: <http://www.e-flux.com/announcements/173353/11th-sa-o-paulo-architecturebiennial/>. Acesso em 28 de Nov. 2017.

ESCOBAR, A. Diseño para las transiciones. In Etnografias Contemporáneas, v.3, nํ4, 2017, p. 32-63.

Autonomía y Diseño. La realización de lo comunal. Cauca: Universidad del Cauca, 2016.

La invención del Tercer Mundo Construcción y deconstrucción del

desarrollo. Caracas: Fundación Editorial el perro y la rana, 2007.

FERRARA, L. D. Design em espaços. São Paulo: Rosari, 2002.

FEZER, J. Design for a post Neo-liberal City. E-flux Journal, 17, jun 2010. Disponível em: <http://www.e-flux.com/journal/design-for-a-post-neoliberal-city/>. Acesso em: 29 Jan. 2017. 
FREIRE, P. Pedagogia da Autonomia. Saberes Necessários à Prática Educativa. São Paulo: Paz e Terra, 1996.

FOOTE-WHYTE, W. Treinando a Observação Participante. Tradução de Claudia Menezes. In: Guimarães, A. Z. (Org.). Desvendando Máscaras Sociais. Rio de Janeiro: Francisco Alves Editora, 1975, p. 77-86.

FUAD-LUKE, A. Design Activism: beautiful strangeness for a sustainable world. London: Earthscan, 2009.

GADANHO, P. Uneven Growth: Tactical Urbanisms for Expanding Megacities. New York: The Museum of Modern Art, 2014. 176 p. Catalog.

Gamman, L.; Thorpe, A. Design with society: why socially responsive design is good enough. In CoDesign, v. 7, no 3-4, 2011, p. 152-165.

GROSSMAN, V. A arquitetura e o urbanismo revisitados pela internacional situacionista. São Paulo: Annablume, 2006.

GUATTARI, F. As Três Ecologias. Campinas, SP: Papirus, 2012.

GUNN, W., OTTO, T., SMITH, R. C. (Eds). Design Anthropology: Theory and Practice. London: Bloomsbury, 2013.

, DONOVAN, J. (Eds). Design and Anthropology. Farnham: Ashgate, 2012

GUSMÃO, G. Rua dos Inventos: Desenho Industrial e Responsabilidade Social. In Perspectivas do ensino de design na pós-graduação, São Paulo, 2001, p. 190.

HARAWAY, D. J. Staying with the Trouble: Making Kin in the Chthulucene. London: Duke University Press, 2016.

IBARRA, M. C. O design por não-designers (DND): as ruas de Belo Horizonte como inspiração para o design. 2014, 112f. Dissertação (Mestrado) - Universidade do Estado de Minas Gerais, Departamento de Design, 2014. ; ANASTASSAKIS, Z. O design e suas possíveis interações com práticas criativas desenvolvidas por não designers. In Anais do 1o Simpósio de Pós-graduação em design da ESDI, Rio de Janeiro, 2015.

IBGE - Instituto Brasileiro de Geografia e Estatística. Censo demográfico 2010: aglomerados subnormais : primeiros resultados. Disponível em: <http://biblioteca.ibge. gov.br/visualizacao/periodicos/92/cd_2010_aglomerados_subnormais.pdf> . Acesso em: 25 Mai. 2015.

IBGE - Instituto Brasileiro de Geografia e Estatística. Censo demográfico 2010: aglomerados subnormais : informações territoriais. Disponível em: <http://fw.atarde.uol. com.br/2013/11/1367185.pdf>. Acesso em: 25 Mai. 2015. 
IDEO. Página web da IDEO. Disponível em: https://www.ideo.com/. Acesso em: 20 Fev. 2017. INGOLD, T. On human correspondence. In Journal of the Royal Anthropological Institute, v. 23, no 1, 2016, p. 9-27. DOI: 10.1111/1467-9655.12541.

From the Transmission of Representations to the Education of Attention. In WHITEHOUSE, H. (ed.), The Debated Mind: Evolutionary Psychology Versus Ethnography, Oxford: Berg, 2001, 113-153.

Introduction: The Perception of the User-Producer. In: GUNN, W., DONOVAN, J. (Eds). Design and Anthropology. Farnham: Ashgate, 2012, p. 19-35.

.; HALLAM, E. Creativity and Cultural Improvisation: An Introduction. In Ingold, Tim; Hallam, Elizabeth (Eds). Creativity and Cultural Improvisation. Oxford: Berg, 2007, p. 1-24.

.; GATT, C. From description to correspondence: Anthropology in real time. In GUNN, W., OTTO, T., CHARLOTTE-SMITH, R. (Eds). Design Anthropology: Theory and Practice. London: Bloomsbury, 2013, p. 139-158.

Making: Anthropology, archaeology, art and architecture. London:

Routledge, 2013.

Trazendo as coisas de volta à vida: Emaranhados criativos num mundo de materiais. In Horizontes Antropológicos, Porto Alegre, ano 18, no 37, p. 25-44, jan./jun. 2012. JACQUES, P. B. Estética da Ginga: A arquitetura das favelas através da obra de Hélio Oiticica. Rio de Janeiro: Casa da Palavra, 2007.

. Cartografias da Maré. In VARELLA, D., BERTAZZO, I., JACQUES, P. B. Maré: vida na favela. Rio de Janeiro: Casa da Palavra, 2002, p. 13-59.

BRITTO, F. D., DRUMMOND. W. (Eds.). Experiências metodológicas para a compreensão da complexidade da cidade contemporânea. Salvador: EDUFBA, 2015. JANZER, C. L.; WEINSTEIN, L. S. Social Design and Neocolonialism. In Design and Culture, v. 6, nํㅜ 3, 2014, p. 327-343.

JORDAN, T. Activism! Direct Action. Hacktivism and the Future Society. London: Reaktion Books Ltd., 2002.

JÚDICE, A. C. B; JÚDICE, M. O. Thoughts and reflections on social design. A significant field of design. In MIETTINEN, S. (Ed.) Design your action. Social design in practise. Helsinki: University of Art and Design Helsinki, 2007, p. 44-53.

JULIER, G. From Design Culture to Design Activism. In Design and Culture, v.5, № 2, p. 212-236, july 2013, London: Bloomsbury, 2013. 
Political Economies of Design Activism and the Public Sector. In Proceedings

of Nordes 2011: Making Design Matter conference, Aalto University, Helsinki, 2011.

KJÆRSGAARD, M.; OTTO, T. Anthropological Fieldwork and Designing Potentials. In:

GUNN, W., DONOVAN, J. (Eds). Design and Anthropology. Farnham: Ashgate, 2012, p. 177-192.

KOSKINEN, I.; ZIMMERMAN, J.; BINDER, T.; REDSTROM, J.; WENSVEEN, S. Design

Research Through Practice: From the Lab, Field and Showroom. Elsevier: Morgan

Kaufmann, 2011

LATOUR, B. Reassembling the Social: an introduction to actor-network-theory. New York: Oxford University Press, 2005.

A esperança de Pandora: ensaios sobre a realidade dos estudos científicos.

Bauru, SP: EDUSC, 2001.

Networks, Societies, Spheres: Reflections of an Actor-network Theorist.

Keynote Lecture, Annenberg School of Design, Seminar on Network Theories, February 2010, published in the International Journal of Communication special issue edited by Manuel Castells, v. 5, 2011, p. 796-810. Disponível em: < http://ijoc.org/index.php/ijoc/ article/viewFile/1094/558>. Acesso em: 18 Mai. 2017.

A Cautious Prometheus? A Few Steps Toward a Philosophy of Design (With Special Attention to Peter Sloterdijk). In: HACKNE, F.; GLYNNE, J.; MINTO, V. (eds.). Proceedings of the 2008 Annual International Conference of the Design History Society. Falmouth, 3-6 September 2009, e-books, Universal Publishers, p. 2-10, 2009.

LENSKJOLD, T. U.; OLANDER, S.; HALSE, J. Minor Design Activism: Prompting Change from Within. In: Design Issues, v.31, no 4, Autumn 2015, p. 67-78, Cambridge: MIT Press, 2015. MAGALHÃES, A. O que o design industrial pode fazer pelo país? In: Revista Arcos, Rio de Janeiro. V.1, 1998, p 8-12. Disponível em: < http://www.esdi.uerj.br/sobrearcos/artigos/ documento_aloisio(8a13).pdf>. Acesso em: 20 de Jan. 2017.

.; LEITE, J. de S. (org.). Encontros: Aloisio Magalhães. Rio de Janeiro: Beco do Azougue, 2014 .

MALINOWSKI, B. Argonautas do Pacífico Ocidental. In CASTRO, C. Textos básicos de antropologia: cem anos de tradição: Boas, Malinowski, Lévi-Strauss e outros. Rio de Janeiro: Zahar, 2016, p. 94-123.

MANZINI, E. Design, when everybody designs: an introduction to design for social innovation. Cambridge: MIT Press, 2015.

. Design para inovação social e sustentabilidade. Cadernos do Grupo de Altos Estudos, Programa de Engenharia de Produção da Coppe/UFRJ, Rio de Janeiro, vol. 1, 2008. 
MARGOLIN, V. Design, the Future and the Human Spirit. In Design Issues, v.23, no 3, 2007, p. 4-15.

MARÉ VIVE. Página do facebook. Disponível em: < https://www.facebook.com/ Marevive/>. Acesso em: 8 Dez. 2017.

MARICATO, E. Metrópole na periferia do capitalismo: ilegalidade, desigualdade e violência. São Paulo: Hucitec, 1996.

MARKUSSEN, T. The Disruptive Aesthetics of Design Activim: Enacting Design Between Art and Politics. In: Design Issues, Vol. 29, N. 1, p. 38-50, 2013.

MAUSS, M. Sociologia e antropologia. São Paulo: Cosac Naify, 2003, p. 399-422.

MEHROTRA, R. Negotiating the Static and Kinetic Cities. The Emergent Urbanism of Mumbai. In: Other Cities, Other Worlds. Urban Imaginaries in a Globalizing Age. Huyssen, A. Durham and London: Duke University Press, 2008.

Working in Bombay: The City as Generator of Practice. In Anytime, June, 1998, p. 64-69. Disponível em: <http://www.rmaarchitects.com/essays/working-inbombay.pdf> Acesso em 13 Nov. 2017.

MICHAELIS. Página do dicionário Michaelis. 2018. Disponível em: < http://michaelis.uol. com.br/> Acesso em: 16 Jan. 2018.

MIETTINEN, S. (Ed.) Design your action. Social design in practise. Helsinki: University of Art and Design Helsinki, 2007.

MOLLENHAUER, $K$. The design Project as a political act and design policy as a civil action. The case of Chile. In MIETTINEN, S. (Ed.) Design your action. Social design in practise. Helsinki: University of Art and Design Helsinki, 2007, p. 32-41.

MONTUORI, B. F. Origens e concepção de um curso de design para contextos reais na PUC-Rio: a primeira identidade. In: BRAGA, M. C. da; FERREIRA, E. C. K. (Orgs). Histórias do Design no Brasil. São Paulo: Annablume, 2017, p. 79-99.

.., Rosa, M., Santos, M. C. L. Design by means of citizen activism: three cases illustrated by the action of Coletivo Maré, Rio de Janeiro, Brazil. In The Design Journal, 20:sup1, S2973-S2990.

MUDA MARÉ - EDUCAÇÃO AMBIENTAL E AGRICULTURA URBANA. Blog do projeto online e página do facebook. Disponível em: < http://mudamare.blogspot.com. br/2011/05/o-que-e-esse-projeto.html?view=sidebar> e < https://www.facebook.com/ mudamare/>. Acesso em: 12 de Jan. 2017.

NETO, C. C.; CASTELLO-BRANCO, L. R. R. Use of Science and technology to redesign. A society aiming at eliminating poverty. In MIETTINEN, S. (Ed.) Design your action. Social 
design in practise. Helsinki: University of Art and Design Helsinki, 2007, p. 42-43.

NIEDDERER, K. Mindful design as a driver for social behaviour change. Proceedings of the IASDR Conference 2013. Tokyo, Japan: IASDR, 2013

Designing mindful interaction: The category of the performative object. In

Design Issues, v.23, nำ 1, 2007, p. 3-17.

NÓBREGA JUNIOR, E. D.; BELFORT, M. C. e S.; RIBEIRO, P. Memória e identidade dos moradores de Nova Holanda. Rio de Janeiro: Redes da Maré, 2012.

OBSERVATÓRIO DE FAVELAS. Página web do Observatório de Favelas, 2018. Disponível em: <http://observatoriodefavelas.org.br/>. Acesso em: 10 de fev. 2018.

OLABI MAKESPACE. Página Web da organização. Disponível em: < https://www.olabi. org.br/>. Acesso em: 5 Jan. 2018.

QUEIROGA, E. F. Dimensões públicas do espaço contemporâneo: resistências e transformações de territórios, paisagens e lugares urbanos brasileiros. 2012, 284p. Tese (Livre Docência - Área de Concentração: Paisagem e Ambiente) - Faculdade de Arquitetura e Urbanismo da USP (FAU/USP), 2012.

PASTERNAK, S. T. São Paulo e suas favelas. - Revista Pós 19. Revista do Programa de pós graduação em Arquitetura e Urbanismo da FAU-USP, vol. 27, nำ19, 2006, jun., p.176-197.

Project for Public Spaces (PPS). Página oficial da organização. Disponível em: <http:// publicworkshop.us/>. Acesso em: 18 Mai. 2017.

RANCIÈRE, J. O mestre ignorante: cinco lições sobre a emancipação intelectual. Belo Horizonte: Autêntica, 2002.

REDES DE DESENVOLVIMENTO DA MARÉ. 2018. Página oficial da organização. Disponível em: < http://redesdamare.org.br/>. Acesso em: 8 Jan. 2018. . Guia de Ruas da Maré 2014. Rio de Janeiro: Redes de Desenvolvimento da Maré, 2014. Disponível em: <http://redesdamare.org.br/wp-content/uploads/2014/05/ GuiaMare_26mai.pdf>. Acesso em: 20 Jan. 2017.

Nenhum a menos... e muitos esforços a mais! A experiência de inclusão escolar de crianças e jovens do bairro da Maré, no Rio de Janeiro'. Rio de Janeiro: Redes de Desenvolvimento da Maré, 2008. Disponível em: <http://redesdamare.org.br/blog/ educacao-projetos/nenhum-a-menos-e-muitos-esforcos-mais/>. Acesso em: 22 de Jul. 2017.

REDSTRÖM, J. Introduction: Defining Moments. In: GUNN, W., DONOVAN, J. (Orgs). Design and Anthropology, p. 83-100, Farnham: Ashgate, 2012.

RITTEL, H.W.J.; WEBBER, M. M. Dilemmas in a general theory of planning. In Policy Sciences, Vol. 4, N.4, 1973, p. 155-169. 
RIZEK, C. S. Gestão da cidade/ gestão diferencial da vida/ confinamento e Moralização. In JACQUES, P. B., BRITTO, F. D., DRUMMOND. W. (Eds.). Experiências metodológicas para a compreensão da complexidade da cidade contemporânea. Salvador: EDUFBA, 2015.

ROSA, M. L. From modern infrastructures to operational networks. The qualification of local space at existing large scale utility infrastructure: a method for reading communitydriven initiatives. The case of São Paulo. 2015, 350 f. (Phd Thesis) - Universidade Técnica de Munique, Munique, 2015.

Microplanejamento práticas urbanas criativas. São Paulo: Cultura, 2011. WEILAND, U. E. Co-designing the City: Architecture + Informal

Intelligence. São Paulo: Meli Melo Press, 2017. .; WEILAND, U. E. Handmade urbanism. Berlin: Jovis, 2013.

RUDOFSKY, B. Architecture without architects. New York: Museum of Modern Art, 1964. SANDERS, E. B. N.; STAPPERS, P. J. Co-creation and the new landscapes of design. In Co-design, v. 4, ํㅡ 1, 2008, p. 5-18.

SILVA, J. de S. e. As Unidades Policiais Pacificadoras e os novos desafios para as favelas cariocas. Artigo publicado no acervo de publicações do Observatório de Favelas. Disponível em: <http://observatoriodefavelas.org.br/wp-content/uploads/2013/o6/ Aspectos-humanos-das-favelas-cariocas.pdf>. Acesso em: 17 de Mai. 2017.

SANTOS, C. R. dos. Entre o reconhecimento e a estigmatização da favela: um caso sobre a regularização do Morro do Timbau. 2015, 118f. Dissertação (Mestrado) - Universidade do Estado do Rio de Janeiro, Faculdade de Direito, 2015

SANTOS, M. C. L. Cidades de plástico e papelão: o habitat informal dos moradores de rua em São Paulo, Los Angeles e Tóquio. Tese (Livre-Docência). FAU-USP, São Paulo, 2003.

SANTOS, M. Da totalidade ao lugar. São Paulo: Edusp, 2014

SEN, A. Desenvolvimento como liberdade. São Paulo: Companhia das Letras, 2010.

SENNETT, R. O artífice. Rio de Janeiro: Record, $2013 a$.

Books, 2013b.

Together: the rituals, pleasures \& politics of cooperation. London: Penguin

SILVA, E. S. Testemunhos da Maré. Rio de Janeiro: Mórula, 2015.

SILVA, C. R. R. da. Maré: a invenção de um bairro. 2006, 238f. Dissertação (Mestrado Profissionalizante em Bens Culturais e Projetos Sociais) - Fundação Getúlio Vargas, Centro de Pesquisa e Documentação de História Contemporânea do Brasil (CPDOC), Rio de Janeiro, 2006. 
SIQUEIRA, P.; LIMA, T. S. "Ser afetado", de Jeanne Favret-Saada. Cadernos de campo, no 13, p. 155-161, 2005. Disponível em: <http://www.revistas.usp.br/cadernosdecampo/ article/viewFile/50263/54376>. Acesso em:18 Jan. 2017.

SMITH, R. C.; VANGKILDE, K. T.; KJAERSGAARD; OTTO, T.; HALSE, J.; BINDER, T.

Design Anthropological Futures. London; New York: Bloomsbury, 2016.

SPIVAK, G. C. Can the subaltern spealk? Reflections on the history of an idea. New York: Columbia University Press, 2010.

THORPE, A. Defining Design as Activism. Artigo submetido ao Journal of Architectural Education, 2011. Disponível em: http://designactivism.net/wp-content/uploads/2011/05/ Thorpe-definingdesignactivism.pdf. Acesso em: 18 Nov. 2016.

TRAVESSIAS 5: EMERGÊNCIA. 2017. Página oficial do evento. Disponível em:< http://2017.travessias.org.br/>. Acesso em 15 Jan. 2018.

TUCKER, E. Micaella Pedros uses heat-shrunk plastic bottles to join furniture. Dezeen, 30, jun 2016. Disponível em: <https://www.dezeen.com/2016/06/30/micaella-pedrosroyal-college-of-art-graduate-showrca-joining-bottles-wood-furniture-recycled-plastic/ $>$. Acesso em: 10 Mai. 2017.

VARELLA, D.; BERTAZZO, I.; JACQUES, P. B. Maré: vida na favela. Rio de Janeiro: Casa da Palavra, 2002.

VAZ, L. F. (Org.). História dos bairros da Maré: espaço, tempo e vida cotidiano Complexo da Maré. Rio de Janeiro: UFRJ, 1994.

X Bienal de Arquitetura de São Paulo. Página oficial do evento. Disponível em: <https:// www.facebook.com/xbienaldearquitetura/>. Acesso em: 10 Nov. 2016.

WAGNER, R. A Invenção da Cultura. São Paulo: Cosac Naify, 2015.

WISNIK, G; NOBRE, L.; NOBRE, A. L. Cidade: modos de fazer, modos de usar. Drops, São Paulo, ano 14, n. 074.06, Vitruvius, nov. 2013 <http://www.vitruvius.com.br/revistas/ $\mathrm{read} /$ drops/14.074/4962>.

WOLFRUM, S.; BRANDIS, N. F. v. Performative Urbanism. Generating and Designing Urban Space. Berlin: Jovis, 2015.

ZALUAR, A., ALVITO, M. (Eds). Um século de favela. Rio de Janeiro: FGV, 2006. 
11aㅡ Bienal de Arquitetura de São Paulo. Página oficial do evento. Disponível em: <https:// www.11bienaldearquitetura.org.br/>. Acesso em 28 de Nov. 2017.

\section{Entrevistas realizada}

Entrevista realizada com José Luiz Mendes Ripper, em 7 de maio de 2016, na cidade do Rio de Janeiro, com duas horas de duração.

Entrevista realizada com José Luiz Mendes Ripper, em 3 de junho de 2016, na cidade do Rio de Janeiro, com três horas de duração.

Entrevista realizada com José Luiz Mendes Ripper, em 19 de julho de 2016, na cidade do Rio de Janeiro, com uma hora e meia de duração.

Entrevista realizada com Chiara Del Gaudio, em 22 de setembro de 2017, virtual por Skype, com uma hora e meia de duração.

Entrevista realizada com Chiara Del Gaudio, em 2 de outubro de 2017, virtual por Skype, com uma hora e meia de duração. 
